\title{
ESTUDO CEFALOMÉTRICO COMPARATIVO DAS \\ ALTERAÇÕES DECORRENTES DO USO DE DOIS TIPOS DE APARELHOS EXTRABUCAIS EM JOVENS COM MÁ OCLUSÃO DE CLASSE II, $1^{\text {a }}$ DIVISÃO DE ANGLE
}

RAFAEL PINELLI HENRIQUES

Dissertação apresentada à
Faculdade de Odontologia de
Bauru, da Universidade de São
Paulo, como parte dos requisitos
para obtenção do título de Mestre
em Odontologia, área de
Ortodontia.

(Edição Revisada) 


\title{
ESTUDO CEFALOMÉTRICO COMPARATIVO DAS \\ ALTERAÇÕES DECORRENTES DO USO DE DOIS TIPOS DE APARELHOS EXTRABUCAIS EM JOVENS COM MÁ OCLUSÃO DE CLASSE II, $1^{\text {a }}$ DIVISÃO DE ANGLE
}

\section{RAFAEL PINELLI HENRIQUES}

\author{
Dissertação apresentada à Faculdade \\ de Odontologia de Bauru, da \\ Universidade de São Paulo, como \\ parte dos requisitos para obtenção do \\ título de Mestre em Odontologia, área \\ de Ortodontia.
}

Orientador:

Prof. Dr. Renato Rodrigues de Almeida (Edição Revisada) 


\begin{tabular}{|c|c|}
\hline \multirow[b]{2}{*}{ H395e } & Henriques, Rafael Pinelli \\
\hline & 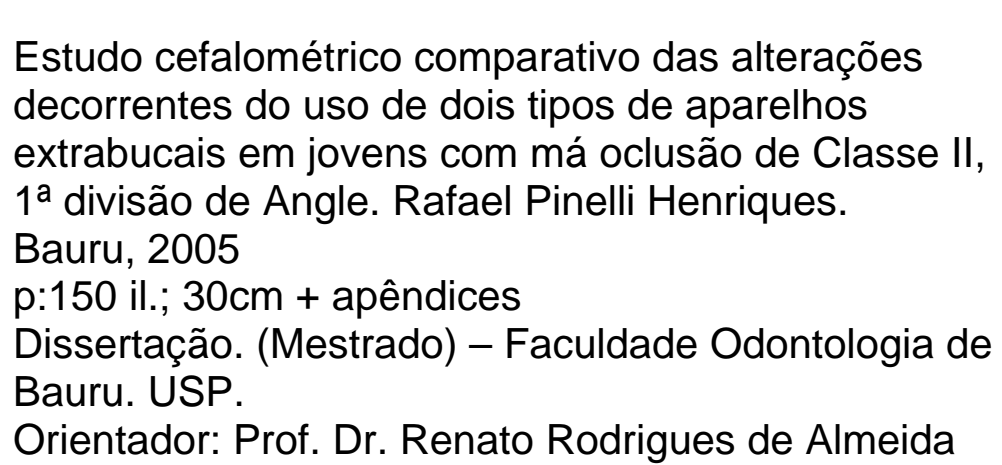 \\
\hline
\end{tabular}

Autorizo, exclusivamente para fins acadêmicos e científicos, a reprodução total ou parcial desta tese, por processos fotocopiadores e outros meios eletrônicos.

Assinatura do autor:

Data:

Projeto de pesquisa aprovado pelo comitê de ética em pesquisa da Faculdade de Odontologia de Bauru, Universidade de São Paulo, na reunião do dia 30 de outubro de 2002. 


\section{RAFAEL PINELLI HENRIQUES}

28 de junho de 1980

$1998-2002$

$2001-2002$

2003-2004

Associações
Nascimento

Bauru - S.P.

Curso de odontologia na faculdade de odontologia da Universidade do Sagrado Coração.

Curso de aperfeiçoamento em ortodontia na ACOPEN (Assessoria e Consultoria em Ortodontia Pesquisa e Ensino).

Curso de Pós-Graduação em Ortodontia, ao nível de Mestrado, na Faculdade de Odontologia de Bauru da Universidade de São Paulo.

APEO - Associação Paulista de Especialistas em Ortodontia e Ortopedia Facial. APCD - Assiciação Paulista dos Cirurgiões - Dentistas.

SBPqO - Sociedade Brasileira de Pesquisa Odontológica. 


\section{SINCEROS AGRADECIMENTOS}

\section{PRIMEIRAMENTE À DEUS}

Minha eterna gratidão ao pai do universo, ao centro da vida e da luz, da felicidade e compaixão.

Sem o Senhor nada seria possível, nada seria concretizado, nada seria alcançado.

Obrigado por sempre me acompanhar, principalmente nesta jornada um pouco conturbada, obrigado por me dar saúde, uma ótima família e ótimos amigos, para junto com - Senhor poder superar os desafios que a vida nos proporciona.

\section{OBRIGADO POR TUDO SENHOR, VOU ESTAR ETERNAMENTE AO SEU LADO}




\section{DEDICATÓRIA}

\section{A MINHA GRANDE FAMÍLIA}

Grande não só no nome, mas nas atitudes, dedico este trabalho primeiramente à todos vocês da minha família, que acompanharam-me diariamente, e estiveram presentes absolutamente em todos os momentos de desenvolvimento deste trabalho, sempre me apoiando $e$ orientando, mostrando os caminhos sólidos e mais claros, considero como família não somente as pessoas interligadas pelo sangue, mas todas aquelas que gostam da nossa companhia e nos apóiam, principalmente nos momentos difíceis.

\section{A minha amada e eterna esposa}

Pô, muito obrigado por todo o apoio e dedicação intensa em todos os momentos da minha vida, obrigado por estar 
sempre presente, principalmente nos momentos mais difíceis e sempre me apoiar, em todos os sentidos. Obrigado também pelas noites mal dormidas que dedicou à mim, e por alguns finais de semana que teve que deixar de ir viajar ou mesmo sair em uma balada mais forte, $e$ obrigado por ouvir sempre sem reclamar a tão dita frase:

"Não vou fazer isto porque tenho que fazer a minha tese".

Minha eterna gratidão

\section{Aos meus pais amados}

Fernando e Arlette, muito obrigado primeiramente por ter me dado a vida, depois obrigado por sempre terem me apoiado, sempre com muito carinho, respeito e amor, entendendo as dificuldades e imposições da vida, sempre dando a volta por cima em momentos difíceis com palavras doces e tranqüilas, apresentando a vida como sendo algo não tão difícil, e encarando as coisas com naturalidade e honestidade.

Minha eterna gratidão 


\section{A minha irmã}

Fernanda, por também sempre ter me apoiado $e$ incentivado, obrigado também por estar sempre presente em todos os principais momentos da minha vida, e pela alegria contagiante.

\section{Ao meu sogro e a minha sogra}

Val e Paulinho, que sempre me incentivaram, ofertando palavras e ações puras, aceitando e convivendo comigo em todos os momentos, e obrigado principalmente pela amizade que existe entre nós, não somente de sogro e sogra, mas como pai e mãe. Obrigado.

Aos meus cunhados, cunhadas e sobrinho

Neto, Thiago, Gustavo, Bianca, Lidiane, Fernanda e João Vitor, muito obrigado também por sempre me apoiar, e 
estar conosco em momentos alegres, fazendo com que nossas vidas tornem-se mais saudáveis e felizes.

Obrigado.

\section{Aos meus tios e primos}

Muito obrigado por todo o apoio sempre concedido, direta ou indiretamente, Tio Ivan, Tia Arlene, Fabrício,

Danilo e Liciane (e seus namorados), pelo constante apoio, Tio Ayres, Tia Eliane, Ariane, Sarita e Rebeca pela companhia sempre agradável, e aos meus tios Carlos e Ilídia e meus primos Adriana e Carlos (Dú).

\section{Aos meus Avós}

Que mesmo não presente e atuante palpavelmente, com certeza em todos os momentos me abençoaram e acompanharam todos os meus passos durante esta jornada. E ao Seu José e à Dona Laura, meus agradecimentos especiais. 


\section{Agradecimento Especial}

Ao meu pai, professor e mestre Dr. José Fernando Castanha Henriques, pelos ensinamentos não somente na vida transmitidos, mas como os prifissionais também ofertados. Obrigado por apoiar e mostrar os caminhos necessários para a conclusão deste trabalho, e obrigado também por estar presente em todos os momentos da minha vida.

\section{Agradecimento Especial}

Ao meu professor e orientador Dr. Renato Rodrigues de Almeida, por em todos os momentos demonstrar os caminhos corretos e específicos para a conclusão deste trabalho, e em todos os momentos mostrar-se disposto à ajudar, à colaborar, e além dos ensinamentos ortodônticos transmitidos, gostaria também de 
agradecer os ensinamentos de vida, mostrando sempre que para ser superior basta ser humilde.

\section{Agradecimento Especial}

Ao professor Dr. Guilherme Janson, coordenador do curso de pós-graduação ao nível de Mestrado, meu eterno agradecimento pelos ensinamentos constantemente transmitidos, e pela perseverança e determinação em todos os seus atos. Muito obrigado.

\section{Agradecimento Especial}

A Patrícia, aluna da próxima turma de mestrado, meu sincero agradecimento, principalmente com relação ao auxilio na parte estatística do trabalho, e à sua mãe, pelas orientações nas correções da língua portuguesa.

Agradecimento Especial 
Ao Professor Lauris, pelo auxílio incansável para a realização da estatística da pesquisa.

\section{Agradecimentos}

À todos os professores da Ortodontia e suas famílias, as quais me viram crescer e me conhecem profundamente, meu muito obrigado, Dr. Fernando (meu pai), e Arlette (minha mãe), Dr. Marcos (ou tio Marcos nos momentos extra-faculdade), Tia Lene, Dr. Arnaldo (ou tio Arnaldo), Tia Célia, Dr. Guilherme, Dr. Décio, Dona Thereza, Dr. Renato e Tia Odete, meus sinceros agradecimentos à todos os momentos de dedicação e apoio.

Aos filhos e netos dos professores da Ortodontia, que são meus amigos, Karina, Daniel, Celinha, Veridiana, Luciana, Maria Fernanda, Renata e Márcio, e suas famílias, meu muito obrigado pelo apoio constante, amizade e cordialidade sempre presentes. 


\section{À Professora Dra. Maria Fidela de Lima Navarro,}

Diretora da Faculdade de Odontologia de Bauru, e ao Professor Dr. José Carlos Pereira, Presidente da Comissão de Pós-Graduação da Faculdade de Odontologia de Bauru, pela oportunidade que me foi concedida.

A todos os meus amigos, pois são eles que nos dão forças para superar os desafios que a vida nos proporciona, em especial ao meu amigo Raphael Panichi e sua esposa Simone, Fernando Pedrin e sua esposa Renata, Walter Baptista e sua esposa Ana Lúcia e Fabrício Valarelli e Thaís, Wagner Baptista e Valéria, Fábio e Cilmara, Ricardo e Mayra, por sempre estarem presentes e dando todo o apoio do mundo necessário.

Aos amigos do curso de Mestrado, Renata, Sérgio, Fernando Ozzy, Fernando Pedrin, Lívia, Paula, Alexandre Jiraya, Kelly, Marcos Janson, Marcus Crepaldi, Adriana Crepaldi e Darwin, e seus maridos, namorados, esposas e namoradas, pelo apoio constante, amizade $e$ companheirismo demonstrado durante todo o trajeto. 
Aos alunos da ACOPEN e do curso de Ortodontia Preventiva da APCD pelo apoio, companheirismo e reconhecimento.

Aos amigos da turma de Doutorado, Fabrício, Karina Freitas, Karina Lima, Celinha, José Eduardo, Fernanda, Rejane, Rodrigo e Leniana, pela amizade e apoio ofertado.

Aos funcionários da Disciplina de Ortodontia, Cristina, Neide, Thiago, Sérgio, Verinha e Tia Maria, muito obrigado pelo companheirismo e amizade constante.

À equipe da ACOPEN, Sônia, César, Luciana, Daniel Bonné e Dona Adélia, pela amizade, companheirismo e dedicação prestada, meu muito obrigado.

À equipe do SDO, Fabrício, Waltinho, Wagner, Leia, Valéria, por proporcionarem momentos agradáveis ao trabalho e pelo companheirismo, obrigado. 


\section{À equipe do $\mathrm{COPH}$, por sempre demonstrar cordialidade e companheirismo, Simone, Carol, Renata, Cris e aos dentistas que lá trabalham, Romeo, Fabrício, Simone, Marcelo, Thais, Vivian, Mônica, Chiquinho e Valéria, pelo constante apoio, meu muito obrigado.}

Aos funcionários e colegas da $A P C D$, pela presença alegre e constante, obrigado.

À todos os funcionários da Biblioteca, que sempre prestaram todas as suas dedicações e orientações possíveis, muito obrigado.

Aos funcionários da pós-graduação, pela sempre presente ajuda e dedicação.

E como dizem: $O$ cão é o melhor amigo do homem, portanto não poderia esquecer do Jack, por sempre ouvir tudo sem dizer nada. 
E a todos aqueles que colaboraram direta ou indiretamente para a concretização deste estudo, $e$ agradeço também alguém que eventualmente possa não ter citado.

À CAPES pela concessão da bolsa de estudo que fez com que este trabalho pode ser desenvolvido. 


\section{SUMÁRIO}

LISTA DE FIGURAS

xviii

LISTA DE TABELAS

$\mathbf{x x}$

RESUMO

xxii

1 INTRODUÇÃO

2 REVISÃO DE LITERATURA 6

2.1- Características da má oclusão de Classe II, $1^{\text {a }}$ divisão de

Angle;

2.1.1- Conclusão dos artigos relacionados às

características da má oclusão de Classe II, $1^{\mathrm{a}}$

divisão 25

2.2- Tratamento da má oclusão de Classe II, $1^{\text {a }}$ divisão com o uso do aparelho extrabucal conjugado (splint maxilar) 26

2.2.1- Conclusão dos artigos referentes ao tratamento da má oclusão de Classe II, $1^{\mathrm{a}}$ divisão com o aparelho extrabucal conjugado 38

2.3- Tratamento da má oclusão de Classe II, $1^{\text {a }}$ divisão com o uso do aparelho extrabucal de tração occipital (IHG) 39

2.3.1- Conclusões dos trabalhos analisados pertinentes ao aparelho extrabucal de tração occipital 57

3 PROPOSIÇÃO 59

4 MATERIAL E MÉTODOS 61

4.1 Material 61

4.1.1 Obtenção da amostra 61

4.1.2 Descrição dos aparelhos utilizados nos grupos experimentais 63

4.1.2.1 Aparelho extrabucal conjugado (splint maxilar) 63

4.1.2.2 Aparelho extrabucal de tração occipital (IHG) 65 
4.2 Métodos

4.2.1 Radiografias Cefalométricas 67

4.2.2 Elaboração do cefalograma 67

4.2.2.1 Delimitação das estruturas dentoesqueléticas e do perfil tegumentar 68

4.2.2.2 Demarcação dos pontos cefalométricos de referência 70

4.2.2.3 Planos e linhas de referência 74

4.2.2.4 Mensuração das grandezas angulares e lineares 76

4.3 Análise Estatística 80

5 RESULTADOS 82

6 DISCUSSÃO 109

7 CONCLUSÕES 134

REFERÊNCIAS BIBLIOGRÁFICAS 137

ABSTRACT 149

APÊNDICE 151 


\section{LISTA DE FIGURAS}

FIGURA A AEB conjugado - vista oclusal superior 64

FIGURA B Paciente com o aparelho extrabucal conjugado 64

FIGURA C Aparelho IHG - vista oclusal superior 66

FIGURA D Paciente com o aparelho IHG 66

FIGURA 1 Desenho anatômico das estruturas dentoesqueléticas e do perfil tegumentar 71

FIGURA 2 Pontos cefalométricos utilizados 73

FIGURA 3 Planos e linhas de referência___ 75

FIGURA 4 Grandezas angulares__ 77

FIGURA 5 Grandezas lineares __ 79

FIGURA 6 Alterações do ângulo SNA nos três grupos ___ 96

FIGURA 7 Alterações da medida FHP-A nos três grupos____ 97

FIGURA 8 Alterações da medida Co-A nos três grupos ___ 97

FIGURA 9 Alterações da medida Co-Gn nos três grupos____ 98

FIGURA 10 Alterações do ângulo SNB nos três grupos ___ 98

FIGURA 11 Alterações do ângulo ANB nos três grupos ___ 99

FIGURA 12 Alterações da medida AFAl nos três grupos ___ 99

FIGURA 13 Alterações do ângulo SN.GoMe nos três grupos____ 100

FIGURA 14 Alterações do ângulo SN.PP nos três grupos ___ 100

FIGURA 15 Alterações do ângulo FRANK.Plo nos três grupos ___ 101

FIGURA 16 Alterações do ângulo PP.GoMe nos três grupos ____ 101

FIGURA 17 Alterações do ângulo FMA nos três grupos___ 102

FIGURA 18 Alterações do ângulo Ar.GoMe nos três grupos ___ 102

FIGURA 19 Alterações da medida 1-PP nos três grupos ___ 103

FIGURA 20 Alterações do ângulo 1.NA nos três grupos ___ 103

FIGURA 21 Alterações da medida FHP-DISTAL $\underline{6}$ nos três grupos___ 104

FIGURA 22 Alterações da medida FHP-ÁPICE $\underline{6}$ nos três grupos ___ 104

FIGURA 23 Alterações da medida $\underline{6}$-PP nos três grupos____ 105

FIGURA 24 Alterações da medida $\overline{\mathbf{6}}$-GoMe nos três grupos ___ 105

FIGURA 25 Alterações da medida $\overline{\mathbf{1}}$-GoMe nos três grupos ___ 106 
FIGURA 26 Alterações da medida Ls-E nos três grupos 106

FIGURA 27 Alterações da medida Li-E nos três grupos 107

FIGURA 28 Alteração do ângulo nasolabial nos três grupos 107

FIGURA 29 Alterações do ângulo SNA nos três grupos 113

FIGURA 30 Alterações da medida FHP-A nos três grupos 114

FIGURA 31 Alterações da medida Co-A nos três grupos 115

FIGURA 32 Alterações do ângulo SNB nos três grupos 117

FIGURA 33 Alterações da medida Co-Gn nos três grupos 117

FIGURA 34 Alterações do ângulo 1.NA nos três grupos 118

FIGURA 35 Alterações da medida 1-PP nos três grupos 119

FIGURA 36 Alterações da medida $\underline{6}$-PP nos três grupos 120

FIGURA 37 Alterações da medida FHP-ÁPICE $\underline{6}$ nos três grupos 120

FIGURA 38 Alterações da medida FHP-DISTAL $\underline{6}$ nos três grupos 121

FIGURA 39 Alterações da medida $\overline{1}$-GoMe nos três grupos 121

FIGURA 40 Alterações da medida $\overline{\mathbf{6}}$-GoMe nos três grupos 122

FIGURA 41 Alterações do ângulo ANB nos três grupos 122

FIGURA 42 Alterações da medida AFAl nos três grupos 124

FIGURA 43 Alteração do ângulo nasolabial nos três grupos 124

FIGURA 44 Alterações da medida Ls-E nos três grupos 125

FIGURA 45 Alterações da medida Li-E nos três grupos 126

FIGURA 46 Alterações da medida FHP-DISTAL nos três grupos 126

FIGURA 47 Alterações da medida -GoMe nos três grupos. 127

FIGURA 48 Alteração da medida -GoMe nos três grupos. 128

FIGURA 49 Alteração do ângulo nasolabial nos três grupos. 128

FIGURA 50 Alteração da medida Ls-E nos três grupos. 129

FIGURA 51 Alteração da medida Li-E nos três grupos. 129 


\section{LISTA DE TABELAS}

TABELA 1 Análise de variância entre as médias das idades iniciais e finais dos jovens nos 3 grupos e do tempo médio de tratamento. 82

TABELA 2 Teste de Tukey para a média das idades iniciais. 83

TABELA 3 Cálculo do erro do método intra-examinador. 85

TABELA 4 Análise de variância entre os 3 grupos dos valores médios das medidas iniciais. 87

TABELA 5 Teste de Tukey entre os grupos 1 e 2 para a comparação das medidas iniciais. 88

TABELA 6 Teste de Tukey entre os grupos 1 e 3 para a comparação das medidas iniciais. 89

TABELA 7 Teste de Tukey entre os grupos 2 e 3 para a comparação das medidas iniciais. 90

TABELA 8 Análise de variância entre os 3 grupos das diferenças das médias das alterações finais e iniciais. 92

TABELA 9 Teste de Tukey entre os grupos 1 e 2 para a comparação das médias das alterações. 93

TABELA 10 Teste de Tukey entre os grupos 1 e 3 para a comparação das médias das alterações. 94

TABELA 11 Teste de Tukey entre os grupos 2 e 3 para a comparação das médias das alterações. 95 
Resumo 


\section{RESUMO}

O presente trabalho propôs avaliar cefalometricamente as alterações dentárias, esqueléticas e tegumentares em jovens com má oclusão de Classe II, $1^{\text {a }}$ divisão tratados com o aparelho extrabucal conjugado (splint maxilar) e com o aparelho extrabucal de tração occipital (IHG). Os grupos experimentais foram comparados à um grupo controle, que apresentavam a mesma má oclusão, pareados pelo gênero, idade e tempo de observação. Um total de 150 telerradiografias em norma lateral de 75 jovens fizeram parte da amostra, divididos em três grupos de 25. Os jovens do grupo 1 foram tratados com o aparelho extrabucal conjugado, apresentaram uma idade média inicial de 9,71 anos e foram observados pelo período médio de 1,41 anos. O grupo 2, foi submetido ao tratamento utilizando o aparelho extrabucal de tração occipital (IHG), com idade média inicial de 10,51 anos e acompanhados por um período de 1,32 anos. Os jovens do grupo 3 foram mantidos como controle, apresentaram uma idade média inicial de 10,06 anos e foram observados pelo período médio de 1,35 anos. Todas as mensurações foram submetidas à análise estatística. A análise dos resultados mostrou que o deslocamento anterior da maxila foi restringido significantemente nos grupos experimentais. $A$ mandíbula apresentou um aumento de seu crescimento efetivo (Co-Gn) estatisticamente significante no grupo tratado com o aparelho AEB conjugado. A relação maxilomandibular melhorou significantemente nos grupos tratados. Em relação às alterações dentoalveolares superiores, o grupo tratado com o aparelho AEB conjugado apresentou uma inclinação para lingual dos incisivos superiores enquanto os outros 2 grupos apresentaram uma discreta inclinação para vestibular destes dentes. A movimentação de distalização dos molares superiores foi significante para os grupos experimentais. A movimentação de extrusão dos molares inferiores mostrou também um resultado não significante entre os grupos. Com relação ao perfil tegumentar, constatou-se que o ângulo nasolabial não apresentou modificação pelo tratamento, assim como a posição espacial do lábio inferior. Já o lábio superior demonstrou uma maior retrusão 
nos grupos experimentais com diferença estatística significante. Desta maneira, verificou-se que ambos protocolos de tratamento propiciaram alterações esqueléticas, dentárias e tegumentares clinicamente relevantes para a correção da má oclusão de Classe II, $1^{\text {a }}$ divisão. 


\section{Introdução}




\section{INTRODUÇÃO}

O mau posicionamento dentário vem sendo discutido ao longo de muitos anos. Em 1899, Angle $^{11}$, na tentativa de simplificar a identificação das más oclusões, determinou três Classes distintas, mas sua classificação baseava-se principalmente nas posições dentoclusais e não considerava as discrepâncias nos sentidos vertical, horizontal e transversal (esqueléticas), e nem relacionava-as com as estruturas esqueléticas adjacentes. Desde as últimas décadas, sabe-se que a má oclusão de Classe II tem um envolvimento das bases ósseas no sentido sagital, vertical e transversal, caracterizada morfologicamente por uma discrepância maxilomandibular e por um relacionamento incorreto dos arcos dentários superior e inferior, ou ainda por uma combinação destes fatores.

A má oclusão de Classe II, não possui morfologia única que defina a estrutura facial, são variadas as relações horizontais e verticais, possuindo em comum, apenas a relação ântero-posterior dos arcos dentários. Esta relação pode variar desde uma retrusão mandibular, uma protrusão maxilar, ou até mesmo uma combinação de fatores, sendo o retrognatismo mandibular considerado como um dos maiores responsáveis por esta má oclusão ${ }^{90}$. A má oclusão é considerada esquelética quando há apenas o envolvimento das bases ósseas maxilares, e é determinada de dentária, quando apresenta puramente alterações dentoalveolares. Pode-se observar na maioria dos casos, que ocorre a combinação de fatores esqueléticos e dentários. A má oclusão de Classe II pode ainda estar combinada com uma função anormal dos lábios e de alguma forma de obstrução nasal e respiração bucal ${ }^{12}$.

A má oclusão de Classe II pode afetar as características faciais de diferentes maneiras, de acordo com a intensidade do overjet (sobressaliência) apresentado, e de sua interação com as estruturas adjacentes de tecidos moles, interferindo profundamente na aparência e auto-estima do paciente ${ }^{56,106,127,128}$. 
O tratamento da má oclusão de Classe II é amplamente estudado $^{3,6,16,50,78}$, devido principalmente ao grande número de pacientes que apresentam esta má oclusão, mostrando uma prevalência de 55\% dos pacientes que procuram tratamento ${ }^{54}$.

Os estudos cefalométricos atuais demonstram que os efeitos esqueléticos derivados de forças intrabucais são muito menos eficazes do que os ortodontistas acreditavam no início do século XX, e que a força extrabucal derivada dos aparelhos extrabucais permanecem imbatíveis $32,45,73,76,82,83,88,101,116$.

Com a sobreposição dos traçados, verifica-se que a correção ocorre como resultado do crescimento diferencial entre maxila e mandíbula. Entretanto há um questionamento com relação a este crescimento diferencial, questionando se ocorre com ou sem tratamento, portanto é necessário separar as mudanças decorrentes do tratamento, daquelas que ocorreriam apenas com o crescimento ${ }^{127}$.

O tratamento dos pacientes que apresentam a má oclusão de Classe II depende da idade em que encontram-se, do comprometimento estético e oclusal. A interceptação da má oclusão de Classe II constitui um assunto bastante comentado, sendo que destaca-se o tratamento em uma única fase (realizado com a ortodontia fixa) e em duas fases (realizado com aparelhos ortopédicos e fixos). Os aparelhos ortopédicos visam corrigir discrepâncias nos sentidos ântero-posterior e transversal, contribuindo portanto para a melhora na relação das bases apicais. O tratamento com aparelhos ortopédicos deve ser indicado para jovens na fase de crescimento e desenvolvimento craniofacial, com a finalidade de alterar espacialmente a forma e o posicionamento das bases ósseas, redirecionando o crescimento da maxila e liberando o crescimento da mandíbula.

São vários os aparelhos utilizados para interceptação e/ou correção destas más oclusões, com o intuito de obter uma oclusão funcional e esteticamente satisfatória. Estes aparelhos causam preocupações, como os 
efeitos que produzem, o método de ação, e o período mais indicado para a utilização, sendo que as alterações mais evidentes são o reposicionamento ântero-posterior das bases apicais, melhora da relação molar e redução do overjet. Com relação ao efeito obtido de restrição do crescimento anterior da maxila, promovida pelo $A E B$, há um consenso entre vários autores $3,5,35,53$ $63,64,6584,88,121$ de que este fato realmente é observado.

Perante estas considerações e devido às divergências de resultados entre os estudos encontrados e comentados, o objetivo deste trabalho concentra-se em avaliar cefalometricamente as alterações observadas no acompanhamento de um grupo de pacientes com má oclusão de Classe $\mathrm{II}_{1} 1^{\mathrm{a}}$ divisão, sem tratamento, comparando-o com outros dois grupos, um tratado com ancoragem extrabucal occipital (IHG), e outro tratado com aparelho removível conjugado a ancoragem extrabucal. O interesse em realizar estas comparações cefalométricas entre estes dois grupos tratados ortodonticamente, com um grupo sem tratamento ortodôntico, baseia-se no fato da pequena quantidade de pesquisas ${ }^{7,66,84,88,95,117}$ enfocando um grupo controle sem tratamento, que avaliem cefalometricamente os efeitos de diferentes terapias ortodônticas. 


\section{Revisão de Literatura}




\section{REVISÃO DE LITERATURA}

Em função da vasta gama de implicações relacionadas com o estudo do tratamento da má oclusão de Classe II, $1^{\text {a }}$ divisão de Angle com o uso do aparelho extrabucal conjugado (Splint Maxilar), e o uso do aparelho extrabucal de tração occipital (IHG), a revisão de literatura abordará o tema em tópicos:

2.1- Características da má oclusão de Classe II, $1^{\mathrm{a}}$ divisão de Angle;

2.1.1- Conclusão dos artigos relacionados às características da má oclusão de Classe II, $1^{\text {a }}$ divisão.

2.2- Tratamento da má oclusão de Classe II, $1^{\text {a }}$ divisão com o uso do aparelho extrabucal conjugado (splint maxilar);

2.2.1- Conclusão dos artigos referentes ao tratamento da má oclusão de Classe II, $1^{\mathrm{a}}$ divisão com o aparelho extrabucal conjugado.

2.3- Tratamento da má oclusão de Classe $\mathrm{II}, 1^{\text {aa }}$ divisão com o uso do aparelho extrabucal de tração occipital (IHG);

2.3.1- Conclusões dos trabalhos analisados pertinentes ao aparelho extrabucal de tração occipital.

\section{1 - CARACTERÍSTICAS DA MÁ OCLUSÃO DE CLASSE II, 1ª DIVISÃO DE}

\section{ANGLE}

Sempre houve interesse em atribuir e especificar medidas padronizadas para as más oclusões, classificando-as. Com a evolução dos métodos de pesquisa e o aperfeiçoamento dos profissionais, maior atenção foi dada ao processo de crescimento e desenvolvimento, pois tornou-se indiscutível a decisiva participação desse fenômeno para o sucesso da maioria dos tratamentos ortodônticos, tanto do ponto de vista estético e funcional, como quanto à estabilidade.

Para avaliar as alterações decorrentes do crescimento de indivíduos com má oclusão de Classe II, $1^{\mathrm{a}}$ divisão e compará-las com as modificações 
advindas do seu tratamento, torna-se necessário conhecer pesquisas em relação às características que Ihe dão conformidade ao comportamento do seu crescimento e desenvolvimento e os estudos referentes ao seu tratamento.

A relação Classe II, $1^{\text {a }}$ divisão foi classificada primeiramente por ANGLE 11 , em 1899, quando publicou na revista "DENTAL COSMOS" o primeiro método científico para o diagnóstico e classificação das más oclusões que baseavam-se essencialmente nas posições dentoclusais, onde definiu que o primeiro molar superior era imutável em relação ao inferior, e a partir daí determinou os três tipos de más oclusões no sentido ântero-posterior. A classificação de Angle ${ }^{11}$ apresenta-se de maneira muito prática, mas não leva em consideração as discrepâncias nos sentidos vertical, horizontal e lateral, e nem as relaciona com as estruturas esqueléticas adjacentes. Foi definida por apresentar uma relação mesiodistal relativa deficiente dos arcos dentários, com todos os dentes inferiores ocluindo distalmente ao normal, produzindo uma desarmonia acentuada na região dos incisivos e nas linhas faciais. Nesta má oclusão, o arco superior apresenta-se atrésico e os incisivos superiores protruídos.

Em 1907, o mesmo pesquisador ${ }^{12}$ constatou que os casos de Classe II, $1^{\mathrm{a}}$ divisão, caracterizavam-se por apresentar uma relação distal da mandíbula em relação à maxila, e geralmente com tamanho menor. Afirmou também que a maxila apresentava-se maior que o normal e, freqüentemente atrésica, e os incisivos superiores encontravam-se vestibularizados e os inferiores lingualizados. Notou ainda que esta má olcusão encontrava-se na maioria das vezes acompanhada de uma função anormal dos lábios e de alguma forma de obstrução nasal e respiração bucal.

Após 15 anos, outro pesquisador, HELLMAN ${ }^{58}$, constatou que a mandíbula encontrava-se subdesenvolvida assim como a maxila, estudando também casos de Classe $\mathrm{II}, 1^{\mathrm{a}}$ divisão, complementando assim os estudos anteriores realizados por Angle ${ }^{11,12}$. 
Alguns anos após, em 1925, LUNDSTRÖM ${ }^{81}$ após revisar a literatura sobre a natureza da Classe II, observou a existência de um padrão esquelético de origem hereditária, que dificulta o tratamento ortodôntico, e um padrão dentário de fácil tratamento.

OPPENHEIM ${ }^{99}$, em 1936, concordando com as observações de HELLMAN $^{58}$ em 1922, enfocou que na maioria das más oclusões de Classe II, ocorre deficiência no desenvolvimento mandibular. Em seu estudo comparou medidas antropométricas de 18 crânios com características normais e 18 crânios exibindo má olcusão de Classe II. Concluiu que a Classe II não caracterizava-se por um excesso de crescimento para anterior da maxila, verificando pelo ponto próstio, mas que na grande maioria dos casos de distoclusão, este ponto encontra-se posicionado posteriormente. Comentou também que o tratamento desta má oclusão deveria consistir no estímulo do crescimento e desenvolvimento mandibular.

ANDERSON $^{10}$, em 1946, apresentou um trabalho onde discutiu casos clínicos que apresentavam a má oclusão de Classe II, e demonstrou que em muitos deles a mandíbula apresentava-se bem posicionada, e não subdesenvolvida, sendo que a maxila apresentava-se protruída em relação à base do crânio, gerando uma distoclusão aparente dos molares inferiores e, desta forma, exigindo uma alteração no plano de tratamento.

DRELICH ${ }^{44}$, em 1948, estudou o padrão facial de 24 jovens com má olcusão de Classe II, $1^{\mathrm{a}}$ divisão e observou dentre outros fatores, que a mandíbula apresentava-se com seu comprimento diminuído, concretizando o apresentado por OPPENHEIM ${ }^{99}$, em 1936. Destacou também que o mento localizava-se mais para posterior e a base do crânio encontrava-se aumentada. Afirmou ainda que grande parte dos pacientes estudados apresentou um subdesenvolvimento da altura facial póstero-inferior resultando em um plano mandibular mais inclinado, e que os incisivos superiores encontravam-se acentuadamente inclinados para vestibular. 
No mesmo ano, RENFROE ${ }^{107}$ afirmou que a mandíbula encontrava-se posicionada posteriormente nos jovens com más oclusões de Classe II, $1^{\mathrm{a}}$ e $2^{\mathrm{a}}$ divisões, porém verificou que o comprimento mandibular apresentava-se similar aos dos jovens com Classe I. Em seu estudo realizados com jovens apresentando más oclusões de Classe I, e Classe $I I, 1^{\mathrm{a}}$ e $2^{\mathrm{a}}$ divisões, e comparou as alterações cefalométricas. Afirmou também que o ângulo mandibular denotava um maior aumento nos jovens com Classe I e que a maxila, avaliada pelo ponto ENA encontrava-se protruída nos casos de Classe I e de Classe II, $1^{\text {a }}$ divisão.

Ainda no mesmo ano, NELSON E HIGLEY ${ }^{96}$, compararam o comprimento do corpo mandibular em 250 jovens dos 7 aos 14 anos de idade, sendo que 153 deles apresentavam oclusão normal e má oclusão de Classe I, e 97 jovens apresentavam a má olcusão de Classe II, $1^{\mathrm{a}}$ divisão. Utilizaram medidas cefalométricas lineares para determinar o comprimento da mandíbula. Após a interpretação das mensurações cefalométricas, os resultados apontaram um menor comprimento do corpo mandibular nos casos de Classe II, $1^{\mathrm{a}}$ divisão, concordando novamente com o descrito por vários autores anteriormente $e^{44,99}$.

Perante diversos estudos sobre a má oclusão de Classe II, e no intuito de concretizar as características desta má oclusão, SALZMANN ${ }^{115}$, em 1949, relatou diversas variações desta entidade, onde observou que a maxila encontrava-se na maioria das vezes protruída, e que havia retrusão mandibular em grande parte dos casos, e ainda a combinação destes fatores.

Outra divisão estabelecida para a má oclusão de Classe II, após mais de sessenta anos da primeira ${ }^{11}$, foi a realizada por FISCHER ${ }^{50}$, em 1950, que as separou em três categorias: dentária, dentofacial e facial.

Neste mesmo ano, GILMORE ${ }^{56}$, estudando pacientes 128 adultos de ambos os gêneros, que apresentavam oclusão normal (61 pacientes) e má oclusão de Classe II, $1^{\text {a }}$ divisão (67 pacientes), concluiu que a mandíbula dos pacientes do grupo que apresentavam Classe II, $1^{\text {a }}$ divisão, mostravam-se 
significantemente menores em relação ao grupo de oclusão normal. Não observou alteração significante na posição ântero-superior da mandíbula, considerando as medidas angulares nos casos de Classe II, $1^{\text {a }}$ divisão.

Um ano após, CRAIG $^{40}$ comparou um grupo de 34 pacientes apresentando Classe I com 12 anos de idade em média, com um grupo de 33 pacientes apresentando Classe II, $1^{\text {a }}$ divisão com idade média semelhante. Utilizando um sistema gráfico de coordenadas, concluiu por meio de sobreposições, que ambos os grupos apresentaram um padrão esquelético similar, porém o grupo da Classe II, $1^{\text {a }}$ divisão apresentou um menor corpo mandibular, verificado pela distância linear Go-Gn, concordando com outros estudos realizados anteriormente $e^{44,99} 96$.

Segundo VON DER HEYDT ${ }^{130}$, a classificação convencional da Classe II, $1^{\text {a }}$ divisão de Angle $^{11}$, representa um composto que consiste de várias entidades clínicas, podendo resultar de uma retrusão do arco maxilar ou mandibular, que pode ser estrutural ou funcional.

Um ano depois, RIEDEL ${ }^{108}$ realizou uma pesquisa por meio de telerradiografias, para verificar a posição espacial da maxila e da mandíbula em relação à base do crânio nos diferentes tipos de má oclusão, e concluiu que as alterações mais significantes encontravam-se no posicionamento ânteroposterior da mandíbula, avaliado pelo ângulo SNB e na relação maxilomandibular quando verificada pelo ângulo ANB. Nos casos de Classe II, $1^{\text {a }}$ divisão, a mandíbula apresentou-se mais retruída em comparação com o grupo de oclusão normal, não verificando se esta apresentava-se subdesenvolvida ou não.

FISK et. al. ${ }^{51}$, em 1953, dando continuidade aos estudos relativos à classificação da má olcusão de Classe $\|^{11,12,44}$, identificaram que o complexo dentofacial da Classe II variava em pelo menos seis situações: maxila e dentes superiores posicionados anteriormente em relação ao crânio; dentes superiores protruídos em suas bases ósseas; mandíbula subdesenvolvida; mandíbula com 
tamanho normal, mas retruída em relação à base do crânio; dentes inferiores retruídos na base óssea ou qualquer combinação destes fatores estudados.

Os componentes dentofaciais horizontal e vertical da má oclusão de Classe II, $1^{\mathrm{a}}$ divisão foram objeto de estudo de $\mathrm{ALTEMUS}^{8}$, em 1955, onde avaliou telerradiografias de jovens do gênero feminino e conlcuiu que a maxila apresenta-se anteriormente posicionada assim como os molares superiores em relação ao grupo controle estudado, concretizando o observado em estudos anteriores $^{51,108}$.

Concordando com o estudo anteriormente realizado ${ }^{96}$, MARCONDES $^{85}$, em 1955 estudou a morfologia facial e comparou cefalometricamente um grupo de pacientes com Classe II, $1^{a}$ divisão, com um grupo controle apresentando oclusão normal. Verificou que a mandíbula no primeiro grupo apresentava-se com um menor tamanho, concordando com o proposto por vários autores anteriormente ${ }^{40,44,96,99}$, embora apresentasse uma similaridade com o grupo controle, quanto aos componentes das grandezas angulares.

Após seis décadas da primeira classificação proposta por Angle ${ }^{11}$, HENRY $^{68}$, em 1957, propôs divisões para a classificação da Classe II, $1^{\mathrm{a}}$ divisão dividindo-a em quatro tipos: protrusão maxilar alveolar, protrusão maxilar basal, deficiência do tamanho mandibular e retrusão mandibular.

Pesquisando as características faciais em telerradiografias de jovens com Classe II, $1^{\text {a }}$ divisão e com oclusão normal, KEAN ${ }^{75}$, em 1958, verificou nos casos com Classe II, que a mandíbula encontrava-se posicionada mais anteriormente em relação ao limite posterior da base craniana, porém apresentava-se com um tamanho menor do que a média, e que o trespasse horizontal acentuado resultava da posição mais para anterior dos incisivos superiores, concordando com vários outros autores ${ }^{40,44,51,96,99}$.

Na tentativa de determinar as características da Classe II, e compará-las com um grupo de oclusão normal, MARTIN ${ }^{86}$, em 1958, realizou um estudo por meio de telerradiografias de 60 jovens, sendo 20 deles com oclusão normal e 
40 com Classe II, $1^{\mathrm{a}}$ divisão. Concluiu que a mandíbula dos pacientes com Classe II apresentou-se menor e com um posicionamento mais posterior em relação aos pacientes com oclusão normal. Verificou também que a espinha nasal anterior e a borda incisal do incisivo central superior, localizavam-se projetadas para anterior nos casos de Classe II; da mesma forma, o ponto A, posicionou-se mais anteriormente nestes casos.

DE CASTRO ${ }^{42}$, em 1960, afirmou que na maioria das vezes a maxila apresenta-se bem posicionada, e a mandíbula apresenta-se retruída na má oclusão de Classe II, $1^{\mathrm{a}}$ divisão, sendo que neste caso a mandíbula necessita de um estímulo e/ou redirecionamento de seu centro de crescimento, e não há necessidade da retrusão maxilar.

Neste mesmo ano, MAJ; LUZI; LUCCHESE ${ }^{83}$, estabeleceram um trabalho com 50 jovens, com Classe II, $1^{\text {a }}$ divisão, com idades entre 8 e 15 anos, e verificaram que na maioria dos casos, ocorreu uma desarmonia entre as bases apicais, com um posicionamento anterior da maxila e posterior dos côndilos mandibulares, porém o comprimento mandibular total não apresentou grandes variações. Observaram uma inclinação acentuada para vestibular dos incisivos superiores em $78 \%$ dos casos. Concluíram portanto que a Classe II, $1^{\mathrm{a}}$ divisão, resultou de variações dentárias e esqueléticas, com tendência para a protrusão maxilar e um aumento do trespasse horizontal, devido a posição dos dentes anteriores, contradizendo o exposto por DE CASTRO ${ }^{42}$, no ano anterior.

Dois anos depois, contrariando os resultados de MAJ; LUZI; LUCCHESE $^{83}$, e concordando com DE CASTRO ${ }^{42}$, KING ${ }^{76}$ comparou amostras de Classe I e Classe II, de adultos de ambos os gêneros, e evidenciou que no grupo de Classe II, $1^{\mathrm{a}}$ divisão, a mandíbula apresentou-se retruída em relação à base do crânio, e os incisivos superiores mostraram-se inclinados para vestibular. Não encontrou diferença significante entre os grupos com relação à posição da maxila. 
SASSOUNI ${ }^{119}$, em 1970, afirmou haver pelo menos 64 situações diferentes nas más oclusões de Classe II, com mordida profunda, e outras 64 para as más oclusões de Classe II com mordida aberta.

Novamente, em 1971, outro autor, ROTHSTEIN ${ }^{112}$, analisou e comparou as características morfológicas e o crescimento facial de jovens com oclusão normal e com má olcusão de Classe II, $1^{\text {a }}$ divisão. Utilizou uma amostra de 273 jovens portadores de oclusão normal e 335 com Classe II, $1^{\text {a }}$ divisão. Por meio de seus estudos concluiu que os jovens que apresentavam a má oclusão de Classe II, $1^{\text {a }}$ divisão apresentaram a maxila maior do que o normal, o plano palatino inclinado no sentido anti-horário e a mandíbula bem posicionada, com tamanho e formas normais.

Outro trabalho que estudou as características mandibulares quanto à posição e dimensões na Classe I e Classe II, $1^{\text {a }}$ divisão foi o de VIGORITO ${ }^{129}$, em 1973, onde constatou que a mandíbula apresentou uma posição mais retruída à base do crânio, nos casos de Classe II, $1^{\text {a }}$ divisão. Observou também que a borda inferior do corpo mandibular mostrou tendência para exibir inclinação nos casos de Classe II e que nestes casos, o comprimento mandibular apresentou-se menor.

Após vários outros autores ${ }^{11,12,51,86}$, SERVOSS $^{122}$, em 1975, acrescentou quatro termos à classificação de Angle, proposta inicialmente, onde os termos prognatismo ou retrognatismo referem-se ao posicionamento anterior ou posterior, respectivamente, das bases ósseas em relação ao esqueleto craniofacial. Os termos protrusão e retrusão descrevem o posicionamento anterior e posterior dos dentes em relação às bases ósseas. Concluiu que a Classe II, $1^{\text {a }}$ divisão pode resultar de uma protrusão dos dentes superiores, um prognatismo maxilar, uma retrusão do arco dentário inferior, um retrognatismo mandibular ou mais freqüentemente, de uma combinação destes fatores.

Neste mesmo ano, e dando continuidade aos trabalhos relativos às características da má oclusão de Classe II, $1^{\mathrm{a}}$ divisão, PFEIFFER; GROBÉTY ${ }^{100}$, afirmaram que a má oclusão de Classe II provém da 
combinação de alterações dentoesqueléticas, e que na maioria dos casos a maxila apresenta-se bem posicionada e os incisivos superiores protruídos. A retrusão da mandíbula foi comumente observada com os incisivos inferiores bem posicionados.

Mais uma vez foram propostas várias outras novas classificações para a má oclusão de Classe II, na década de $80^{94,133}$.

De acordo com as possibilidades etiológicas, WOODSIDE ${ }^{133}$ em 1980, descreveu sete tipos de Classe II dentoalveolares, esqueléticas e musculares, e dividiu em 7 subtipos: 1) face harmoniosa com Classe II dentoesquelética; 2) protrusão do complexo nasofaríngeo e mandíbula bem posicionada; 3) complexo nasofaríngeo normal e mandíbula retruída; 4) complexo nasofaríngeo normal, mandíbula muito retruída e perfil facial bastante convexo; 5) complexo nasofaríngeo e maxila protruídos com mandíbula retruída; 6) relação maxilomandibular adequada com obstrução nasal ocasionando retrusão da mandíbula quando em repouso e 7) variação do subtipo 1, com espaço funcional livre muito aumentado.

Também no ano de 1980, MOYERS et. al. ${ }^{94}$, definiram vários outros tipos de Classe II com características verticais e horizontais bem definidas, por meio de uma combinação de programas computadorizados. Determinaram seis tipos horizontais: uma "Pseudo-Classe II" ou Classe II dentária; quatro síndromes de Classe II esqueléticas graves; e um caso moderado de Classe II esquelética, com uma variedade de sintomas. Encontraram também cinco tipos verticais, onde o primeiro apresentava o plano mandibular acentuadamente inclinado para baixo; no segundo, os planos mandibular, oclusal e palatino encontravam-se quase paralelos entre si; o terceiro mostrava o plano palatino inclinado para cima; o quarto, os planos mandibular, oclusal e palatino apresentavam-se acentuadamente inclinados para baixo; e o quinto, os planos mandibular e oclusal denotavam normalidade, e o plano palatino encontrava-se inclinado para baixo. Por meio da marcante relação entre os dois padrões, vertical e horizontal, identificaram quinze subtipos com características bem definidas. Ressaltaram que pacientes que apresentam um mesmo tipo de 
Classe II, com aparência e padrão de crescimento semelhantes, necessitavam de tratamentos similares e provavelmente responderiam da mesma maneira.

MCNAMARA JÚNIOR ${ }^{90}$, em 1981, concluiu que a Classe II não é uma entidade clínica simples, podendo resultar de inúmeras combinações de componentes dentários e esqueléticos. Para obter um correto planejamento para a correção da Classe II torna-se necessário identificar a morfologia desta má oclusão. Com a finalidade de verificar a natureza e a freqüência com que ocorrem as principais características envolvidas na má oclusão de Classe II, investigou cefalometricamente uma amostra de 277 jovens, sendo 153 do gênero masculino e 124 do feminino, com idade média de 9 anos, incluindo tanto a Classe II, $1^{\underline{a}}$ divisão como a Classe II, $2^{\underline{a}}$ divisão. Com este estudo observou que esta má oclusão não é uma entidade clínica única, podendo resultar de inúmeras combinações de componentes dentários e esqueléticos. 0 autor verificou que, em média, a maxila apresentou-se bem posicionada, ou até mesmo retruída enquanto que a retrusão mandibular foi a característica mais evidenciada na amostra de Classe II. Além disso, os pacientes apresentaram uma marcante variação no desenvolvimento vertical e pelo menos na metade da amostra observou um excessivo desenvolvimento vertical. A avaliação dentária revelou que os incisivos superiores apresentavam-se inclinados para vestibular e os inferiores bem posicionados, na maioria dos casos.

No ano seguinte, BASS $^{17}$, em 1982, destacou a grande influência da musculatura bucofacial no desenvolvimento da face e no posicionamento dentário, possibilitando inclusive alterações no crescimento das estruturas faciais. Avaliando os componentes dentoesqueléticos da má oclusão de Classe II, $1^{\text {a }}$ divisão, o autor observou uma protrusão da maxila e retrusão mandibular ou ainda, em alguns casos, a maxila apresentava-se retruída e a mandíbula acentuadamente retruída.

Correlacionando a altura da base do crânio e a dimensão craniofacial na má oclusão de Classe II, 1aㅡ divisão, ANDERSON; POPOVICH ${ }^{9}$, em 1983 avaliaram jovens com idades entre 8 e 16 anos. Observaram que nesta má oclusão o ângulo da base do crânio e a altura da base craniana superior 
encontram-se aumentados enquanto que a altura da base craniana inferior apresenta-se diminuída. A maxila localiza-se suavemente e a mandíbula acentuadamente para posterior.

Avaliando cefalometricamente as estruturas dentoesqueléticas de 50 pacientes de ambos os gêneros, com Classe II, 1a divisão, VALE ${ }^{128}$, em 1985 , concluiu que: a posição da maxila apresentou-se variável, com uma suave tendência para a protrusão; os incisivos superiores demonstraram uma tendência excessiva para a protrusão; a análise da posição mandibular, utilizando três grandezas cefalométricas, não permitiu uma conclusão definitiva, quando comparados entre si. Entretanto, afirmou que, uma grande porcentagem dos casos apresentou uma posição mandibular variando do normal para o retrognatismo; os incisivos inferiores apresentaram uma posição mais retrusiva; não foi observado dimorfismo genérico, e ocorreu uma acentuada predisposição para o desenvolvimento vertical excessivo do complexo craniofacial com conseqüente aumento da altura anterior da face.

Mais uma vez as alterações dentofaciais em jovens com más oclusões de Classe II, $1^{\text {a }}$ divisão não tratados, foram alvo de estudo, e desta vez pesquisadas por CARTER ${ }^{36}$, em 1987. O autor avaliou estudos cefalométricos que compararam os valores médios para indivíduos com má oclusão de Classe II, $1^{\underline{a}}$ divisão com padrões cefalométricos normais. Concluiu que, nos jovens com Classe II, a maxila apresenta-se bem posicionada em relação à base do crânio e a mandíbula moderadamente retruída e os incisivos superiores mostraram-se protruídos quando comparados com amostras controle. O autor ressaltou ainda que o aumento médio nas dimensões lineares foi quase três vezes maior nos jovens do gênero masculino comparado ao feminino. Não obstante se verificou uma considerável variação individual, houve uma maior tendência de redução do trepasse horizontal nos jovens do gênero masculino, porém, não observado no gênero feminino.

Objetivando estudar o comportamento da mandíbula na má oclusão de Classe II, 1ํa divisão, BUSCHANG et al. ${ }^{34}$, em 1988, compararam o crescimento da mandíbula em 42 jovens do gênero feminino e 71 do masculino, dos 6 aos 
15 anos de idade, com Classe II, 1a divisão, não tratados, com um grupo de jovens possuindo oclusão normal. Os resultados demonstraram um menor crescimento da mandíbula nos pacientes com Classe II, como já apresentado por outros autores ${ }^{75,85,96}$. O ângulo SN.Gn, nestes jovens apresentou um maior aumento comparando-se com o grupo de oclusão normal, onde a mandíbula exibiu uma rotação no sentido anti-horário.

Ainda com relação ao tamanho diminuído da mandíbula na má olcusão de Classe II, $1^{\text {a }}$ divisão, PROFFIT ${ }^{106}$, em 1993, afirmou que os principais componentes desta má oclusão são definidos pela deficiência do crescimento mandibular, por um crescimento maxilar excessivo ou ainda por uma combinação dos fatores supracitados.

Novamente os estudos da má olcusão de Classe II, $1^{\mathrm{a}}$ divisão restringiram-se à mandíbula no estudo de SARHAN; HASHIM ${ }^{118}$, em 1994, onde verificaram nos jovens com mandíbula retruída, uma retrusão maxilar com o ângulo SNA mostrando-se diminuído, os ângulos dos planos mandibular, palatino e oclusal normalmente apresentaram-se aumentados bem como a altura facial total, e os incisivos inferiores denotaram uma inclinação correta. Por outro lado, nos jovens com mandíbulas de tamanho normal, evidenciou-se uma protrusão maxilar com o ângulo SNA aumentado, os ângulos dos planos mandibular, palatino e oclusal mostraram-se diminuídos e os incisivos inferiores inclinados para vestibular.

No mesmo ano, KARLSEN ${ }^{74}$ avaliou a morfologia craniofacial na má oclusão de Classe II, $1^{\underline{a}}$ divisão em dois grupos compostos por 24 jovens com mordida aberta e 22 com mordida profunda. Um outro grupo com 25 jovens apresentando oclusão "normal" foi analisado como grupo controle. Os resultados mostraram que os jovens com má oclusão de Classe II apresentavam um comprimento mandibular diminuído, como já demonstrado anteriormente ${ }^{34,75,85,96}$, e um retrognatismo caracterizando a principal causa da relação de distoclusão. A altura facial ântero-inferior apresentou-se maior nos jovens com mordida aberta, bem como o ângulo do plano mandibular em comparação ao grupo controle. Nos jovens com mordida profunda a altura 
facial ântero-inferior mostrou-se diminuída em comparação com o grupo controle.

Um trabalho voltado mais para os valores esqueléticos relacionados à má oclusão de Classe II, $1^{\mathrm{a}}$ divisão foi o de ROSENBLUM ${ }^{111}$, em 1995, sendo que para o estudo o autor utilizou telerradiografias de 103 jovens com má oclusão de Classe II e analisou 4 medidas cefalométricas para avaliação da maxila e outras 4 para a mandíbula. Os resultados demonstraram uma ampla variedade de protrusão maxilar e retrusão mandibular. De acordo com o ângulo facial de Downs notou que $27 \%$ da amostra apresentou retrusão mandibular, enquanto que o ângulo NA.FH (linha NA com o plano horizontal de Frankfort) demonstrou uma protrusão maxilar em 56,3\% dos jovens analisados. Assim, concluiu que o padrão predominante destes jovens foi o de protrusão maxilar com uma mandíbula normal.

Com o objetivo de comparar as características morfológicas entre a Classe I, II e III de Angle ${ }^{11}$, DIBBETS ${ }^{43}$ em 1996, avaliou 170 jovens antes de receberem tratamento ortodôntico. Verificou que algumas diferenças entre a Classe I, II e III concentram-se nas dimensões da face média e base do crânio. O ângulo da base do crânio é mais fechado e as porções anterior (S-N) e posterior (S-Ba) são mais curtas na má oclusão de Classe II. O tamanho mandibular não apresentou diferença entre as más oclusões. O autor salientou que a base do crânio propicia condições para o desenvolvimento maxilar, e que a face média é a principal responsável pelas características da Classe II.

Com o intuito de comparar longitudinalmente as alterações dentofaciais em jovens com Classe II, $1^{\underline{a}}$ divisão e jovens com oclusão normal, BISHARA et al. $^{26}$, em 1997, utilizaram dois grupos que foram estudados durante a fase de dentadura decídua à dentadura permanente. O primeiro grupo constituiu-se de 30 jovens, com Classe II, 1ํa divisão, sendo 15 do gênero masculino e 15 do feminino. O grupo 2 (grupo controle) apresentava 35 jovens, com oclusões normais, sendo 20 do gênero masculino e 15 do gênero feminino. Para avaliação e comparação dos resultados, foram tomadas telerradiografias em norma lateral em três estágios diferentes, destacando-se: um primeiro estágio, 
dentadura decídua completa (5,5,anos); um segundo estágio, quando da total irrupção dos molares permanentes (8 anos); e por fim um terceiro estágio, dentadura permanente completa (12 anos) com exceção dos $3^{\text {os }}$ molares. Após a obtenção das grandezas cefalométricas e da análise estatística, concluíram, por meio da comparação transversal das amostras, que as diferenças no comprimento e na posição da mandíbula entre os jovens com Classe II e jovens com oclusão normal, foram significantes somente no primeiro estágio, porém não significantes no terceiro estágio. O comprimento mandibular, investigado pela grandeza linear Ar-Pog, encontrava-se diminuído no grupo com Classe II, em ambos os gêneros, quando da comparação com o grupo controle no primeiro estágio. Isto indica que o crescimento mandibular nos jovens com Classe II, $1^{\underline{a}}$ divisão, pode ocorrer num período mais tardio de desenvolvimento (segundo ou terceiro estágios), alcançando o desenvolvimento normal da mandíbula em jovens com oclusão normal. Observaram, pela comparação longitudinal dos grupos, que o padrão de crescimento esquelético-facial praticamente não sofre alteração, com exceção da protrusão do lábio superior. A comparação da magnitude de crescimento, apontada por diferenças significantes nas grandezas cefalométricas, indicou grandes alterações na convexidade esquelética e facial dos jovens com Classe II, $1^{\underline{a}}$ divisão, acompanhadas por uma tendência à retrusão mandibular. O crescimento da base do crânio ocorreu similarmente em ambos os grupos, porém nos jovens com Classe II, o ângulo de convexidade esquelética diminuiu com o crescimento, enquanto que o ângulo de convexidade facial aumentou.

No mesmo ano e seguindo os mesmos parâmetros para a realização da pesquisa anterior, BACCETTI et al. $^{14}$ utilizaram dois grupos que foram avaliados longitudinalmente (2 anos e 6 meses) desde a fase de dentadura decídua à dentadura mista. Os grupos constituíam-se de 25 jovens com má oclusão de Classe II e 22 jovens com oclusão "normal". Os autores observaram que a relação de Classe II apresentada inicialmente, se manteve ou se tornou ainda pior durante o período avaliado. O padrão esquelético da Classe II caracterizou-se por uma retrusão mandibular significante, por uma deficiência no comprimento efetivo da mandíbula e uma rotação deste osso no sentido horário. Por outro lado, a maxila apresentou um crescimento para anterior 
significante. Concluíram que os sinais clínicos da má oclusão de Classe II são evidentes na dentadura decídua e persistem na dentadura mista.

Mais uma vez levando em consideração principalmente o estabelecimento do protocolo de tratamento para jovens com má olcusão de Classe II, URSI; MCNAMARA JUNIOR ${ }^{127}$, em 1997, realizaram um estudo com um grupo de 29 jovens com Classe II e outro grupo de 30 jovens apresentando oclusão normal. Comparando os grupos, verificaram uma semelhança no posicionamento da maxila e uma retrusão mandibular no grupo com Classe II. Quanto aos dentes, os incisivos e molares superiores apresentaram-se mais extruídos e os incisivos inferiores mais protruídos e extruídos nos jovens com Classe II.

As principais características da má oclusão de Classe II, 1a divisão foram estudadas novamente no ano de 1997, por NGAN; BYCZEK; SCHEICK ${ }^{97}$, sendo que avaliaram longitudinalmente as alterações esqueléticas desta má oclusão comparando-a com jovens apresentando Classe I. A amostra constituiu-se de 40 jovens do gênero feminino entre as idades de 7 e 14 anos, dividida em 2 grupos de 20 jovens cada, sendo um composto por jovens com Classe I e outro por indivíduos com Classe II, 1a divisão. Os resultados demonstraram que não houve diferença significante entre os dois grupos na dimensão da base do crânio. A maxila apresentou-se bem posicionada em relação à base do crânio (SNA) nos jovens com Classe II. Entretanto, verificouse uma retrusão mandibular, (SNB) e um comprimento mandibular (Ar-Gn) e do corpo mandibular (Go-Gn) diminuídos quando da comparação entre os grupos. $\mathrm{O}$ ângulo do plano mandibular e o eixo " $\mathrm{Y}$ " de crescimento encontraram-se aumentados na Classe II, contribuindo para uma retroposição da mandíbula. A relação maxilomandibular (ANB) mostrou-se significantemente maior na amostra de Classe II aos 7 anos e se manteve aumentada até a puberdade. Concluindo, os autores sugeriram que o padrão esquelético da Classe II se estabelece precocemente e se mantém até a puberdade, se não submetida à intervenção ortodôntica. 
Um estudo sobre as características dentoesqueléticas da má oclusão de Classe II, $1^{\text {a }}$ divisão em jovens não tratados ortodonticamente foi conduzido por HENRIQUES et. al. ${ }^{66}$ em 1998. O trabalho constituiu-se de uma amostra de 25 jovens com idade inicial de 9 anos e 4 meses que foram acompanhados longitudinalmente por 3 anos e 4 meses. Os resultados demonstraram que em $75 \%$ dos casos a mandíbula apresentou-se retruída, enquanto a maxila variou entre retruída, bem posicionada e protruída. O padrão de crescimento denotou variabilidade, com distribuição uniforme de indivíduos com predominância de crescimento vertical, horizontal e equilibrado. A altura facial ântero-inferior aumentou em decorrência do crescimento facial. A relação maxilomandibular não mostrou melhora significante, mantendo a discrepância esquelética da má oclusão de Classe II, $1^{a}$ divisão. Em relação ao componente dentário, verificaram que os molares e incisivos superiores acompanharam o crescimento maxilar, apresentando mesialização e extrusão; enquanto os inferiores também extruíram, porém com a mesialização apenas dos molares e retrusão dos incisivos agravando o trepasse horizontal.

Mais um trabalho com o intuito de estudar cefalometricamente as características da Classe II, $1^{\mathrm{a}}$ divisão, MAIA et al. ${ }^{82}$, em 1998 , utilizaram uma amostra de 100 jovens (50 do gênero masculino e 50 do feminino) com idades variando de 6 anos e 11 meses a 14 anos e 3 meses. A avaliação dos resultados obtidos permitiu o estabelecimento das seguintes conclusões: (1) predomínio de um vetor de crescimento vertical; (2) dominância do perfil facial convexo, com a maxila normal ou protruída e a mandíbula com definida tendência retrusiva; (3) os incisivos superiores e inferiores apresentaram-se inclinados para vestibular e protruídos, enquanto que o trepasse horizontal encontrava-se aumentado e o vertical, normal.

No mesmo ano, BISHARA ${ }^{25}$ avaliou as alterações mandibulares em jovens com Classe II, 1a divisão não tratados, considerando estas alterações nos sentidos longitudinal e transversal. Utilizou a mesma amostra e metodologia do seu trabalho publicado em 1997. Após análise dos resultados, concluiu que as diferenças no comprimento e na posição da mandíbula entre os jovens com Classe II e jovens com oclusão normal, foram mais significantes 
na dentadura decídua. A comparação da magnitude de crescimento, apontada por diferenças significantes nas grandezas cefalométricas, indicou grandes alterações na convexidade esquelética e facial dos jovens com Classe II, 1a divisão, acompanhadas por uma tendência a maior retrusão mandibular.

Um artigo que possui muita importância no âmbito do tratamento da Classe II, principalmente precocemente, não especificamente tratando somente deste tipo de má olcusão, mas dando um enfoque especial à ela, é o trabalho de ALMEIDA et. al. ${ }^{6}$, realizado em 1999, especificando inclusive as caracterísitcas, o desenvolvimento e o tratamento desta má olcusão.

No ano de 2000, ROTHSTEIN; YOON-TARLIE ${ }^{113}$, realizaram um estudo onde as características dentofaciais e craniofaciais da má oclusão de Classe II, 1ํ divisão foram enfocadas. Avaliaram 613 telerradiografias em norma lateral, sendo 278 de jovens com oclusão normal e 335 de jovens com má oclusão de Classe II, não tratados. Os resultados demonstraram que a mandíbula apresentou o mesmo tamanho, forma e posicionamento entre os grupos, enquanto que a maxila apresentou-se mais protruída no grupo com Classe II, assim como os incisivos e o molares superiores que se encontraram posicionados mais mesialmente em relação ao grupo controle.

Outro estudo muito relevante, e que comparou as dimensões maxilomandibulares entre jovens com má oclusão de Classe II, 1a divisão, não tratados e jovens com oclusão normal, foi o de GURGEL; ALMEIDA; PINZAN ${ }^{57}$, em 2000, por meio de um estudo cefalométrico. Os autores verificaram que em relação ao ponto $A$, não houve diferença significante entre os grupos, indicando que a protrusão maxilar, muitas vezes associada a má oclusão de Classe II, $1^{\underline{a}}$ divisão não se manifestou neste estudo. Não obstante, os valores das medidas horizontais da mandíbula mostraram uma significante diferença e por outro lado, os valores verticais não apresentaram valores equiparáveis entre os grupos. Assim, os autores concluíram que a diferença mais evidente restringiuse as dimensões ântero-posteriores da mandíbula, enquanto que a maxila equiparou-se nos sentidos horizontal e vertical. Entretanto, o posicionamento 
da maxila apresentou uma variabilidade sendo possível encontrá-la protruída ou retruída em diferentes casos.

No ano seguinte, destacando a importância da análise facial como exame auxiliar no diagnóstico e planejamento ortodôntico, BRANDÃO; DOMINGUEZ-RODRÍGUEZ; CAPELOZZA FILHO ${ }^{29}$ avaliaram as características da má oclusão de Classe II, 1a divisão, observadas nas telerradiografias e compararam-as com as características morfológicas da face, verificadas na análise facial subjetiva. A amostra constou de 30 jovens, de ambos os gêneros, com idades entre 12 e 16 anos. A análise cefalométrica mostrou perfil ósseo convexo, maxila bem posicionada e mandíbula retruída em relação à base do crânio, incisivos superiores e inferiores protruídos nas bases ósseas, trespasse horizontal acentuado e vertical moderado. O exame facial subjetivo mostrou um envolvimento da maxila em 3 casos (10\%); da mandíbula em 13 casos (43,3\%); associação da maxila e mandíbula em 43,3\% (13 casos) e maxila e mandíbula consideradas bem posicionadas em apenas 1 caso (3,3\%). Assim, concluíram que a avaliação subjetiva apresentou uma razoável coerência comparada aos valores obtidos na análise cefalométrica.

As alterações dentoalveolares relacionadas ao crescimento mandibular em jovens com má oclusão de Classe II foram avaliadas novamente em 2001 por YOU et al. ${ }^{135}$. A amostra constou de 40 jovens com Classe II não tratados que foram comparados a uma amostra de oclusão normal de Bolton. Os autores não observaram diferenças estatísticas no crescimento mandibular entre as duas amostras. No grupo com má oclusão de Classe II o complexo dentoalveolar posicionou-se para anterior em relação à maxila (ponto A) e para posterior em relação à mandíbula (ponto $P$ ). Os resultados indicaram que o crescimento para anterior da mandíbula e conseqüentemente o posicionamento dos dentes inferiores no mesmo sentido contribuem para a correção da Classe II. Os autores afirmaram que a base biológica fundamental para o tratamento desta má oclusão consiste numa terapia que desoclui os dentes, por meio de levantamento do plano oclusal e desta forma, libera o crescimento da mandíbula. 
Um ano após, KLOCKE; NANDA; KAHL-NIEKE ${ }^{78}$ estudaram longitudinalmente as características esqueléticas da má oclusão de Classe II. A amostra constou de 23 jovens com Classe II que foram observados dos 5 aos 12 anos de idade e divididos em dois grupos de acordo com o comportamento do ângulo ANB. Um grupo de 13 jovens que apresentou uma diminuição do ângulo ANB (pelo menos 1,5 grau) durante o período de avaliação foi denominado como grupo de crescimento favorável. No outro grupo, denominado de crescimento desfavorável, os 10 jovens apresentaram um aumento dos ângulos ANB, SN.PP, do ângulo goníaco e da distância N-Me e uma diminuição da proporção das alturas faciais posterior e anterior. Os autores afirmaram que a melhora no relacionamento maxilomandibular no grupo de crescimento favorável ocorreu devido ao posicionamento da mandíbula. No outro grupo, a rotação posterior (aumento da altura facial posterior) parece ocorrer devido a um mecanismo de compensação adaptativo pelo subdesenvolvimento da mandíbula.

Mais atualmente (2003), ALARASHI et. al. ${ }^{1}$, objetivaram avaliar as características dentoesqueléticas da Classe II no sentido transversal. Para o estudo utilizaram radiografias póstero-anterior de 49 jovens com Classe II não tratados que foram comparadas com 50 jovens com Classe I também não tratados ortodonticamente. Os resultados demonstraram uma atresia da maxila, tanto esquelética como dentoalveolar, e um estreitamento da base do nariz no grupo com Classe II. Os autores asseguraram que a constrição maxilar associou-se com um aumento vertical da maxila.

Também em 2003, e considerando uma amostra brasileira apresentando a má oclusão de Classe II, BERTOZ et al. ${ }^{23}$ determinaram alguns parâmetros cefalométricos para este grupo, no intuito de contribuir para o diagnóstico ortopédico-ortodôntico. Utilizaram para o estudo 55 telerradiografias de 31 jovens do gênero feminino e 24 do masculino com idade média variando entre 6 e 11 anos. Os resultados revelaram que em mais da metade da amostra a maxila encontrou-se bem posicionada ou ainda retruída e a mandíbula apresentou retrusão em relação à base do crânio. Com relação ao padrão de crescimento verificou-se que $60 \%$ a $70 \%$ apresentou crescimento vertical. Os 
incisivos superiores encontraram-se inclinados para vestibular excessivamente e protruídos e os inferiores, em cerca de 50\% da amostra estavam vestibularizados sendo que a outra metade apresentava-se bem posicionados e protruídos. Os autores afirmaram que no tratamento da Classe II deve-se considerar as características pertinentes a cada paciente.

Neste mesmo ano (2003), mais um estudo desenvolvido por SANTOS ${ }^{116}$ contribuiu para a caracterização cefalométrica da má oclusão de Classe II, $1^{\underline{a}}$ divisão esquelética. A amostra desta pesquisa consistiu de 55 jovens brasileiros, leucodermas, de ambos os gêneros, com idade média de 13 anos e 6 meses. Os resultados mostraram a maxila bem posicionada e a mandíbula retruída em relação à base do crânio. Em relação à proporcionalidade das bases apicais evidenciou-se a mandíbula com dimensão pequena e a maxila normal. O padrão facial demonstrou um comportamento de crescimento vertical. Os incisivos superiores e inferiores apresentaram-se inclinados para vestibular.

\subsubsection{CONCLUSÃO DOS ARTIGOS RELACIONADOS ÀS CARACTERÍSTICAS DA MÁ OCLUSÃO DE CLASSE II, 1ª DIVISÃO:}

Analisando e relacionando os trabalhos relativos à Classe II $1^{\text {a }}$ divisão, constatou-se o grande número de variáveis envolvidas neste tipo de má oclusão. Sabe-se que a má oclusão de Classe II apresenta uma discrepância maxilomandibular, um mau relacionamento dos arcos dentários superior e inferior, ou uma combinação destes fatores, possuindo um envolvimento das bases ósseas no sentido sagital, vertical e transversal. Pode-se constatar que esta má oclusão pode estar relacionada à presença isolada ou à combinação do prognatismo maxilar, do retrognatismo mandibular, com retrusão dos dentes inferiores e protrusão dos superiores, sendo o retrognatismo mandibular considerado como um dos maiores responsáveis por esta má oclusão, quando avaliamos as alterações sagitais da Classe II. Uma combinação destes fatores com um excesso vertical da maxila ou uma deficiência transversal desta base óssea, pode também existir, denotando a presença de alterações nos três planos: horizontal, vertical e transversal. A maioria das pesquisas ressalta a 
grande variação existente de apresentações dentárias e esqueléticas deste tipo de má oclusão, mas há uma maior tendência ao retrognatismo mandibular. Sem dúvida é de total importância o conhecimento amplo com relação o crescimento craniofacial e a morfologia desta má oclusão, para que possamos diagnosticar e aplicar o tratamento com um melhor prognóstico possível.

\subsection{TRATAMENTO DA MÁ OCLUSÃO DE CLASSE II, $1^{\text {a }}$ DIVISÃO COM O USO DO APARELHO EXTRABUCAL CONJUGADO (SPLINT MAXILAR)}

$\mathrm{Na}$ literatura pertinente observamos que há um grande número de trabalhos publicados relacionados à tração extrabucal, mas principalmente à tração cervical e occipital, sendo que diretamente relacionados ao aparelho extrabucal conjugado (Splint maxilar) são poucos estes trabalhos. Os artigos que tratam do aparelho extrabucal conjugado serão expostos e comentados neste tópico.

O pioneiro em utilizar um aparelho extrabucal inserido em tubos soldados a grampos de aparelhos removíveis foi McCALIN ${ }^{89}$, em 1953. E em 1961, PLINT ${ }^{102}$ verificou que ocorriam distorções dos grampos destes aparelhos em função da força excessiva, e propôs a bandagem dos molares onde o arco facial seria inserido e o aparelho removível apresentaria grampos em forma de " $\mathrm{C}$ " nos molares, abraçando a banda por cima, evitando assim tais problemas.

Outro aparelho onde os tubos eram incorporados no acrílico do aparelho removível na distal dos incisivos centrais superiores e com levantamento de mordida foi desenvolvido em 1965, por COUSINS; CLARK ${ }^{39}$. 
Alguns anos mais tarde, THUROW ${ }^{124}$, especificamente em 1975, relatou que possuía uma preocupação com os efeitos secundários indesejáveis e a sobrecarga que os molares sofriam em virtude das forças extrabucais intensas, e identificou alguns desses problemas:

1) O componente vertical das forças produzem inclinações colaterais vestibulolinguais dos dentes de ancoragem;

2) O nível de aplicação da força é limitada pela tolerância e a resposta dos tecidos de suporte destes dentes;

3) A movimentação dos molares é a alteração dentária predominante.

Com base nestas limitações constatadas, THUROW ${ }^{124}$ desenvolveu um aparelho destinado à correção das más oclusões de Classe II, $1^{\text {a }}$ divisão, com o diagnóstico estabelecido na protrusão maxilar ou dentoalveolar. O aparelho consistia de uma placa de acrílico que recobria o palato, as superfícies oclusais dos dentes posteriores, estendendo-se até 2/3 das superfícies vestibulares desses dentes e as superfícies palatinas, incisais e vestibulares dos incisivos superiores. O braço interno do arco extrabucal era incorporado no acrílico e percorria as superfícies oclusais dos dentes posteriores. Observando os efeitos de seu novo aparelho, verificou que a desoclusão promovida pelo recobrimento oclusal, facilitou tanto a movimentação dentária, como a correção de deslocamentos funcionais da mandíbula porque eliminou as interferências existentes. Esse recobrimento possibilitou ainda uma distribuição uniforme da força por todo o arco dentário, promovendo um controle vertical eficiente. Como resultado, obteve uma distalização dos dentes posteriores, um controle de inclinação dos dentes anteriores conforme são deslocados para lingual e, a inclinação distal dos caninos. Evidenciou também uma restrição do deslocamento ântero-inferior do complexo maxilar, com conseqüente restrição da rotação mandibular no sentido horário, que advém do crescimento vertical desproporcional da maxila.

Dois anos após, JOFFE; JACOBSON ${ }^{72}$ (1979), desenvolveram um aparelho similar ao de THUROW ${ }^{124}$, com o propósito de realizar pequenos ajustes na inclinação dos incisivos superiores, que freqüentemente 
apresentam-se vestibularizados nas más oclusões de Classe II, $1^{\text {a }}$ divisão. Os autores incorporaram um arco vestibular à placa de acrílico e verificaram como efeito do aparelho uma retração em massa do arco dentário superior com algum grau de restrição de crescimento maxilar, além de constatarem também uma melhora no trespasse horizontal e da relação molar.

BASS $^{17}$ em 1982, realizou as suas modificações com base no Splint que havia sido proposto anteriormente ${ }^{124}$, e desenvolveu um outro tipo de "splint"maxilar, que consistia em uma placa de acrílico cobrindo o palato e preso aos dentes posteriores por meio de grampos. Lateralmente à área dos primeiro molares foram posicionados tubos que permitiram a colocação do arco extrabucal. Um parafuso expansor para ajustes laterais foi acrescentado ao acrílico. A tração foi direcionada para o centro de resistência maxilar e, como os dentes transmitem a força extrabucal para os ossos e desses para as suturas que os articulam ao esqueleto facial, argumentou que foi a compressão dessas suturas que levou à restrição do crescimento nesse nível, inibindo o deslocamento para frente da maxila. Enquanto o crescimento maxilar é inibido, uma redução da discrepância da base dentária deve ocorrer. As forças agindo em uma direção vertical para cima na dentadura superior, pela ação de cobertura dos dentes posteriores tenderam a retardar a erupção destes e esse efeito é vantajoso na correção da relação molar de Classe II, uma vez que os molares inferiores estão livres para irromper para frente e para cima. Essa correção posteriormente foi auxiliada por uma conseqüente redução na tendência da mandíbula de rotacionar no sentido horário durante o tratamento, um efeito adverso freqüentemente visto com a terapia extrabucal convencional. O movimento distal em massa de todo o arco dentário superior constituiu em outro efeito benéfico observado. Os resultados cefalométricos mostraram a manutenção do valor do ângulo SNA e o aumento do SNB, conseqüentemente gerando uma redução do ângulo ANB de $2,5^{\circ}$ em média, diminuindo portanto a discrepância existente entre as bases ósseas.

Um ano após (1983), FERGUSON ${ }^{48}$ interessado em associar a força extrabucal ao aparelho removível, propôs a inserção do arco extrabucal na 
altura dos molares, soldando um tubo em um fio de 0,9mm sobre os grampos de Adams. Afirmou que desta forma não há perigo de distorção dos grampos, além da vantagem de não ser necessário bandar os molares e da praticidade do arco facial poder ser retirado, mantendo-se o aparelho removível na boca.

Após tantas modificações propostas ao aparelho extrabucal "Splint" maxilar, CALDWELL; HYMAS; TIMM ${ }^{35}$, em 1984, com o objetivo de avaliar cefalometricamente as alterações promovidas pelo "splint" maxilar, realizaram uma pesquisa, sendo que a amostra constou de dois grupos com Classe II, sendo um grupo de 47 jovens tratados com o aparelho extrabucal associado ao removível e outro grupo de 52 jovens com a mesma má oclusão que não receberam tratamento ortodôntico, e portanto serviram como grupo controle. Os resultados mostraram uma restrição do crescimento maxilar para frente e para baixo, com diminuição do ângulo SNA e uma melhora significativa na relação maxilomandibular. Não houve alterações significantes no padrão de crescimento, porém observou-se um aumento da altura facial ântero-inferior. Com relação às alterações dentárias, constataram uma redução do trespasse vertical e horizontal, lingualização dos incisivos superiores e distalização dos molares superiores, enquanto os inferiores verticalizaram, mesializaram e extruíram.

Outro estudo também preocupado em avaliar os efeitos do "splint" maxilar foi o realizado por FOTIS et. al. ${ }^{53}$ em 1989. O aparelho utilizado diferia do "splint" original pois os tubos para o arco extrabucal eram inseridos diretamente no acrílico, na região dos molares. Verificaram que, em todos os casos, houve uma redução no trespasse horizontal. O crescimento da maxila apresentou uma restrição no sentido sagital (SNA) e vertical e a mandíbula protruiu (SNB). Os incisivos superiores e inferiores inclinaram para lingual, os molares superiores distalizaram e os inferiores extruíram e mesializaram.

Um ano depois (1990), SEÇKIN; SURUCU ${ }^{121}$ estudaram os efeitos produzidos por um "splint" maxilar semelhante ao de THUROW ${ }^{124}$ porém com o acrílico recobrindo apenas as superfícies oclusais, vestibulares e linguais, 
deixando a mucosa palatina livre. O estudo constitui-se de 15 pacientes com má oclusão de Classe II, 1므 divisão com protrusão maxilar. Os resultados mostraram uma restrição do crescimento maxilar com diminuição do ângulo SNA e mínima alteração no posicionamento da mandíbula. No sentido vertical observou-se um suave aumento dos ângulos SN.PP, SN.GoGn e FMA. Os incisivos superiores retruíram-se e inclinaram-se para lingual e o trepasse horizontal apresentou melhora significante.

No mesmo ano, ROCK ${ }^{110}$ adaptou uma mola do tipo Coffin nos aparelhos que associam placas removíveis à tração extrabucal, para prevenir o cruzamento da mordida na região posterior, a medida que os molares superiores são distalizados.

Foram incorporados ao "splint" de THUROW ${ }^{124}$ um parafuso expansor para ajustes laterais e um arco vestibular para pequenos movimentos de inclinação dos incisivos superiores, por HENRIQUES et. al. ${ }^{64}$, em 1991. Foram utilizados também grampos de Adams para melhorar a retenção e o arco extrabucal foi inserido na região dos pré-molares. Convencionaram chamar este aparelho de AEB conjugado e com ele obtiveram um efeito de restrição do deslocamento maxilar, traduzido por uma diminuição do ângulo SNA e manutenção do seu comprimento efetivo. Houve um avanço da mandíbula para anterior, mostrando um aumento do ângulo SNB e do seu comprimento efetivo. Os incisivos superiores inclinaram-se para lingual, enquanto os incisivos inferiores vestibularizaram-se moderadamente. 0 controle vertical pôde ser demonstrado pelas alterações insignificantes no padrão de crescimento e no pequeno aumento observado da altura facial ântero-inferior.

No mesmo ano (1991), HENRIQUES; FREITAS; SANTOS PINTO ${ }^{67}$ apresentaram um caso clínico de correção de uma má oclusão de Classe II, 1a divisão utilizando o AEB conjugado, demonstrando principalmente o tratamento ortopédico dos problemas esqueléticos, durante a fase de crescimento. A 
paciente com 8 anos de idade exibia cefalometricamente, um perfil ósseo convexo, crescimento vertical, incisivos superiores e inferiores vestibularizados e um ângulo nasolabial normal. A relação maxilomandibular apresentava-se deficiente mas a mandíbula encontrava-se bem posicionada, os comprimentos efetivos da maxila e da mandíbula normais, porém a altura facial ântero-inferior estava aumentada. Os valores cefalométricos obtidos após o tratamento revelaram que a má oclusão foi corrigida em decorrência da redução da velocidade de crescimento maxilar, enquanto as demais estruturas do complexo craniofacial mantiveram seu curso normal de desenvolvimento. A maxila teve seu comprimento efetivo aumentado (Co-A) durante todo o período do tratamento, porém o comprimento mandibular efetivo aumentou ainda mais (Co-Gn), resultando com isso uma redução significativa do ângulo ANB. No sentido vertical, um ligeiro aumento do ângulo do plano palatino e da altura facial ântero-inferior foi constatado, porém o ângulo do plano mandibular com a base do crânio diminuiu, exibindo tendência de rotação no sentido anti-horário.

Dois anos depois (1993), em sua tese de livre docência, HENRIQUES ${ }^{63}$ comparou o AEB conjugado com outros dois tipos de aparelhos de tração extrabucal. A amostra constou de 75 jovens divididos em três grupos de 25 cada: grupo I tratado com ancoragem extrabucal cervical, grupo II tratado com AEB conjugado e grupo III tratado com ativador associado à ancoragem extrabucal. Os resultados demonstraram restrição significante do crescimento da maxila nos três grupos, crescimento discreto da mandíbula nos grupos I e II e crescimento significante no grupo III, o que levou à diminuição do ângulo ANB, melhorando a relação maxilomandibular. Concluiu que o padrão de crescimento não foi alterado, baseado no comportamento da medida SN.GoMe, apresentando apenas um pequeno aumento da inclinação do plano palatino e da altura facial ântero-inferior. Os incisivos superiores inclinaram-se para lingual e os inferiores não foram influenciados pelo tratamento. Os molares superiores distalizaram-se nos três grupos.

Em 1996, com o objetivo de estudar cefalometricamente os efeitos de um "splint" maxilar modificado combinado com uma tração extrabucal anterior 
alta, ÜNER; EROGLU ${ }^{125}$ avaliaram 13 pacientes tratados com este aparelho. Constataram uma melhora significante dos trespasses horizontal e vertical. A protrusão maxilar diminuiu enquanto que a mandíbula protruiu. Os molares superiores distalizaram-se, os inferiores mesializaram-se e os incisivos superiores inclinaram-se para vestibular. Verticalmente, a altura dentoalveolar da maxila diminuiu significantemente e o ângulo do plano mandibular não se alterou.

Com o objetivo de comparar duas modalidades de interceptação da má olcusão de Classe II, $1^{\text {a }}$ divisão, MARTINS ${ }^{88}$ em 1997 realizou uma pesquisa em que a amostra constituiu-se de 58 jovens, sendo 23 tratados com 0 aparelho extrabucal removível, 18 tratados com o bionator de Balters e 17 jovens apresentando a mesma má oclusão foram mantidos como controle. Os resultados mostraram que as duas modalidades de tratamento exibiram alterações dentoalveolares e esqueléticas diferentes. O autor relatou que no grupo tratado com o aparelho extrabucal removível houve uma restrição do crescimento anterior da maxila, com diminuição do ângulo SNA, apesar de seu comprimento efetivo ter demonstrado um ligeiro aumento; crescimento mandibular verificado tanto pelo aumento do ângulo SNB, como pelo comprimento efetivo demonstrado pela medida Co-Gn. O ângulo ANB diminuiu, resultado do crescimento diferencial entre maxila e mandíbula; o padrão de crescimento mostrou-se inalterado, enquanto a altura facial ântero-inferior aumentou. Houve extrusão e inclinação para lingual dos incisivos superiores, distalização dos molares superiores, aumentando a inclinação distal. Já os incisivos inferiores extruíram, protruíram e acentuaram a inclinação para vestibular, e os molares inferiores mesializaram e extruíram. Concluiu que as respostas mais significativas nos grupos tratados foram alterações dentoalveolares. Enquanto o aparelho extrabucal removível promoveu a correção ântero-posterior por alterações dentoalveolares na maxila, o Bionator promoveu $68 \%$ de alterações dentoalveolares e $32 \%$ de alterações esqueléticas, com um mecanismo de ação predominantemente na face inferior. 
Neste mesmo ano (1997), MALTAGLIATI ${ }^{84}$ com o objetivo de comparar as alterações dentoesqueléticas da má oclusão de Classe II, 1a divisão sem tratamento com as tratadas por dois tipos de aparelhos ortodônticos, avaliou 75 pacientes. A amostra constou de 150 telerradiografias em norma lateral, sendo uma inicial e outra final de um grupo controle (grupo 1) e de dois experimentais. Os pacientes dos grupos experimentais foram tratados com o AEB conjugado (grupo 2) e com aparelho fixo associado ao AEB cervical (grupo 3). A análise dos resultados revelou que há pouca alteração no padrão de crescimento e que a altura facial ântero-inferior aumentou em todos os grupos. Não houve melhora significante da relação maxilomandibular no grupo controle, enquanto que, nos grupos tratados, a maxila foi retruída e conseqüentemente o angulo ANB diminuiu significantemente. As alterações dentoalveolares demonstraram que o aparelho utilizado no grupo 2 (AEB conjugado) foi eficiente no controle vertical do crescimento maxilar e na extrusão dos dentes superiores posteriores e anteriores. Estes, em ambos os grupos tratados, foram movimentados para distal e lingual, respectivamente, conduzindo à uma relação molar normal e à redução do trespasse horizontal aumentado. No grupo controle, no entanto, os dentes superiores e inferiores desenvolveram-se em uma direção ânteroinferior, mantendo as características da má oclusão de Classe II, 1 divisão.

Observa-se na literatura muitos trabalhos estudando os variados efeitos do aparelho extrabucal removível, em diversos casos clínicos, principalmente no período final da década de 90 e no início deste século, sendo que a utilização destes aparelhos constitui uma alternativa para o tratamento das más oclusões de Classe II, principalmente nos casos com protrusão maxilar e/ou dentoalveolar.

Em 1997, HENRIQUES et al. ${ }^{65}$ apresentaram um caso clínico de paciente que apresentava Classe II, $1^{\text {a }}$ divisão e sobremordida profunda tratado com um aparelho removível conjugado à ancoragem extrabucal, modificado no ponto de aplicação da força extrabucal, transportando-no para uma região mais anterior, entre os incisivos laterais e caninos superiores. Com a mudança, a linha de ação da força passava à frente do centro de resistência da maxila, 
gerando um componente de intrusão da porção anterior do arco dentário. A diminuição dos valores do comprimento efetivo da maxila e do ângulo SNA, denotou uma restrição do crescimento anterior da maxila. Apesar do discreto crescimento mandibular, o ângulo ANB diminuiu, melhorando o relacionamento maxilomandibular. A sobremordida profunda foi atenuada em $1 \mathrm{~mm}$ e os incisivos superiores intruíram e vestibularizaram. O plano palatino apresentou um ligeiro aumento do ângulo com a base do crânio, interpretado como uma manifestação do padrão de crescimento do paciente.

Um artigo que enfocou muito o tratamento precoce da Classe II, $1^{\mathrm{a}}$ divisão, é o de ALMEIDA et. al. ${ }^{6}$, realizado em 1999, onde demonstraram o tratamento desta má oclusão com o aparelho extrabucal conjugado, por meio de um caso clínico, relataram as alterações obtidas com a utilização deste aparelho na fase ideal, principalmente com relação à restrição do deslocamento ântero-posterior da maxila, ressaltando as vantagens do tratamento precoce.

Alguns anos após (2001), SANTOS PINTO et. al. ${ }^{117}$ apresentaram um caso clínico portando a má oclusão de Classe II, 1a divisão tratado com o AEB conjugado. Inicialmente, o paciente apresentava a maxila protruída e a mandíbula bem posicionada em relação à base do crânio, um aumento da altura facial ântero-inferior e tendência de crescimento vertical. Quanto ao padrão dentário, os incisivos apresentavam-se bem posicionados e os inferiores protruídos na base óssea. $\mathrm{Na}$ análise facial verificou-se uma convexidade do perfil mole. Os resultados do tratamento sobre as estruturas dentárias e esqueléticas evidenciaram a correção da má oclusão por meio da restrição do crescimento maxilar no sentido ântero-posterior e vertical, crescimento mandibular mais para frente que para baixo (rotação anti-horária) e controle de erupção dos molares e dos incisivos.

Os efeitos do aparelho extrabucal conjugado no tratamento da má oclusão de Classe II, $1^{\text {a }}$ divisão sobre o complexo dento-esquelético-facial 
foram destacados por ALMEIDA et al. ${ }^{3}$ por meio de um caso clínico, em 2002. As medidas cefalométricas iniciais da paciente mostrava uma maxila protruída, suave deficiência mandibular e uma discrepância maxilomandibular acentuada. Os incisivos superiores e inferiores encontravam-se vestibularizados e protruídos. Após o tratamento evidenciou-se uma restrição do crescimento anterior da maxila, bem como a liberação do crescimento mandibular, proporcionando a correção na relação sagital das bases ósseas. Os incisivos superiores e inferiores foram inclinados para lingual e o ângulo nasolabial aumentou melhorando sensivelmente o posicionamento do lábio superior.

A efetividade da terapêutica ortodôntica em duas fases foi apresentada por ALMEIDA et al. ${ }^{5}$, no mesmo ano (2002), por meio de um caso clínico. Na primeira etapa, o paciente que estava na fase de dentadura mista tardia (segundo período transitório) utilizou o AEB conjugado para correção da discrepância na relação maxilomandibular. Numa segunda etapa, instituiu-se o aparelho ortodôntico fixo para corrigir ou melhorar o posicionamento dos dentes. Os autores afirmaram que a intervenção precoce com aparelho ortopédico mecânico objetiva a correção dos problemas esqueléticos e dentários, modificando o relacionamento maxilomandibular, bem como movimentando os dentes para suas posições ideais nas bases ósseas, buscando um bom perfil facial.

Neste mesmo ano (2002), WHEELER et al. ${ }^{132}$ avaliaram a efetividade do tratamento precoce da má oclusão de Classe II, $1^{-a}$ divisão com os aparelhos bionator e AEB com plano de mordida e compararam com um grupo não tratado. Em relação aos objetivos alcançados com o tratamento verificou-se um índice de $83 \%$ para o grupo tratado com o Bionator, $100 \%$ para o grupo AEB com plano de mordida e $14 \%$ para o grupo controle. Os autores relataram que ambos os aparelhos produzem alterações dentoesqueléticas que corrigem a má oclusão de Classe II, 1ํㅡㄹ divisão, sendo que as alterações esqueléticas são estáveis e as dentárias tendem a recidivar. Concluíram que o tratamento precoce com o AEB com plano de mordida parece ser mais efetivo que a terapêutica com o Bionator. 
JACOBS; SAWAENGKIT ${ }^{71}$ também em 2002, avaliaram a eficácia de dois aparelhos ortopédicos, Bionator e o AEB com plano de mordida, no tratamento da má oclusão de Classe II, 1a divisão. O estudo incluiu a avaliação dos pesquisadores da Universidade da Flórida (UFLORIDA) e da Carolina do Norte (UNC). Os grupos tratados foram comparados a um grupo controle não tratado. Os resultados demonstraram que $13 \%$ dos casos não tratados, $38 \%$ dos casos tratados com Bionator e 50\% do grupo de AEB com plano de mordida apresentaram correção da relação molar. Os grupos experimentais mostraram redução equivalente do ANB. Apenas 32\% dos casos não tratados apresentaram melhora na relação maxilomandibular enquanto que nos grupos tratados o índice foi de $80 \%$. Os autores observaram que o Bionator corrigiu satisfatoriamente $30 \%$ dos casos e o AEB com plano de mordida $40 \%$ da amostra.

Com base na necessidade de obter parâmetros cefalométricos de pacientes tratados com o aparelho extrabucal conjugado ("splint" maxilar) e de pacientes tratados com o aparelho Bionator, ALMEIDA-PEDRIN ${ }^{7}$, em 2003, desenvolveu sua tese de doutorado, onde estudou e acompanhou 90 jovens, divididos em três grupos, sendo o grupo 1: pacientes que apresentavam a má oclusão de Classe II, $1^{\text {a }}$ divisão e que não receberam nenhum tipo de tratamento (grupo controle); grupo 2: pacientes que apresentavam a má oclusão de Classe II, $1^{\text {a }}$ divisão e que foram tratados com o aparelho extrabucal conjugado; e grupo 3: pacientes também Classe II, $1^{\text {a }}$ divisão tratados com o aparelho Bionator de Balters. Concluiu que o deslocamento anterior da maxila foi restringido significantemente pelo tratamento com o $A E B$ conjugado; as dimensões mandibulares aumentaram sensivelmente nos grupos tratados, porém não foram considerados estatisticamente significantes; os aparelhos avaliados propiciaram uma melhora significante na relação maxilomandibular e na convexidade facial, com diminuição dos ângulos ANB e NAP; nenhum dos aparelhos produziu alterações significantes no padrão de crescimento craniofacial; o tratamento com o AEB conjugado influenciou o posicionamento dos lábios diminuindo a protrusão, até os níveis de normalidade, tanto do lábio superior como do inferior. 
Também em 2003, outro trabalho enfatizando o controle da dimensão vertical com o aparelho removível conjugado à ancoragem extrabucal no tratamento da Classe II, $1^{\mathrm{a}}$ divisão foi desenvolvido por HENRIQUES et. al. ${ }^{60}$. Os autores explicaram que o aparelho removível conjugado à ancoragem extrabucal, pode ser utilizado na fase da dentadura mista tardia, no intuito de promover a normalização da relação entre as bases ósseas e obter estabilidade esquelética, dentária e facial no final do tratamento, já que as más oclusões de Classe II, $1^{\mathrm{a}}$ divisão com padrão de crescimento vertical, protrusão maxilar e/ou dentoalveolar apresentam um comprometimento da estética facial. Nestes casos, observa-se a rotação horária da mandíbula e aumento da dimensão vertical anterior.

Assim como no artigo anterior ${ }^{60}$, no intuito de estudar as alterações verticais ocorridas em pacientes submetidos ao uso do aparelho removível conjugado ao extrabucal, PIRES, et. al. ${ }^{101}$ desenvolveram um trabalho em que analisaram dois diferentes pontos de aplicação da força: anterior e posterior. $O$ estudo desenvolveu-se por meio de teleradiografias iniciais e finais de dez pacientes controle (sem tratamento) (grupo I), dez pacientes tratados com o aparelho removível conjugado ao extrabucal com aplicação da força na região posterior (grupo II) e dez pacientes tratados com o aparelho removível conjugado ao extrabucal com aplicação da força na região anterior (grupo III). O grupo I mostrou posicionamento inferior do plano palatino, tendendo à rotação horária, no grupo II, observou-se deslocamento para baixo do ponto ENA. No grupo III ocorreu mínima alteração do ângulo SN.PP e tendência de constância do ponto ENA. Concluem que estes resultados sugerem que portadores de má oclusão de Classe II, $1^{\text {a }}$ divisão, sem tratamento, apresentam deslocamento para baixo da porção anterior maxilar, e que o grupo que utilizou o aparelho removível conjugado ao extrabucal com ponto de aplicação da força na região posterior apresentou alterações similares às do grupo controle, possibilitando raciocinar que a correção da mordida aberta anterior, associada à má oclusão de Classe II, seria beneficiada por este aparelho. Já o aparelho removível conjugado ao extrabucal com ponto de aplicação da força na região anterior trataria a má olcusão de Classe II com sobremordida profunda, pois os resultados sugerem maior controle vertical maxilar. 
Também no intuito de demonstrar os efeitos e resultados obtidos com a utilização do aparelho removível conjugado ao extrabucal em tratamentos da má oclusão de Classe II, $1^{\text {a }}$ divisão, principalmente quando comparado com o AEB com inserção no tudo dos primeiros molares, NOUER et. al. ${ }^{98}$, em 2004 , apresentaram um trabalho relatando dois casos clínicos, cada um tratado com o aparelho especificado, e concluíram que o aparelho AEB conjugado permite um bom controle no sentido antero-posterior, vertical e transversal da maxila, além do redirecionamento e liberação do crescimento mandibular.

\subsubsection{CONCLUSÃO DOS ARTIGOS REFERENTES AO TRATAMENTO DA MÁ OCLUSÃO DE CLASSE II, $1^{\text {a }}$ DIVISÃO, COM O APARELHO EXTRABUCAL CONJUGADO:}

Os trabalhos relacionados ao uso do aparelho extrabucal conjugado (Splint maxilar) não são muitos, sendo que desde THUROW ${ }^{124}$, em 1975, até o presente momento, o aparelho extrabucal conjugado ao aparelho removível sofreu várias modificações, como as confirmadas por HENRIQUES et. al. ${ }^{64}$, em 1991, onde acrescentaram um parafuso expansor para ajustes laterais e um arco vestibular para pequenos movimentos de inclinação dos incisivos superiores.

O aparelho extrabucal conjugado ao aparelho removível apresenta-se com sua indicação principalmente no diagnóstico de protrusão maxilar e/ou dentoalveolar. Observando os efeitos deste aparelho, verifica-se que a desoclusão promovida pelo recobrimento oclusal, facilita tanto a movimentação dentária, como a correção de deslocamentos funcionais da mandíbula porque elimina as interferências existentes. Esse recobrimento possibilita ainda uma distribuição uniforme da força por todo o arco dentário, promovendo um controle vertical eficiente. Como resultado, obtém-se uma distalização dos dentes posteriores, um controle de inclinação dos dentes anteriores conforme são deslocados para lingual e, a inclinação distal dos caninos. Observa-se também uma restrição do deslocamento ântero-inferior do complexo maxilar, com conseqüente restrição da rotação mandibular no sentido horário. 


\subsection{TRATAMENTO DA CLASSE II, $1^{\mathrm{a}}$ DIVISÃO COM O USO DO APARELHO EXTRABUCAL DE TRAÇÃO OCCIPITAL}

Um sucinto histórico do aparelho extrabucal de tração occipital será realizado:

O uso de força extrabucal surgiu no inicio do século $X I X$, quando CELLIER $^{37}$ verificando a necessidade de desenvolver um dispositivo de ancoragem extrabucal para prevenir a luxação da mandíbula durante as extrações dentárias, deu início à utilização deste aparelho.

KINGSLEY ${ }^{77}$, em 1875, foi o pioneiro a utilizar forças extrabucais com finalidade ortodôntica. Popularizou a utilização da ancoragem occipital, seguido logo depois por FARRAR ${ }^{47}$, que em 1886 a utilizou para retração dos dentes ântero-superiores.

BAKER $^{15}$ em 1893, introduziu o uso de elásticos intermaxilares, nos quais os elásticos uniam o arco superior ao arco inferior. Surgiu então a chamada ancoragem intermaxilar que se tornou muito popular nesta época.

Os aparelhos extrabucais perderam a sua ação de maneira tão abrangente por aproximadamente quatro décadas, com a aceitação da maneira de tratar proposta por Angle (não extracionista), somada à ancoragem intermaxilar de Baker.

Por meio de OPPENHEIM ${ }^{99}$, na Europa e BRODIE ${ }^{31}$ nos EUA, na década de 30, o aparelho extrabucal foi introduzido nos tratamentos novamente, após este longo período de desuso, evidenciando principalmente seus efeitos ortodônticos e ortopédicos.

O tratamento ortopédico mecânico das más oclusões de Classe II, $1^{\mathrm{a}}$ divisão, é definido pelas resultantes de forças aplicadas sobre os dentes e 
transmitidas aos ossos subjacentes, redirecionando o crescimento do complexo craniofacial. Nestes casos, a melhora no relacionamento espacial maxilomandibular provém da aplicação planejada de dispositivos mecânicos, exemplificados pela utilização de elásticos ${ }^{15,37,39}$, nas trações maxilares extrabucais, para a liberação de forças necessárias às alterações dentoesqueléticas $^{16,49}$.

Desde o início do século passado inúmeros relatos científicos e clínicos, analisando os efeitos dentoesqueléticos e tegumentares de diferentes tipos de aparelho extrabucal nas correções das más oclusões de Classe II, $1^{\text {a }}$ divisão são datados com entusiasmo, pelo professor Albin Oppenheim ${ }^{99}$, principalmente quando divulgou os benefícios da sua aplicação, caracterizando-o como o melhor método ortodôntico na movimentação dentária, após um período de estagnização em decorrência da preferência pelos elásticos intermaxilares, como comentado anteriormente ${ }^{15,37,39}$. Devido à necessidade de descobertas à respeito de suas comprovações científicas, de sua mecânica de ação, bem como a rotineira aplicação clínica do aparelho extrabucal, a mantém, de modo imbatível como opção de tratamento.

Com o intuito de investigar as alterações dentoesqueléticas induzidas em más oclusões de Classe II, $1^{\mathrm{a}}$ divisão, com a utilização de forças extrabucais, EPSTEIN ${ }^{46}$, em 1948, realizou um trabalho em que a amostra compôs-se de 12 pacientes não tratados ortodonticamente entre cinco e 18 anos de idade e 12 pacientes, entre seis e 10 anos de idade no início da terapia, tratados apenas com o aparelho Extrabucal de tração média por 13 meses aproximadamente. Os resultados mostraram um movimento no sentido ântero-inferior dos molares superiores, em condição normal de crescimento seguindo a tendência natural do comportamento maxilar, enquanto que os molares que receberam a tração foram movimentados em sentido posterior em relação à maxila. Não se evidenciou um movimento no sentido anterior dos molares inferiores nos casos tratados. Concluiu-se que a mecânica abordada foi efetiva na correção molar das Classes II, com restrição do movimento natural dos primeiros molares superiores e que o sucesso do tratamento 
depende fielmente das mudanças individuais do crescimento e desenvolvimento e da cooperação do paciente.

POULTON ${ }^{103}$ em 1959, estudou um grupo que constava de 29 pacientes em fase de dentição mista, com má oclusão de Classe II, $1^{\mathrm{a}}$ divisão de Angle, que foi tratado com aparelho extrabucal occipital com gancho nos incisivos centrais e comparou-o a um grupo com o mesmo tipo de má oclusão, que não recebeu qualquer tipo de tratamento, e concluiu que no grupo tratado houve alguma inibição do crescimento anterior da maxila e um leve aumento da altura facial inferior.

Este mesmo autor, POULTON ${ }^{104}$, perante a necessidade de maiores estudos à respeito das terapias ortodônticas com o uso do aparelho extrabucal, em 1964, comparou cefalometricamente os efeitos dento-esqueléticos de pacientes com más oclusões de Classe II, $1^{\text {a }}$ divisão, que foram tratados por três anos com o aparelho Extrabucal de tração occipital. Vinte e duas telerradiografias foram selecionadas para o grupo experimental, com a idade inicial média de 10,33 anos, comparadas com um grupo controle, sem ter sido submetido à intervenção ortodôntica. Baseado nos dados obtidos, constatou-se que a média de distalização dos molares superiores em um ano de tratamento foi de $2 \mathrm{~mm}$ e em dois anos, 0,8mm. Entretanto, em três anos de terapia, evidenciou-se em média uma mesialização de 0,9mm. Por outro lado, no grupo controle, a mesialização foi diagnosticada por todo o período de observação nos molares e incisivos superiores, deteriorando a relação de Classe II existente. O autor conclui que os molares e os incisivos superiores, em período ativo de tratamento, continuam a mesializar acompanhando o crescimento natural da maxila, porém de uma forma menos veloz quando comparada a períodos semelhantes sem intervenção mecanoterápica. Adicionalmente, o autor destacou a importância em se direcionar corretamente a aplicação da força extrabucal para o controle dos movimentos dentários.

Assim como POULTON ${ }^{104}$, em 1964, dois anos após, BAALACK; POULSEN ${ }^{13}$, também realizaram um trabalho onde examinaram os benefícios da tração occipital, utilizada por um ano com uma força média de 500 gramas 
por lado, em nove meninos e 20 meninas, com a idade inicial média de 11 anos, apresentando a má oclusão de Classe II. Utilizaram-se de 22 pacientes apresentando a mesma má oclusão, mediante as análises em modelos ortodônticos de estudo, constataram que o tratamento por meio da tração occipital contribuiu para uma melhora no relacionamento molar do que propriamente para uma distalização efetiva dos molares superiores. Os autores atribuem esse achado como conseqüência da mesialização inibida desses dentes em combinação com o crescimento da mandíbula em sentido anterior. Observou-se também uma redução suave na sobressaliência, atribuindo-a ao crescimento da mandíbula em direção anterior em conexão com a obtenção de uma oclusão mais estável. Relacionaram o prognóstico da distalização dos primeiros molares superiores a um início de tratamento anterior à erupção dos segundos molares superiores, à condição de espaço adequada no arco inferior e ao espírito de cooperação durante o tratamento.

Ainda na década de 60, outro autor, INTERLANDI ${ }^{70}$ em 1969, apresentou o caso clínico de um paciente onde planejou um tratamento com extrações dos primeiros pré-molares superiores, bandagem total para a técnica de Edgewise, aparelho extrabucal de Interlandi (IHG) e mecânica de Classe II. Após o tratamento, o autor concluiu que as diferenças entre os valores cefalométricos iniciais e finais eram bastante expressivas, principalmente com relação à distalização dos molares superiores, e a restrição no deslocamento ântero-posterior da maxila. Relatou ainda a restrição na extrusão dos primeiros molares superiores.

Na década de 70, mais especificamente em 1972, WATSON ${ }^{131}$, com o objetivo principal de determinar os efeitos do tratamento com o aparelho extrabucal de tração occipital, analisou 14 pacientes, sendo 12 do gênero feminino e dois do masculino, entre as idades de seis a 10 anos, com tomadas radiográficas adquiridas em três diferentes períodos, durante o tratamento, que se procedeu por dois anos. Aplicou-se uma magnitude média de força de 600 gramas por lado e tentou-se coincidir a linha de ação com o centro de resistência do molar. Os resultados a seguir foram obtidos em média por ano: 0 eixo facial foi aberto em $0,03^{\circ}$, evidenciando um bom controle sobre a direção 
de crescimento; a convexidade facial reduzida em 1,5mm (medida linear nesta análise); a relação molar e a sobressaliência foram reduzidas em $3 \mathrm{~mm}$, com movimento de corpo do molar e controle da inclinação dos incisivos; a altura facial ântero-inferior diminuiu em $0,72^{\circ}$ (medida angular nesta análise), mesmo com o palato sendo inclinado inferiormente na região anterior; a posição do molar superior foi reduzida em 2,22mm; os molares superiores foram intruídos, com inclinação superior do plano oclusal na região posterior; os ângulos S.N.A e S.N.B foram diminuídos em $1,94^{\circ}$ e em $0,28^{\circ}$, respectivamente; e o ângulo SN.GoGn diminuiu em $0,44^{\circ}$. O autor citou inúmeras vantagens em se tratar precocemente os pacientes com esta mecanoterapia e enfatizou ser 0 crescimento útil mas não essencial durante o seu tratamento ativo.

Também analisando cefalometricamente os efeitos produzidos pelo uso do aparelho extrabucal, como já estudado anteriormente ${ }^{103}$, e acrescentando o estudo histológico destes efeitos, ELDER; TUENGE ${ }^{45}$, em 1974, utilizaram seis macacos (Macaca mulatta), na fase de dentadura mista, sendo dois desses designados como macacos controles, sem nenhuma intervenção ortodôntica. Aplicou-se uma força de 700 gramas por lado, direcionada a $40^{\circ}$ do plano oclusal, em esplintes metálicos conectados ao arco superior, com verificações periódicas para a manutenção da magnitude e direção da força aplicada. Após um período experimental de 71 dias e de observação de 63 dias, clinicamente se evidenciou uma mudança notável no perfil de Classe I para a Classe III nos animais submetidos à mecanoterapia. Com a colocação de implantes metálicos, associada à sobreposição de traçados cefalométricos, constataramse, nos animais tratados, as seguintes alterações: um reposicionamento da maxila e elementos dentários para superior e posterior, com o ponto $A$ deslocado para posterior; uma rotação em sentido anti-horário da mandíbula, com diminuição do ângulo do plano mandibular; e um alongamento da cabeça do côndilo. Esses resultados cefalométricos foram praticamente o inverso dos resultados encontrados no grupo controle. A sutura zigomaticotemporal foi extremamente influenciada com a terapia, sendo reabsorvida 17 vezes a mais que em condição normal e a sutura zigomaticomaxilar foi alterada de uma condição de deposição para uma condição de reabsorção. Não se observaram mudanças nas suturas zigomaticofrontais, ou suturas frontomaxilares. As 
condições histológicas confirmaram as respostas suturais e a movimentação para distal e vestibular dos dentes superiores. Este estudo provou que, com a aplicação de forças extrabucais, não somente os dentes são afetados, mas toda a maxila e os ossos do terço médio da face, mediado por reabsorções nas articulações da maxila. Foi evidente, com a aplicação do aparelho Extrabucal, a inibição do crescimento maxilar normal e o seu deslocamento em sentido posterior e superior, e que o movimento distal encontrado nos molares inferiores foi em decorrência da transmissão das forças distais oriundas do arco superior para o arco inferior.

Outro trabalho realizado também com animais e analisado de forma cefalométrica e histologicamente, um ano após ao anterior ${ }^{45}$, (1975), foi o de MELDRUM ${ }^{92}$, visando principalmente avaliar os efeitos do emprego da tração extrabucal sobre o padrão de crescimento esquelético facial superior, que se direciona para a inferior e para a anterior em situações normais. Estudou quatro macacos (Macaca mulatta), submetidos à mecânica extrabucal de tração occipital. Designaram-se três animais como grupo experimental e um animal, como controle, com uma idade aproximada à humana entre seis e sete anos. Para a aplicação da força sobre o arco superior, utilizou-se um esplinte metálico cimentado sobre os dentes superiores, em que se empregou uma magnitude de força, por lado, de 300 gramas, durante um período de 81 a 89 dias, com a linha de ação da força em média de $40^{\circ}$ com o plano oclusal. Os dados cefalométricos (com o auxílio da implantação de implantes) e os histológicos sugeriram que o aparelho extrabucal desacelerou, ou mesmo reverteu, o padrão normal de deslocamento facial superior, atribuindo a essa terapia a possibilidade de prevenir o movimento para frente e para baixo da maxila em período de crescimento. Quase todos os implantes faciais nos animais foram deslocados para cima e para trás relativos à base craniana. As maiores alterações ortopédicas foram vistas no osso maxilar, comparado com o frontal, temporal e o zigomático, já que os dentes em que a força era aplicada estão contidos nesse osso. O plano palatino foi deslocado superiormente e rotacionado em sentido anti-horário em todos os componentes experimentais, o que surpreendeu o autor, acompanhando o movimento dos esplintes em mesmo sentido. Atribuiu-se este movimento do esplinte ao movimento dentário 
e à remodelação sutural e óssea do complexo esquelético facial superior. Não se constatou movimento de corpo dos dentes superiores.

Não estudando diretamente e isoladamente os efeitos do uso da tração occipital, mas sim analisando-a em conjunto com a tração cervical, em 1976, CHACONAS; CAPUTO; DAVIS ${ }^{38}$, objetivaram determinar a natureza das forças transmitidas às estruturas craniofaciais destes dois métodos de tração extrabucal, já que na época havia um conflito de idéias quanto às suas reais implicações. Para realizar este estudo, utilizaram modelos tridimensionais reproduzidos de crânios humanos com materiais birrefringentes para simular osso, dentes e ligamento periodontal. Forças de 1.250 gramas em cada lado foram transmitidas através de um aparelho e observações foto-elásticas do estresse desenvolvido nos modelos eram checados. Os dados obtidos mostraram que algumas áreas anatômicas sofreram ação por ambas as trações, como o processo pterigóide do osso esfenóide, o arco zigomático, a junção do osso maxilar com o lacrimal e com o processo orbitário do etmóide e ao redor dos molares superiores. Algumas estruturas, por sua vez, sofreram ação dependendo da tração utilizada. Por exemplo, a cervical estimulou reações no processo frontal da maxila, na sutura zigomaticofrontal e na junção dos ossos palatinos e a occipital, na junção anterior da maxila (região inferior à espinha nasal anterior - ao redor do ponto cefalométrico A). Os resultados mostraram que ambas as ativações produziram forças ao redor dos dentes e à distância nas estruturas craniofaciais, sendo este último o achado de maior importância extraído desse estudo. De particular interesse clínico, a tração cervical desencadeou inclinações extensas nos primeiros molares superiores. Como a intensidade das forças aplicadas foi maior quando da aplicação da tração cervical e por ela também ter repercutido em mais áreas, os autores concluem que as mudanças ortopédicas com essa tração é maior que com a occipital.

Outro trabalho que também utilizou como metodologia de estudo o aparelho extrabucal com tração cervical e occipital, assim como o anterior ${ }^{38}$, foi o de SCANAVINI ${ }^{120}$, realizado em 1976, em que comparou pacientes que foram tratados com aparelho extrabucal com apoio occipital (IHG), a pacientes 
que usaram aparelho extrabucal com apoio cervical (KHG), e concluiu que, as modificações no padrão esquelético da face, em áreas distanciadas do ponto de aplicação da força extrabucal, não eram diferentes para os grupos que foram estudados, e que os resultados não permitiram determinar maior efetividade a nenhum dos aparelhos empregados.

Dois anos após (1978), outro estudo à respeito da aplicação do aparelho extrabucal, foi o de BROWN ${ }^{32}$, realizado em pacientes que encontravam-se na fase de dentadura mista tardia ou no início da permanente. Avaliou a aplicação intermitente (de 12 a 16 horas por dia) da força extrabucal suave (entre 200 a 600 gramas por lado). A amostra compreendeu 11 meninas e seis meninos utilizando a tração occipital (força direcionada para cima e para trás), com uma idade inicial média de 13,7 anos e 13 meninas e sete meninos utilizando a tração cervical (força direcionada para baixo e para trás), com uma idade inicial média de 13,1 anos. Selecionou-se também um grupo controle sem qualquer intervenção mecanoterápica, porém em menor número que o experimental e com uma idade inicial média de 11,9 anos. Mediante os resultados cefalométricos após um ano de tratamento, ao se compararem os grupos experimentais com o grupo controle, verificou-se que a tração cervical promoveu uma redução dos ângulos SNA e ANB, uma inclinação da maxila e da mandíbula para baixo e para trás, extrusão dos molares superiores e uma inclinação no sentido horário do plano palatino. O aumento da altura facial anterior e da angulação do plano mandibular nos pacientes tratados foram provavelmente decorrentes da extrusão dos molares superiores. A tração occipital, por outro lado, favoreceu apenas extrusão dos molares inferiores, porém não se constatou um aumento na altura facial ântero-inferior. Concluiuse que é de extrema importância a seleção correta dos aparelhos extrabucais, pois quando o crescimento no sentido vertical é julgado ser adequado ou excessivo, visto pelas mensurações da altura facial anterior, do plano mandibular ou da erupção vertical dos molares superiores, a tração occipital é a terapia de escolha. Já em casos com características opostas, aplica-se a tração cervical encorajando o desenvolvimento craniofacial no sentido vertical. 
Neste mesmo ano, BAUMRIND; MOLTHEN; WEST; MILLER ${ }^{22}$ investigaram a ação sobre a maxila de cinco tipos de modalidades terapêuticas, incluindo forças ortopédicas mecânicas e funcionais, com o objetivo de avaliar as alterações induzidas no plano mandibular. Duzentos e quarenta e nove pacientes com más oclusões de Classe II compuseram a amostra, sendo divididos de acordo com o aparelho utilizado, num tempo médio de tratamento de 24 meses. Em específico, o grupo experimental tratado com o aparelho Extrabucal de tração occipital compôs-se de 53 pacientes, sendo 19 do gênero masculino e 34 do feminino, com a idade inicial média de 8,85 anos e o grupo controle, para comparação com todos os grupos experimentais, compôs-se de 54 pacientes, com a idade inicial média de 8,44 anos. De acordo com os resultados alcançados a curto prazo, obteve-se a correção da relação molar com a utilização de todos os aparelhos, enquanto que no grupo controle essa relação permaneceu inalterada. Verificou-se que o plano mandibular no grupo controle mostrou uma tendência em diminuir durante o período de observação, enquanto que nos grupos experimentais, mesmo com um suave aumento, não se alterou de modo estatisticamente significante. Os autores asseguraram esse comportamento devido à seriedade com que os profissionais trataram esses pacientes, impedindo com que a mandíbula rotacionasse de modo exagerado.

Foi dado prosseguimento à interpretação dos resultados obtidos na pesquisa anterior citada, com o intento de associar alguns fatores que poderiam contribuir com o aumento do ângulo do plano mandibular em casos tratados. Os mesmos autores BAUMRIND; MOLTHEN; WEST; MILLER ${ }^{22}$, constataram que, quanto maior o deslocamento do molar para a distal, maior a tendência em se abrir o ângulo do plano mandibular. Este achado implica que qualquer esforço para corrigir a relação molar, em bases não extracionistas, pela distalização dos molares superiores ou pela restrição de sua mesialização normal com o crescimento, criará condições para a abertura do plano mandibular. Verificaram também que, quanto mais os primeiros molares superiores extruírem, maior a tendência em se abrir este ângulo. 
Após um ano (1979), BRANDT; SHAPIRO; $\mathrm{KOKICH}^{30}$ propuseram delinear as possibilidades e limitações da aplicação da força extrabucal às articulações craniofaciais de animais adultos. A amostra consistiu de dois macacos (Macaca fascicularis) e de duas macacas em idade adulta entre seis e sete anos. Aplicaram-se implantes metálicos para o auxílio na interpretação cefalométrica e implantes occipitais para o auxílio na ancoragem. A direção da tração, aplicada em esplintes maxilares, foi de $30^{\circ}$ aproximadamente com 0 plano oclusal e a força exercida foi de 450 gramas por lado. A fase experimental ativa durou de 84 a 205 dias, alcançando nos animais experimentais trespasses horizontais negativos ao redor de $9 \mathrm{~mm}$. Os resultados revelaram que todos os animais apresentaram um deslocamento superior e posterior da maxila, resultando em mudanças da relação dentária normal de Classe I para Classe III. Os planos palatino e oclusal foram deslocados para posterior e para superior com uma suave rotação em sentido anti-horário. A mandíbula moveu-se posteriormente em vários graus em todos os animais, com suave diminuição do ângulo do plano mandibular e com diminuições significantes da altura vertical anterior. Os dentes superiores foram lingualizados de modo significante e os primeiros molares superiores inclinados, em relação ao plano palatino, em $14^{\circ}$. As sobreposições dos traçados demonstraram que a interação das relações dentárias com as esqueléticas, durante a fase ativa, foi em torno de 2/1. Como estabelecido que o centro de rotação do complexo dentofacial localizou-se na região superior da maxila e ossos zigomáticos, o complexo facial foi trasladado superiormente, com grandes mudanças remodeladoras observadas nas suturas zigomaticomaxilar e zigomaticotemporal, e menores mudanças na sutura zigomaticofrontal, como constatado histologicamente. O estudo confirmou que a força extrabucal direcionada posteriormente sobre a maxila, em animais adultos, resultou em alterações dramáticas na morfologia das suturas e no relacionamento espacial da maxila.

Após dois anos (1981), e utilizando-se da mesma metodologia aplicada nas pesquisas anteriores, BAUMRIND; KORN; MOLTHEN; WEST ${ }^{21}$ e BAUMRIND; KORN ${ }^{19}$, continuaram a estudar os efeitos sobre o terço inferior da face, a partir da aplicação de forças de retração na maxila. Verificaram um 
aumento expressivo da medida Co-Pog principalmente nos pacientes tratados com aparelhos ortopédicos funcionais e uma redução na velocidade de incremento da altura facial ântero-inferior no grupo experimental com a utilização da tração occipital, comparado ao grupo controle, enquanto que a velocidade de incremento da altura facial anterior total permaneceu inalterada. Em geral, os autores aconselharam a não-utilização da tração cervical em pacientes com altura facial ântero-inferior aumentada.

Dois anos após (1983), no intuito de identificar e quantificar os componentes ortodônticos e ortopédicos do deslocamento dos primeiros molares superiores e da ENA (espinha nasal anterior) com a utilização de diferentes sistemas de tratamento, BAUMRIND; KORN; ISAACSON; WEST; MOLTHEN $^{20}$, selecionaram 238 pacientes, na dentadura mista, com más oclusões de Classe II. Cinqüenta pacientes compuseram o grupo controle, enquanto que os demais, 188 pacientes, compuseram os grupos experimentais, divididos de acordo com a terapia aplicada (aparelho Extrabucal de tração cervical com a aplicação de forças leves; aparelho Extrabucal de tração occipital com a aplicação de forças pesadas; e o aparelho Ativador com forças bem leves). Os resultados demonstraram que, no grupo controle, o plano palatino permaneceu inalterado, os molares superiores mesializaram e extruíram aproximadamente $3 \mathrm{~mm}$ e as coroas inclinaram para mesial, em torno de $1 \mathrm{~mm}$ a mais que as raízes durante o processo de erupção. Com a tração cervical, o deslocamento anterior da ENA foi expressivamente reduzido ao se comparar com o grupo controle. Analisando a efetividade da tração occipital, os autores verificaram que os molares superiores foram deslocados para superior e para posterior aproximadamente $2,5 \mathrm{~mm}$ e suas coroas foram inclinadas para distal 2,50 em relação às suas raízes, afirmando ser a terapia de maiores mudanças na região desses dentes e em menor tempo de tratamento. Os efeitos com o aparelho Ativador foram menores em magnitude comparados aos outros aparelhos. De maneira geral, os autores constataram que a utilização de forças para a retração da maxila produz efeitos substanciais nesse osso, tanto de natureza ortodôntica como de natureza ortopédica. Para surpresa dos autores, verificaram que com a aplicação de forças pesadas (tração occipital), as alterações de natureza ortodôntica foram mais evidentes que as alterações 
ortopédicas, e que com a tração cervical, o efeito inverso se manifestou, mostrando um efeito ortodôntico menor que o ortopédico. Com o Ativador, em que se empregou a menor força, os efeitos foram divididos igualmente. Os autores concluíram que forças mais pesadas tendem a deslocar os dentes enquanto que forças mais leves tendem a deslocar a matriz óssea como todo.

Outro trabalho que propôs-se a avaliar os efeitos dentoesqueléticos em pacientes com más oclusões de Classe II, $1^{\mathrm{a}}$ divisão, na fase de dentadura mista, foi o de RIGHELLIS ${ }^{109}$, também em 1983. Estudaram os efeitos promovidos por quatro tipos de parelhos ortopédicos: o Ativador de Andresen, o Regulador funcional de Fränkel, o Extrabucal de tração occipital e o de tração cervical. Ao se compararem os resultados cefalométricos obtidos dos grupos experimentais com os dados provenientes de um grupo controle, verificaram que todas as modalidades terapêuticas corrigiram a relação molar existente de Classe II e que se diferenciaram quanto aos efeitos no complexo craniofacial. $O$ Aparelho Extrabucal de tração occipital desencadeou o maior efeito retrusivo na posição do ponto $A$, no sentido ântero-posterior, em relação aos demais aparelhos. Quanto à altura facial ântero-inferior, estabeleceu-se que as mudanças nessa dimensão, decorrentes dos vários métodos de tratamento, são altamente variáveis para uma predição confiável, necessitando de uma avaliação clínica regular para o monitoramento de qualquer alteração indesejável. A variabilidade interindividual foi o aspecto mais importante nos achados deste estudo, devendo haver, por parte dos ortodontistas, um conhecimento imprescindível do crescimento e desenvolvimento normal dos maxilares.

Um trabalho desenvolvido à partir de crânios humanos, na década de 80, mais especificamente em 1986, foi o de KRAGT; DUTERLOO; ALGRA ${ }^{80}$, sendo que avaliaram oito crânios humanos macerados, com uma média de idade aproximada em 9,5 anos, submetidos a um sistema de tração extrabucal occipital. Os efeitos observados por esse estudo evidenciaram deslocamentos dos componentes craniofaciais, com a maxila, predominantemente, deslocada em direção posterior e pouco ou nenhum deslocamento desse osso em direção superior vertical. Em conclusão, demonstrou-se que crânios humanos 
macerados podem servir como modelos sob cargas em experimentos, e que nem sempre o deslocamento da maxila e outros ossos se concretizam na mesma direção das forças aplicadas, sendo influenciado pela morfologia craniofacial e relacionamento intersutural.

Outra pesquisa também muito importante, mas que não especifica seus estudos essencialmente no aparelho extrabucal de traço occipital, e sim compara-o com o de tração cervical, assim como trabalho anteriormente citados $^{38,120}$, é o de BOECLER et. al. ${ }^{28}$, realizado em 1989, em que os autores estudaram 200 pacientes, os quais foram tratados ortodonticamente de três maneiras: um grupo com aparelho extrabucal com tração cervical, outro com aparelho extrabucal com tração combinada (combinação de força occipital e cervical), e outro grupo que não usou aparelhos extrabucais, e concluiu que tanto o aparelho extrabucal cervical como o combinado reduziram a discrepância de Classe II, e que não houve diferença significante na média de mudanças produzidas por aparelho extrabucal combinado ou cervical.

Já na década de 90, especificamente em 1992, FIROUZ; ZERNIK; NANDA $^{49}$, propuseram investigar as mudanças dentárias e esqueléticas produzidas pelo aparelho extrabucal de tração occipital tipo Interlandi, utilizando forças de baixa magnitude (500 gramas por lado), na correção das más oclusões de Classe II. Selecionaram-se 24 pacientes com as idades esqueléticas variando entre 9,5 e 12,5 anos, com o espaço interlabial de $2 \mathrm{~mm}$ no mínimo e com uma altura facial ântero-inferior aumentada. Entretanto, apenas 12 pacientes receberam a mecanoterapia, tendo os demais como grupo controle. Direcionou-se a força, liberada pelo elástico (trocado diariamente), para cima e para trás passando aproximadamente pelo centro de resistência dos primeiros molares superiores, com uma angulação, relativa ao plano oclusal, ao redor de $20^{\circ}$. Adicionalmente à força extrabucal, empregou-se uma barra transpalatina com a função de prevenir rotação dentária, simetria de movimentação entre os lados e manter a distância intermolar. As radiografias cefalométricas de norma lateral foram tomadas ao início e seis meses após o tratamento. Perante os resultados cefalométricos, observou-se que, em seis meses de tratamento com um uso diário do aparelho de 12 horas em média por 
dia, as mudanças mais significantes foram nos primeiros molares superiores. Esses dentes foram deslocados para a distal $(X=2,56 \mathrm{~mm})$ e intruídos $(X=$ $0,54 \mathrm{~mm}$ ) enquanto que, no grupo controle, eles mesializaram ( $X=0,23 \mathrm{~mm}$ ) e erupcionaram ( $X=0,42 \mathrm{~mm}$ ). Logo, os molares superiores foram deslocados de acordo com a direção da força extrabucal aplicada e o movimento distal foi de translação contribuindo para a correção da relação molar de Classe II. Mudanças esqueléticas significantes também foram observadas na base apical superior, ou seja, o aparelho não só restringiu ou redirecionou o crescimento ântero-posterior da maxila como exerceu um efeito ortopédico movimentando-a distalmente. Concluiu-se neste estudo que a utilização da força extrabucal, de modo intermitente, pode também corrigir de maneira eficaz a relação molar de Classe II em um período curto de tempo.

No mesmo ano, BURKE; JACOBSON ${ }^{33}$ estudaram as alterações esqueléticas no sentido vertical de pacientes com más oclusões de Classe II, divisão 1, que apresentavam inicialmente o ângulo do plano mandibular aumentado, tratados com o aparelho extrabucal de tração cervical e com 0 aparelho extrabucal de tração occipital. Selecionaram-se 32 pacientes para comporem a amostra de tração occipital, com a força direcionada em 10 a $12^{\circ}$ em relação ao plano oclusal e 21 pacientes para compor a amostra de tração cervical, com a força direcionada paralela ao plano oclusal. Todos os pacientes se encontravam em fase de crescimento e três medidas foram estabelecidas para avaliar o comportamento do plano mandibular (SN.GoGn; SN.GolnMe; SN.PM). Um dos mais importantes achados cefalométricos deste estudo foi a ausência de grandes diferenças quanto às alterações no ângulo do plano mandibular decorrentes dos dois tipos de aplicação de força. Confirmou-se a extrusão dos molares superiores quando da utilização da tração cervical, porém não se verificou alteração no sentido vertical da face inferior. Os molares inferiores não foram alterados por ambas modalidades terapêuticas, evidenciando que o tipo de tração e o desenvolvimento vertical dos molares superiores parecem não interferir no desenvolvimento dento-alveolar inferior. Ocorreu uma diminuição significante do ângulo do plano oclusal nos pacientes tratados com a tração cervical, já que um adicional desenvolvimento dentoalveolar posterior vertical foi efetuado (o plano oclusal tende a inclinar para a 
inferior na região posterior). A tração occipital, por outro lado, inibiu este desenvolvimento dentoalveolar posterior vertical. No grupo tratado com a tração occipital, nenhuma correlação foi encontrada entre a medida do ângulo do plano mandibular e alterações na altura facial ântero-inferior ou na altura facial total. Em outras palavras, a altura facial ântero-inferior aumentada foi encontrada em casos onde o plano mandibular aumentou e em casos onde diminuiu. Em casos tratados com a tração cervical, por outro lado, alterações no ângulo do plano mandibular mostraram-se fortemente correlacionadas com a altura facial anterior total e com a ântero-inferior. Em ambos os grupos, principalmente com a tração occipital, as alterações na altura do molar superior (ㅁ-SN, ㅁ-PP) foram fortemente correlacionados com alterações nas variáveis da altura facial anterior. Já, nenhuma correlação significante foi encontrada entre as alterações na altura molar superior e alterações em qualquer das variáveis do ângulo do plano mandibular. Os autores acreditaram que com a inibição do desenvolvimento vertical dento-alveolar superior pela tração occipital, o desenvolvimento vertical dento-alveolar inferior seria encorajado na maioria dos casos, explicando a forte correlação entre a altura molar inferior e as variáveis da altura facial posterior. Os autores sugeriram uma certa precaução ao interpretar os resultados desse estudo devido à falta de controle de diversas variáveis, como duração do tratamento, cooperação dos pacientes. e que há grande variação individual quanto às respostas dento-esqueléticas aos tratamentos.

No intuito de estudar a influência das diferentes direções de tração do aparelho extrabucal sobre os primeiros molares superiores, YOSHIDA; JOSTBRINKMANN; YAMADA ${ }^{134}$, em 1995, analisaram três estudantes, com idades entre 23 e 27 anos, e observaram que, com a utilização da tração occipital, as raízes dos primeiros molares superiores sofreram uma inclinação para distal, em decorrência da aplicação de força acima do centro de resistência. Um outro resultado, de grande importância, foi a vestibularização das coroas em conseqüência da aplicação de forças intrusivas, inerentes à tração occipital. Os autores alegaram ser a linha de ação da força uma importante consideração no controle dos efeitos de inclinação e que a posição do centro de resistência e outros fatores variam entre os indivíduos. Além destas afirmações, aconselharam os ortodontistas a verificarem e a ajustarem, regularmente, os 
aparelhos extrabucais durante todo o tratamento no afã de se constatar alguma característica indesejável que possa interferir nos movimentos dentários durante a mecanoterapia.

No propósito de avaliar os efeitos oclusais e cefalométricos de duas modalidades de tratamento da má oclusão de Classe II, bem como estabelecer o melhor período para a intervenção, GHAFARI; SHOFER; JACOBSSONHUNT; MARKOWITZ; LASTER ${ }^{55}$, em 1998, avaliaram sessenta e três pacientes, seguindo alguns pré-requisitos como: discrepância maxilomandibular de, no mínimo, 4,50 e idades esqueléticas variando de 5,7 a 13,7 anos. Dividiram-se os participantes em dois grupos: ambos os grupos compostos por jovens dos gêneros masculino e feminino, sendo que o primeiro apresentava pacientes com menos de 10 (feminino) e 10,5 anos (masculino), e o segundo grupo apresentava-se com gênero feminino, mais de 10 anos, e gênero masculino com mais de 10,5 anos. Os aparelhos de escolha foram o Regulador Funcional de Fränkel tipo II (16 horas por dia) e o aparelho Extrabucal de tração occipital (14 horas por dia), com a força passando, nesse último, pelo centro de resistência dos molares superiores. Os resultados mostraram que ambas as terapias foram efetivas no tratamento da má oclusão de Classe II, divisão 1, porém com respostas dentárias e esqueléticas diferenciadas. O alvo principal da mecânica extrabucal deu-se sobre a maxila (efeito ortopédico - significante redução da medida SNA levando è redução do ângulo ANB; efeito ortodôntico - distalização dos molares superiores e vestibularização dos incisivos superiores), enquanto que a mecânica ortopédica funcional ocorreu-se sobre ambos os maxilares (restrição do crescimento maxilar e posicionamento mais anterior da mandíbula), porém com respostas mais expressivas nos dentes anteriores (lingualização dos incisivos superiores e vestibularização dos inferiores contribuindo para a grande correção da sobressaliência). O efeito no comprimento mandibular, por sua vez, foi similar ao se comparar as modalidades terapêuticas. Os autores concluíram que ambas as épocas de instalação dos aparelhos foram eficientes, priorizando o final do período da dentadura mista por reduzir o tempo total de tratamento e incentivaram a realização de estudos mais específicos quanto à influência das 
características individuais na época do tratamento, bem como na resposta à mecânica empregada.

No intuito de estudar cefalometricamente os efeitos do uso do aparelho extrabucal tipo IHG, em pacientes portadores de má oclusão de Classe II, $1^{\mathrm{a}}$ divisão, KAMITSUJI ${ }^{73}$, em 1998, apresentou sua tese, em que avaliou 32 pacientes leucodermas, brasileros, de ambos os gêneros, com idade entre 10 anos e 11 meses e 15 anos e 10 meses. Após a análise dos resultados, pôde concluir entre outras observadas, que houve uma diminuição estatisticamente significante na profundidade maxilar; não foi observado dimorfismo sexual.

Revisando a literatura pertinente aos tratamentos ortodônticos com ancoragens extrabucais, HENRIQUES; FREITAS; HAYASAKI ${ }^{61}$ em 1999, reuniram os principais efeitos dentoesqueléticos com o aparelho Extrabucal de tração occipital. Resumiram-se os efeitos ortodônticos em: distalização dos molares superiores, para a obtenção da relação molar normal; controle de uma possível extrusão dos molares superiores ou, em alguns casos, a possibilidade de intruí-los; tendência de inclinação das raízes para a distal e baixo risco de impacção dos segundos molares superiores permanentes. Já os efeitos ortopédicos em: restrição do crescimento maxilar no sentido ântero-posterior, identificada por uma diminuição significativa do ângulo SNA; melhor relacionamento entre as bases ósseas, visto pelo ângulo ANB; o mento adquire, em geral, uma posição mais anterior quando comparado à tração cervical; a altura facial ântero-inferior, em alguns estudos, chegou a diminuir ao final do tratamento e, em outros, houve pequeno aumento, quando a tendência era aumentar acentuadamente, principalmente em pacientes com a AFAI aumentada ou em pacientes com tendência de crescimento vertical; e com o controle do desenvolvimento vertical da maxila, a tendência de rotação horária da mandíbula diminui, auxiliando na melhora do perfil facial do paciente e no relacionamento dos molares.

No ano seguinte (2000), outro trabalho foi publicado à respeito do tratamento da má oclusão de Classe $\mathrm{II}, 1^{\mathrm{a}}$ divisão em pacientes com padrão de crescimento facial vertical, utilizando a ancoragem extrabucal, por 
HENRIQUES et. al. ${ }^{62}$. Os autores apresentaram dois casos clínicos, um utilizando a aparelho extrabucal com tração cervical, e outro utilizando o mesmo aparelho com tração occipital, e concluíram que o tratamento desta má oclusão em pacientes com padrão de crescimento facial vertical com os dois tipos de tração, mostrou-se eficiente. Houve melhora na relação maxilomandibular e diminuição do ângulo ANB, devido principalmente à retrusão da maxila (SNA) e não ocorreu alteração no padrão facial vertical, no caso tratado com o aparelho extrabucal de tração occipital.

Ainda no mesmo ano (2000), outro trabalho também enfatizando a utilização da ancoragem extrabucal occipital (IHG) na correção da má oclusão de Classe II, $1^{\text {a }}$ divisão, e com um acompanhamento de 12 anos, foi apresentado por HENRIQUES, et. al. ${ }^{59}$. Os autores associaram ao aparelho extrabucal o aparelho fixo e a extração de quatro pré-molares. Demonstraram um caso clínico tratado da maneira especificada, e concluíram que o aparelho extrabucal com tração occipital mostrou-se um recurso eficiente durante 0 tratamento da má oclusão de Classe II, $1^{\text {a }}$ divisão, tendo sido eficaz na restrição do desenvolvimento ântero-posterior da maxila e na manutenção da ancoragem dos molares superiores, assim como no controle do crescimento vertical da face. Os resultados obtidos na correção da má oclusão mantiveramse estáveis após 12 anos do término do tratamento.

Mais atualmente, no ano de 2001, BILLET; PAUW; DERMAUT ${ }^{24}$ estudaram os efeitos no complexo nasomaxilar por meio de holograma, em um crânio humano macerado, pela a aplicação de forças em diferentes direções, simulando as trações baixa e média-alta. As respostas adquiridas mostraram que a região do centro de resistência da maxila situou-se abaixo do processo zigomático do complexo maxilar, pois quando o vetor de força era aplicado por esta região, o movimento de translação puro da maxila era induzido. Conseqüentemente, forças aplicadas acima desse centro e/ou abaixo, rotações no sentido anti-horário da maxila e no sentido horário eram visualizadas respectivamente. 
Atualmente, em 2004, NAHÁS ${ }^{95}$, apresentou sua tese de doutorado, onde estudou cefalometricamente as alterações dentoesqueléticas da má oclusão de Classe II, $1^{\text {a }}$ divisão, tratada com o aparelho de Herbst e com o aparelho extrabucal de tração occipital (IHG). Realizou a divisão da amostra em quatro grupos, sendo dois experimentais e dois controles, com todos os pacientes apresentando a má oclusão de Classe II, $1^{\text {a }}$ divisão. Após todos os estudos, concluiu que o tratamento com o aparelho extrabucal de tração occipital alterou a tendência de deslocamento anterior da maxila de modo significante; o crescimento mandibular não foi influenciado pelo tratamento; houve uma significativa melhora na relação maxilomandibular e na convexidade facial, principalmente em decorrência do efeito inibitório da terapia sobre o osso basal superior no sentido sagital; o padrão de crescimento craniofacial não foi influenciado pelo tratamento; o tratamento com o aparelho extrabucal restringiu o desenvolvimento dos molares superiores nos sentidos vertical e sagital de modo significante; a relação molar de Classe II foi corrigida, com conseqüente redução da projeção do lábio superior.

\subsubsection{CONCLUSÕES DOS TRABALHOS ANALISADOS PERTINENTES AO APARELHO EXTRABUCAL DE TRAÇÃO OCCIPITAL (IHG):}

Dentre as trações que podem ser exercidas sob os aparelhos extrabucais, há a tração occipital (IHG), a qual mostra-se muito estudada e discutida, principalmente por apresentar determinados resultados no tratamento da má oclusão de Classe II, $1^{\text {a }}$ divisão, que diferem dos encontrados em estudos pertinentes aos outros tipos de tração.

Observa-se que com a utilização da tração occipital obtém-se uma alteração na tendência de deslocamento anterior da maxila de modo significante; o crescimento mandibular não é influenciado pelo tratamento; há uma significativa melhora na relação maxilomandibular e na convexidade facial, principalmente em decorrência do efeito inibitório da terapia sobre o osso basal superior no sentido sagital; o padrão de crescimento craniofacial não é influenciado pelo tratamento; o tratamento com o aparelho extrabucal restringe o desenvolvimento dos molares superiores nos sentidos vertical e sagital de 
modo significante; a relação molar de Classe II é corrigida, com conseqüente redução da projeção do lábio superior também ${ }^{95}$. 


\section{Proposição}




\section{PROPOSIÇÃO}

O presente estudo têm como propósito principal avaliar cefalometricamente as alterações decorrentes do uso de dois tipos de aparelhos extrabucais em jovens que apresentam a má oclusão de Classe II, $1^{\mathrm{a}}$ divisão e pertencentes à mesma faixa de idade.

Os principais tópicos a serem avaliados neste estudo foram dispostos da seguinte maneira:

3.1 Alterações esqueléticas:

3.1.1 Componente maxilar;

3.1.2 Componente mandibular;

3.1.3 Relação maxilomandibular:

3.1.4 Relação vertical.

3.2 Componente dentoalveolar.

3.3 Componente tegumentar. 


\section{Material e Métodos}




\section{MATERIAL E MÉTODOS}

\subsection{Material}

\subsubsection{Obtenção da amostra}

A amostra constituiu-se de 150 telerradiografias em norma lateral, de 75 jovens brasileiros de ambos os gêneros provenientes do acervo da Disciplina de Ortodontia da Faculdade de Odontologia de Bauru, Universidade de São Paulo. O critério para seleção da amostra baseou-se nas seguintes características dos pacientes:

1 - os jovens apresentavam inicialmente má oclusão de Classe II, $1^{\text {a }}$ divisão de Angle;

2 - exclusão de jovens Classe II, $1^{a}$ divisão, subdivisão;

3 - leucodermas, descendentes de portugueses, italianos e espanhóis;

4 - ausência de agenesias ou perdas de dentes permanentes;

5 - os jovens apresentavam padrão de crescimento vertical.

A amostra foi dividida em três grupos, sendo dois grupos experimentais e um grupo controle, no intuito de comparar os efeitos dos tratamentos, com as alterações advindas do crescimento, na má oclusão de Classe II, $1^{\mathrm{a}}$ divisão, de Angle:

Grupo 1: Composto por pacientes submetidos ao tratamento utilizando o aparelho extrabucal conjugado (Splint Maxilar Modificado), apresentando 13 jovens do gênero masculino e 12 do feminino, com idade média inicial de 9,71 anos e acompanhados por um período médio de 1,41 anos. Estes pacientes foram tratados na clínica de Pós-graduação da Faculdade de Odontologia de Bauru, FOB-USP (figuras A e B).

Grupo 2: Composto por pacientes tratados com o aparelho extrabucal de tração média alta (IHG - Interlandi Head Gear), constituindo-se de 13 jovens do 
gênero masculino e 12 do feminino, com idade média inicial de 10,51 anos acompanhados por um período médio de 1,32 anos. Os pacientes foram tratados nos cursos de Pós-graduação da Faculdade de Odontologia de Bauru, FOB-USP (figuras C e D).

Grupo 3 (controle): Constituído de 25 jovens, sendo 13 do gênero masculino e 12 do feminino que apresentavam má oclusão de Classe II, $1^{\text {a }}$ divisão de Angle, não submetidos ao tratamento ortodôntico, com idade média inicial de 10,06 anos, acompanhados por um período médio de 1,35 anos. Selecionou-se esta amostra a partir de um grupo de jovens que foi anualmente radiografado e controlado pela Disciplina de Ortodontia da FOB-USP com o fim de obter uma amostra longitudinal de jovens, desde a dentadura mista até a permanente. 
4.1.2 Descrição dos aparelhos utilizados nos grupos experimentais

\subsubsection{Aparelho Extrabucal Conjugado}

O AEB conjugado é caracterizado como sendo um aparelho ortopédico, composto por uma placa de acrílico superior com levantamento oclusal e com parafuso expansor, arco facial e casquete com tração alta. Para a retenção da placa, são construídos grampos de Adams nos molares e um arco vestibular para a verticalização dos incisivos, se necessário, ou para prevenir a sua vestibularização.

O arco facial é incluído no acrílico passando por distal dos primeiros molares decíduos ou entre os pré-molares com inclinação de 45 graus à cima do plano oclusal, com força direcionada ao centro de resistência da maxila, gerando força de compressão perpendicularmente às suturas primárias maxilares (Frontomaxilar, Zigomaticomaxilar e Pterigopalatina). As extremidades do arco externo são dobradas na altura dos primeiros molares superiores ou ao nível do canto externo do olho, onde são inseridos os elásticos para promoverem uma força com ponto de aplicação mais próximo ao centro de resistência da maxila. Neste gancho, são utilizados elásticos de 1/2 polegada de diâmetro acoplados ao casquete com tração alta, permitindo uma restrição tanto do crescimento da maxila quanto da extrusão dos molares superiores, melhorando o relacionamento maxilomandibular. O acrílico que recobre a face oclusal dos dentes posteriores deve ser delgado, para não promover a translação condilar ou aumento da altura facial do paciente, geralmente vertical.

Utilização clínica do aparelho:

Nesta amostra estudada, o tempo de utilização do aparelho foi de 14 a 16 horas por dia, sob a aplicação de uma força de 350 a 500g, com os elásticos de tração de $1 / 2$ polegada, trocados pelos pacientes de três em três dias. A ativação do parafuso expansor foi realizada mensalmente, realizando 1/4 de volta a cada ativação, para melhor ajuste transversal da maxila com a 
mandíbula, quando necessário. Após o tratamento ativo, a contenção foi realizada com o mesmo aparelho, porém utilizado somente no período noturno, por um tempo de pelo menos a metade daquele estabelecido para a correção da Classe II, sendo eliminado gradualmente.

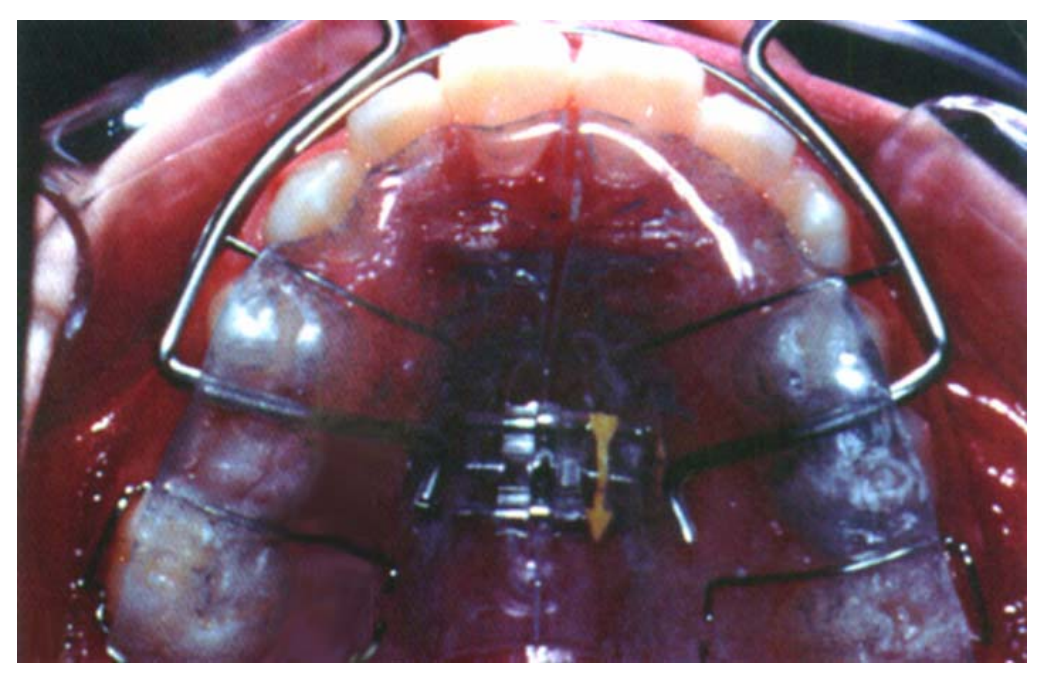

Figura A: Vista oclusal superior - aparelho AEB conjugado.

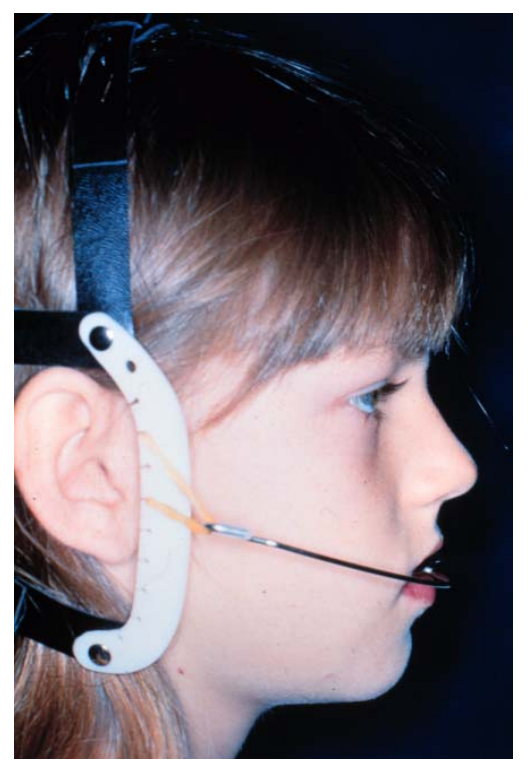

Figura B: Foto extrabucal de perfil - paciente com o aparelho AEB conjugado. 


\subsubsection{Aparelho Extrabucal de tração occipital (IHG):}

Dentre as diferentes modalidades de ancoragem extrabucal ${ }^{62,79,105,114}$, classificadas quanto à direção de tração em alta ou parietal, média ou occipital e baixa ou cervical, este estudo estabeleceu-se sob pacientes tratados apenas com aparelho extrabucal de tração média ou occipital, difundido como IHG, que abrevia a denominação "Interlandi Headgear"49. Esse sistema de ancoragem extrabucal, idealizado por Interlandi ${ }^{16}$, constitui-se de um casquete compreendido por 3 tiras de apoio, que se adaptam nas áreas cervical, occipital e parietal, juntam-se à frente do pavilhão auditivo por meio de uma lâmina plástica em forma de $\mathrm{C}$, com ranhuras na borda interna permitindo direcionar os elásticos, os quais tracionam o arco externo e este, por sua vez, o interno, que se encontra ajustado nos tubos dos molares.

Instalação:

Nos primeiros molares superiores são instaladas as bandas com os seus respectivos tubos voltados para a cervical, para a adaptação do arco interno. Em seguida, ajusta-se o arco facial, levando em consideração as seguintes características: localizado passivamente entre os lábios; centralizado com o linha média do paciente; $6 \mathrm{~mm}$ afastado dos incisivos centrais superiores; $3 \mathrm{~mm}$ afastado dos tubos dos molares; arco interno paralelo ao plano oclusal; e o arco externo, aproximadamente $1 \mathrm{~mm}$ maior que o arco interno. Finalmente, adaptava-se o casquete na cabeça do paciente e os elásticos (tamanho 1/2", com uma magnitude média de força de 350 a 500 gramas por lado). A força do aparelho, liberada pelos elásticos, era ajustada tornando possível que sua linha de ação passasse aproximadamente pelo centro de resistência do primeiro molar superior (área de trifurcação das raízes do molar $^{123}$ ) e com uma direção para superior e posterior.

Protocolo de tratamento:

Os pacientes foram orientados à utilizarem os aparelhos extrabucais pelo maior número de horas contínuas por dia, com exceção durante às refeições, escovações dentárias e na prática de esportes. Preconizou-se a troca de elásticos a cada três dias, pelo próprio paciente. 
As manutenções foram realizadas mensalmente com o objetivo de conferir as características do arco facial, mobilidade dos primeiros molares superiores, alterações oclusais alcançadas e averiguar se realmente todos os pacientes estavam utilizando o aparelho conforme recomendado. Era essencial manter constante a ativação e a direção da força dos elásticos durante todo o tratamento. Após o tratamento ativo, a contenção foi realizada com o mesmo aparelho, porém utilizado somente no período noturno, por um tempo de pelo menos a metade daquele estabelecido para a correção da Classe II, sendo eliminado gradualmente.

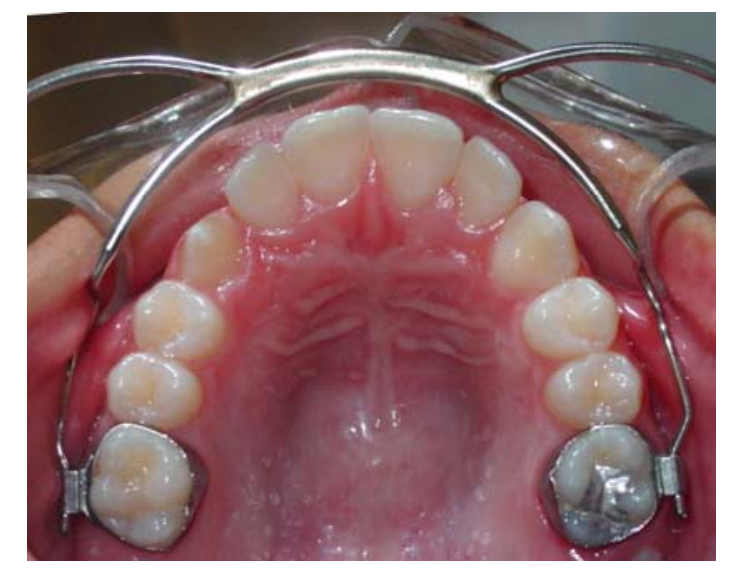

Figura C: Vista oclusal superior - aparelho IHG.

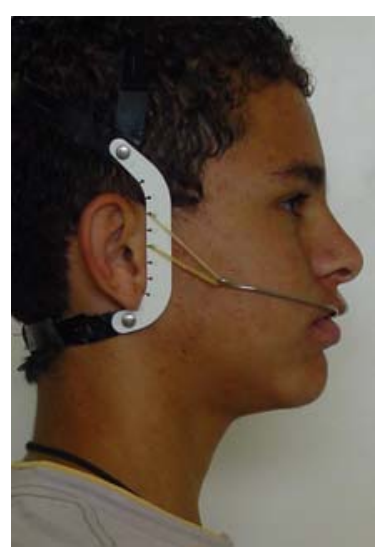

Figura D: Foto extrabucal lateral - paciente com o aparelho IHG.

\subsection{Métodos}

\subsubsection{Radiografias cefalométricas}


Utilizou-se duas telerradiografias em norma lateral de cada paciente. Estas radiografias foram obtidas em diferentes aparelhos, porém em todas as tomadas radiográficas respeitaram-se os critérios convencionais de padronização para as técnicas e processamentos dos filmes radiográficos, recomendados pela Disciplina de Radiologia da Faculdade de Odontologia de Bauru, da Universidade de São Paulo. Os fatores de magnificação foram determinados em $6 \%, 7,14 \%, 9,5 \%$ e 9,8\% para os grupos experimentais, e $6 \%$ para as radiografias do grupo controle.

\subsubsection{Elaboração do cefalograma}

Para a realização do cefalograma adaptou-se em cada película radiográfica uma folha de papel de acetato transparente "ultraphan", da marca UNITEK/3M de tamanho $17,5 \mathrm{~cm}$ de largura por $17,5 \mathrm{~cm}$ de comprimento e espessura de $0,07 \mathrm{~mm}$. Os cefalogramas foram traçados manualmente sobre 0 negatoscópio, pelo pesquisador e conferido pelo orientador da investigação, em uma sala obscurecida, emoldurado com cartolina preta, expondo-se as áreas correspondentes ao desenho anatômico, que foi realizado com uma lapiseira com grafite de $0,5 \mathrm{~mm}$. Ressalta-se que estruturas pares determinouse a média, possibilitando maior precisão na localização dos pontos cefalométricos (BAUMRIND; FRANTZ ${ }^{18}$ ). Quanto a localização dos dentes (molares e incisivos) respeitou-se os mais distalmente posicionados (molares) e mais anteriormente posicionados para os incisivos. Por meio de uma mesa digitalizadora Houston Instruments DT-11*, acoplada a um microcomputador 586 Pentium, transferiu-se a localização dos pontos dos cefalogramas para 0 programa de cefalometria Dentofacial Planner 7.0** onde foram processadas as mensurações envolvendo os planos e as linhas. Neste programa obteve-se a correção da magnificação da imagem radiográfica, uma vez que as radiografias foram obtidas em diferentes aparelhos.

*Houston Instruments - Austin, Texas, USA.

**Dentofacial Planner Software Inc., Toronto, Ontario, Canada.
4.2.2.1
Delimitação das
estruturas
dentoesqueléticas e do perfil tegumentar (figura 1) 
Perfil do osso frontal e dos ossos nasais: parte mais externa do osso frontal e o limite anterior dos ossos nasais unidos entre si pela sutura frontonasal.

Contorno do perfil tegumentar: partindo da metade inferior da fronte, até completar o contorno do mento, interrompido na altura dos lábios quando entreabertos.

Órbita: contorno póstero-inferior das cavidades orbitárias.

Sela túrcica: contorno anterior, inferior e posterior da sela, estendendo-se anterior e, posteriormente, abrangendo os processos clinóides anterior e posterior e o contorno do clívus do osso esfenóide.

Fissura pterigomaxilar: limite posterior da tuberosidade maxilar e anterior do processo pterigóide do osso esfenóide.

Meato acústico externo: contorno da imagem radiolúcida do meato acústico externo.

Maxila: contorno da concavidade anterior, desde a espinha nasal anterior até próximo à região cervical das coroas dos incisivos, estendendo-se posteriormente da espinha nasal anterior até a posterior, por sobre a cortical do assoalho das fossas nasais, completando-se o desenho com uma linha correspondente ao limite inferior da região anterior do palato duro.

Mandíbula: contorno da cortical externa da sínfise e média das bordas do corpo mandibular, dos ramos ascendentes e dos côndilos.

Incisivos centrais permanentes superiores e inferiores: contorno das coroas e raízes dentárias dos incisivos superiores e inferiores mais vestibularizados.

Primeiros molares permanentes superiores e inferiores: contorno das coroas e raízes dentárias. 
DESENHO ANATÔMICO

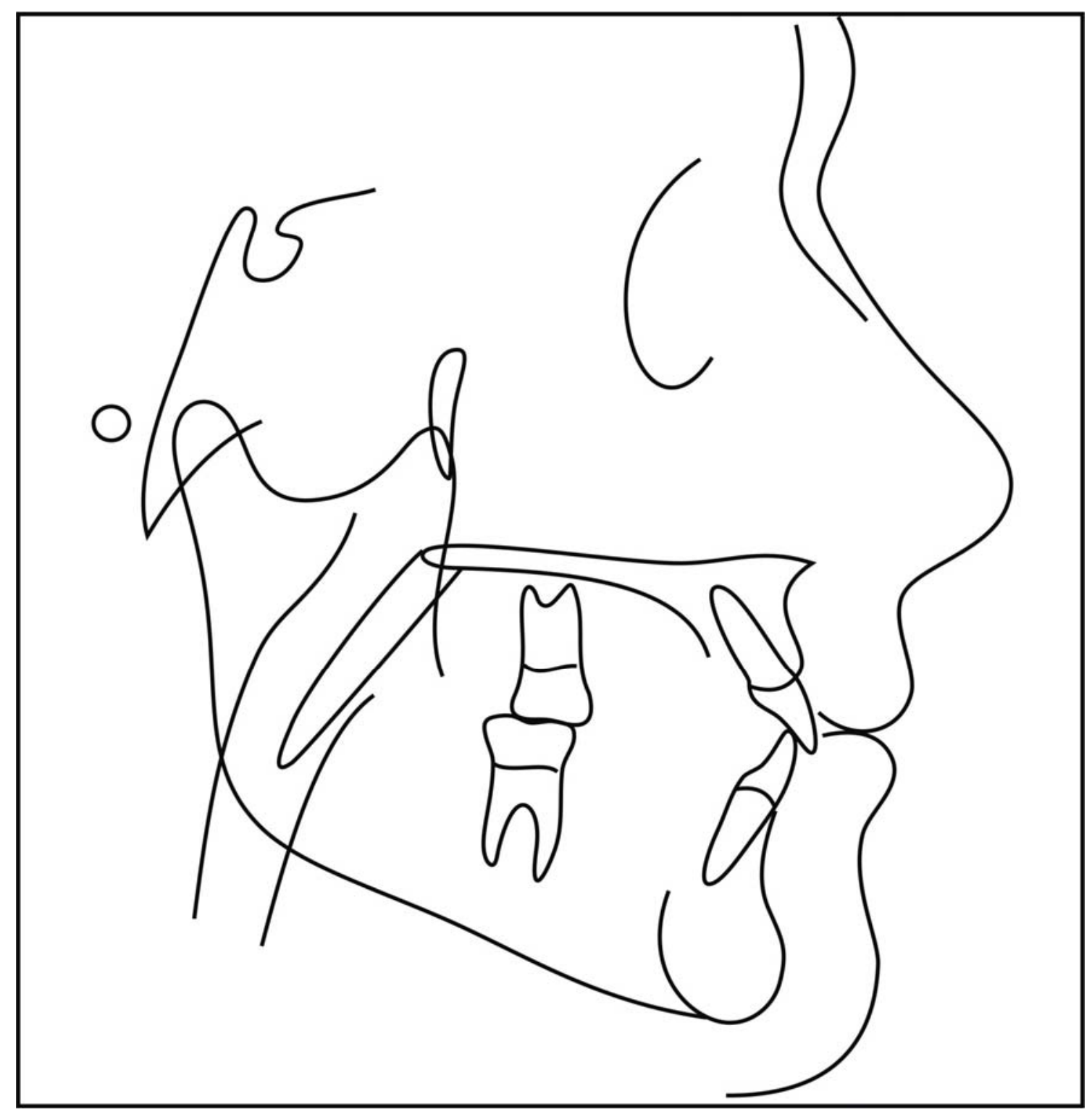

Figura 1 - Traçado das estruturas dentoesqueléticas e do perfil tegumentar.

4.2.2.2 Demarcação dos pontos cefalométricos de referência (figura 2) 
Serão descritos apenas os pontos necessários para a análise específica preconizada, baseada em radiografias cefalométricas em norma lateral ${ }^{52}$.

I - Násio (N): União da sutura internasal com a sutura frontonasal (ponto mais anterior da sutura frontonasal).

II - Sela (S): Localizado no centro da sela turca.

III - Ponto A: Ponto mais profundo no contorno da projeção alveolar entre a espinha nasal anterior e a crista alveolar superior.

IV - Ponto B: Ponto mais profundo da concavidade anterior da mandíbula.

V - Espinha Nasal Anterior (ENA): Ponto mais anterior na imagem radiográfica da espinha nasal anterior.

VI - Espinha Nasal Posterior (ENP): Ponto mais posterior da lâmina horizontal do osso palatino.

VII - Gônio (Go): Ponto mais inferior e posterior do ângulo da mandíbula e deve ser o ponto que divide a borda distal do ramo mandibular e a borda inferior do corpo mandibular.

VIII - Pório (Po): Ponto mais superior do meato auditivo externo.

IX - Orbitário (Or): Ponto mais inferior do rebordo orbital inferior.

X - Mentoniano (Me): Ponto mais inferior no contorno da sínfise.

XI - Condílio (Co): Ponto mais póstero-superior dos côndilos mandibulares.

XII - Gnátio (Gn): Ponto mais anterior e inferior do contorno da sínfise mentoniana. 
XIII - Articular (Ar): Ponto virtual de intersecção da imagem do contorno posterior do côndilo mandibular com a imagem do contorno externo do terço médio da base do crânio, correspondendo ao osso occipital.

XIV - Pronasal (Pm): Ponto mais anterior e inferior do nariz.

XV - Columela (ou derivado do pronasal) (Prn'): Ponto mais proeminente, na margem inferior da columela do nariz, localizado entre o pronasal e o subnasal.

XVI - Subnasal (Sn): Ponto de confluência entre a margem inferior da columela do nariz e o lábio superior.

XVII - Pog': Ponto mais anterior e superior do tecido mole do mento.

XVIII - Li: Ponto mais anterior do contorno do lábio inferior.

XIX - Ls: Ponto mais proeminente do lábio superior.

XX - Pt: Ponto localizado na extremidade mais superior e posterior da fossa pterigopalatina.

XXI - Borda do incisivo superior (BIS): Ponto mais inferior da borda incisal do incisivo central superior.

XXII - Ápice do incisivo superior (AIS): Ponto mais superior da raiz do incisivo central superior.

XXIII - Borda do incisivo inferior (BII): Ponto mais superior da borda incisal do incisivo central superior.

XXIV - Ápice do incisivo inferior (AII): Ponto mais inferior da raiz do incisivo central inferior. 
XXV - Cúspide mésiovestibular do primeiro molar superior (CMPMS): Ponto mais inferior da cúspide mésio-vestibular do primeiro molar superior.

XXVI - Distal do primeiro molar superior (DPMS): Ponto localizado na distal da coroa do primeiro molar superior.

XXVII - Ápice do primeiro molar superior (APMS): Ponto localizado no ápice da raiz mésiovestibular do primeiro molar superior.

XXVIII - Cúspide mésiovestibular do primeiro molar inferior (CMPMI): Ponto mais superior da cúspide mésio-vestibular do primeiro molar inferior. 


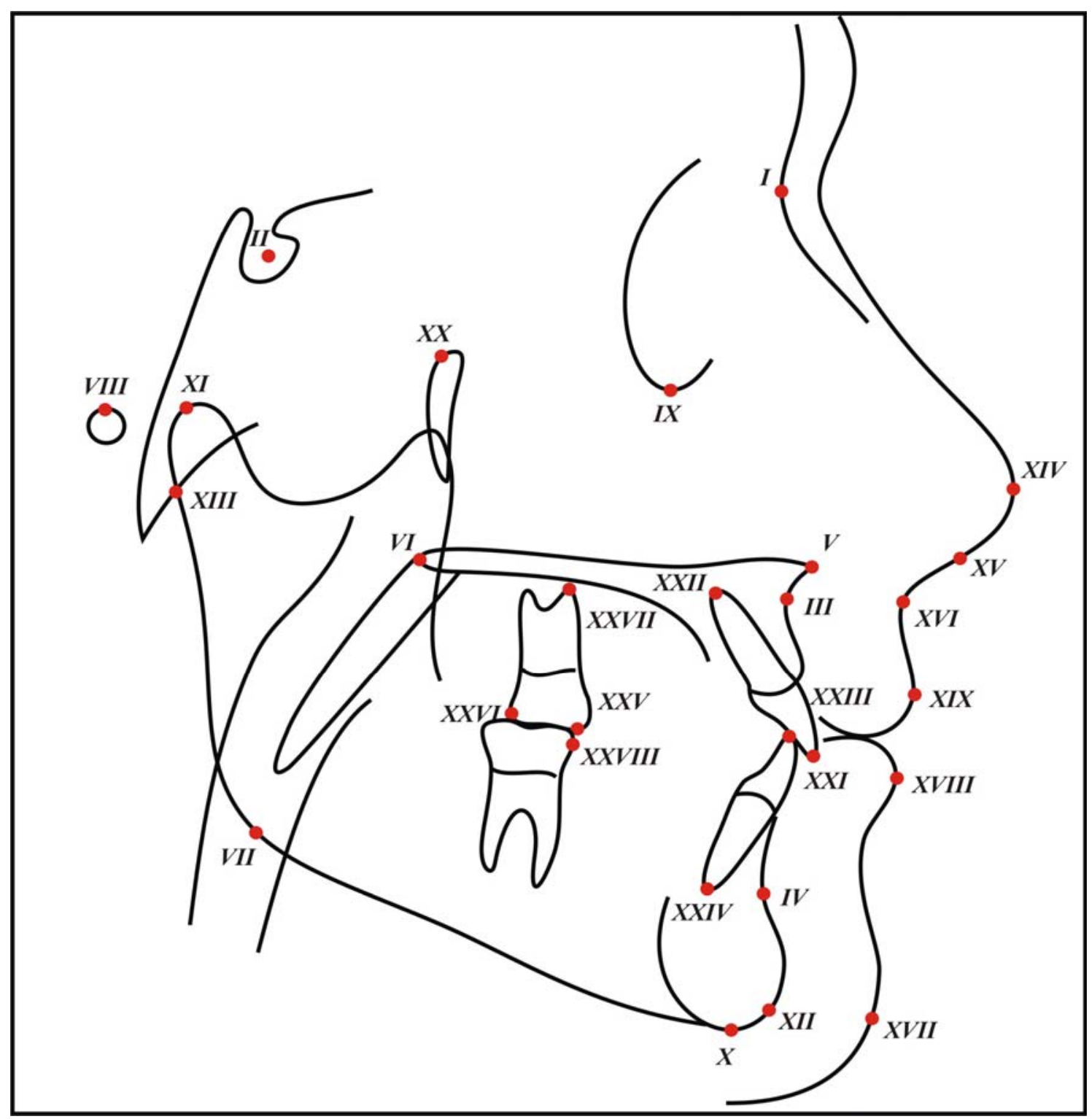

FIGURA 2: Pontos cefalométricos utilizados

\subsubsection{Planos e Linhas de referência (figura 3):}

4.2.2.3.1 Horizontais

1 - Linha SN: linha que passa pelos pontos S e N. 
2 - Plano de Frankfurt: plano formado pela união dos pontos Po e Or.

3 - Plano palatino: plano formado pela união dos pontos ENA (espinha nasal anterior) e ENP (espinha nasal posterior).

4 - Plano mandibular: plano formado pela união dos pontos Go e Me.

5 - Plano oclusal: plano que tangencia a cúspide distal do primeiro molar inferior e a incisal do incisivo inferior (BII).

6 - Plano horizontal de Frankfurt modificado (FH): constituído por uma linha que forma com a linha SN um ângulo de 7 graus para baixo, passando pelo ponto S.

\subsection{Verticais}

7 - Linha NA: linha que passa pelos pontos $\mathrm{N}$ e $\mathrm{A}$.

8 - Linha NB: linha que passa pelos pontos N e B.

9 - Longo eixo do incisivo superior: linha que passa pelos pontos BIS e AIS.

10 - Linha ENA-Me (AFAI): linha que passa pelos pontos ENA e Me.

11 - Linha Pt-FHp: perpendicular ao plano de Frankfurt modificado (FH), partindo do ponto $\mathrm{Pt}$.

12 - Linha Estética (E): linha que passa pelos pontos Pog' e Prn.

13 - Linha Ar-Go: linha que passa pelos pontos Ar e Go. 


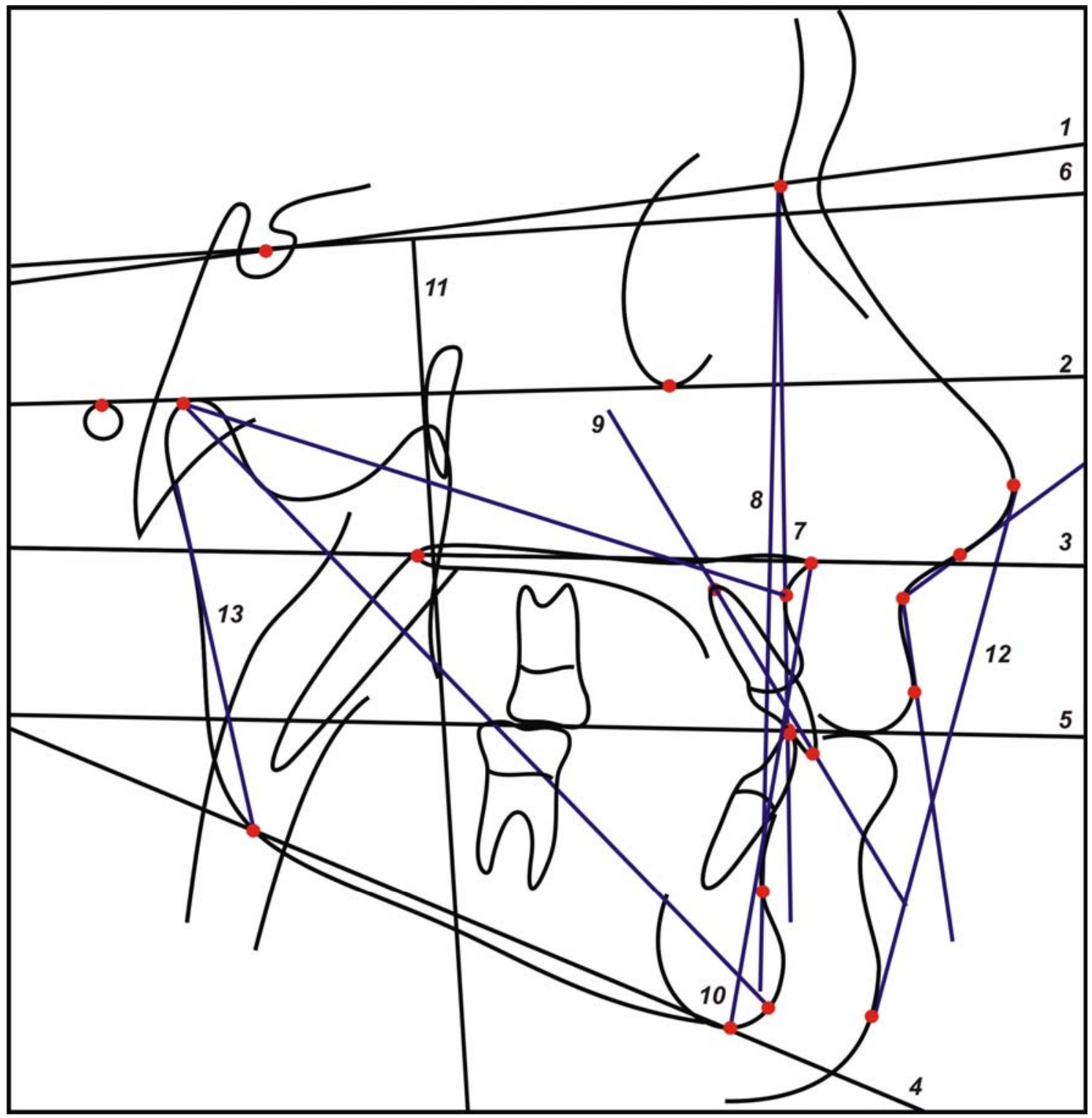

FIGURA 3: Planos e linhas de referência

4.2.2.4 Grandezas angulares e lineares:

4.2.2.4.1 Grandezas angulares: 
I - SNA: ângulo formado pelas linhas SN e NA.

II - SNB: ângulo formado pelas linhas SN e NB.

III - ANB: diferença entre os ângulos SNA e SNB.

IV - ANL (ângulo nasolabial): ângulo formado por duas semi-retas que passam pelos pontos derivados do pronasal (Prn') e lábio superior (Ls), respectivamente, apresentando como ponto comum o subnasal (Sn).

V - SN.PP: ângulo formado entre a linha SN e o plano palatino (PP).

VI - SN.GoMe: ângulo formado entre a linha SN e o plano mandibular (GoMe).

VII - PP.GoMe: ângulo formado entre o plano palatino (PP) e o plano mandibular (GoMe).

VIII - FMA: ângulo formado entre o plano de Frankfurt (Po-Or) e o plano mandibular (GoMe).

IX - 1.NA: ângulo formado pelo longo eixo do incisivo superior com a linha NA.

X - Ar.GoMe: ângulo formado pela linha Ar-Go e o plano mandibular (GoMe). 


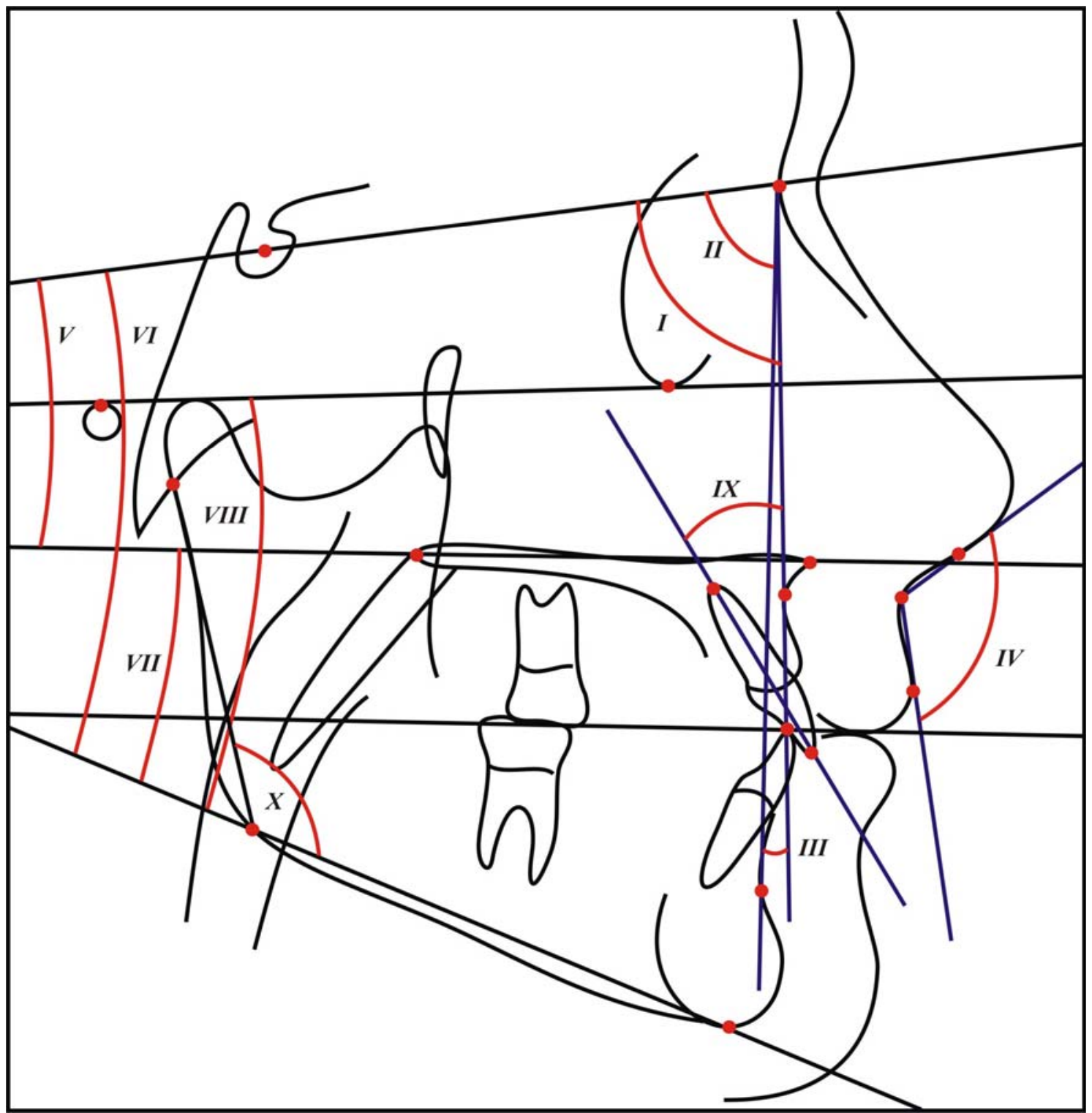

FIGURA 4: Grandezas angulares

4.2.2.4.2 Grandezas lineares: 
I - 6-FHp: distância entre a distal do primeiro molar superior permanente à linha Pt-FHp.

II - Ápice 6-FHp: distância do ápice da raiz mesial do primeiro molar superior permanente à linha Pt-FHp.

III - ㅁ-PP: distância da cúspide mésio-vestibular do primeiro molar permanente ao plano palatino (PP).

IV - A-Pt-FHp: distância do ponto A à linha Pt-FHp.

V -1̄-Me: distância da ponta de cúspide do incisivo inferior (BII) ao ponto Me.

VI - 1-PP: distância perpendicular da ponta de cúspide do incisivo superior (BIS) ao plano palatino (PP).

VII - Co-A: distância do ponto Co ao ponto A.

VIII - Co-Gn: distância do ponto Co ao ponto Gn.

IX - AFAI (ENA-Me): distância do ponto ENA ao ponto Me.

X - $\overline{6}$-GoMe: distância da cúspide mesial do primeiro molar inferior perpendicular ao plano mandibular (Go-Me).

XI - Ls-E: distância do ponto Ls à linha $E$.

XII - Li-E: distância do ponto Li à linha E. 


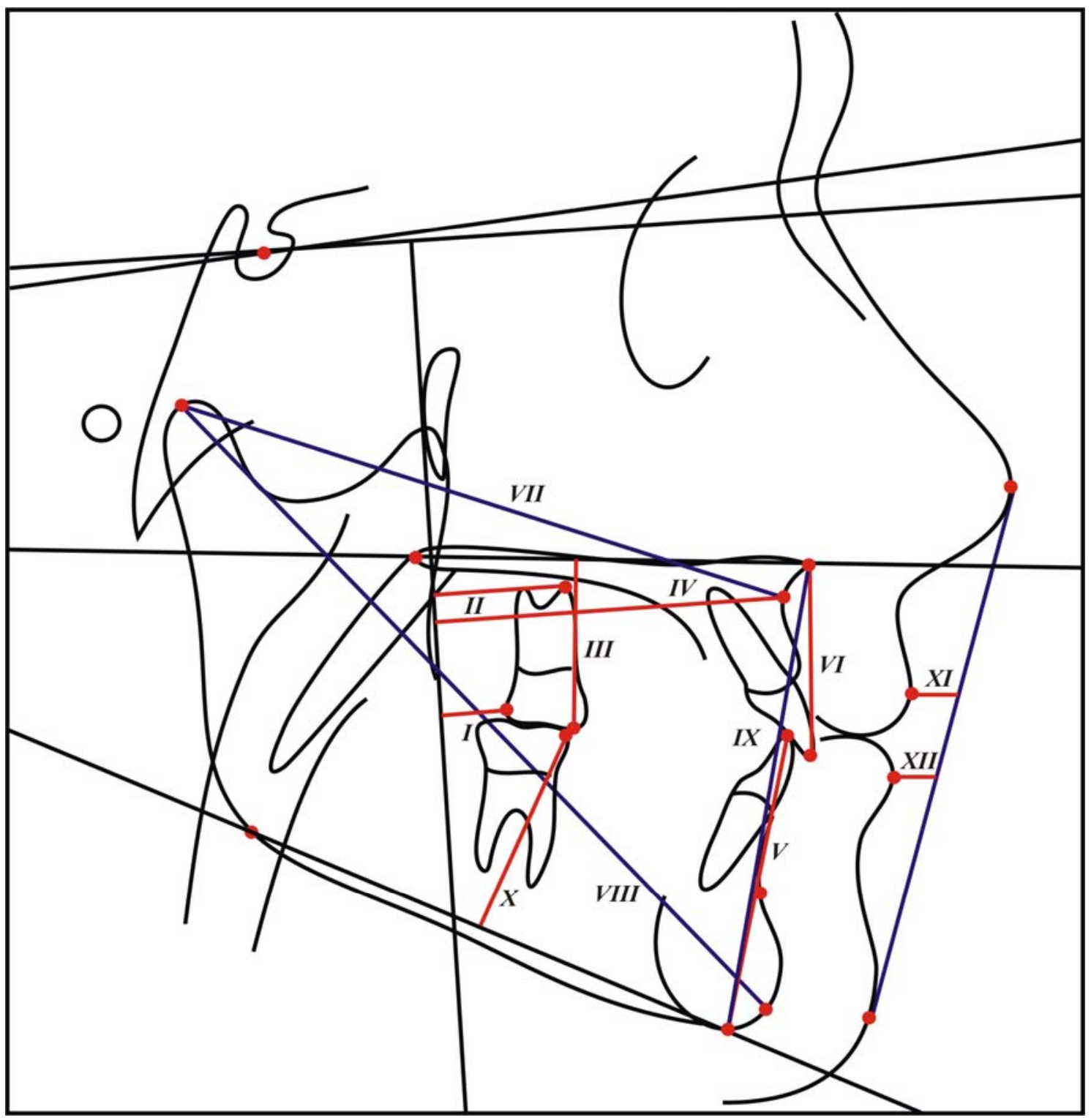

FIGURA 5: Grandezas lineares 


\subsection{Análise Estatística:}

\subsection{1: $\quad$ Erro do método:}

Com o intuito de determinar a confiabilidade dos resultados da pesquisa, foram selecionadas aleatoriamente 20 telerradiografias provenientes dos 3 grupos distintos estudados. Estas telerradiografias foram traçadas $\mathrm{e}$ digitalizadas novamente por um único operador após um período de 1 mês, do traçado inicial. Determinou-se então a diferença entre a primeira e a segunda mensuração de cada telerradiografia, e aplicou-se a fórmula de Dahlberg para visualização do erro casual, segundo HOUSTON ${ }^{69}$.

$$
\mathrm{E}=\sqrt{\sum d^{2} / 2 n}
$$

O erro sistemático foi detectado comparando as medições por meio do teste "t" pareado, utilizando o programa estatístico: Statística 6.0*.

\subsection{2: Comparação entre os grupos:}

Realizou-se primeiramente uma análise intergrupos das medidas iniciais das grandezas cefalométricas de cada grupo, utilizando a análise de Variância (ANOVA), com o objetivo de verificar o grau de similaridade entre os grupos.

Posteriormente, as alterações reais foram determinadas pelas diferenças entre as mensurações nas fases pré e pós-tratamento. Os dados obtidos nas medidas cefalométricas para os três grupos foram computados pela análise de variância (ANOVA) para a verificação da hipótese nula de que os efeitos do crescimento no grupo 3, ou do tratamento nos grupos 1 e 2 são iguais. Quando verificadas diferenças estatísticas entre os grupos, os valores das alterações das médias foram submetidos ao teste estatístico de Tukey, com a finalidade de identificar quais foram responsáveis pela rejeição da hipótese nula, de igualdade entre os grupos. Em todas as análises empregadas foram considerados estatisticamente significantes os resultados com valor de $p<0,05$ e $p<0,01$.

*Statistical Software for Windows Version 6.0 


\section{Resultados}




\section{RESULTADOS}

Para a verificação das alterações cefalométricas ocorridas nos três grupos, foram calculadas as diferenças entre as medidas inicial e final (subtraindo do valor final, o valor inicial).

Primeiramente foi realizado o erro do método cefalométrico, por meio do teste "t" e da fórmula de Dahlberg. Após foi realizado a comparação intergrupos dos resultados pela análise de variância (ANOVA) (tabela 1) que foi complementada pelo teste de Tukey (tabela 2). Os dados foram dispostos em tabelas, respeitando a análise estatística empregada.

Os valores individuais de cada paciente encontram-se nos apêndices 1,2 e 3 .

TABELA 1 - Análise de Variância (ANOVA) entre as médias das idades iniciais e finais dos jovens nos 3 grupos e do tempo médio de tratamento.

\begin{tabular}{r|c|c|c|c|c}
\hline & \multicolumn{2}{|c|}{$\begin{array}{c}\text { Médias das idades iniciais, } \\
\text { finais e tempo de tratamento } \\
\text { (em anos) }\end{array}$} & \multicolumn{2}{c}{ Significância } \\
\hline & Grupo 1 & Grupo 2 & Grupo 3 & P & \\
\hline & & & & & \\
\hline Idade inicial & 9,71 & 10,51 & 10,06 & 0,036 & SIG* \\
\hline & & & & & \\
\hline Idade final & 11,12 & 11,83 & 11,41 & 0,068 & N/SIG \\
\hline $\begin{array}{c}\text { Tempo de } \\
\text { tratamento }\end{array}$ & 1,41 & 1,32 & 1,35 & 0,856 & N/SIG \\
\hline
\end{tabular}

N/SIG: não significante

SIG*: significante $(p<0,05)$ 
TABELA 2 - Teste de Tukey para a média das idades iniciais.

\begin{tabular}{|c|c|c|c|}
\hline \multicolumn{2}{|c|}{$\begin{array}{l}\text { Médias das medidas iniciais } \\
\text { (em anos) }\end{array}$} & \multirow{2}{*}{$\begin{array}{r}\text { Tuckey } \\
\text { P } \\
\end{array}$} & \multirow[t]{2}{*}{ Significância } \\
\hline Grupo 1 & Grupo 2 & & \\
\hline 9,71 & 10,51 & 0,028 & SIG* \\
\hline \multicolumn{2}{|c|}{ Médias das medidas iniciais } & \multicolumn{2}{|l|}{ Tuckey } \\
\hline Grupo 2 & Grupo 3 & $\mathbf{P}$ & \\
\hline 10,51 & 10,06 & 0,308 & $\mathrm{~N} / \mathrm{SIG}$ \\
\hline \multicolumn{2}{|c|}{ Médias das medidas iniciais } & \multicolumn{2}{|l|}{ Tuckey } \\
\hline Grupo 1 & Grupo 3 & $\mathbf{P}$ & \\
\hline 9,71 & 10,06 & 0,481 & $\mathrm{~N} / \mathrm{SIG}$ \\
\hline
\end{tabular}

N/SIG: não significante

SIG*: significante $(p<0,05)$ 


\subsection{ERRO DO MÉTODO (tabela 3)}

Determinou-se a diferença entre a primeira e a segunda mensuração de cada telerradiografia, e aplicou-se a fórmula de Dahlberg para determinação do erro casual, e o teste "t" de Student pareado para a obtenção do erro sistemático.

A tabela 3 apresenta os resultados do erro do método cefalométrico.

Os valores das grandezas cefalométricas avaliadas encontram-se nos apêndices. 
TABELA 3: Cálculo do erro do método intra-examinador. Primeira medida e desvio padão, segunda medida e desvio padão, erro casual (Dahlberg) e erro sistemático (teste t pareado).

\begin{tabular}{|c|c|c|c|c|c|c|c|}
\hline Variáveis & $1^{\mathrm{a}}$ Medida & d.p. & $2^{\mathrm{a}}$ Medida & d.p. & Dahlberg & $\mathbf{p}$ & Signific. \\
\hline \multicolumn{8}{|c|}{ Componentes maxilares } \\
\hline SNA & 84,11 & 3,89 & 84,90 & 3,79 & 1,02 & 0,010 & SIG** \\
\hline FHP-A & 49,75 & 2,42 & 49,99 & 3,23 & 1,17 & 0,523 & N/SIG \\
\hline Co-A & 81,57 & 3,49 & 81,66 & 3,83 & 1,54 & 0,858 & N/SIG \\
\hline \multicolumn{8}{|c|}{ Componentes mandibulares } \\
\hline SNB & 76,62 & 2,91 & 77,51 & 2,93 & 0,88 & 0,000 & SIG** \\
\hline Co-Gn & 101,21 & 5,15 & 101,07 & 5,04 & 2,26 & 0,856 & N/SIG \\
\hline \multicolumn{8}{|c|}{ Relação maxilomandibulares } \\
\hline ANB & 7,49 & 2,12 & 7,40 & 1,96 & 0,57 & 0,613 & $\mathrm{~N} / \mathrm{SIG}$ \\
\hline \multicolumn{8}{|c|}{ Relações verticais } \\
\hline AFAI & 62,15 & 5,34 & 60,92 & 5,36 & 2,99 & 0,201 & N/SIG \\
\hline SN.GoMe & 39,25 & 5,22 & 38,11 & 5,91 & 2,58 & 0,168 & N/SIG \\
\hline SN.PP & 7,47 & 3,19 & & 2,68 & 1,61 & 0,232 & ISIG \\
\hline FRANK.Plo & 1,78 & 3,57 & 2,05 & 3,49 & 1,99 & 0,685 & /SIG \\
\hline PP.GoMe & 31,78 & 5,38 & 31 & 6,24 & 3,38 & 0,642 & N/SIG \\
\hline FRANK.GoMe &, 00 & 3,69 & & 4,94 & 2,71 & 0,383 & N/SIG \\
\hline Ar.GoMe & 46,06 & 4,92 & 45,89 & 5,55 & 2,62 & 0,844 & ISIG \\
\hline \multicolumn{8}{|c|}{ Componentes dentoalveolares superiores } \\
\hline 1.NA & 22,15 & 6,27 & 22,15 & 7,76 & 3,39 & 0,295 & N/SIG \\
\hline 1-PP & 27,07 & 2,90 & & 2,76 & 1,14 & 0,324 & N/SIG \\
\hline FHP-DI & 1 & 3,3 & 1 & 3,65 & 1,46 & 0,571 & ISIG \\
\hline FHP-ÁPICE $\underline{6}$ & 23,67 & 3,36 & 23,59 & 3,74 & 1,52 & 0,865 & N/SIG \\
\hline$\underline{6}$-PP & 20,34 & 1,71 & 19,70 & 2,13 & 1,19 & 0,086 & $\mathrm{~N} / \mathrm{SIG}$ \\
\hline \multicolumn{8}{|c|}{ Componentes dentoalveolares inferiores } \\
\hline$\overline{6}$-GoMe & 26,08 & 2,94 & 25,83 & 2,8 & 0,74 & 0,306 & $\mathrm{~N} / \mathrm{SIG}$ \\
\hline Me & 38,34 & 2,31 & 38,05 & 2,47 & 1,01 & 0,371 & N/SIG \\
\hline \multicolumn{8}{|c|}{ Componentes tegumentares } \\
\hline ANL & 111,84 & 10,48 & 112,79 & 9,44 & 5,49 & 0,597 & N/SIG \\
\hline $\mathrm{Li}$ & 1,96 & 2,04 & 2,31 & 2,27 & 0,71 & 0,118 & N/SIG \\
\hline Ls-E & 0,76 & 2,00 & 0,99 & 2,27 & 0,46 & 0,109 & $\mathrm{~N} / \mathrm{SIG}$ \\
\hline
\end{tabular}

N/SIG: não significante

SIG**: significante $(p<0,01)$ 

ANÁLISE DE VARIÂNCIA - ANOVA (tabela 4)

Na tabela 4, observa-se o resultado da análise de variância (ANOVA) na comparação intergrupos, na fase pré-tratamento, para determinar o grau de similaridade entre os três grupos estudados, quanto aos seus valores cefalométricos iniciais. 
TABELA 4: ANOVA - Análise de Variância entre os 3 grupos dos valores médios das medidas iniciais.

\begin{tabular}{|c|c|c|c|c|c|}
\hline \multirow{2}{*}{$\begin{array}{c}\text { Grandezas } \\
\text { Cefalométricas }\end{array}$} & \multicolumn{3}{|c|}{$\begin{array}{l}\text { Médias das medidas } \\
\text { iniciais }\end{array}$} & \multirow{2}{*}{$\begin{array}{l}\text { Análise de } \\
\text { Variância } \\
\text { P }\end{array}$} & \multirow[t]{2}{*}{ Significância } \\
\hline & $\begin{array}{c}\text { Grupo } \\
1\end{array}$ & $\begin{array}{c}\text { Grupo } \\
2\end{array}$ & $\begin{array}{c}\text { Grupo } \\
3\end{array}$ & & \\
\hline \multicolumn{6}{|c|}{ Componentes maxilares } \\
\hline SNA & 85,53 & 83,08 & 82,26 & 0,004 & SIG** \\
\hline FHP-A & 48,12 & 48,76 & 48,44 & 0,685 & N/SIG \\
\hline Co-A & 80,53 & 81,56 & 81,03 & 0,688 & N/SIG \\
\hline \multicolumn{6}{|c|}{ Componentes mandibulares } \\
\hline SNB & 78,17 & 75,33 & 77,00 & 0,004 & SIG** \\
\hline Co-Gn & 99,51 & 101,21 & 100,00 & 0,554 & N/SIG \\
\hline \multicolumn{6}{|c|}{ Relação maxilomandibulares } \\
\hline ANB & 7,35 & 7,75 & 5,25 & 0,000 & SIG** \\
\hline \multicolumn{6}{|c|}{ Relações verticais } \\
\hline AFAl & 59,63 & 64,70 & 58,65 & 0,000 & SIG** \\
\hline SN.GoMe & 36,12 & 41,13 & 33,98 & 0,000 & SIG** \\
\hline SN.PP & 6,21 & 6,65 & 6,54 & 0,861 & N/SIG \\
\hline FRANK.Plo & 2,32 & 3,24 & 2,27 & 0,462 & N/SIG \\
\hline PP.GoMe & 29,91 & 34,49 & 27,42 & 0,000 & $\mathrm{SIG}^{\star \star}$ \\
\hline FRANK.GoMe & 27,59 & 31,25 & 25,15 & 0,000 & SIG** \\
\hline Ar.GoMe & 48,40 & 44,89 & 49,88 & 0,001 & SIG** \\
\hline \multicolumn{6}{|c|}{ Componentes dentoalveolares superiores } \\
\hline 1.NA & 25,26 & 21,49 & 23,14 & 0,112 & N/SIG \\
\hline 1-PP & 23,16 & 24,11 & 24,09 & 0,378 & N/SIG \\
\hline FHP-D̄ISTAL 6 & 11,34 & 12,57 & 12,85 & 0,166 & N/SIG \\
\hline FHP-ÁPICE 6 & 19,40 & 20,46 & 19,10 & 0,060 & N/SIG \\
\hline$\underline{6}-\mathbf{P P}$ & 24,83 & 28,24 & 25,76 & 0,000 & SIG** \\
\hline \multicolumn{6}{|c|}{ Componentes dentoalveolares inferiores } \\
\hline$\overline{6}$-GoMe & 25,74 & 27,16 & 26,52 & 0,094 & N/SIG \\
\hline$\overline{1}$-GoMe & 36,82 & 39,66 & 36,66 & 0,001 & SIG** \\
\hline \multicolumn{6}{|c|}{ Componentes tegumentares } \\
\hline ANL & 114,88 & 106,96 & 116,32 & 0,006 & $\mathrm{SIG}^{\star \star}$ \\
\hline Li-E & 1,15 & 2,73 & $-0,66$ & 0,000 & SIG** \\
\hline LS-E & 1,00 & 1,24 & $-1,23$ & 0,000 & SIG** \\
\hline
\end{tabular}

N/SIG: não significante

SIG**: significante $(p<0,01)$ 
TABELA 5: Teste de Tukey entre os grupos 1 e 2 para comparação das medidas inciais das variáveis estatisticamente significantes verificadas pela análise de variância (ANOVA).

\begin{tabular}{|c|c|c|c|c|}
\hline \multirow{2}{*}{$\begin{array}{c}\text { Grandezas } \\
\text { Cefalométricas }\end{array}$} & \multicolumn{2}{|c|}{$\begin{array}{l}\text { Médias das } \\
\text { medidas } \\
\text { iniciais }\end{array}$} & \multirow{2}{*}{\begin{tabular}{|c|} 
Tuckey \\
P
\end{tabular}} & \multirow[t]{2}{*}{ Significância } \\
\hline & $\begin{array}{c}\text { Grupo } \\
1\end{array}$ & $\begin{array}{c}\text { Grupo } \\
2\end{array}$ & & \\
\hline \multicolumn{5}{|c|}{ Componentes maxilares } \\
\hline SNA & 85,53 & 83,08 & 0,040 & SIG* \\
\hline \multicolumn{5}{|c|}{ Componentes mandibulares } \\
\hline SNB & 78,17 & 75,33 & 0,003 & SIG** \\
\hline \multicolumn{5}{|c|}{ Relações maxilomandibulares } \\
\hline ANB & 7,35 & 7,75 & 0,775 & N/SIG \\
\hline \multicolumn{5}{|c|}{ Relações verticais } \\
\hline AFAI & 59,63 & 64,70 & 0,002 & SIG** \\
\hline SN.GoMe & 36,12 & 41,13 & 0,000 & SIG** \\
\hline PP.GoMe & 29,91 & 34,49 & 0,002 & SIG** \\
\hline FRANK.GoMe & 27,59 & 31,25 & 0,003 & SIG** \\
\hline Ar.GoMe & 48,40 & 44,89 & 0,026 & SIG* \\
\hline \multicolumn{5}{|c|}{ Componentes dentoalveolares superiores } \\
\hline 6-PP & 24,83 & 28,24 & 0,000 & SIG** \\
\hline \multicolumn{5}{|c|}{ Componentes dentoalveolares inferiores } \\
\hline$\overline{1}$-GoMe & 36,82 & 39,66 & 0,005 & $\mathrm{SIG}^{\star \star}$ \\
\hline \multicolumn{5}{|c|}{ Componentes tegumentares } \\
\hline ANL & 114,88 & 106,96 & 0,030 & $\mathrm{SIG}^{\star}$ \\
\hline LI-E & 1,15 & 2,73 & 0,064 & N/SIG \\
\hline LS-E & 1,00 & 1,24 & 0,899 & N/SIG \\
\hline
\end{tabular}

N/SIG: não significante

SIG*: significante $(p<0,05)$

SIG**: significante $(p<0,01)$ 
TABELA 6: Teste de Tukey entre os grupos 1 e 3 para comparação das medidas iniciais das variáveis estatisticamente significantes verificadas pela análise de variância.

\begin{tabular}{|c|c|c|c|c|}
\hline Grandezas & \multicolumn{2}{|c|}{$\begin{array}{l}\text { Médias das } \\
\text { medidas } \\
\text { iniciais }\end{array}$} & \multirow{2}{*}{$\begin{array}{c}\text { Tuckey } \\
\text { P }\end{array}$} & \multirow[t]{2}{*}{ Significância } \\
\hline Cefalométricas & $\begin{array}{c}\text { Grupo } \\
1\end{array}$ & $\begin{array}{c}\text { Grupo } \\
3\end{array}$ & & \\
\hline \multicolumn{5}{|c|}{ Componentes maxilares } \\
\hline SNA & 85,53 & 82,26 & 0,004 & SIG** \\
\hline \multicolumn{5}{|c|}{ Componentes mandibulares } \\
\hline SNB & 78,17 & 77,00 & 0,346 & $\mathrm{~N} / \mathrm{SIG}$ \\
\hline \multicolumn{5}{|c|}{ Relações maxilomandibulares } \\
\hline ANB & 7,35 & 5,25 & 0,002 & SIG** \\
\hline \multicolumn{5}{|c|}{ Relações verticais } \\
\hline AFAI & 59,63 & 58,65 & 0,764 & N/SIG \\
\hline SN.GoMe & 36,12 & 33,98 & 0,171 & N/SIG \\
\hline PP.GoMe & 29,91 & 27,42 & 0,132 & N/SIG \\
\hline FRANK.GoMe & 27,59 & 25,15 & 0,062 & N/SIG \\
\hline Ar.GoMe & 48,40 & 49,88 & 0,501 & $\mathrm{~N} / \mathrm{SIG}$ \\
\hline \multicolumn{5}{|c|}{ Componentes dentoalveolares superiores } \\
\hline 6-PP & 24,83 & 25,76 & 0,433 & $\mathrm{~N} / \mathrm{SIG}$ \\
\hline \multicolumn{5}{|c|}{ Componentes dentoalveolares inferiores } \\
\hline$\overline{1}$-GoMe & 36,82 & 36,66 & 0,981 & N/SIG \\
\hline \multicolumn{5}{|c|}{ Componentes tegumentares } \\
\hline ANL & 114,88 & 116,32 & 0,885 & N/SIG \\
\hline LI-E & 1,15 & $-0,66$ & 0,029 & $\mathrm{SIG}^{\star}$ \\
\hline LS-E & 1,00 & $-1,23$ & 0,000 & SIG** \\
\hline
\end{tabular}

N/SIG: não significante

SIG*: significante $(p<0,05)$

SIG**: significante $(p<0,01)$ 
TABELA 7: Teste Tukey entre os grupos 2 e 3 para comparação das medidas iniciais das variáveis estatisticamente significantes verificadas pela análise de variância.

\begin{tabular}{|c|c|c|c|c|}
\hline \multirow{2}{*}{$\begin{array}{c}\text { Grandezas } \\
\text { Cefalométricas }\end{array}$} & \multicolumn{2}{|c|}{$\begin{array}{l}\text { Médias das } \\
\text { medidas } \\
\text { iniciais }\end{array}$} & \multirow{2}{*}{\begin{tabular}{|c|} 
Tuckey \\
P
\end{tabular}} & \multirow[t]{2}{*}{ Significância } \\
\hline & $\begin{array}{c}\text { Grupo } \\
2\end{array}$ & $\begin{array}{c}\text { Grupo } \\
3\end{array}$ & & \\
\hline \multicolumn{5}{|c|}{ Componentes maxilares } \\
\hline SNA & 83,08 & 82,26 & 0,685 & N/SIG \\
\hline \multicolumn{5}{|c|}{ Componentes mandibulares } \\
\hline SNB & 75,33 & 77,00 & 0,114 & $\mathrm{~N} / \mathrm{SIG}$ \\
\hline \multicolumn{5}{|c|}{ Relações maxilomandibulares } \\
\hline ANB & 7,75 & 5,25 & 0,000 & SIG** \\
\hline \multicolumn{5}{|c|}{ Relações verticais } \\
\hline AFAl & 64,70 & 58,65 & 0,000 & SIG** \\
\hline SN.GoMe & 41,13 & 33,98 & 0,114 & N/SIG \\
\hline PP.GoMe & 34,49 & 27,42 & 0,000 & $\mathrm{SIG}^{\star *}$ \\
\hline FRANK.GoMe & 31,25 & 25,15 & 0,000 & SIG** \\
\hline Ar.GoMe & 44,89 & 49,88 & 0,001 & SIG** \\
\hline \multicolumn{5}{|c|}{ Componentes dentoalveolares superiores } \\
\hline 6-PP & 28,24 & 25,76 & 0,004 & SIG** \\
\hline \multicolumn{5}{|c|}{ Componentes dentoalveolares inferiores } \\
\hline$\overline{1}$-GoMe & 39,66 & 36,66 & 0,003 & $\mathrm{SIG}^{* *}$ \\
\hline \multicolumn{5}{|c|}{ Componentes tegumentares } \\
\hline ANL & 106,96 & 116,32 & 0,008 & SIG** \\
\hline LI-E & 2,73 & $-0,66$ & 0,000 & SIG** \\
\hline LS-E & 1,24 & $-1,23$ & 0,000 & SIG** \\
\hline
\end{tabular}

N/SIG: não significante

SIG*: significante $(p<0,05)$

SIG**: significante $(p<0,01)$ 


\section{3}

COMPARAÇÃO INTERGRUPOS DAS ALTERAÇÕES MÉDIAS PELA ANÁLISE DE VARIÂNCIA - ANOVA (tabela 8)

$\mathrm{Na}$ tabela 8 observa-se que a maioria das grandezas cefalométricas obtiveram diferenças estatisticamente significantes, mostrando deste modo, que as alterações médias entre os três grupos mostraram-se bastante distintas. 
TABELA 8: ANOVA - Análise de Variância entre os 3 grupos das diferenças das médias das alterações finais e iniciais.

\begin{tabular}{|c|c|c|c|c|c|}
\hline \multirow{2}{*}{$\begin{array}{c}\text { Grandezas } \\
\text { Cefalométricas }\end{array}$} & \multicolumn{3}{|c|}{ Médias das alterações } & \multirow{2}{*}{$\begin{array}{c}\begin{array}{c}\text { Análise de } \\
\text { Variância }\end{array} \\
\mathbf{P}\end{array}$} & \multirow[t]{2}{*}{ Significância } \\
\hline & $\begin{array}{c}\text { Grupo } \\
1\end{array}$ & $\begin{array}{c}\text { Grupo } \\
2\end{array}$ & $\begin{array}{c}\text { Grupo } \\
3\end{array}$ & & \\
\hline \multicolumn{6}{|c|}{ Componentes maxilares } \\
\hline SNA & $-0,47$ & $-1,40$ & $-0,12$ & 0,122 & $\mathrm{~N} / \mathrm{SIG}$ \\
\hline FHP-A & 0,40 & 0,04 & 2,83 & 0,000 & SIG** \\
\hline Co-A & 0,35 & $-0,75$ & 1,56 & 0,000 & SIG** \\
\hline \multicolumn{6}{|c|}{ Componentes mandibulares } \\
\hline SNB & 0,62 & 0,26 & 0,20 & 0,795 & N/SIG \\
\hline Co-Gn & 3,72 & 2,31 & 2,03 & 0,025 & $\mathrm{SIG}^{*}$ \\
\hline \multicolumn{6}{|c|}{ Relação maxilomandibulares } \\
\hline ANB & $-1,09$ & $-1,67$ & $-0,32$ & 0,008 & SIG** \\
\hline \multicolumn{6}{|c|}{ Relações verticais } \\
\hline AFAl & 0,82 & 0,87 & 1,08 & 0,886 & $\mathrm{~N} / \mathrm{SIG}$ \\
\hline SN.GoMe & $-1,68$ & $-0,36$ & $-0,82$ & 0,166 & $\mathrm{~N} / \mathrm{SIG}$ \\
\hline SN.PP & 0,10 & 0,36 & 0,70 & 0,710 & N/SIG \\
\hline FRANK.PIo & $-1,48$ & $-1,27$ & $-0,64$ & 0,442 & N/SIG \\
\hline PP.GoMe & $-1,78$ & $-0,74$ & $-1,52$ & 0,344 & $\mathrm{~N} / \mathrm{SIG}$ \\
\hline FRANK.GoMe & $-0,30$ & 0,53 & $-0,88$ & 0,078 & N/SIG \\
\hline Ar.GoMe & 1,24 & 1,55 & 1,20 & 0,902 & N/SIG \\
\hline \multicolumn{6}{|c|}{ Componentes dentoalveolares superiores } \\
\hline 1.NA & $-5,20$ & 0,95 & 0,64 & 0,000 & SIG** \\
\hline 1-PP & 0,61 & 0,52 & 0,66 & 0,917 & N/SIG \\
\hline FHP-D̄ISTAL 6 & $-1,26$ & $-1,89$ & 0,98 & 0,000 & SIG** \\
\hline FHP-ÁPICE 6 & $-1,63$ & $-2,14$ & 0,90 & 0,000 & SIG** \\
\hline 6-PP & 0,63 & 0,10 & 0,94 & 0,101 & N/SIG \\
\hline \multicolumn{6}{|c|}{ Componentes dentoalveolares inferiores } \\
\hline$\overline{6}$-GoMe & 1,03 & 1,08 & 0,76 & 0,699 & N/SIG \\
\hline 1-GoMe & 0,53 & 0,84 & 1,16 & 0,225 & N/SIG \\
\hline \multicolumn{6}{|c|}{ Componentes tegumentares } \\
\hline ANL & 2,50 & 0,95 & 3,07 & 0,752 & N/SIG \\
\hline Li-E & $-0,83$ & $-0,56$ & $-0,17$ & 0,359 & $\mathrm{~N} / \mathrm{SIG}$ \\
\hline LS-E & $-1,87$ & $-1,57$ & $-0,38$ & 0,002 & $\mathrm{SIG}^{* *}$ \\
\hline
\end{tabular}

N/SIG: não significante

SIG*: significante $(p<0,05)$

SIG**: significante $(p<0,01)$ 
TABELA 9: Teste de Tukey entre os grupos 1 e 2 para comparação das médias das alterações.

\begin{tabular}{|c|c|c|c|c|}
\hline Grandezas & \multicolumn{2}{|c|}{$\begin{array}{l}\text { Médias das } \\
\text { alterações }\end{array}$} & \multirow{2}{*}{$\begin{array}{c}\text { Tuckey } \\
\text { P }\end{array}$} & \multirow[t]{2}{*}{ Significância } \\
\hline Cefalométricas & $\begin{array}{c}\text { Grupo } \\
1\end{array}$ & $\begin{array}{c}\text { Grupo } \\
2\end{array}$ & & \\
\hline \multicolumn{5}{|c|}{ Componentes maxilares } \\
\hline Co-A & 0,40 & 0,04 & 0,774 & N/SIG \\
\hline FHP-A & 0,35 & $-0,75$ & 0,068 & N/SIG \\
\hline \multicolumn{5}{|c|}{ Componentes mandibulares } \\
\hline Co-Gn & 3,72 & 2,31 & 0,903 & N/SIG \\
\hline \multicolumn{5}{|c|}{ Relações maxilomandibulares } \\
\hline ANB & $-1,09$ & $-1,67$ & 0,353 & N/SIG \\
\hline \multicolumn{5}{|c|}{ Componentes dentoalveolares superiores } \\
\hline 1.NA & $-5,20$ & 0,95 & 0,000 & SIG** \\
\hline FHP-DISTAL $\underline{6}$ & $-1,26$ & $-1,89$ & 0,589 & N/SIG \\
\hline FHP-ÁPICE $\underline{6}$ & $-1,63$ & $-2,14$ & 0,676 & N/SIG \\
\hline \multicolumn{5}{|c|}{ Componentes tegumentares } \\
\hline LS-E & $-1,87$ & $-1,57$ & 0,755 & N/SIG \\
\hline
\end{tabular}

N/SIG: não significante

SIG*: significante $(p<0,05)$

SIG**: significante $(p<0,01)$ 
TABELA 10: Teste de Tukey entre os grupos 1 e 3 para comparação das médias das alterações.

\begin{tabular}{|c|c|c|c|c|}
\hline \multirow{2}{*}{$\frac{\text { Grandezas }}{\text { Cefalométricas }}$} & \multicolumn{2}{|c|}{$\begin{array}{l}\text { Médias das } \\
\text { alterações }\end{array}$} & \multirow{2}{*}{$\begin{array}{c}\text { Tuckey } \\
\text { P }\end{array}$} & \multirow[t]{2}{*}{ Significância } \\
\hline & $\begin{array}{c}\text { Grupo } \\
1\end{array}$ & $\begin{array}{c}\text { Grupo } \\
3\end{array}$ & & \\
\hline \multicolumn{5}{|c|}{ Componentes maxilares } \\
\hline Co-A & 0,40 & 2,83 & 0,000 & SIG** \\
\hline FHP-A & 0,35 & 1,56 & 0,040 & SIG* \\
\hline \multicolumn{5}{|c|}{ Componentes mandibulares } \\
\hline Co-Gn & 3,72 & 2,03 & 0,031 & $\mathrm{SIG}^{\star}$ \\
\hline \multicolumn{5}{|c|}{ Relações maxilomandibulares } \\
\hline ANB & $-1,09$ & $-0,32$ & 0,165 & N/SIG \\
\hline \multicolumn{5}{|c|}{ Componentes dentoalveolares superiores } \\
\hline 1.NA & $-5,20$ & 0,64 & 0,001 & SIG** \\
\hline FHP-DISTAL 6 & $-1,26$ & 0,98 & 0,002 & SIG** \\
\hline FHP-ÁPICE $\underline{6}$ & $-1,63$ & 0,90 & 0,000 & SIG** \\
\hline \multicolumn{5}{|c|}{ Componentes tegumentares } \\
\hline LS-E & $-1,87$ & $-0,38$ & 0,002 & SIG** \\
\hline
\end{tabular}

N/SIG: não significante

SIG*: significante $(p<0,05)$

SIG**: significante $(p<0,01)$ 
TABELA 11: Teste de Tukey entre os grupos 2 e 3 para comparação das médias das alterações.

\begin{tabular}{|c|c|c|c|c|}
\hline \multirow{2}{*}{$\frac{\text { Grandezas }}{\text { Cefalométricas }}$} & \multicolumn{2}{|c|}{$\begin{array}{l}\text { Médias das } \\
\text { alterações }\end{array}$} & \multirow{2}{*}{$\frac{\text { Tuckey }}{\text { P }}$} & \multirow[t]{2}{*}{ Significância } \\
\hline & $\begin{array}{c}\text { Grupo } \\
2\end{array}$ & $\begin{array}{c}\text { Grupo } \\
3\end{array}$ & & \\
\hline \multicolumn{5}{|c|}{ Componentes maxilares } \\
\hline Co-A & 0,04 & 2,83 & 0,000 & SIG** \\
\hline FHP-A & $-0,75$ & 1,56 & 0,000 & SIG** \\
\hline \multicolumn{5}{|c|}{ Componentes mandibulares } \\
\hline Co-Gn & 2,31 & 2,03 & 0,085 & $\mathrm{~N} / \mathrm{SIG}$ \\
\hline \multicolumn{5}{|c|}{ Relações maxilomandibulares } \\
\hline ANB & $-1,67$ & $-0,32$ & 0,005 & SIG** \\
\hline \multicolumn{5}{|c|}{ Componentes dentoalveolares superiores } \\
\hline 1.NA & 0,95 & 0,64 & 0,978 & $\mathrm{~N} / \mathrm{SIG}$ \\
\hline FHP-DISTAL $\underline{6}$ & $-1,89$ & 0,98 & 0,000 & SIG** \\
\hline FHP-ÁPICE $\underline{6}$ & $-2,14$ & 0,90 & 0,000 & SIG** \\
\hline \multicolumn{5}{|c|}{ Componentes tegumentares } \\
\hline LS-E & $-1,57$ & $-0,38$ & 0,017 & SIG* $^{*}$ \\
\hline
\end{tabular}

N/SIG: não significante

SIG*: significante $(p<0,05)$

SIG**: significante $(p<0,01)$ 
Representações gráficas entre os 3 grupos das diferenças das médias das alterações finais e iniciais.

\section{Componentes maxilares:}

Nas alterações observadas por meio dos componentes maxilares, constatou-se que os grupos tratados apresentaram maior restrição do deslocamento anterior da maxila, assim como restrição também no aumento de seu comprimento efetivo, quando comparados com o grupo sem tratamento, expresso pelas grandezas SNA, FHP-A e Co-A.

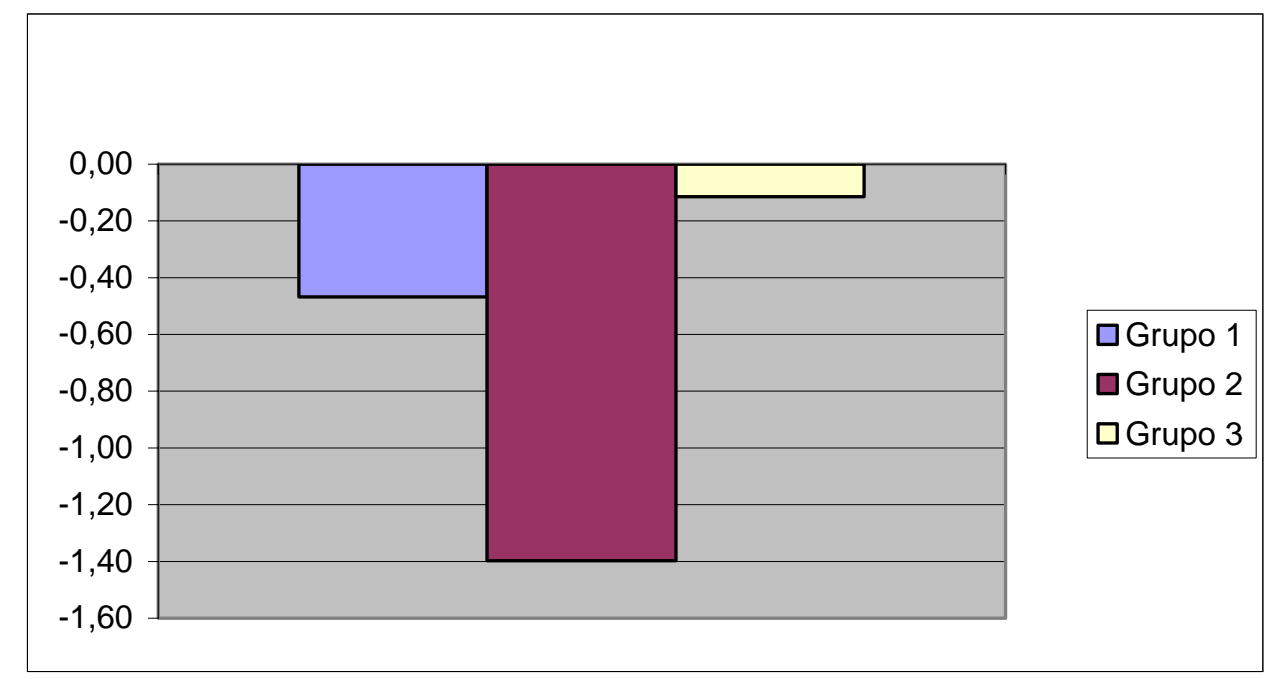

FIGURA 6: Alterações do ângulo SNA nos três grupos. 


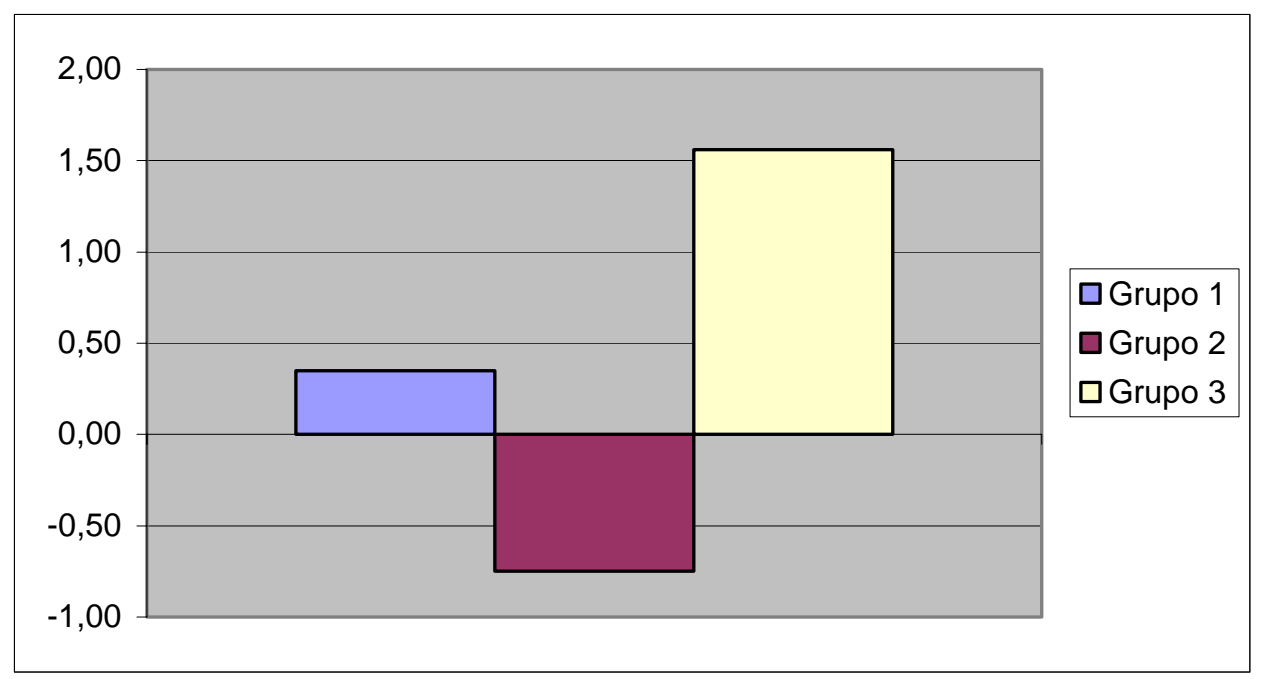

FIGURA 7: Alterações da variável FHp-A nos três grupos.

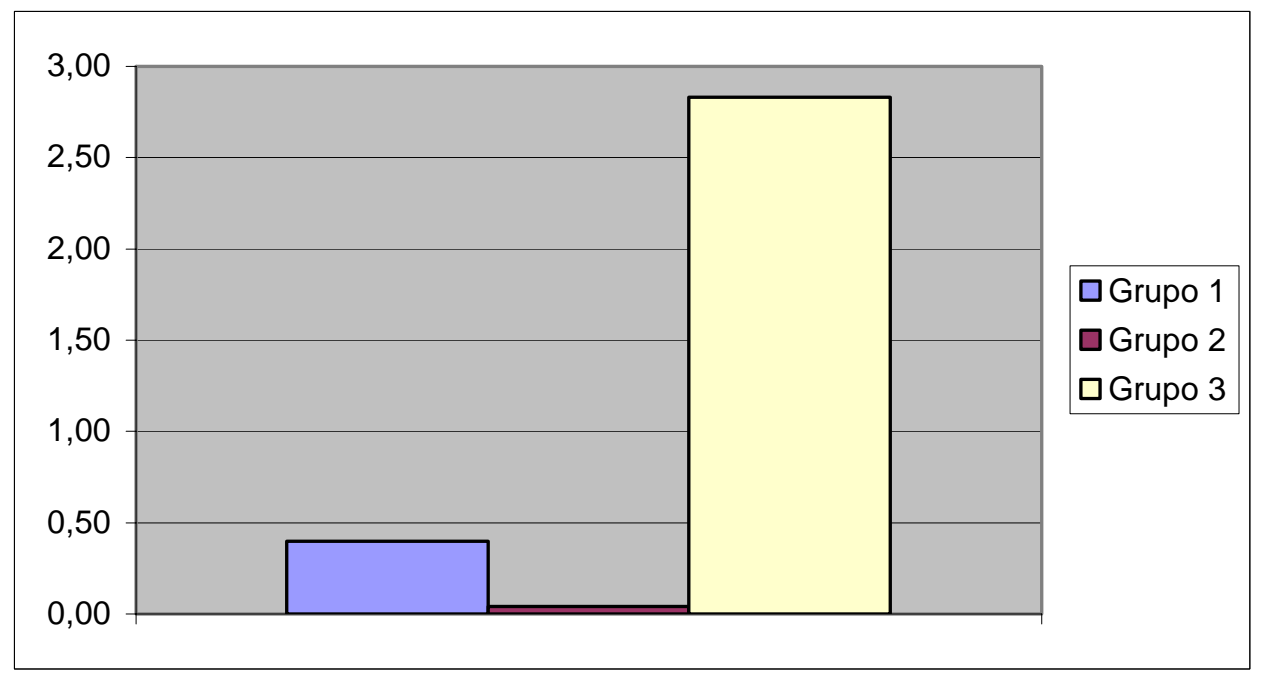

FIGURA 8: Grandeza Co-A para os três grupos.

Componentes mandibulares:

Ao analisar o deslocamento para anterior da mandíbula, por meio da variável cefalométrica SNB, verificou-se que houve um maior deslocamento nos grupos tratados, sendo mais significante no grupo tratado com o aparelho AEB conjugado. Já com relação ao comprimento efetivo da mandíbula, constatou-se um aumento maior no grupo sem tratamento, porém com valor estatisticamente significante, ao analisar a grandeza Co-Gn. 


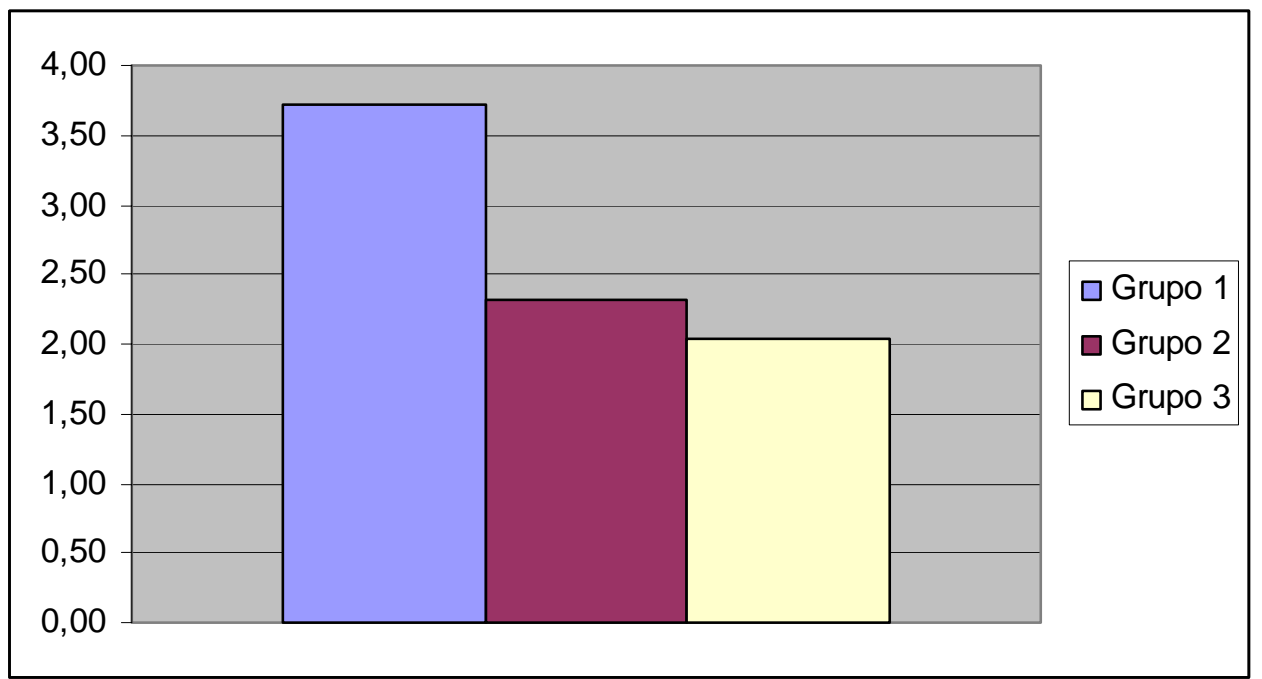

FIGURA 9: Alteração da medida Co-Gn nos três grupos.

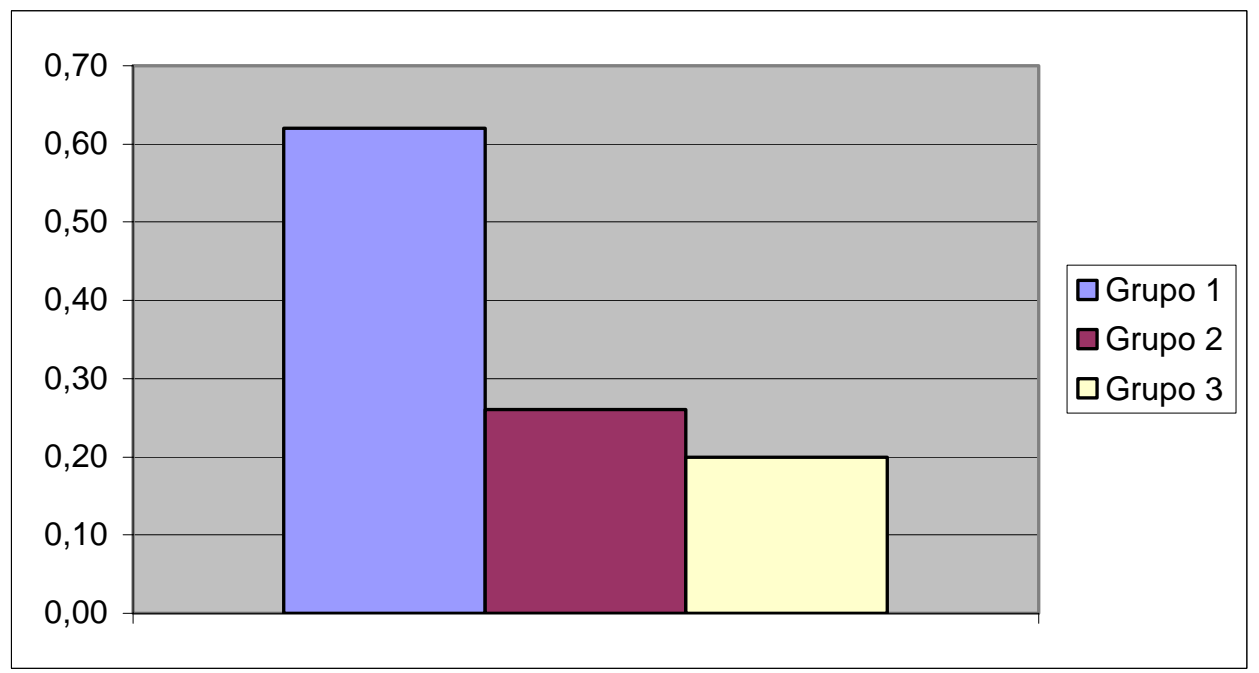

FIGURA 10: Alteração do ângulo SNB nos três grupos.

Relação maxilomandibular:

Ao verificar a relação maxilomandibular por meio da grandeza ANB, observou-se que houve uma redução do ângulo ANB mais significante nos grupos experimentais. 


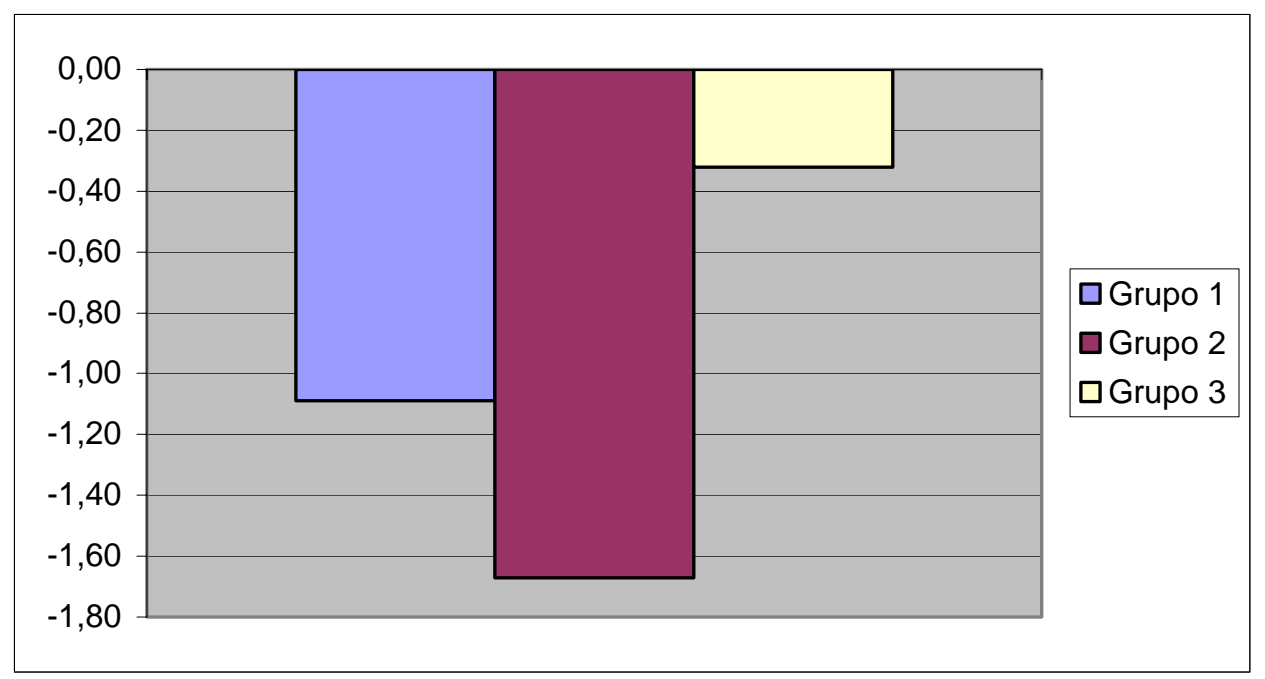

FIGURA 11: Alteração do ângulo ANB nos três grupos.

Relações verticais:

Com relação aos componentes verticais verificados, observou-se que não houve alterações estatisticamente significantes comparando os grupos tratados e o controle.

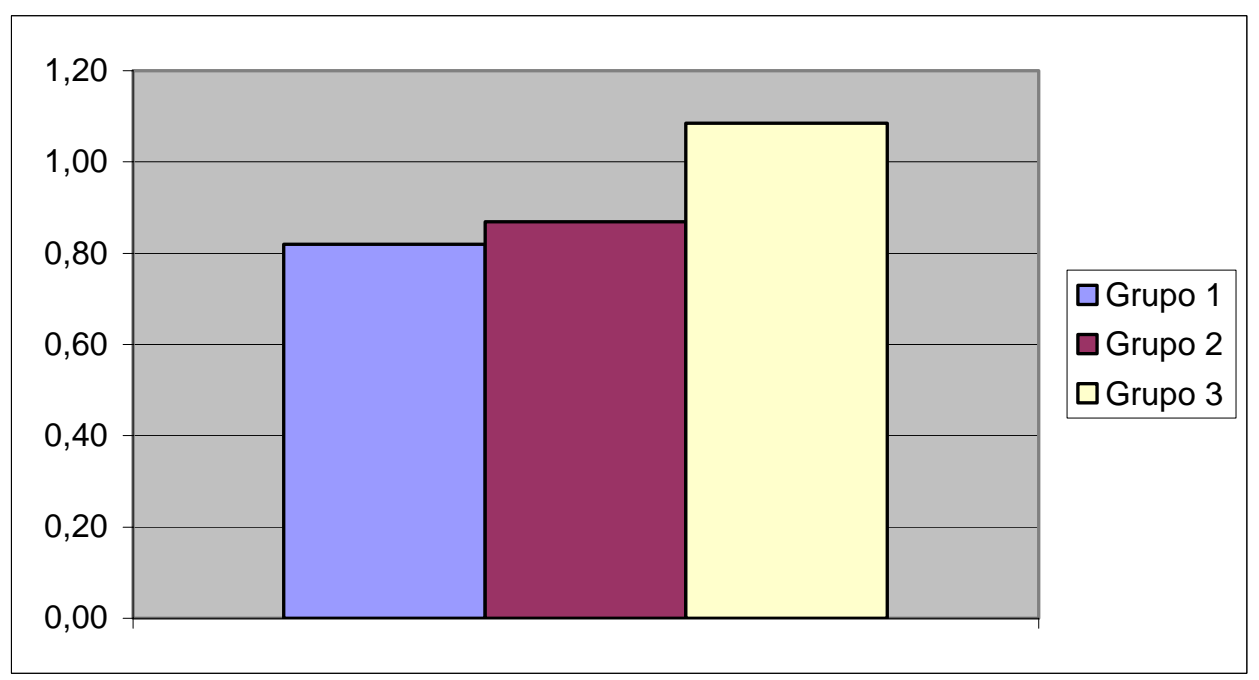

FIGURA 12: Alterações da AFAI nos três grupos. 


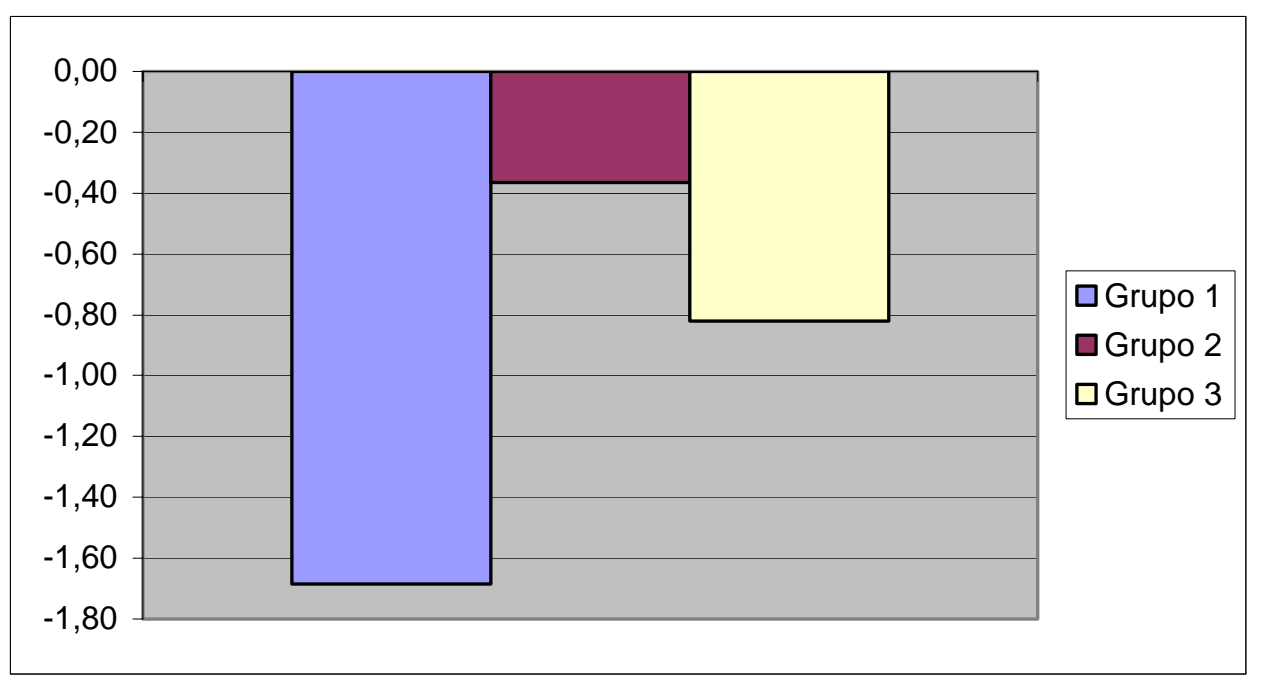

FIGURA 13: Alterações do ângulo SN.GoMe nos três grupos.

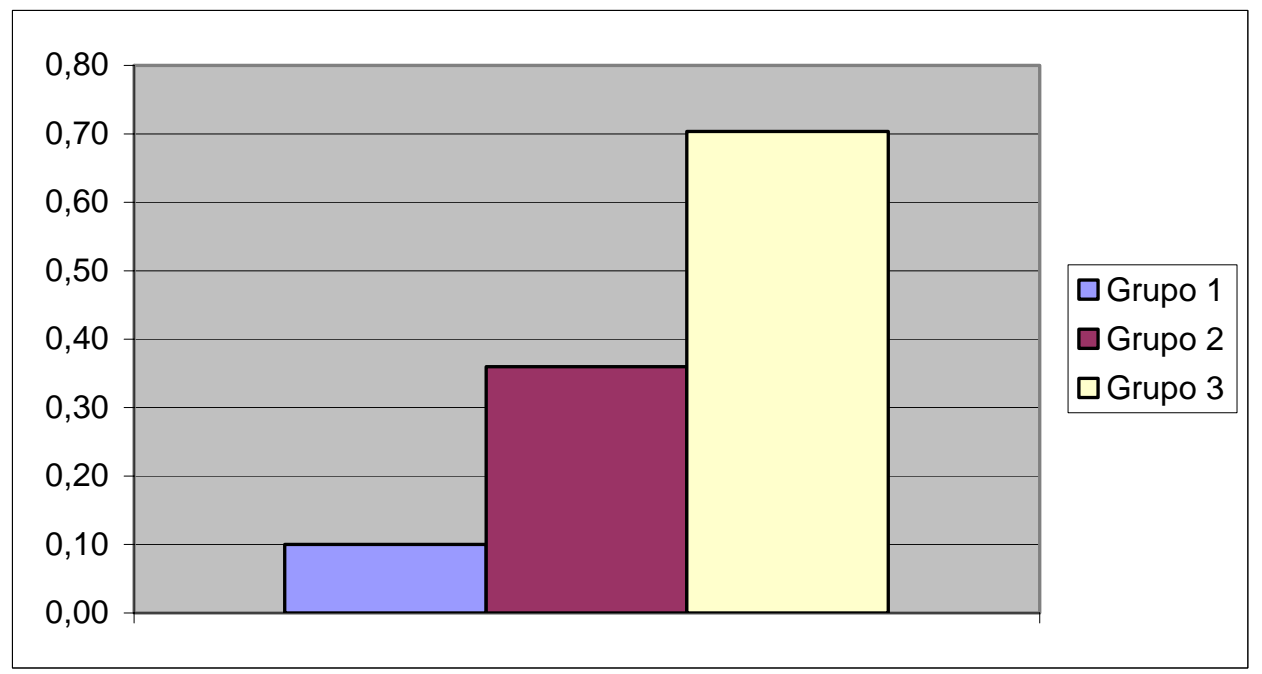

FIGURA 14: Alterações da grandeza SN.PP nos três grupos. 


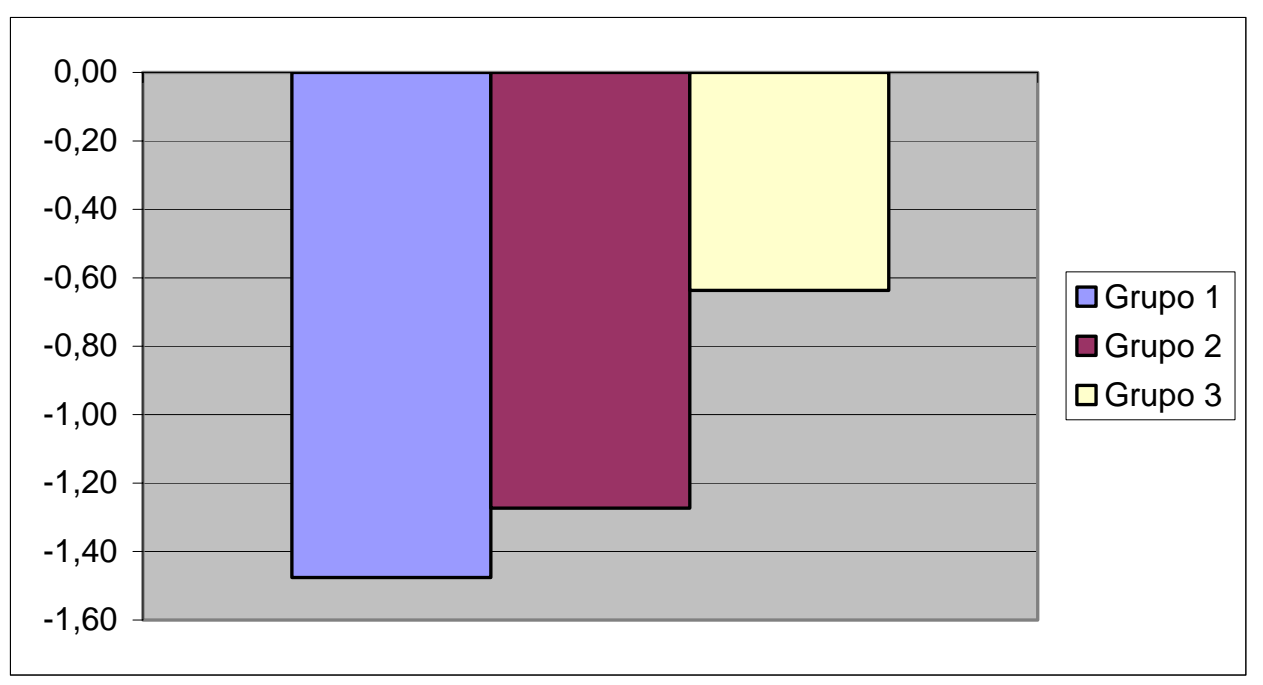

FIGURA 15: Alterações do ângulo FRANK.Plo nos três grupos.

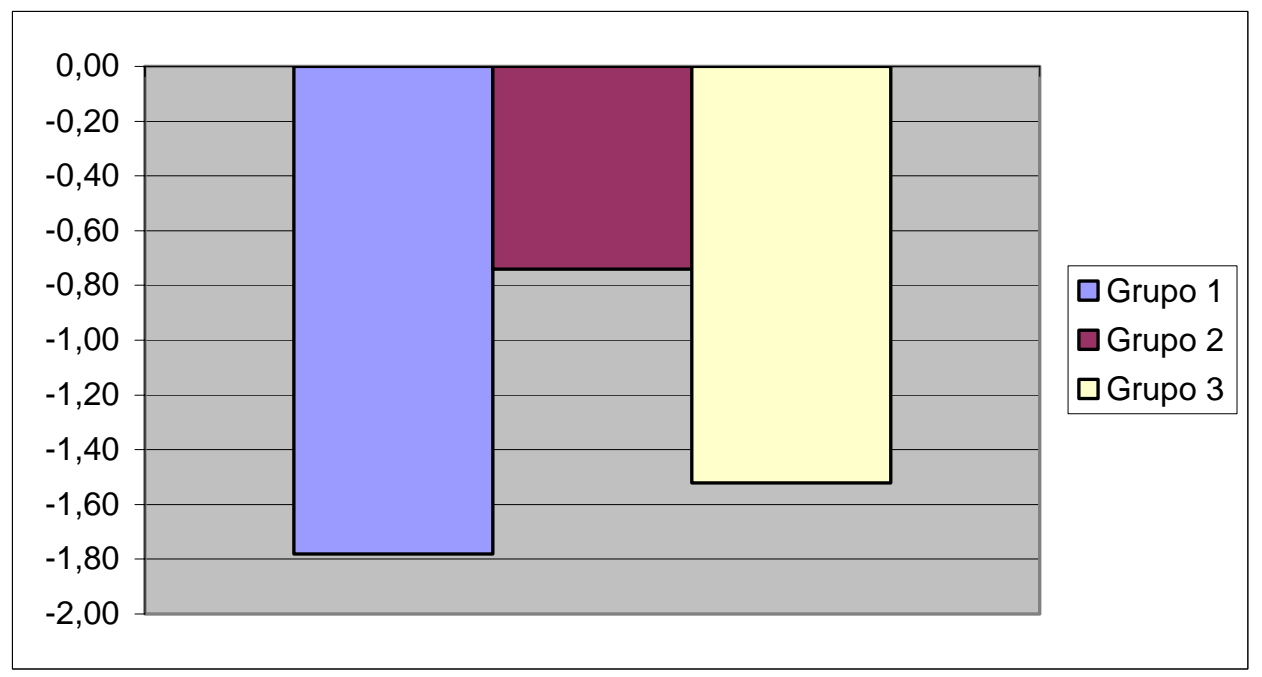

FIGURA 16: Alterações do ângulo PP.GoMe nos três grupos. 


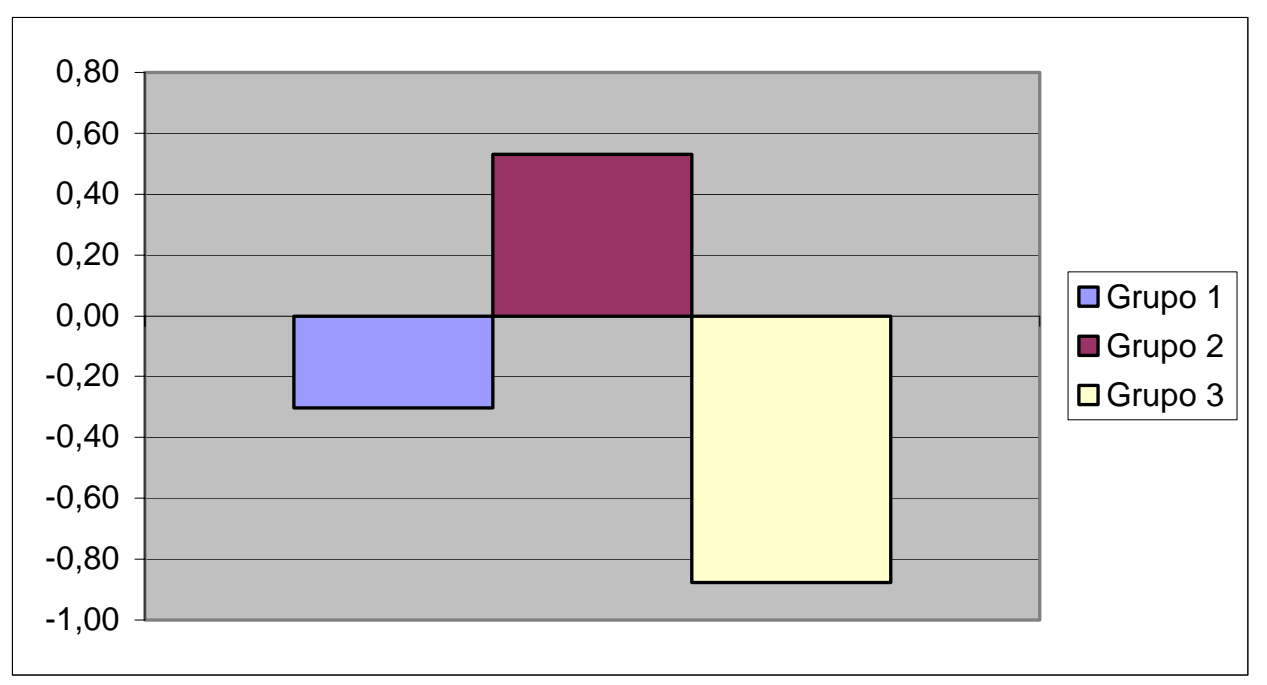

FIGURA 17: Alterações na grandeza FRANK.GoMe (FMA) nos três grupos.

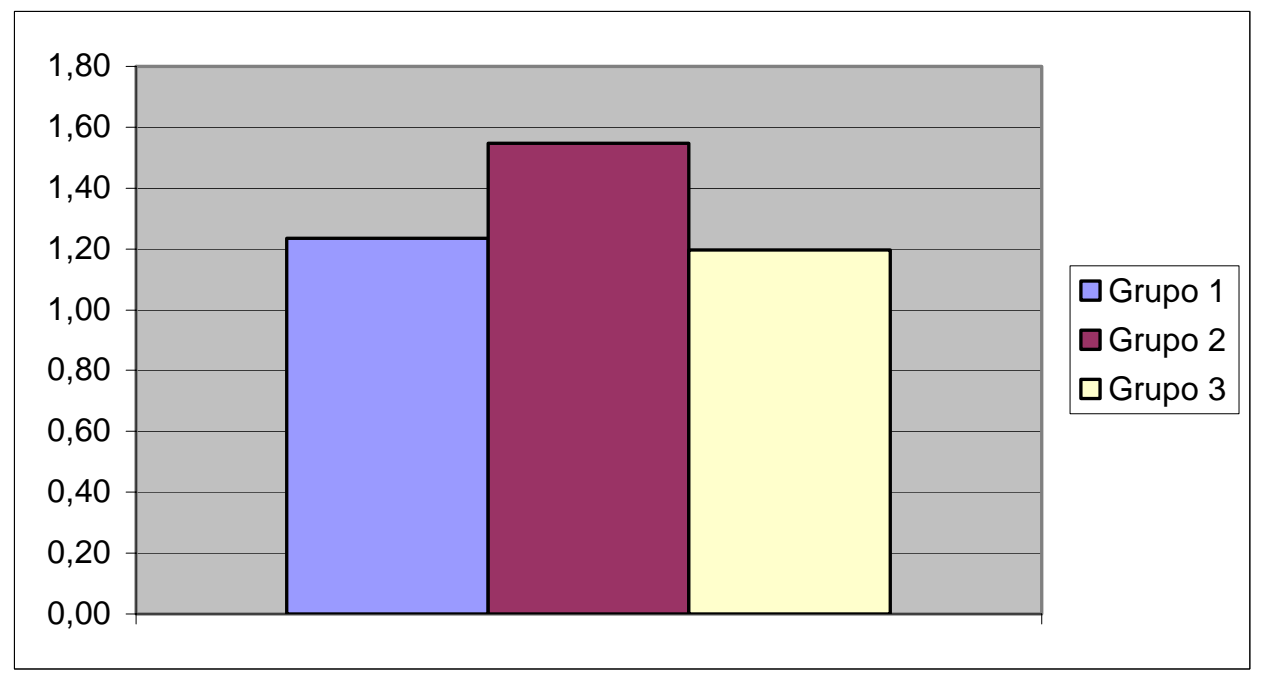

FIGURA 18: Alterações do ângulo Ar.GoMe nos três grupos.

Componentes dentoalveolares superiores:

Ao avaliar as alterações demonstradas por meio dos componentes dentoalveolares superiores, obtém-se que os incisivos superiores sofreram uma menor extrusão nos grupos experimentais, estatisticamente não significante. Já com relação à inclinação dos incisivos superiores, houve diminuição desta somente no grupo tratado com o aparelho AEB conjugado, estatisticamente significante. Ao estudar a movimentação dos molares 
superiores, nota-se que no grupo controle houve mesialização destes dentes. Já nos grupos experimentais, ocorreu uma movimentação para distal destes dentes, tanto de coroa quanto de raiz. Com relação à extrusão dos molares superiores, constata-se que nos grupos experimentais houve uma maior restrição, porém estatisticamente insignificante.

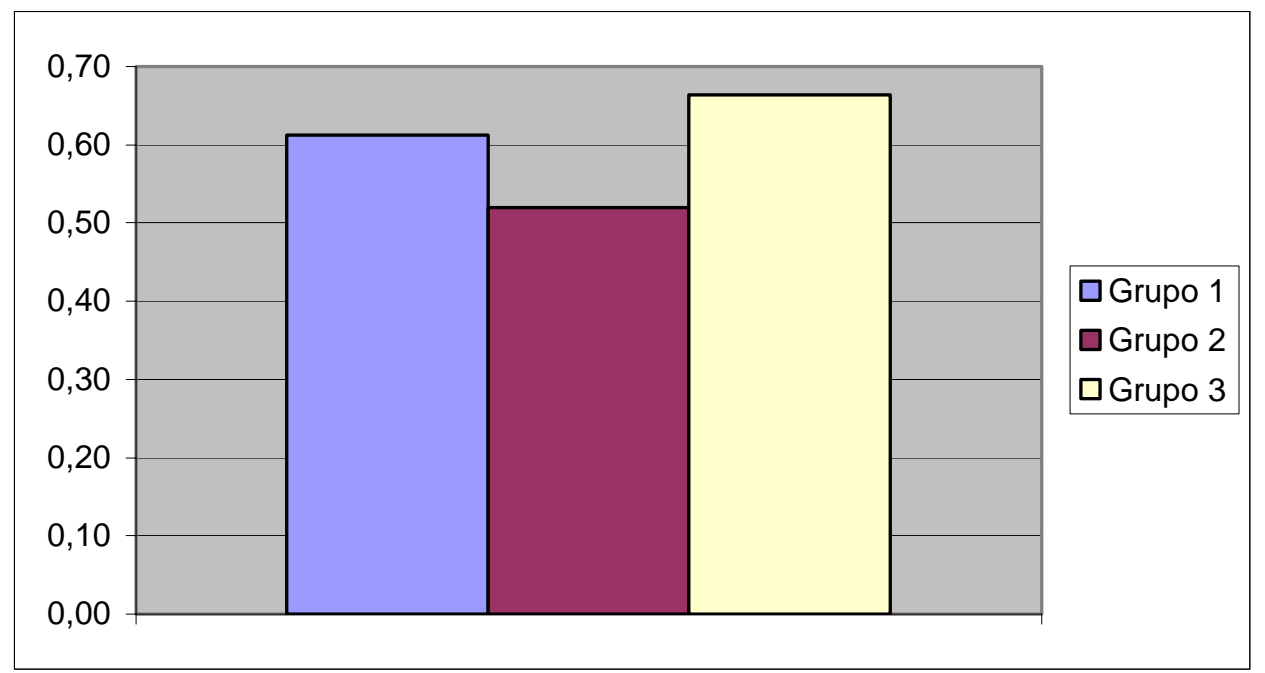

FIGURA 19: Alterações da medida 1-PP nos três grupos.

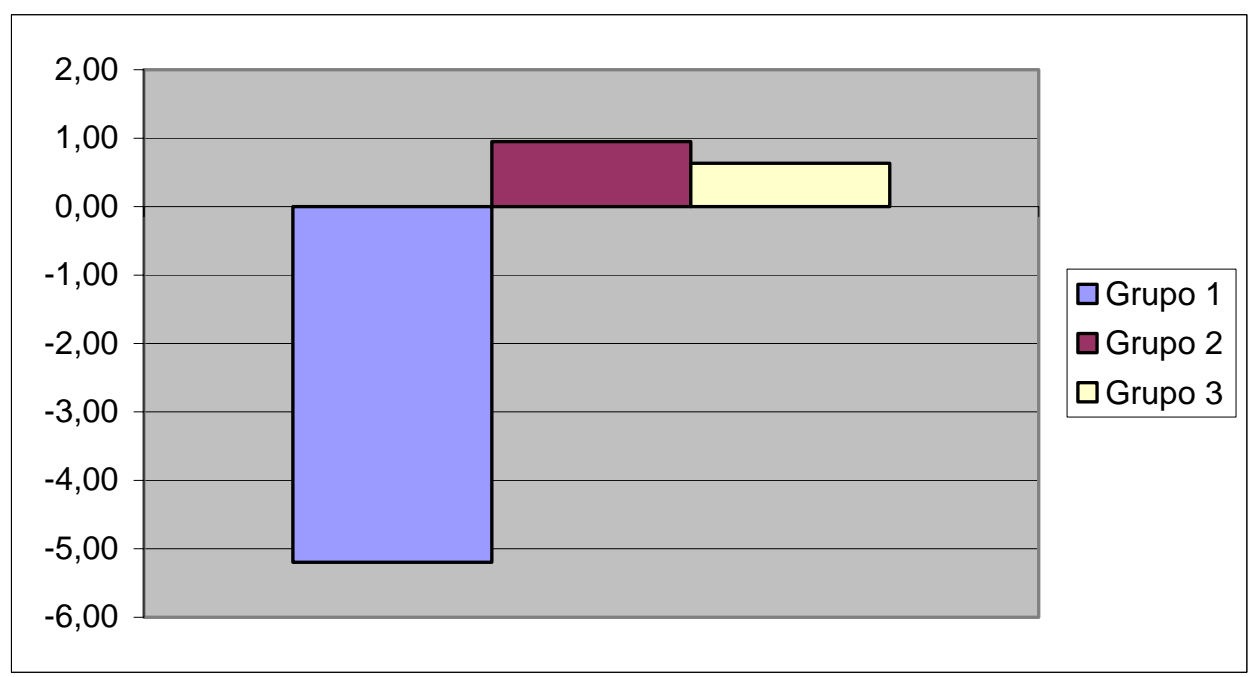

FIGURA 20: Alterações do ângulo 1. NA nos três grupos. 


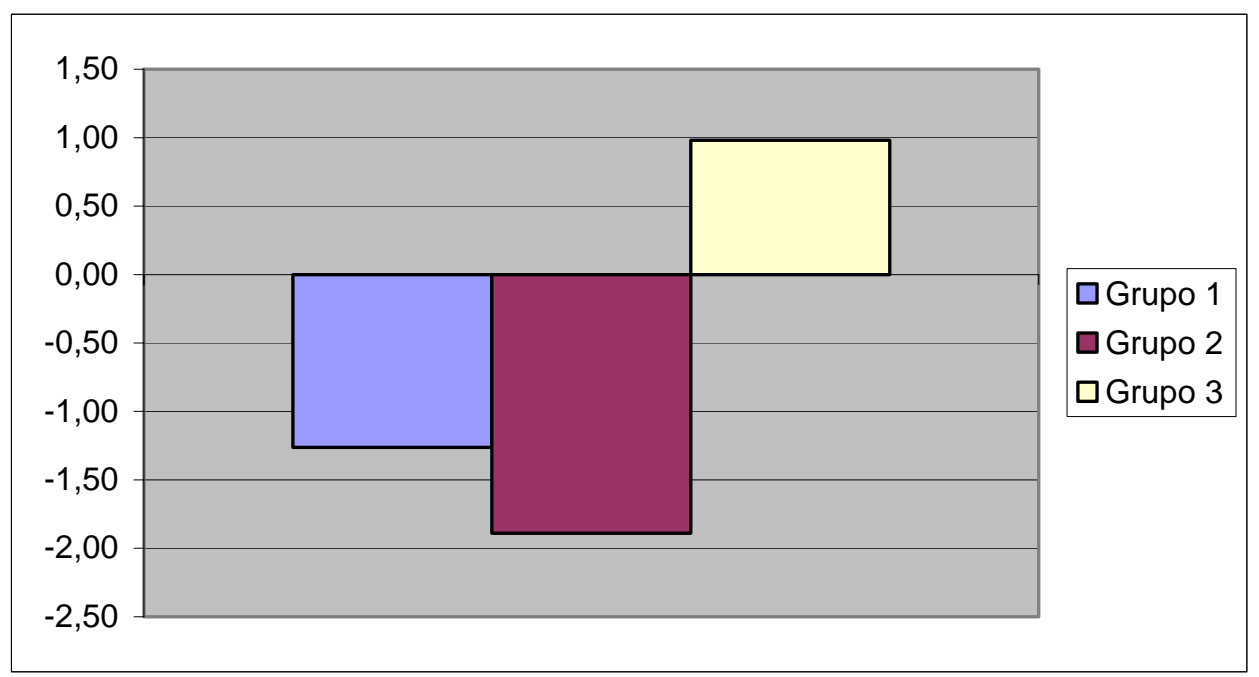

FIGURA 21: Alterações da medida FHP-DISTAL $\underline{6}$ nos três grupos.

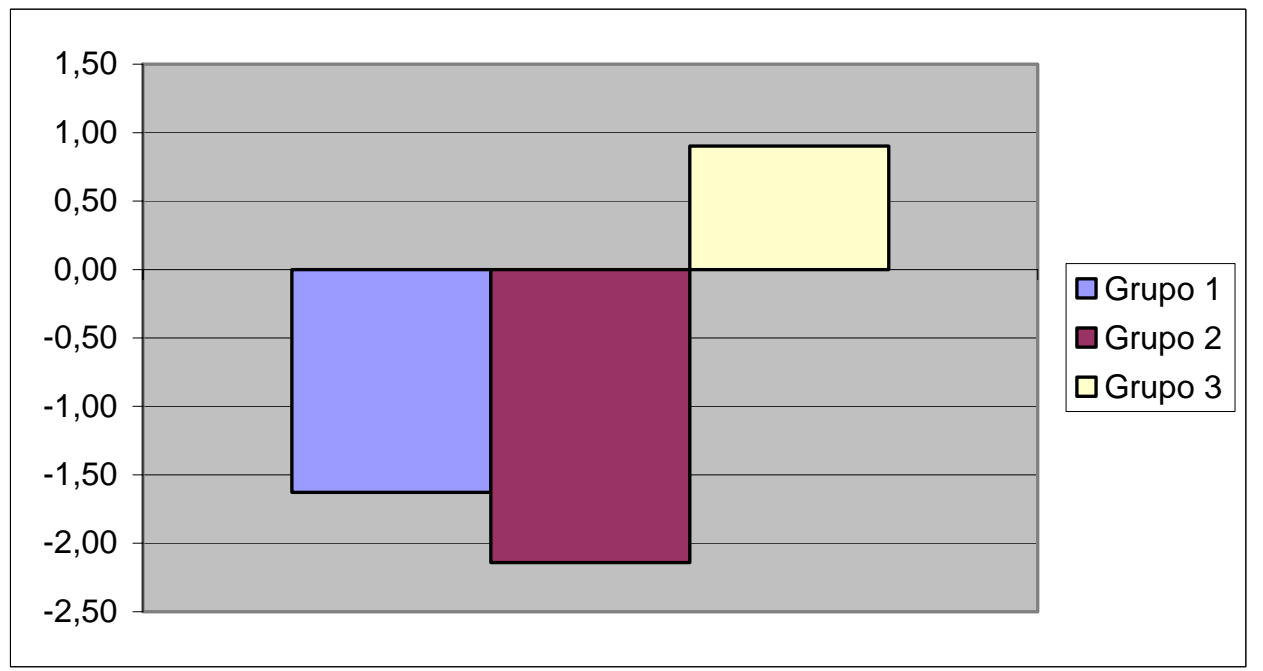

FIGURA 22: Alterações na medida FHP-ÁPICE $\underline{6}$ nos três grupos. 


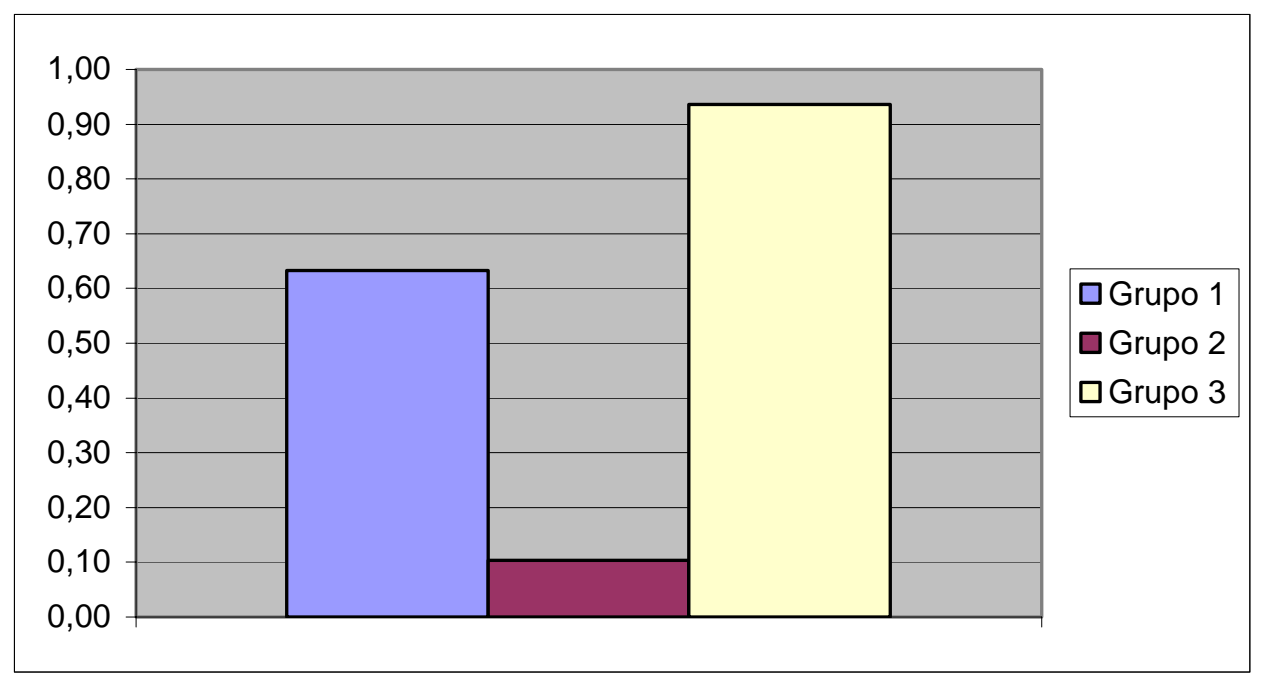

FIGURA 23: Alterações da medida $\underline{6}-\mathrm{PP}$ nos três grupos.

Componentes dentoalveolares inferiores:

Ao avaliar a extrusão dos molares inferiores, e obtém-se um valor menor no grupo controle. Já com relação à extrusão dos incisivos inferiores, ocorreu exatamente o contrário, houve uma extrusão maior justamente no grupo controle, porém sem significância estatística.

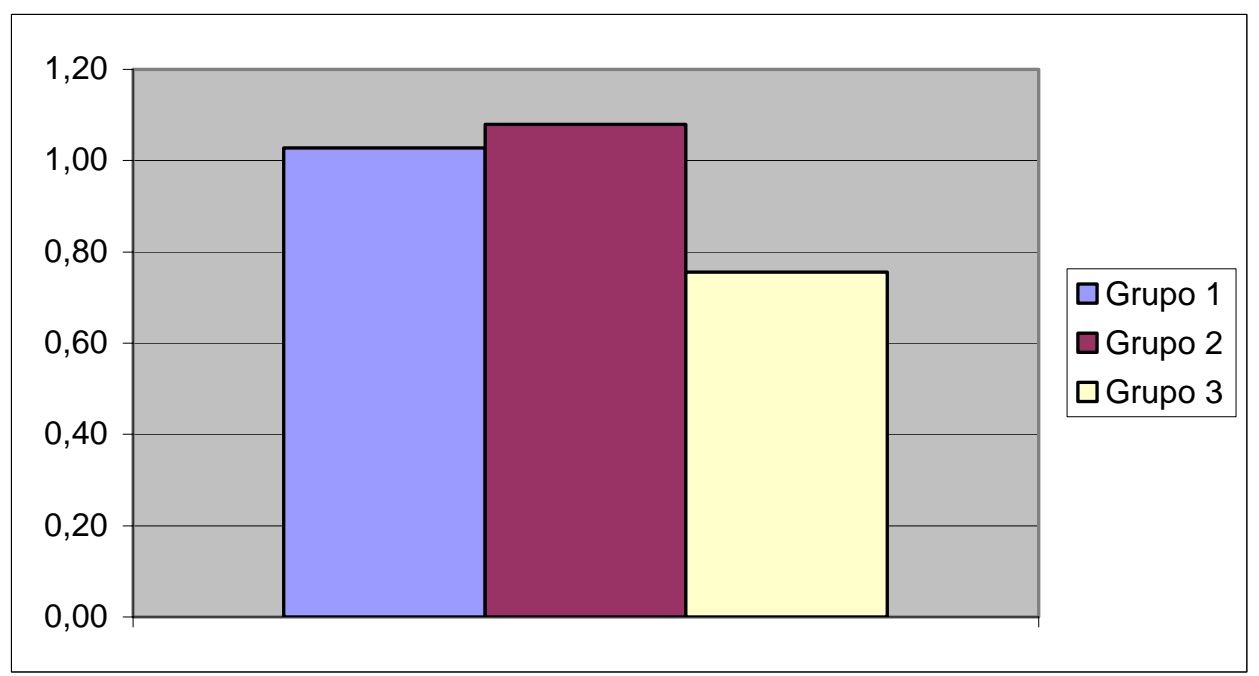

FIGURA 24: Alterações da medida $\overline{6}$-GoMe nos três grupos. 


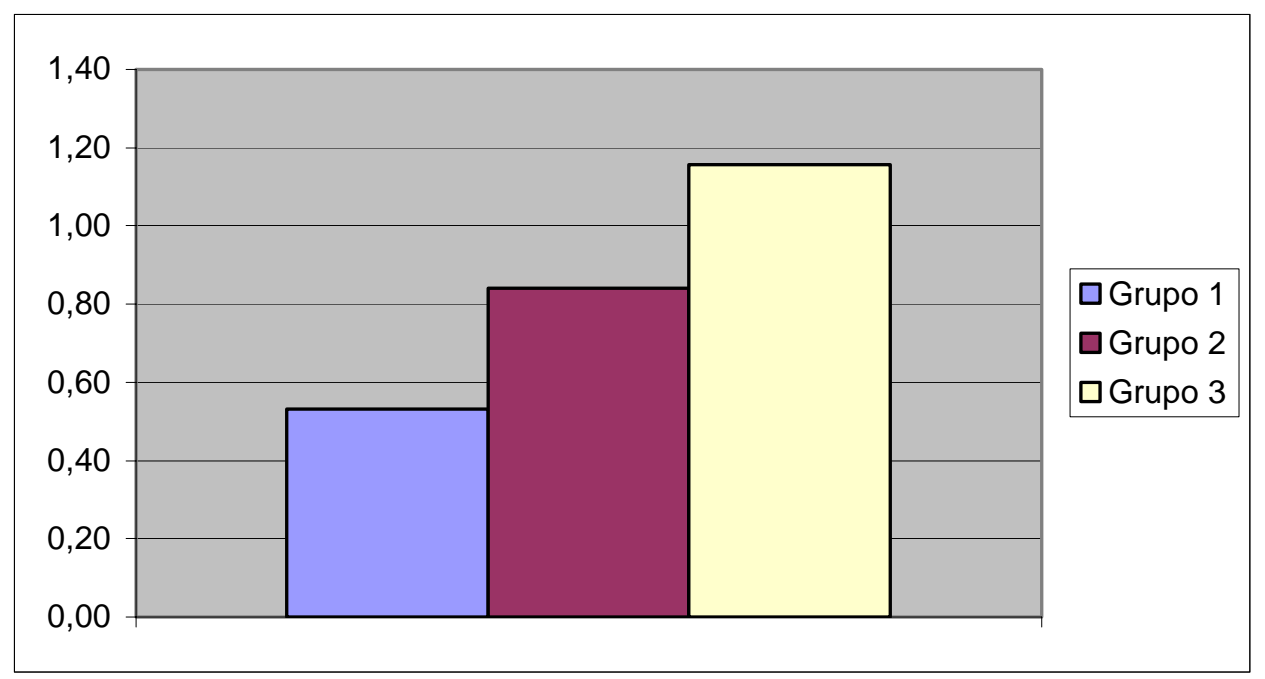

FIGURA 25: Alterações da medida $\overline{1}$-GoMe nos três grupos.

Componentes tegumentares:

Ao avaliar a protrusão do lábio superior, constatou-se que houve resultado estatisticamente significante para os grupos experimentais. Já com o lábio inferior houve resultado não significante, sendo que o mesmo ocorreu para o ângulo nasolabial (ANL).

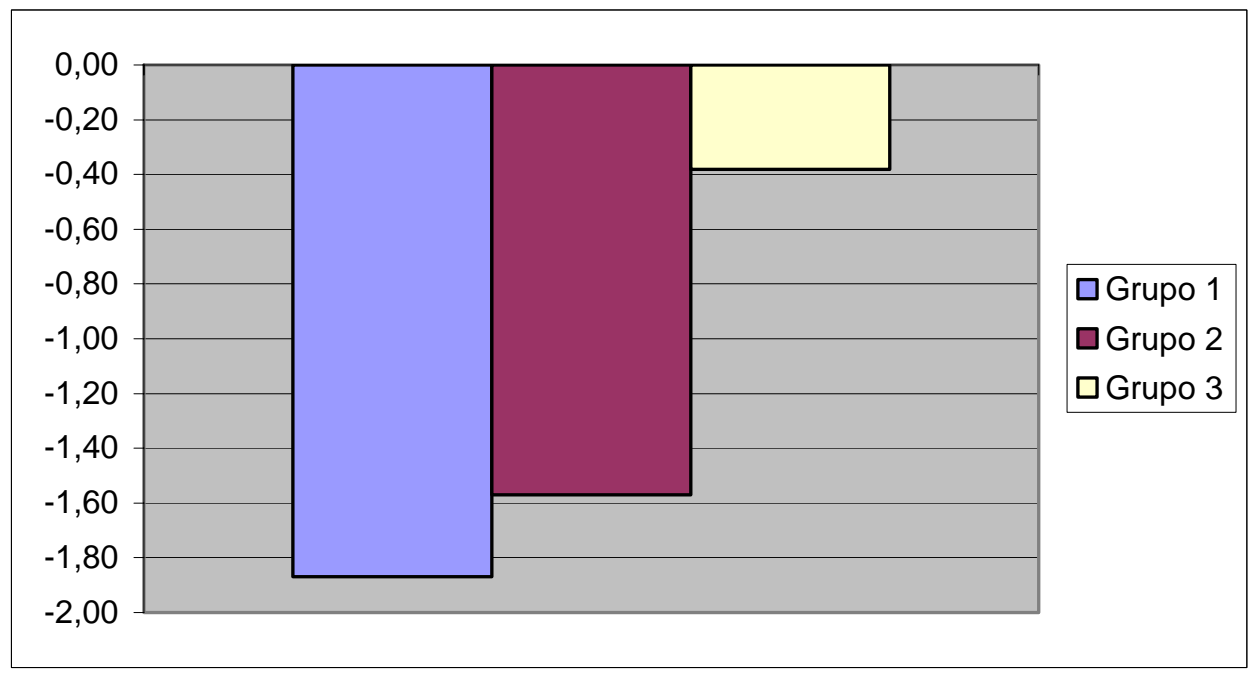

FIGURA 26: Alterações da medida Ls-E nos três grupos. 


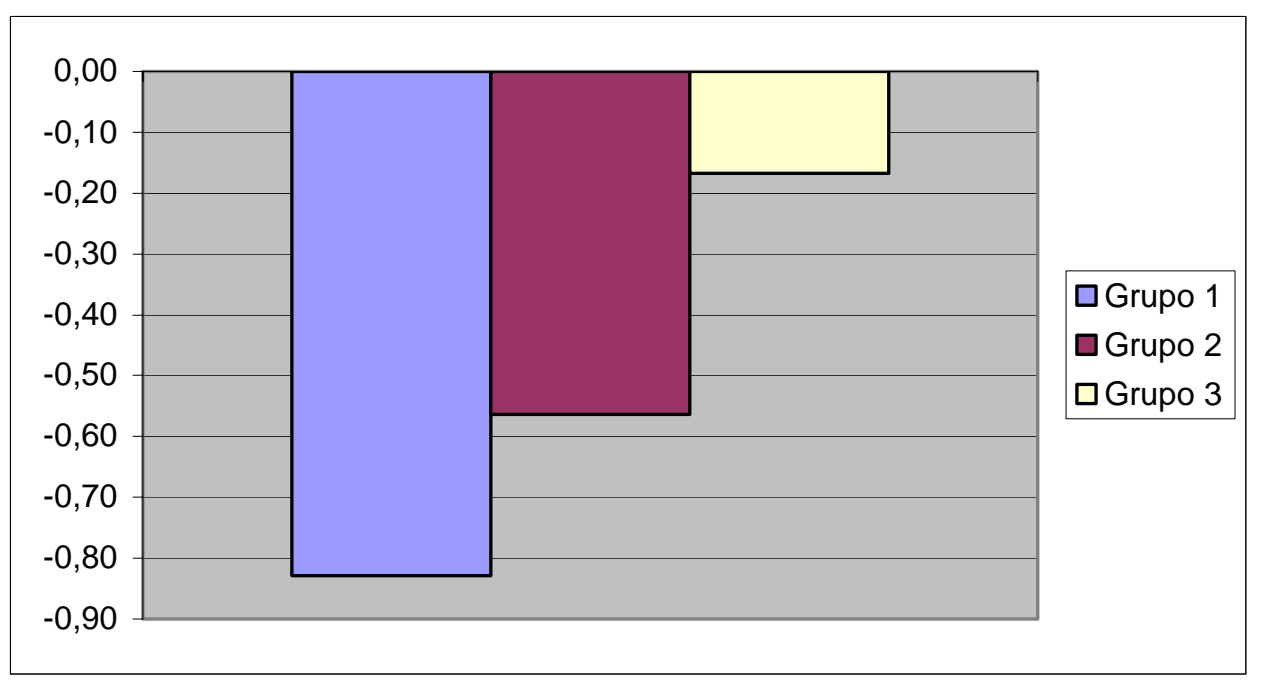

FIGURA 27: Alterações da medida Li-E nos três grupos.

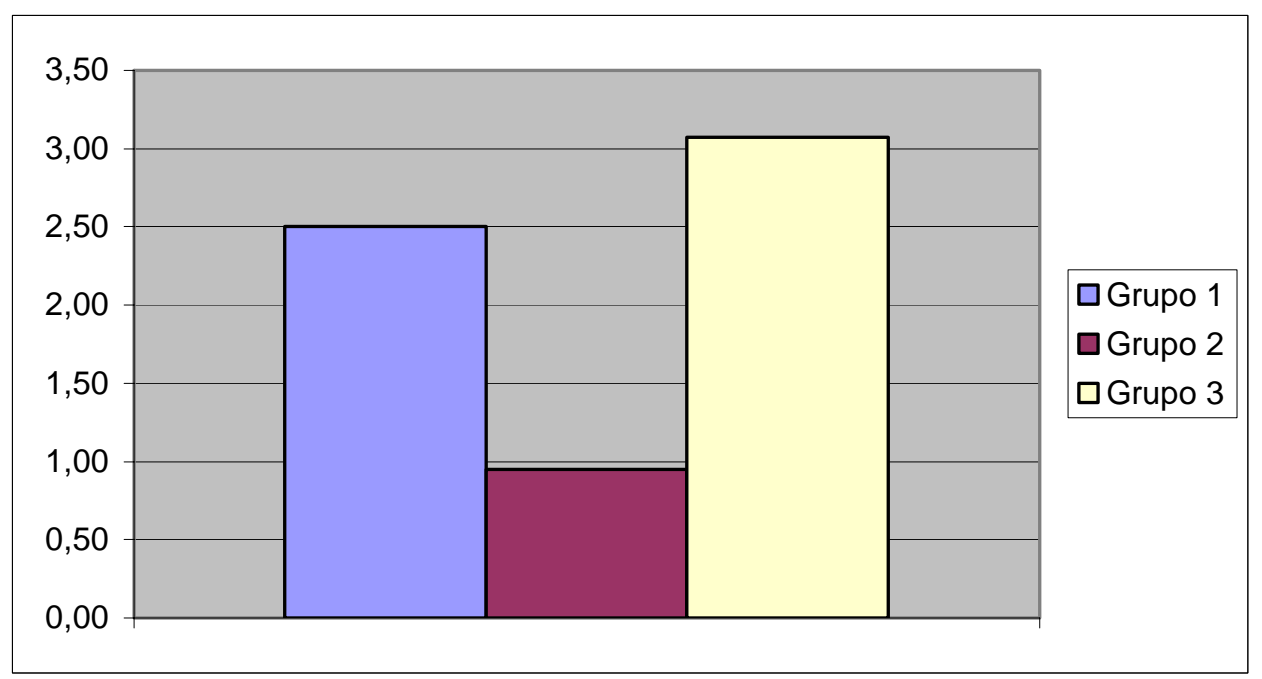

FIGURA 28: Alterações do ângulo ANL nos três grupos. 
Discussão 


\section{DISCUSSÃO}

A discrepância maxilomandibular ânteroposterior classificada como má oclusão de Classe II de Angle ${ }^{11,12}$, apresenta uma ampla área de estudos entre os diversos assuntos ortodônticos ${ }^{3,6,16,50,66,61,78,94,102,119}$, principalmente devido ao grande número de pacientes que apresentam esta má oclusão, alcançando índices de $55 \%$ dos pacientes que procuram tratamento ${ }^{54}$, como relatado anteriormente, além das diversas formas de tratamento que podem ser empregadas, dependendo de diversos fatores. Esta má oclusão não possui morfologia única que defina a estrutura facial, são variadas as relações horizontais e verticais, possuindo em comum, apenas a relação ânteroposterior dos arcos dentários. Esta relação pode variar desde uma retrusão mandibular, uma protrusão maxilar, ou até mesmo uma combinação de fatores, sendo o retrognatismo mandibular considerado como um dos maiores responsáveis por esta má oclusão ${ }^{90}$. A má oclusão de Classe II é considerada esquelética quando temos apenas o envolvimento das bases ósseas maxilares, e é denominada de dentária, quando apresenta puramente alterações dentoalveolares. Podemos observar geralmente, que ocorre a combinação de fatores esqueléticos e dentários. A má oclusão de Classe II pode ainda estar combinada com uma função anormal dos lábios e de alguma forma de obstrução nasal e respiração bucal ${ }^{12}$.

A má oclusão de Classe II pode afetar as características faciais de diferentes maneiras, de acordo com a intensidade do "overjet" (sobressaliência) apresentado, e de sua interação com as estruturas adjacentes de tecidos moles, interferindo profundamente na aparência e na auto-estima do paciente p6,127,128. $^{\text {. }}$

Devido às inúmeras variações dentofaciais que esta má oclusão apresenta, assume-se conseqüentemente que o tratamento deva ser individualizado, sendo que os aparelhos de ancoragem extrabucal estão presentes na maioria dos planos de tratamento desta má oclusão. Os estudos cefalométricos atuais ${ }^{7,95} 5,60$ demonstram que os efeitos esqueléticos derivados de forças intrabucais são muito menos eficazes do que os 
ortodontistas acreditavam no início do século $X X$, e que a força extrabucal derivada dos aparelhos extrabucais são imbatíveis ${ }^{32,45,73,76,82,83,88,101,116}$. Com relação ao efeito obtido de restrição do crescimento anterior da maxila, promovida pelo AEB, há um consenso entre vários autores ${ }^{3,5,35,53,63,64,65,84,88,121}$ de que este fato realmente é observado, sendo portanto extremamente significativo com relação à sua ação na má oclusão de Classe II.

Devido à grande utilização clínica dos aparelhos extrabucais, avaliouse as alterações e as contribuições promovidas visando a correção da má oclusão de Classe II, $1^{\text {a }}$ divisão por dois diferentes aparelhos, o AEB/IHG e o AEB Conjugado, ambos de tração occipital, comparando com um grupo controle que apresenta também a mesma má oclusão.

A importância em utilizar-se um grupo controle em pesquisas é enorme, na tentativa de comparar os efeitos de diferentes aparelhos, uma vez que a simples comparação entre pacientes tratados não distingue entre as alterações provocadas unicamente pelo crescimento e/ou tratamento. Há alterações que ocorrem não devido à utilização das terapias, mas simplesmente pelo próprio crescimento do paciente.

A escassez de grupos controles, compostos por pacientes com más oclusões de Classe II, está em relação direta com a dificuldade em se realizar acompanhamentos periódicos destes pacientes por tempo prolongado, pois é considerado antiético não tratá-los. Portanto para a realização deste estudo, utilizamos um grupo controle já existente na Disciplina de Ortodontia da FOB/USP.

No ímpeto de discutir os resultados dente trabalho, e para melhor compreensão e visualização da metodologia empregada e dos resultados obtidos, dividiu-se este capítulo em três tópicos, cada um com suas subdivisões, sendo eles:

6.1 Erro do método;

6.2 Interpretação e discussão dos resultados; 


\subsection{Erro do método}

O estudo radiográfico cefalométrico, apresenta-se como um inestimável recurso para o diagnóstico, planejamento e acompanhamento ortodôntico. No entanto, para a utilização destas radiografias em pesquisas científicas, tornase necessária a determinação do erro proveniente dos procedimentos envolvidos no traçado cefalométrico e na demarcação e digitalização dos pontos.

Os erros metodológicos são classificados em dois tipos: erro sistemático e casual. Para determiná-los HOUSTON ${ }^{69}$ sugeriu a duplicação dos cefalogramas em intervalos de tempo diferentes. Assim, de acordo com BAUMRIND; FRANTZ ${ }^{18}$ foram selecionadas ao acaso 30 telerradiografias provenientes dos 3 grupos estudados. Todas as radiografias foram traçadas e digitalizadas novamente por um único operador num intervalo de tempo de 4 semanas do traçado inicial, segundo recomendações de MIDTGARD; BJORK; LINDER-ARONSON ${ }^{93}$.

Para a verificação da significância estatística do erro sistemático utilizou-se o teste $\mathrm{t}$ de Student ao nível de 1\% e 5\%, e do erro casual a fórmula de DAHLBERG ${ }^{41}$.

Com relação ao erro sistemático, apenas duas variáveis, das vinte e três estudadas, apresentaram-se com este erro.

Diante destas observações pode-se considerar que os resultados do erro metodológico demonstraram uma reprodutibilidade adequada dos cefalogramas realizados pelo examinador, uma vez que a precisão das mensurações empregadas nesta pesquisa encontrou-se dentro dos parâmetros aceitáveis não comprometendo os resultados e conclusões deste estudo. 
6.2 Interpretação e discussão dos resultados

Para interpretar e discutir os resultados constatados, vamos nos basear nas alterações dentoesqueléticas e tegumentares encontradas na comparação entre os grupos experimentais e controle.

De acordo com a proposição do estudo, os diferentes efeitos foram divididos em tópicos e serão discutidos da seguinte forma:

6.2.1 Alterações esqueléticas:

6.2.1.1 Componente maxilar;

6.2.1.2 Componente mandibular;

6.2.1.3 Relação maxilomandibular;

6.2.1.4 Relação vertical.

6.2.2 Componente dentoalveolar.

6.2.3 Componente tegumentar.

6.2.1 Alterações esqueléticas:

6.2.1.1 Componente maxilar:

Há autores ${ }^{23,29,36,66}$ que não consideram a maxila como a principal responsável pelo desenvolvimento da má oclusão de Classe II, $1^{a}$ divisão, uma vez que esta se encontra bem posicionada ou até mesmo retruída em relação à base do crânio ${ }^{9,66}$. Mas deve-se observar também que outros autores ${ }^{8,9,14,43,51,66,106,111,115,128}$ encontraram a maxila protruída em relação à base do crânio.

Espera-se que os aparelhos promovam alterações no comprimento maxilar justamente por saber que o comprimento maxilar aumenta 
gradativamente com a idade, dos 6 aos 18 anos cerca de um grau ou um milímetro, em ambos os gêneros ${ }^{87,91}$.

Nesta pesquisa, os aparelhos utilizados mostraram uma restrição na protrusão e no crescimento maxilar. Alguns autores ${ }^{91,126}$ afirmam que o ponto A (referência maxilar) está sujeito às alterações nas posições dos incisivos superiores e pode mascarar a interpretação do posicionamento anteroposterior da maxila.

As grandezas cefalométricas SNA, Co-A e FHP-A, foram utilizadas para avaliação das alterações ocorridas no componente maxilar, sendo que os resultados demonstraram diferenças estatísticas significantes entre os grupos, sendo que em ambos os grupos experimentais a maxila mostrou restrição na sua protrusão e no seu comprimento efetivo, concordando portanto com vários estudos anteriormente elaborados ${ }^{3}$ 7,17,35 53,63,64 65,84,88 $121,124,125$

O ângulo SNA avaliado nos três grupos mostra que houve uma restrição no crescimento para anterior da maxila, pois este ângulo diminuiu nos três grupos avaliados, com menor diminuição no grupo controle, como observado em vários trabalhos ${ }^{5,35,64}$ e no gráfico abaixo, porém este resultado não foi estatisticamente significante.

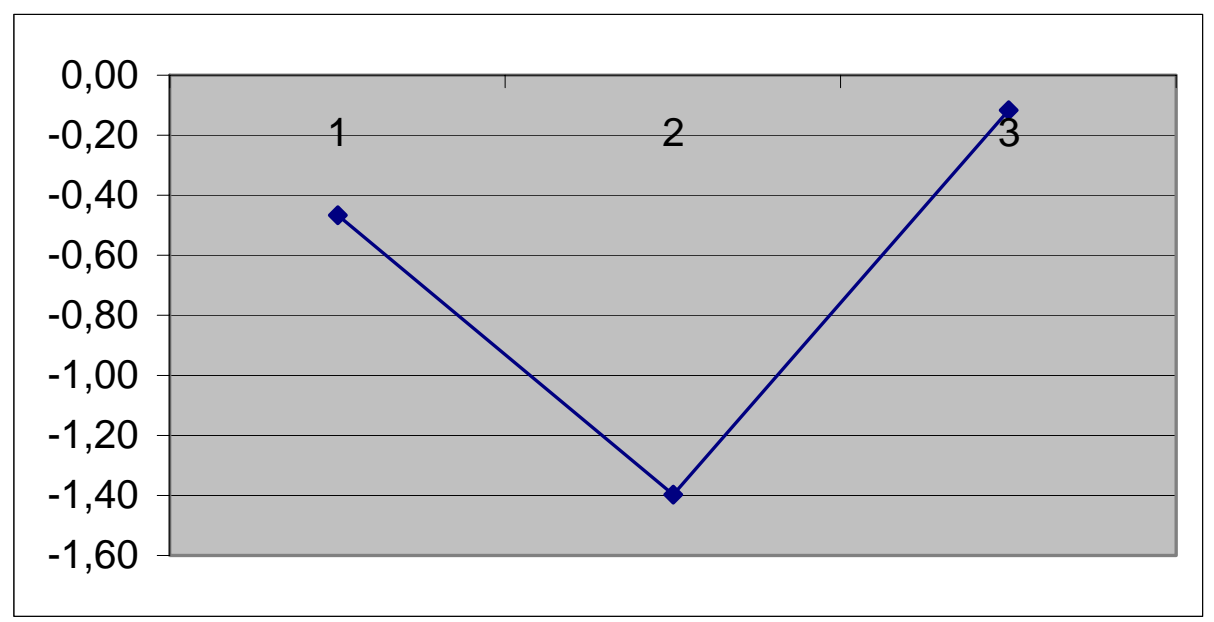


FIGURA 29: Alterações do ângulo SNA nos três grupos.

Em relação a variável FHp-A, também no intuito de investigar a posição da maxila em relação a base do crânio, observa-se que os valores apresentados mostraram diferença estatisticamente significante ao analisar os grupos experimentais com relação ao grupo controle, denotando portanto uma restrição na protrusão maxilar nos grupos experimentais, conforme observado em estudos anteriores supra descritos ${ }^{5,35,64}$.

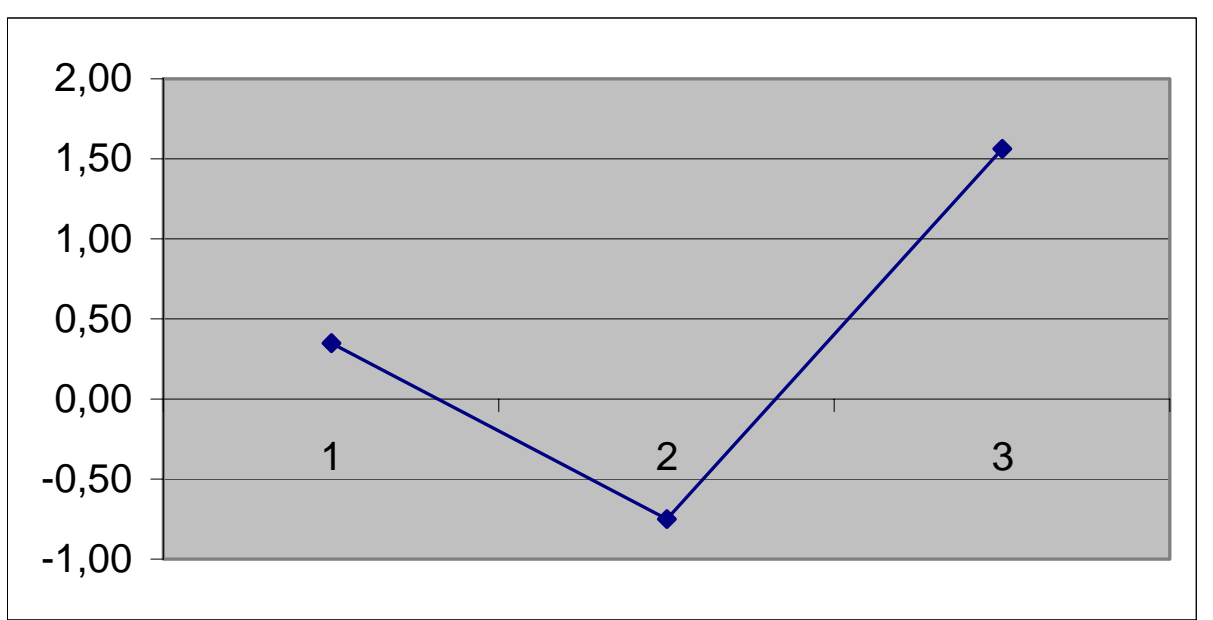

FIGURA 30: Alterações nos três grupos da grandeza FHP-A.

Em relação ao comprimento efetivo da maxila, avaliada pela medida linear Co-A, notou-se um aumento para todos os grupos, com diferença estatisticamente significante entre os grupos 1 e 3; 2 e 3 (tabelas 8, 9, 10 e 11). Este resultado confirma a restrição do crescimento maxilar nos grupos tratados, uma vez que os valores destes grupos foram menores que o grupo controle. 


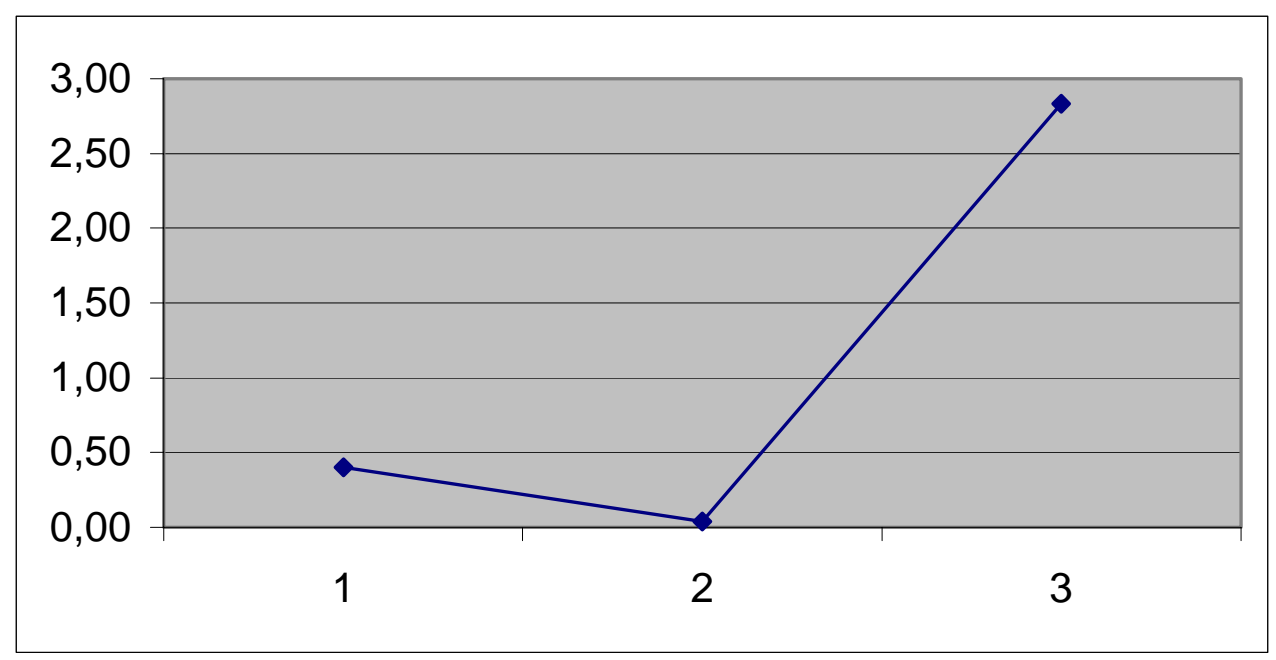

FIGURA 31: Grandeza Co-A para os três grupos.

Sumariamente, pode-se concluir que os aparelhos utilizados nos grupos experimentais promoveram restrição da maxila em relação ao deslocamento ântero-posterior, e em seu comprimento efetivo.

\subsubsection{Componente Mandibular:}

A mandíbula exerce grande influência na caracterização da má oclusão de Classe II, apresentando-se com deficiência no seu desenvolvimento para anterior, ou mostrando-se retruída em relação à maxila e à outros componentes cranianos $^{12,26,34,51,74,86,96,129}$. Já outros autores ${ }^{10,56,83,111,112,113}$ discordam destes, afirmando que na Classe $I I, 1^{\mathrm{a}}$ divisão, a mandíbula apresenta-se bem posicionada.

Avaliou-se neste estudo a posição da mandíbula em relação à base do crânio, por meio da grandeza SNB, e o comprimento efetivo mandibular, por meio da grandeza Co-Gn.

O crescimento mandibular normalmente ocorre no sentido pósterosuperior deslocando a mandíbula no sentido horário. No entanto, na má olcusão de Classe II, $1^{\text {a }}$ divisão a mandíbula pode não crescer ou não deslocar- 
se adequadamente. Portanto objetiva-se estimular e/ou liberar o desenvolvimento mandibular ao interceptarmos a má oclusão de Classe II $1^{\text {a }}$ divisão com aparelhos ortopédicos, conseqüentemente esperamos obter valores maiores do SNB nos grupos experimentais. Foi o que ocorreu, sendo que o SNB mostrou-se maior no grupo tratado com o aparelho extrabucal conjugado, muito provavelmente devido à cobertura de acrílico que este aparelho possui na face oclusal dos dentes superiores posteriores, o que contribui para o desenvolvimento mandibular, seguido pelo segundo grupo experimental tratado com o aparelho de tração occipital, porém com resultado não significante em relação ao grupo controle.

A maioria dos pesquisadores ${ }^{17,63,64,65,84,88,121,125}$ corroboram com os resultados obtidos ao analisarem o aparelho AEB conjugado evidenciando a medida SNB. Apenas em um trabalho ${ }^{35}$ observou-se discordância com relação ao ângulo SNB, apresentando diminuição nos grupos experimentais, acreditase portanto que possa ser devido ao deslocamento da mandíbula no sentido horário.

Quando se analisa as alterações mandibulares expressas pela grandeza SNB no grupo experimental tratado com o AEB/IHG, observa-se um aumento deste valor, comparado com o grupo controle, apesar de estatisticamente não significante, portanto a correção da má oclusão de Classe II $1^{\text {a }}$ divisão com este tipo de aparelho não proporcionou o deslocamento para anterior da mandíbula, concordando com outros trabalhos ${ }^{105,126}$. 


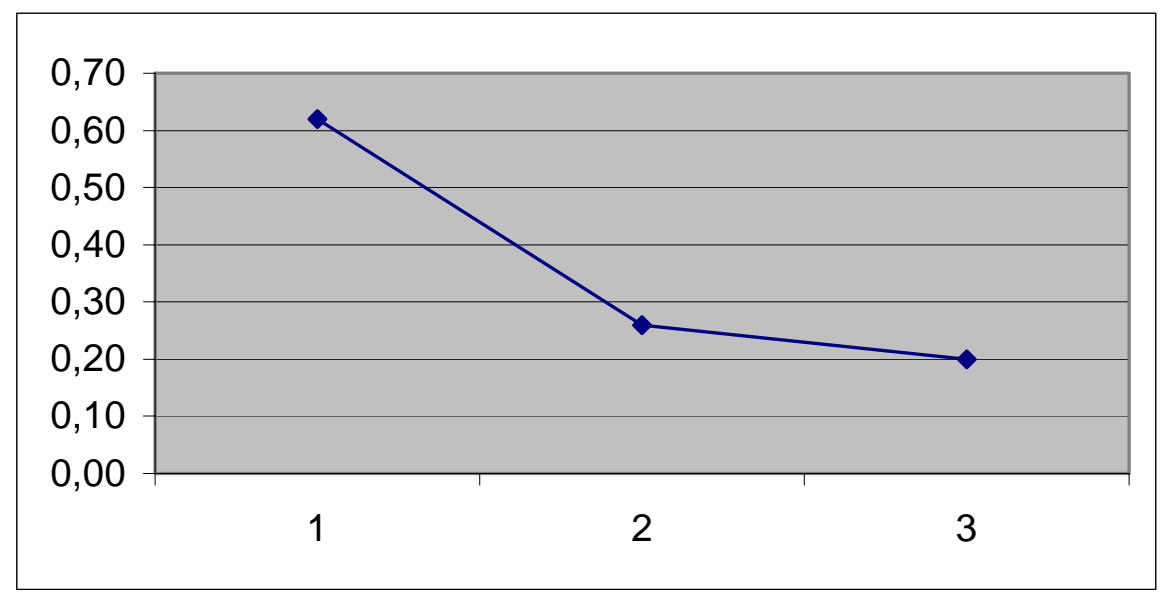

FIGURA 32: Alterações do ângulo SNB nos três grupos.

A dimensão mandibular representada pela grandeza Co-Gn aumentou nos três grupos, apresentando diferença estatisticamente significante somente entre o grupo tratado com o AEB conjugado em relação ao grupo controle. Houve um maior aumento desta medida no grupo tratado com o aparelho extrabucal conjugado, seguido pelo outro grupo experimental. Há uma unanimidade com relação ao aumento do comprimento mandibular nos grupos tratados com aparelhos funcionais para a correção da má oclusão de Classe II, $1^{\mathrm{a}}$ divisão, entre os autores pesquisados ${ }^{7,17,55,65,95}$.

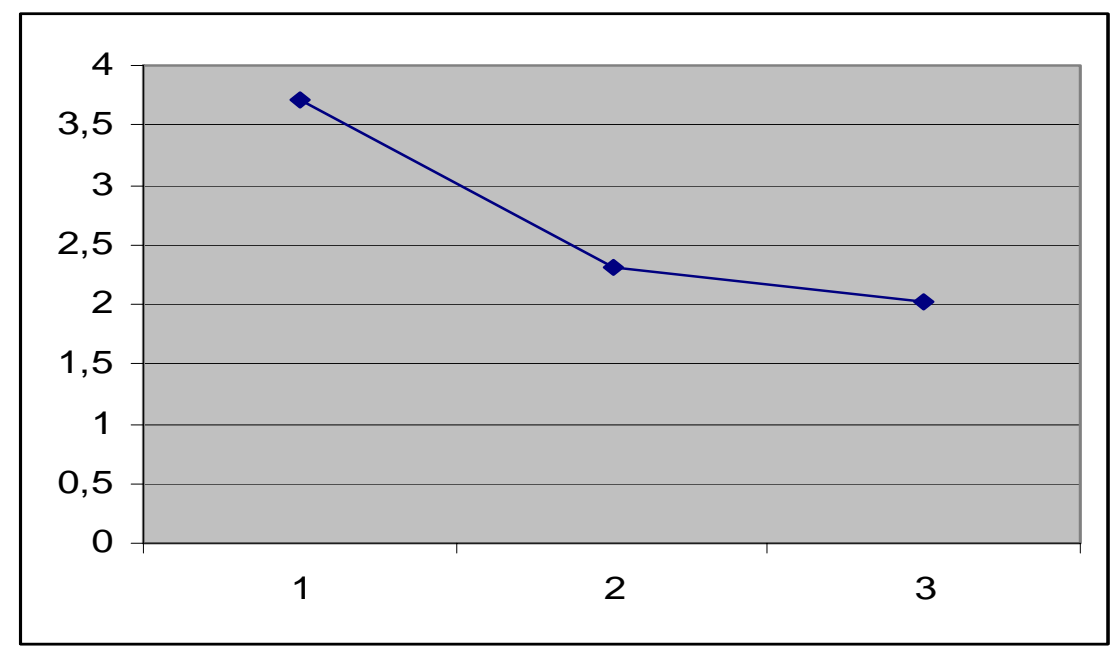

FIGURA 33: Alterações da medida Co-Gn nos três grupos. 


\subsubsection{Relação maxilomandibular:}

A discrepância na relação maxilomandibular inicialmente apresentada diminuiu consideravelmente após o tratamento, devido diretamente às alterações ocorridas nos componentes maxilar e mandibular.

Analisou-se a relação maxilomandibular por meio da variável ANB, sendo que houve diminuição deste ângulo para os três grupos estudados, observando uma maior diminuição no grupo tratado com o aparelho AEB/IHG, seguido do grupo tratado com o aparelho AEB conjugado, sendo que houve alterações estatisticamente significantes ao comparar os grupos AEB/IHG e o controle.

O ajuste sagital entre as bases ósseas ocorre normalmente pelo crescimento diferencial entre a maxila e a mandíbula. Neste período observase uma diminuição do ângulo ANB e uma tendência de melhora da convexidade facial, desde que os vetores de crescimento se processem em equilíbrio na direção ântero-inferior.

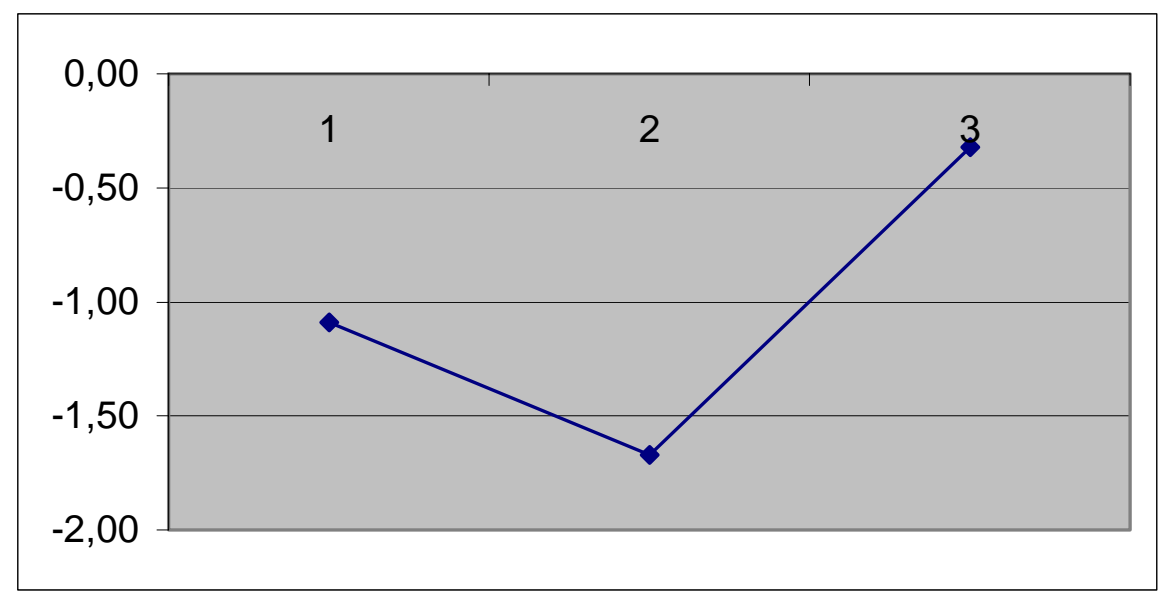

FIGURA 34: Alterações do ângulo ANB nos três grupos.

Esta diminuição da discrepância na relação maxilomandibular observada por meio da diminuição do ângulo ANB é relatada por outros autores $^{3,4,5,17,35,53,63,64,65,84,88,106,121,125}$. 


\subsubsection{Relação vertical:}

O comportamento das bases ósseas no sentido vertical sem dúvida é uma das características mais marcante na má oclusão de Classe II, $1^{\text {a }}$ divisão. Utilizou-se para a verificação das alterações, nos três gupos, dos componentes verticais da face, as variáveis: AFAI, SN.GoMe, SN.PP, FRANK.Plo, PP.GoMe, FRANK.GoMe, Ar.GoMe.

Comumente nesta má oclusão observa-se um excesso vertical de maxila, uma rotação horária da mandíbula e concomitantemente um aumento da $\mathrm{AFAl}^{14,34,44,66,74,82,90,97,116,128,129}$. Esta morfologia agrava a discrepância ântero-posterior. Assim, torna-se imprescindível o conhecimento dos efeitos suscitados por distintos aparelhos na correção desta entidade, buscando um controle vertical.

Todas as variáveis eleitas para o estudo das alterações verticais não mostraram diferença estatisticamente significante, concordando com diversos autores $2,35,63,64,67,87,88,125$ que afirmam que os aparelhos ortopédicos não causam alterações no sentido vertical, desde que bem indicados e controlados durante as ativações.

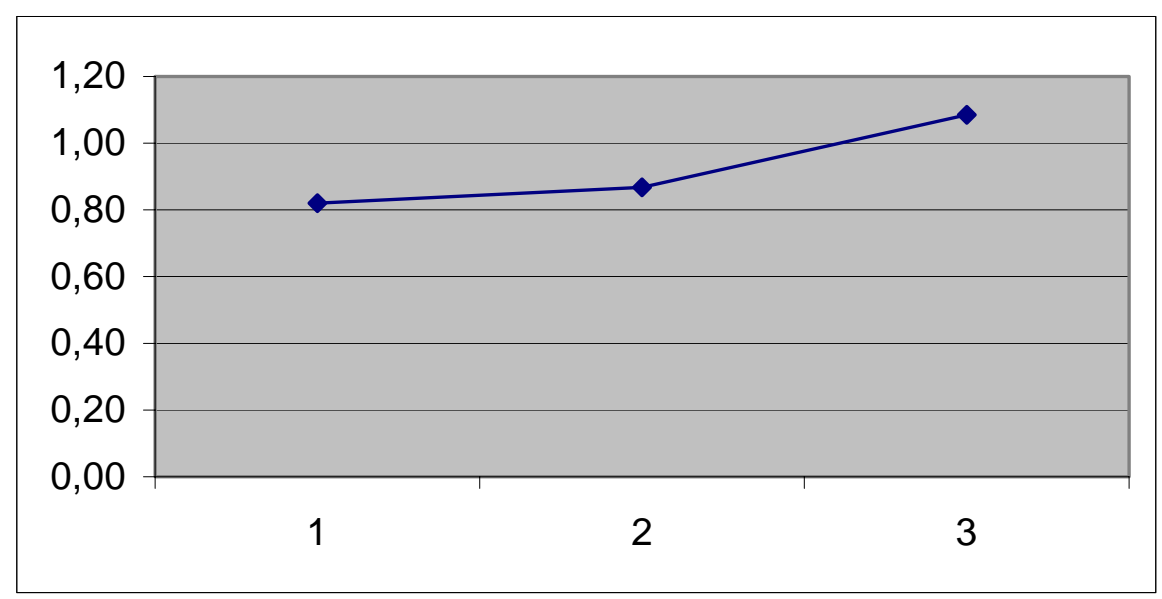

FIGURA 35: Alterações da AFAI nos três grupos. 
A AFAl mostrou um menor aumento nos grupos tratados, porém sem diferença estatística, concordando com alguns trabalhos anteriores $^{2,35,63,64,67,87,88,125}$.

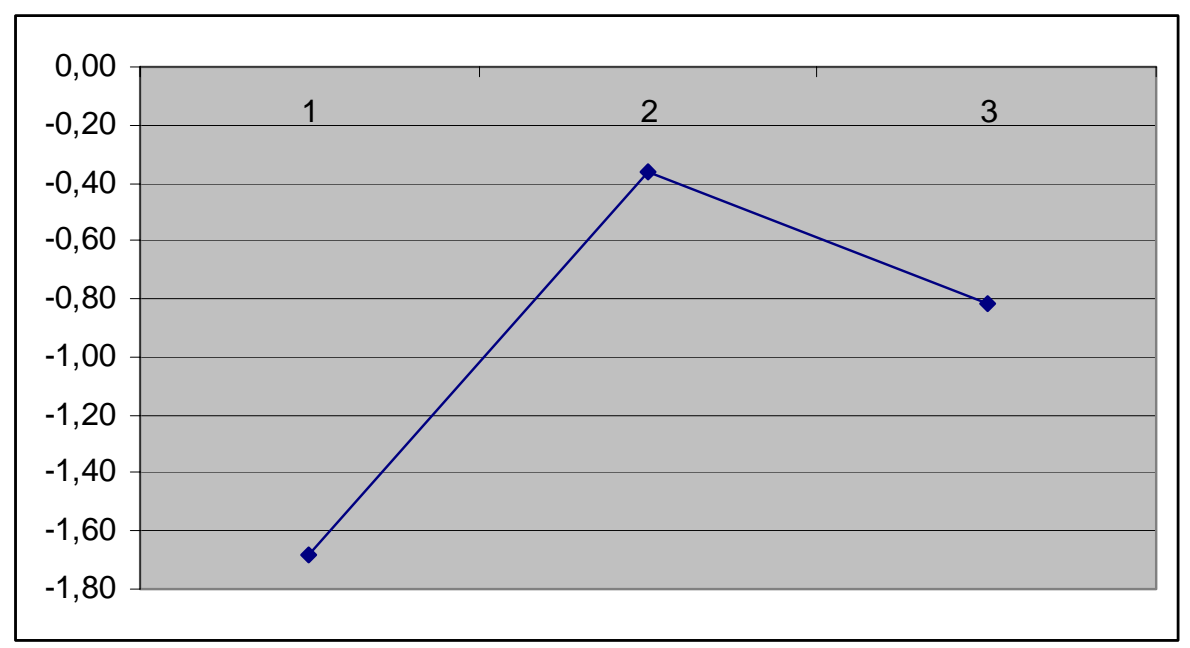

FIGURA 36: Alterações do ângulo SN.GoMe nos três grupos.

O ângulo SN.GoMe mostrou-se com uma maior diminuição no grupo tratado com o aparelho extrabucal conjugado, porém também com valores estatísticos insignificantes.

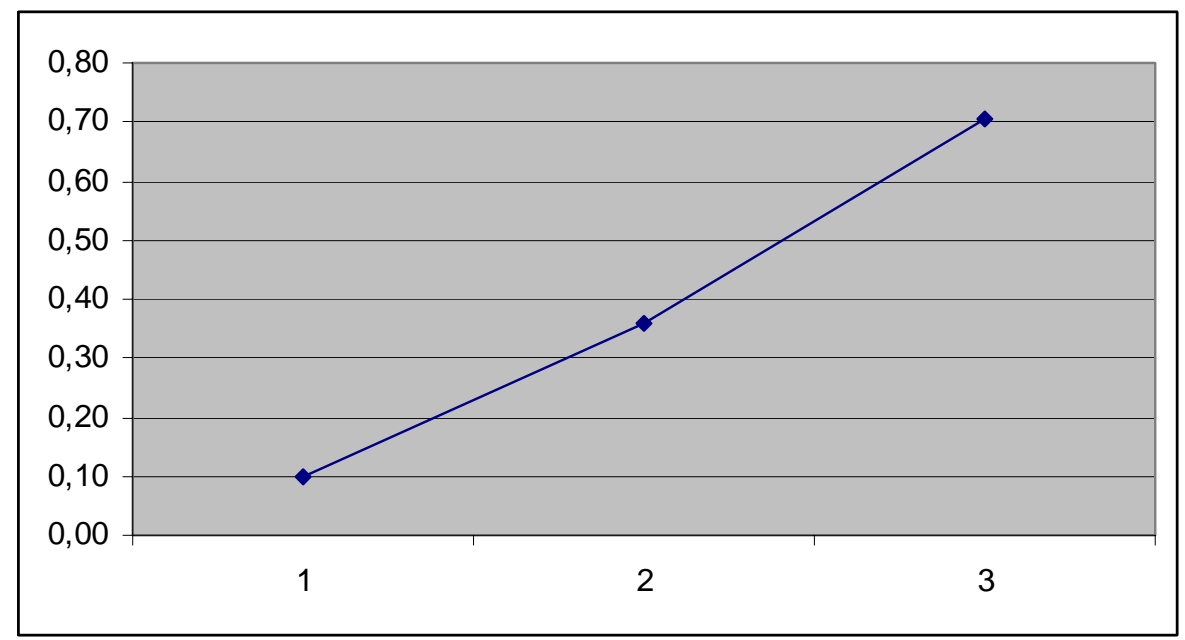

FIGURA 37: Alterações do ângulo SN.PP nos três grupos. 
O ângulo SN.PP mostrou um menor aumento no grupo experimental tratado com o aparelho extrabucal conjugado, seguido pelo outro grupo experimental, mas também com resultado estatístico não significante.

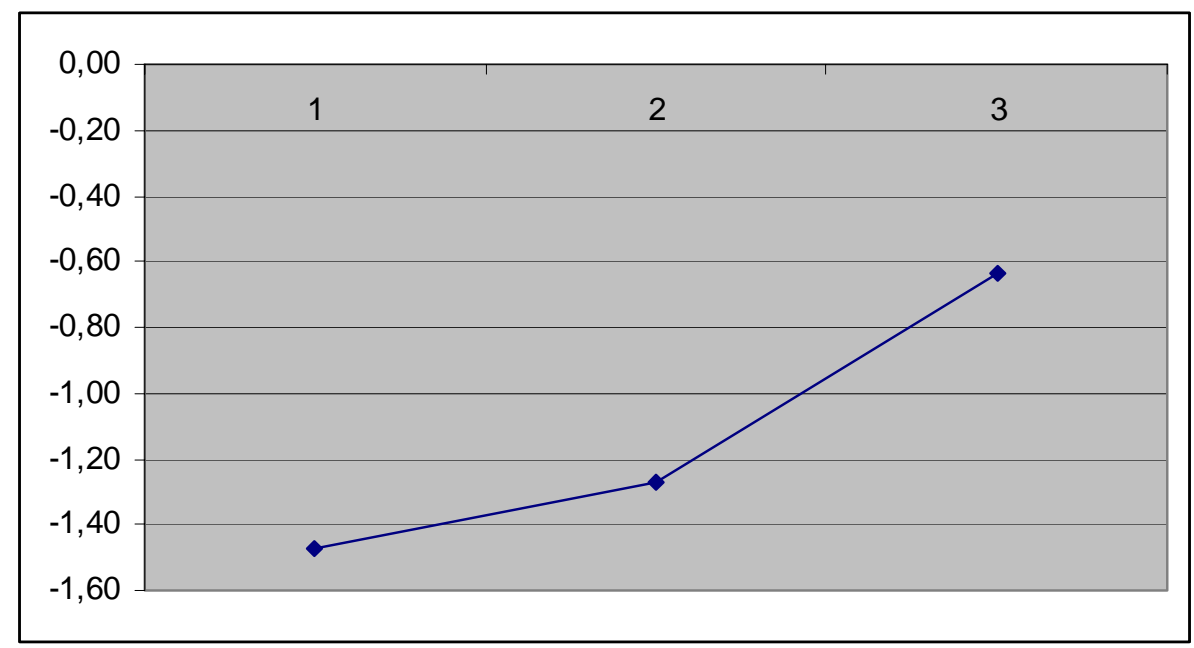

FIGURA 38: Alterações do ângulo FRANK.Plo nos três grupos.

Apesar do resultado não significante, o grupo tratado com o aparelho extrabucal conjugado apresentou uma maior restrição do ângulo FRANK.Plo.

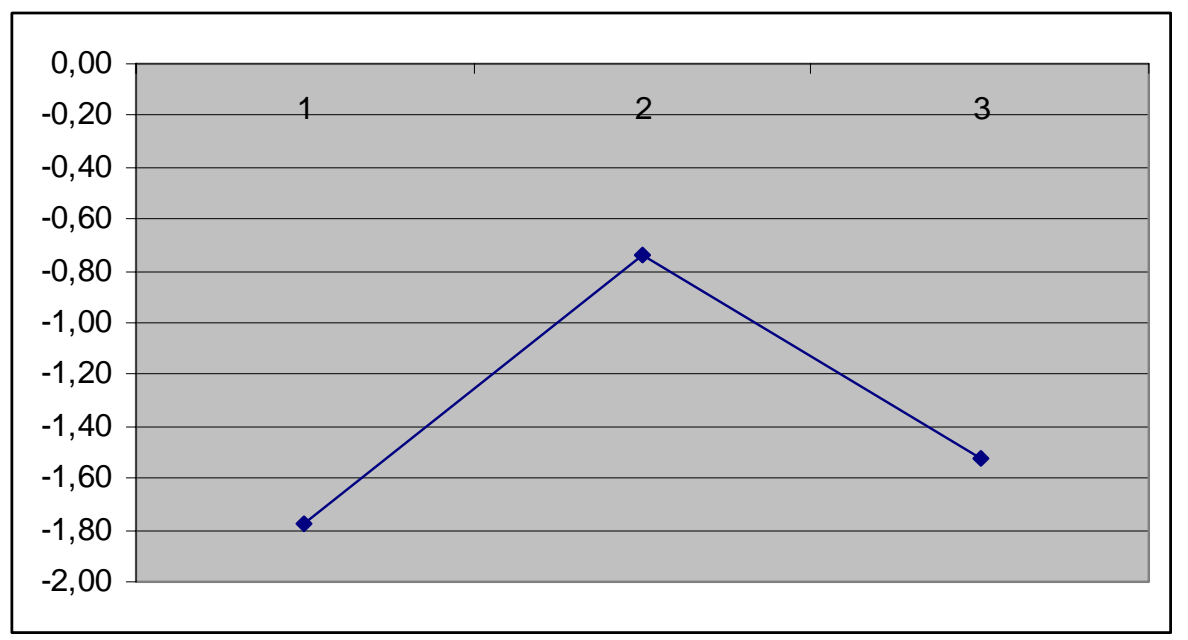

FIGURA 39: Alterações do ângulo PP.GoMe nos três grupos. 
O grupo experimental tratado com o aparelho extrabucal de tração occipital apresentou uma menor restrição do ângulo PP.GoMe. Já o outro grupo experimental apresentou uma maior restrição nesta grandeza.

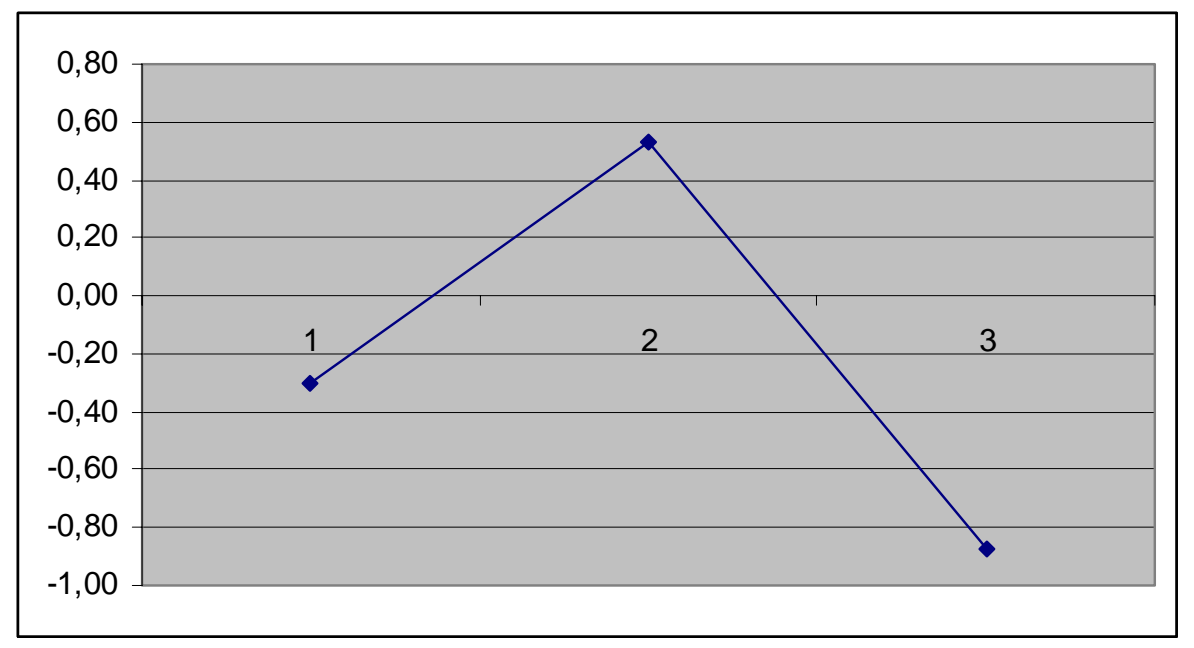

FIGURA 40: Alterações na grandeza FRNAK.GoMe nos três grupos.

Com relação à grandeza FRANK.GoMe, apesar de apresentar resultados não significantes, o grupo experimental tratado com o aparelho extrabucal de tração occipital apresentou um aumento, sendo que a maior restrição deste ângulo deu-se no grupo controle.

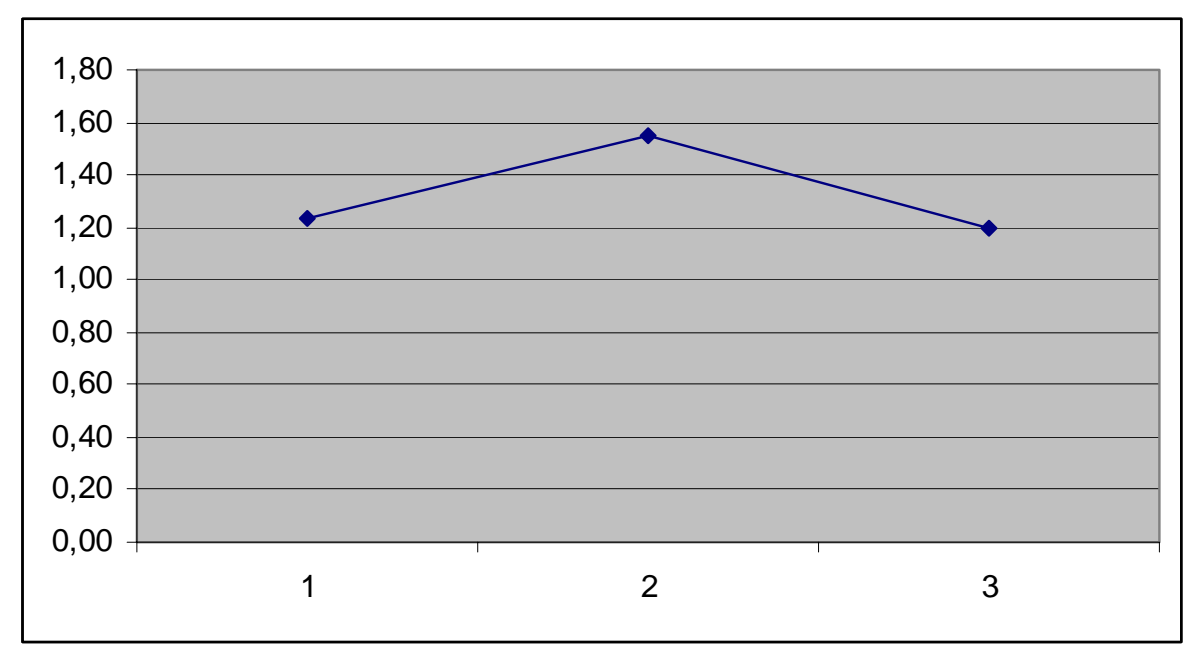

FIGURA 41: Alterações do ângulo Ar.GoMe nos três grupos. 
O ângulo Ar.GoMe apresentou um menor aumento no grupo tratado com o aparelho extrabucal de tração occipital, seguido pelo outro grupo experimental, apesar de estatisticamente não significante.

\subsubsection{Componente dentoalveolar:}

Os aparelhos promovem a correção da má oclusão de Classe II, $1^{a}$ divisão por meio de movimentações dentárias e alterações esqueléticas. Neste tópico as alterações dentárias serão analisadas.

Avaliou-se os dentes superiores por meio das grandezas cefalométricas: 1.NA, FHP-DISTAL $\underline{6}$, FHP-ÁPICE $\underline{6}, \underline{6}-P P, \underline{1}-P P$.

Como característica patognomônica da má oclusão de Classe II, $1^{a}$ divisão os incisivos superiores apresentam-se vestibularizados e protruídos na base óssea ${ }^{12,23,29,36,44,51,75,76,82,83,90,100,112,116,128}$.

Os resultados desta pesquisa evidenciaram que os aparelhos avaliados promoveram alterações significantes no posicionamento dos incisivos superiores. O grupo tratado com o aparelho AEB conjugado mostrou uma inclinação para lingual dos incisivos superiores estatisticamente significante, quando comparados com o grupo tratado com o aparelho AEB/IHG e com o grupo controle, provavelmente devido ao uso do arco vestibular daquele aparelho. Já no grupo tratado com o aparelho AEB/IHG obteve-se uma diferença estatisticamente não significante, quando comparado com o grupo controle. Ao compulsar a literatura pertinente, percebeu-se que a maioria dos autores $^{3,5,35,63,64,72} 84,88,112$ relataram uma lingualização dos incisivos superiores no grupo tratado com o aparelho AEB conjugado, devido principalmente às características deste aparelho.

Justificando finalmente, a grande diferença no valor obtido na inclinação dos incisivos superiores nos pacientes tratados com o aparelho AEB conjugado deve-se principalmente ao arco vestibular, sendo que este tangencia 
ativamente a superfície vestibular destes dentes. Porém essa verticalização dos incisivos superiores é favorável nos casos de um trespasse horizontal acentuado com os incisivos inclinados para vestibular.

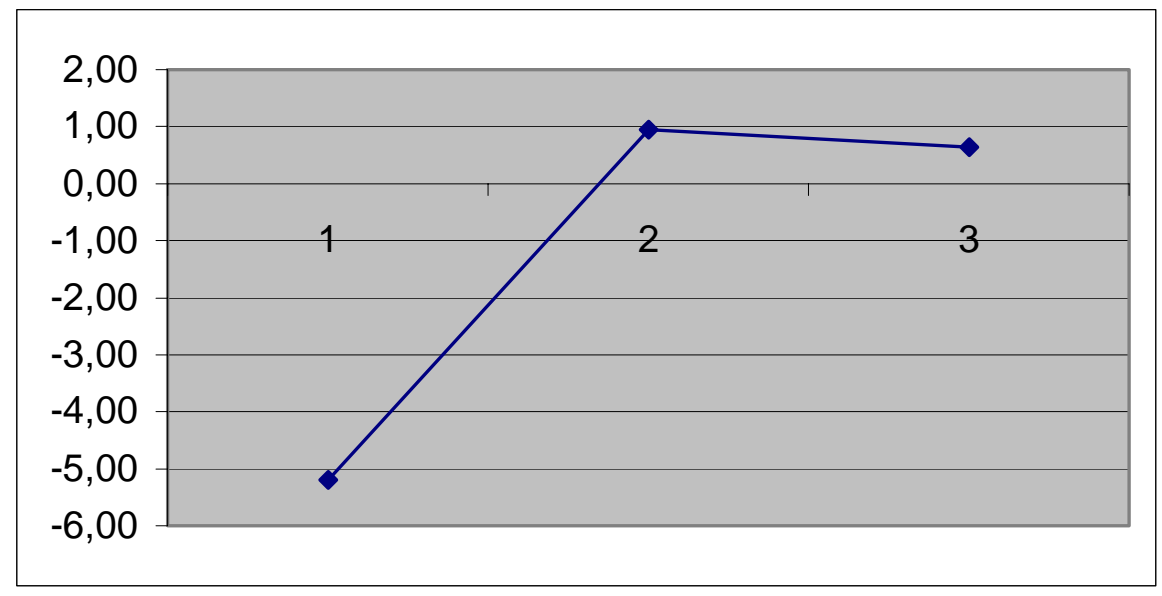

FIGURA 42: Alterações do ângulo 1..NA nos três grupos.

Com relação à extrusão dos incisivos superiores, estudada pela grandeza 1-PP, obteve-se resultados estatisticamente não significantes para os três grupos, com valores muito próximos, significando portanto que estes dentes mantiveram-se estáveis nas suas posições no sentido vertical, como mostra a maioria dos estudos anteriores ${ }^{63,64,88,112}$.

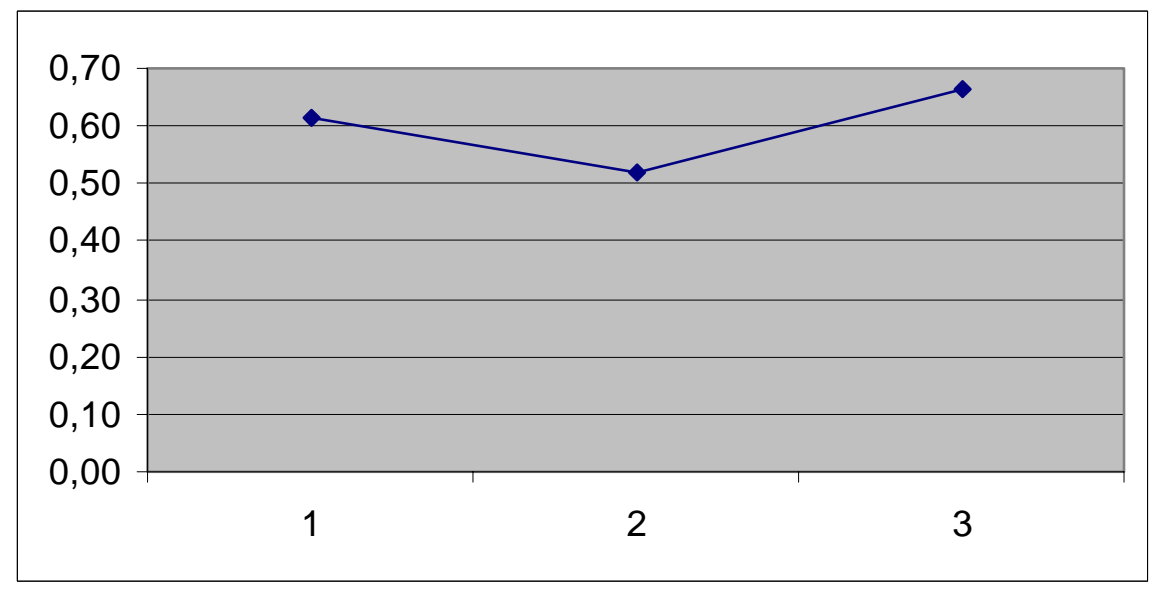


FIGURA 43: Alterações da grandeza 1-PP nos três grupos.

A grandeza linear $\underline{6}-\mathrm{PP}$, utilizada para estudar o posicionamento dos molares superiores no sentido vertical, demonstrou similaridade nos três grupos, apresentando-se estatisticamente não significante, sendo que ocorreu um menor aumento nos grupos tratados, principalmente no grupo experimental tratado com o aparelho AEB/IHG, sendo porém, estatisticamente insignificante. A extrusão excessiva dos molares superiores é geralmente indesejada no tratamento da má oclusão de Classe II, $1^{\text {a }}$ divisão, uma vez que poderia girar a mandíbula no sentido horário e agravar a má oclusão.

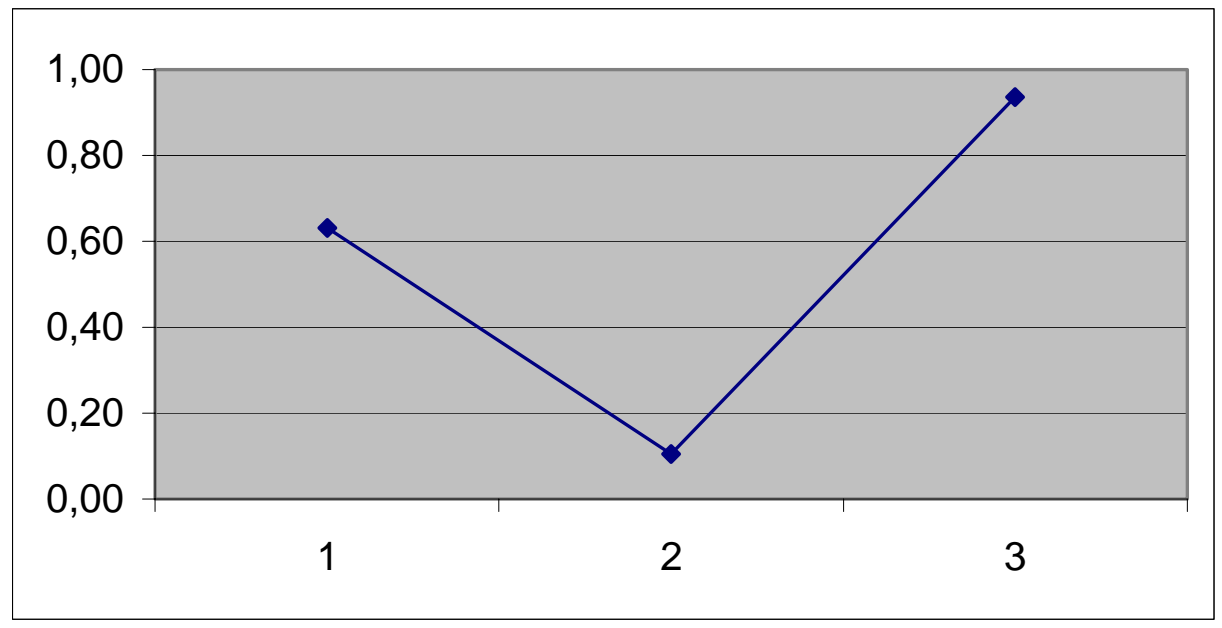

FIGURA 44: Alterações da medida $\underline{6}$-PP para os três grupos.

Em relação à posição dos primeiros molares superiores no sentido ântero-posterior avaliada pelas grandezas FHP-ÁPICE $\underline{6}$ e FHP-DISTAL $\underline{6}$ verificou-se uma distalização estatisticamente significante destes dentes nos grupos tratados, tanto de coroa quanto de raiz, caracterizando portanto uma movimentação de corpo, principalmente no grupo tratado com o aparelho AEB/IHG. Já no grupo sem tratamento houve uma mesialização destes dentes. Apresentou-se apenas diferença significante quando comparados os grupos AEB conjugado com o grupo controle e AEB/IHG com o grupo controle, sendo que não houve diferença estatisticamente significante entre os grupos experimentais, corroborando com estudos anteriores ${ }^{36,53,63,84,88,124,125}$. 


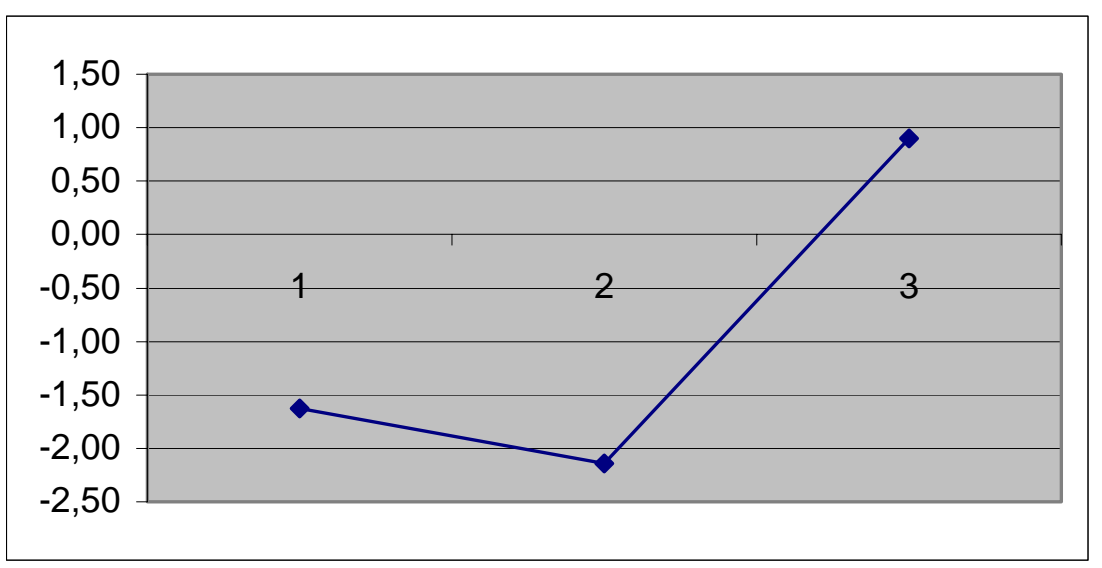

FIGURA 45: Alterações da grandeza FHP-ÁPICE $\underline{6}$ para os três grupos.

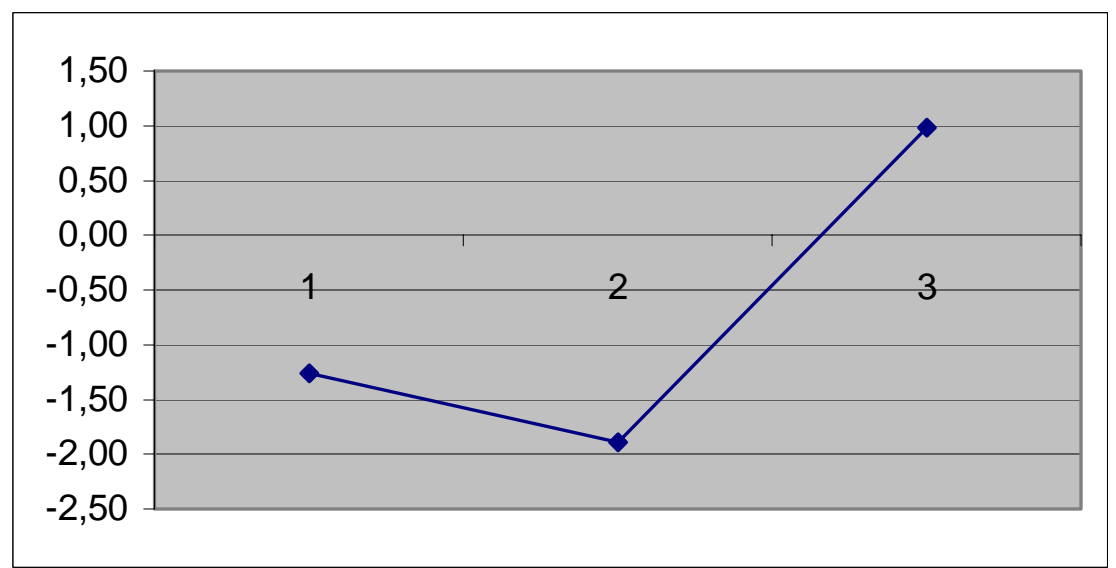

FIGURA 46: Alterações da medida FHP-DISTAL $\underline{6}$ nos três grupos.

Para a avaliação do comportamento do dentes inferiores, foram utilizadas as seguintes medidas: $\overline{1}$-GoMe e $\overline{6}$-GoMe.

O posicionamento dos incisivos inferiores no sentido vertical, aferido pela grandeza $\overline{1}-$ GoMe, apresentou resultados estatisticamente insignificantes para os três grupos, porém no grupo tratado com o aparelho AEB conjugado, os incisivos inferiores apresentaram menor extrusão, muito provavelmente devido ao apoio em acrílico nesta região, concordando portanto com diversos 
trabalhos $^{35,64,84}$, e não concordando com o trabalho de MARTINS ${ }^{88}$, de 1997, no qual afirma que os incisivos inferiores não demonstram alterações decorrentes do tratamento com o aparelho AEB conjugado. O grupo tratado com o aparelho AEB/IHG apresentou também menor extrusão dos incisivos inferiores quando comparados com o grupo controle, porém com resultado estatisticamente insignificante.

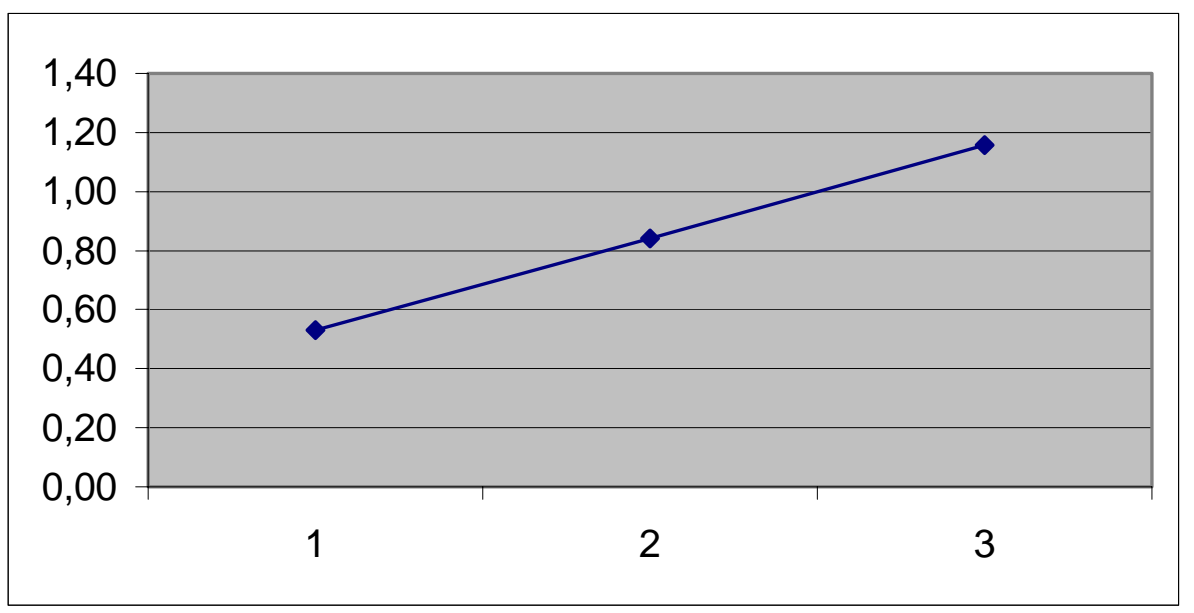

FIGURA 47: Alteração da grandeza 1-GoMe nos três grupos.

Com relação ao posicionamento dos primeiros molares inferiores no sentido vertical, os três grupos apresentaram um aumento na medida $\overline{6}$-GoMe, denotando portanto uma extrusão destes dentes, sendo que o grupo tratado com o aparelho AEB/IHG demonstrou uma maior extrusão destes dentes, seguido pelo grupo tratado com o aparelho AEB conjugado e por fim o grupo controle, porém estatisticamente não significantes. A extrusão maior apresentada pelo grupo tratado com o aparelho AEB/IHG deve-se muito provavelmente à tentativa de equilibrar o padrão de crescimento, pois os molares superiores neste grupo extruiram menos, porém sem significância estatística. Outros autores ${ }^{4,27}$ também relataram extrusão dos dentes posteriores inferiores quando utilizaram aparelhos ortopédicos para a correção da má oclusão de Classe II 1ª divisão. 


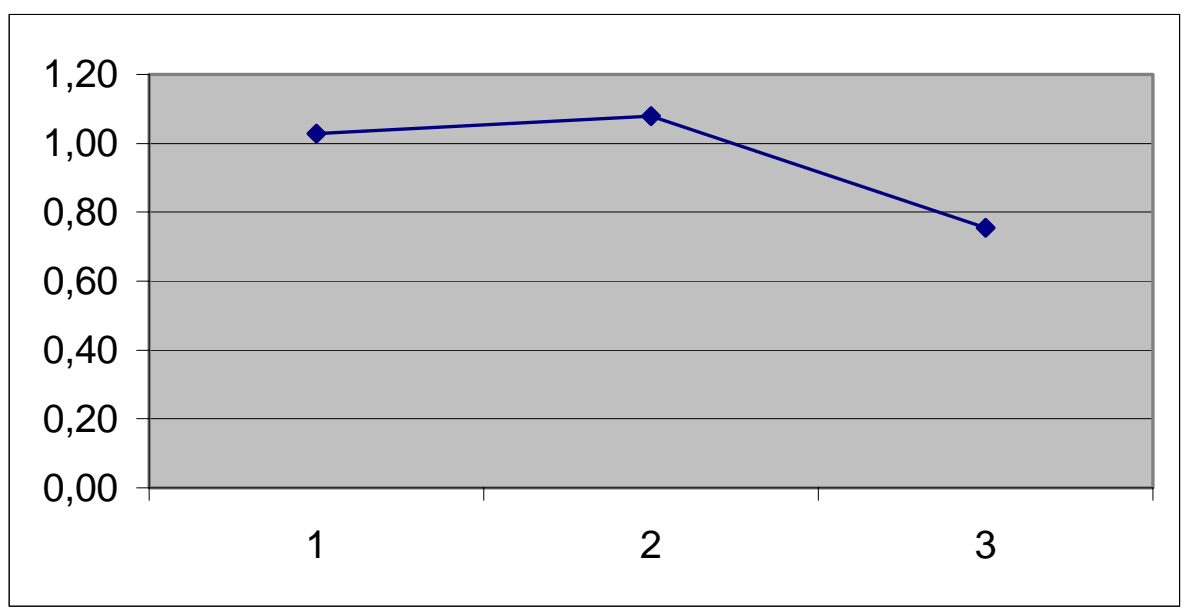

FIGURA 48: Alterações da medida $\overline{6}$-GoMe nos três grupos.

\subsubsection{Componente tegumentar:}

Para avaliar se o tratamento da Classe II, $1^{\text {a }}$ divisão com os aparelhos propostos neste estudo promoveram um perfil tegumentar mais harmonioso, foram utilizadas as seguintes grandezas cefalométricas: ANL, LS-E, Li-E.

O ângulo nasolabial (ANL) apresentou aumento maior no grupo não tratado, seguido pelo grupo tratado com o aparelho AEB conjugado, embora esta diferença seja estatisticamente insignificante.

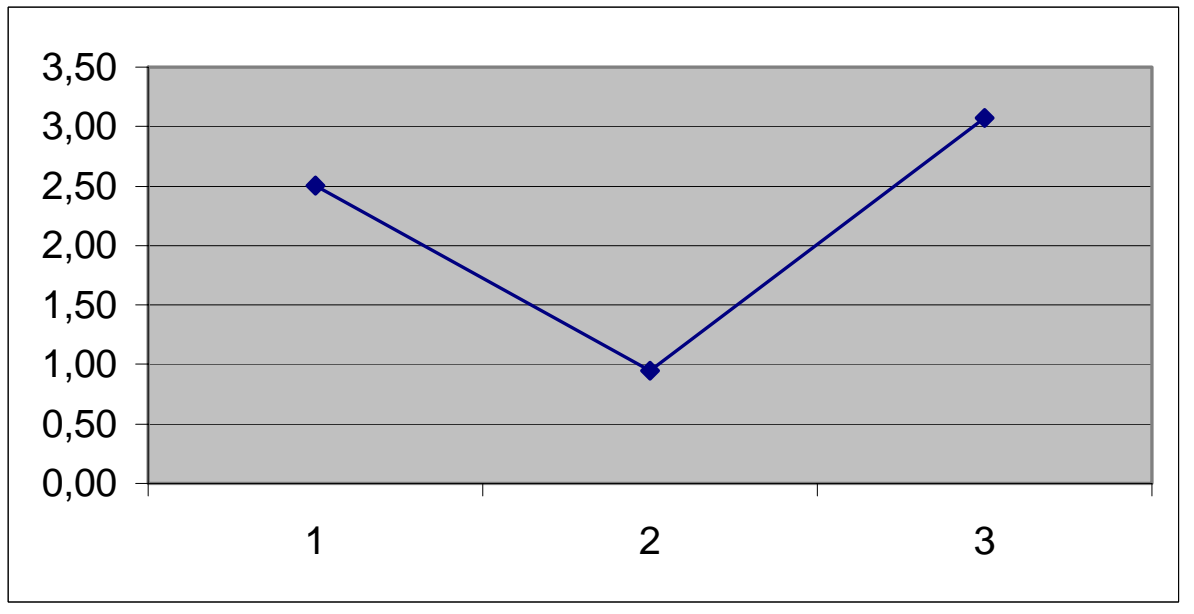

FIGURA 49: Alterações no ângulo nasolabial para os três grupos. 
O lábio superior e o inferior em relação à linha estética de Ricketts (Ls-E e Li-E), mostraram uma maior retrusão no grupo tratado com o AEB conjugado, seguido pelo grupo tratado com o aparelho AEB/IHG. Tal fato explica-se por meio dos lábios relacionarem-se diretamente com os dentes anteriores, e portanto acompanharem a movimentação destes ${ }^{2}$.

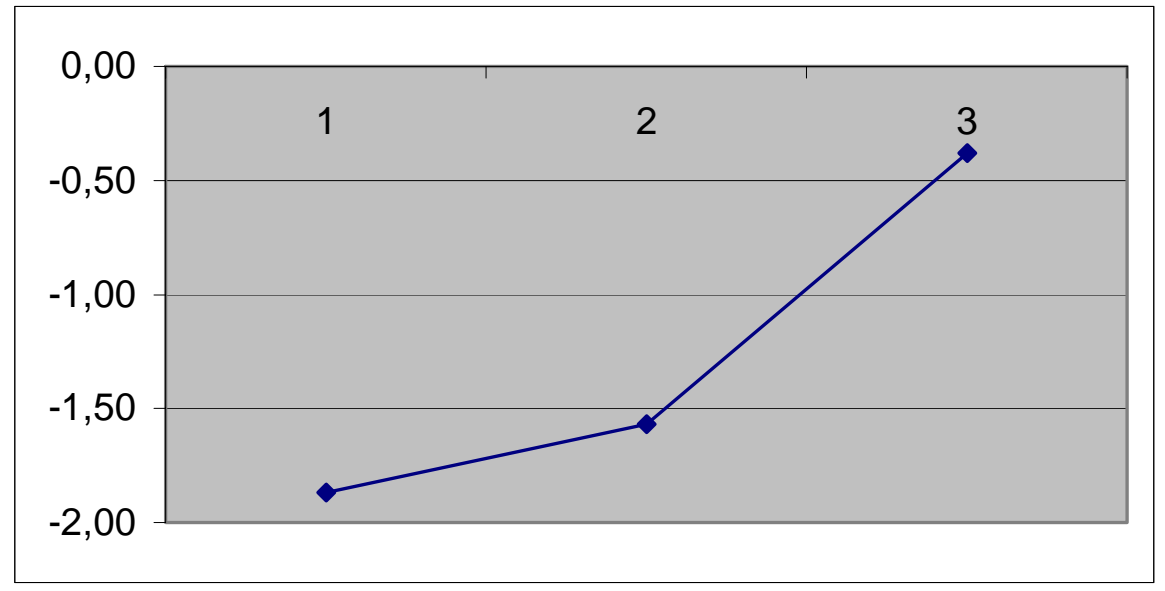

FIGURA 50: Alterações do lábio superior para os três grupos.

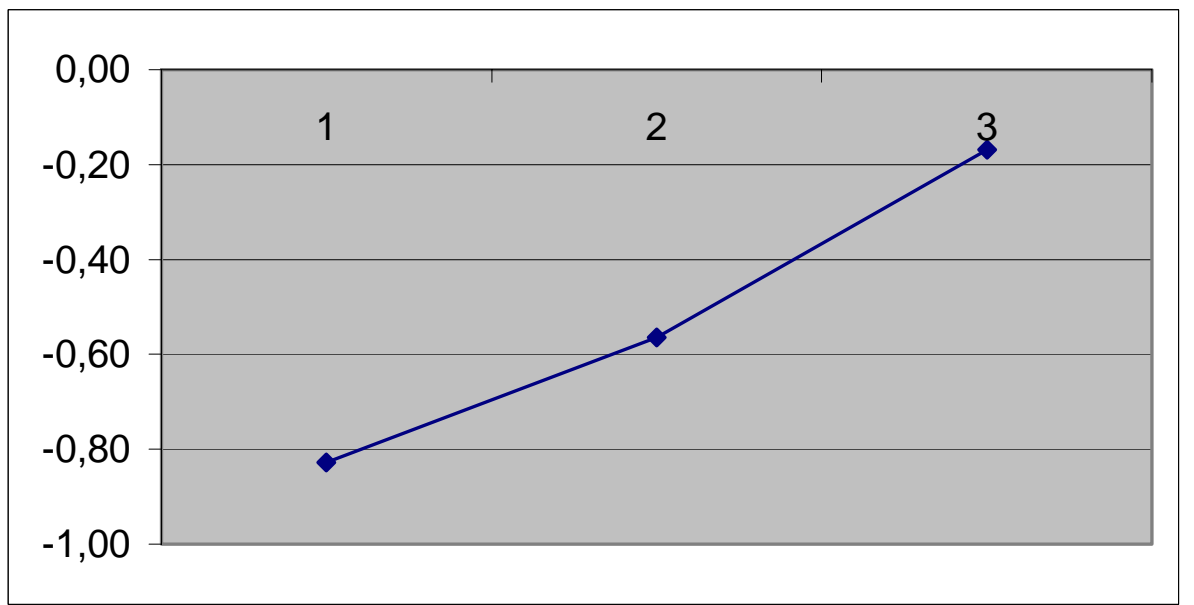

FIGURA 51: Alterações do lábio inferior para os três grupos.

Pode-se concluir neste tópico que estuda o perfil tegumentar, que os aparelhos estudados proporcionaram a retração dos lábios superior e inferior, melhorando conseqüentemente o padrão do perfil tegumentar dos jovens 
Classe II, $1^{\text {a }}$ divisão que normalmente apresentam uma deficiência postural dos lábios, com vestibuloversão dos incisivos superiores. A posição sagital dos lábios associou-se diretamente com a posição final dos incisivos.

\subsection{Considerações finais:}

A ortodontia possui uma infinidade de aparelhos para o tratamento e correção da Classe II, $1^{\text {a }}$ divisão, no entanto ainda há controvérsias quanto aos efeitos dentoesqueléticos e tegumentares, e em relação ao mecanismo de ação das diferentes abordagens terapêuticas. Os critérios de escolha do aparelho a ser instituído baseiam-se quase sempre em evidência clínica, científica e na morfologia craniofacial, e a definição do plano de tratamento se estabelece por meio das análises cefalométricas e faciais.

Em uma fase de crescimento facial ativo, é consenso geral entre os estudos $^{62,88}$, que os dentes e as bases ósseas podem ser efetivamente movimentadas e reposicionadas com aparelhos ortopédicos com a finalidade de corrigir ou amenizar a discrepância dentoesquelética. Ainda há dúvida com relação aos diferentes aparelhos para a correção da má oclusão de Classe II, $1^{\mathrm{a}}$ divisão e seus reais efeitos.

$\mathrm{Na}$ tentativa de esclarecer algumas das dúvidas com relação aos diversos tipos de terapias para tratamento da má oclusão de Classe II, $1^{\mathrm{a}}$ divisão, realizou-se este estudo.

A análise dos resultados mostrou que a interceptação da má oclusão de Classe II, $1^{\mathrm{a}}$ divisão com o AEB conjugado e com o AEB/IHG resultou em efeitos específicos e inerente a cada aparelho, porém com determinada similaridade. Porém, ambos protocolos de tratamento resultou em alterações esqueléticas, dentárias e tegumentares, clinicamente relevantes para a correção desta entidade. Esta afirmação torna-se evidente ao compararmos os grupos experimentais ao grupo controle (não tratado). 
Os efeitos do crescimento e desenvolvimento craniofacial nos pacientes com má oclusão de Classe II, $^{1 \mathrm{a}}$ divisão que não receberam tratamento mantiveram-se constantes, perpetuando portanto a má oclusão.

O tratamento com o aparelho AEB conjugado proporcionou alterações esqueléticas tanto na maxila quanto na mandíbula, e alterações dentárias. Houve diminuição das medidas SNA e FHP-A, representando a restrição do desenvolvimento maxilar para anterior, além da restrição no comprimento efetivo da mandíbula, quando comparado com o grupo controle. A protrusão da mandíbula, representada pela grandeza SNB, foi maior no grupo tratado com o aparelho AEB conjugado, apresentando-se em média 3 vezes maior quando comparado com o grupo controle, e em média2 vezes maior quando comparamos com o grupo tratado com o aparelho AEB/IHG.

A relação maxilomandibular foi conseqüentemente melhorada, diminuindo portanto a discrepância previamente observada.

Não se observou alterações estatisticamente significantes no padrão de crescimento craniofacial. Os incisivos superiores inclinaram-se para lingual no grupo tratado com o aparelho AEB conjugado, mostrando-se estatisticamente significante quando comparado com o grupo tratado com o aparelho AEB/IHG e com o grupo controle. A extrusão dos incisivos superiores e inferiores apresentou-se estável, demonstrando uma diferença estatisticamente insignificante para os três grupos estudados. Com relação à distalização dos primeiros molares superiores, os resultados apresentaram um valor maior para o grupo tratado com o aparelho AEB/IHG, seguido do grupo tratado com 0 aparelho AEB conjugado, tanto ao analisar a extrusão por meio de um ponto localizado na distal do primeiro molar superior, como ao analisar tomando como base um ponto localizado no ápice da raiz mesial do primeiro molar superior, sendo que esta similaridade mostra-nos um movimento para distal de corpo. Quando estuda-se a extrusão dos primeiros molares superiores e inferiores obtivemos resultados estatísticos não significantes. 
Constatou-se que diferentes abordagens terapêuticas podem corrigir uma mesma má oclusão, produzindo efeitos distintos sobre as estruturas ósseas, os dentes e tecidos moles. Ambos os protocolos de tratamento estudados nesta pesquisa mostraram-se eficazes na correção da má oclusão de Classe II, $1^{\mathrm{a}}$ divisão.

As alterações demonstradas pelo AEB conjugado neste estudo, contrariam diversas que relacionam os efeitos deste aparelho somente ao componente maxilar. Um aparelho que promova desoclusão posterior associado a uma força extrabucal é capaz de restringir o crescimento da maxila e liberar o crescimento da mandíbula, produzindo efeitos muitas vezes semelhantes àqueles angariados com os aparelhos que avançam a mandíbula como observado em vários trabalhos ${ }^{132135}$.

A extrapolação dos resultados desta pesquisa para a população em geral deve ser realizada com ressalvas considerando sempre as características da má oclusão, o padrão de crescimento e a colaboração dos pacientes com relação ao uso indicado de cada aparelho. 


\section{Conclusões}




\section{CONCLUSÕES}

Em relação às alterações apresentadas pelo tratamento com os aparelhos estudados e de acordo com a metodologia e resultados deste estudo, pode-se concluir:

7.1 Quanto às alterações esqueléticas:

\subsubsection{Componente maxilar:}

O deslocamento anterior e o comprimento efetivo da maxila foram restringidos significantemente pelo tratamento nos grupos experimentais.

\subsubsection{Componente mandibular:}

Ocorreu um aumento da mandíbula (Co-Gn) estatisticamente significante no grupo tratado com o aparelho AEB conjugado em relação ao grupo controle.

Já o deslocamento para anterior da mandíbula (SNB), não mostrou resultados estatisticamente significantes.

\subsubsection{Relação maxilomandibular:}

Os grupos tratados apresentaram uma melhora significante na relação maxilomandibular, com diminuição do ângulo ANB. 


\subsubsection{Relação Vertical:}

Nenhum dos grupos tratados produziu alterações significantes no padrão de crescimento craniofacial. O posicionamento vertical da maxila (SN.PP) também não se alterou. A Altura facial ântero-inferior (AFAI) não mostrou alteração significante.

\subsection{Componente dentoalveolar:}

No grupo tratado com o aparelho AEB conjugado houve uma inclinação significante para lingual dos incisivos superiores em relação aos outros grupos.

Os primeiros molares superiores apresentaram menor extrusão nos grupos experimentais, porém com alterações estatisticamente não significantes. No sentido ântero-posterior, verificou-se uma distalização (FHP-DISTAL6) de coroa destes dentes estatisticamente significante nos grupos tratados, e também uma distalização de raiz (FHP-ÁPICȨ) maior para os grupos experimentais, porém estatisticamente insignificantes.

Os incisivos e os primeiros molares inferiores não apresentaram alterações estatisticamente significantes nos três grupos avaliados, com relação à extrusão.

\subsection{Perfil tegumentar:}

O ângulo nasolabial não apresentou modificações significantes com o tratamento.

O lábio superior exibiu uma diminuição estatisticamente significante em sua protrusão, em ambos os grupos tratados. Já o lábio inferior não mostrou modificação estatisticamente significante em sua posição, nos três grupos avaliados. 


\section{Referências Bibliográficas}




\section{REFERÊNCIAS BIBLIOGRÁFICAS}

1. ALARASHI, M. et al. Morphometric analysis of the transverse dentoskeletal features of Class II malocclusion in the mixed dentition. Angle Orthodont., v.73, n.1, p.21-5, 2003.

2. ALMEIDA, M.R. Avaliação cefalométrica comparativa da interceptação da má oclusão de Classe II, 1a divisão utilizando o aparelho de Frankel e o Bionator de Balters. Bauru: Faculdade de Odontologia de Bauru, Universidade de São Paulo; 2000.

3. ALMEIDA, M.R. et al. O tratamento da Classe II, divisão 1 com o uso do AEB conjugado e aparelho fixo. Rev. Clin. Ortodon. Dental Press, v.1, n.3, p.6371, 2002.

4. ALMEIDA, M.R.; HENRIQUES, J.F.C.; URSI, W.J.S. Comparative study of the Fränkel (FR-2) and bionator appliances in the treatment of Class II malocclusion. Amer. J. Orthodont. Dentofac. Orthop., v.121, n.5, p.458-66, 2002.

5. ALMEIDA, R.R. et al. Utilização do AEB conjugado na interceptação da má-oclusão de Classe II, 1a divisão. Rev. APCD, v.56, n.4, p.308-12, 2002.

6. ALMEIDA, R.R. et. al. Ortodontia preventiva e interceptora: mito ou realidade. Rev. Dental Press Ortodon Ortop Facial, v.4, n.6, p.87-108, 1999.

7. ALMEIDA-PEDRIN, R.R. Efeitos cefalométricos do aparelho extrabucal conjugado (Splint maxilar) e do Bionator, no tratamento da má oclusão de Classe II, 1 divisão. [Doutorado]. Bauru: Faculadade de Odontologia de Bauru da Universidade de São Paulo; 2003.

8. ALTEMUS, L.A. Horizontal and vertical dentofacial relationships in normal and Class II, division 1 malocclusion in girls 11-15 years. Angle Orthodont., v.25, p.120-37, 1955. 
9. ANDERSON, D.L.; POPOVICH, F. Lower cranial height vs craniofacial dimension in Anlge Class II malocclusion. Angle Orthodont., v.53, n.3, p.253-60, 1983.

10. ANDERSON, G.M. On the diagnosis and treatment of "distocclusion". Amer. J. Orthod. Oral Surg., v.32, n.1, p.88-94, 1946.

11. ANGLE, E.H. Classification of malocclusion. Dent. Cosmos, v.41, n.3, p.248-64 350-57, 1899.

12. ANGLE, E.H. Malocclusion of the teeth. 7 ed. Philadelphia: S.S. White; 1907.

13. BAALACK, I.; POULSEN, A. Occipital anchorage for distal movement of the maxillary first molars. Acta Odont Scand, v.24, n.1, p.307-25, 1966.

14. BACCETTI, T. et al. Early dentofacial features of Class II malocclusion: A longitudinal study from the deciduous through the mixed dentition. Amer. J. Orthod. Dentofac. Orthop., v.111, n.5, p.502-509, 1997.

15. BAKER, J.N. apud NELSON, B.G. What does extraoral anchorage accomplish? Amer. J. Orthod. Dentofac. Orthop., v.38, n.6, p.422-34, 1952.

16. BARROS, C. C. Ortodontia - diagnóstico e planejamento clínico. São Paulo: Artes Médicas; 1998.

17. BASS, N.M. Dento-facial orthopaedics in the correction of Class II malocclusion. Brit. J. Orthodont., v.9, n.1, p.3-31, 1982.

18. BAUMRIND, S.; FRANTZ, R. C. The reliability of head film measurements. Landmark identification,. Amer. J. Orthod. Dentofac. Orthop., v.60, n.2, p.111-27, 1971. 
19. BAUMRIND, S.; KORN, E. L. Patterns of change in mandibular and facial shape associated with the use of forces to retract the maxilla. Amer. J. Orthod. Dentofac. Orthop., v.80, n.1, p.37-47, 1981.

20. BAUMRIND, S.; KORN, E. L.; ISAACSON, R. J.; WEST, E. E.; MOLTHEN, R. Quantitative analysis of the orthodontic and orthopedic effects of maxillary traction. Amer. J. Orthod. Dentofac. Orthop., v.84, n.5, p.384-98, 1983.

21. BAUMRIND, S.; KORN, E. L.; MOLTHEN, R.;WEST, E. E. Changes in facial dimensions associated with the use of forces to retract the maxilla. Amer. $\mathbf{J}$. Orthod. Dentofac. Orthop., v.80, n.1, p.17-30, 1981.

22. BAUMRIND, S.; MOLTHEN, R.; WEST, E. E.; MILLER, D.M. Mandibular plane changes during maxillary retraction - parte 2. Amer. J. Orthod. Dentofac. Orthop., v.74, n.6, p.603-20, 1978.

23. BERTOZ, F.A. et. al. Características cefalométricas de pacientes com má oclusão Classe II. Revista APEO, v.1, n.1, p.35-41, 2003.

24. BILLET, T.; PAUW, G.; DERMAUT, L. Location of the centre of resistance of the upper dentition and the nasomaxillary complex. An experimental study. Europ. J. Orthod.,, v.23, n.3, p.263-73, 2001.

25. BISHARA, S.E. Mandibular changes in persons with untreated and treated Class II division 1 malocclusion. Amer. J. Orthodont. Dentofac. Orthop., v.113, n.6, p.661-73, 1998.

26. BISHARA, S.E. et al. Changes in dentofacial structures in untreated Class II division 1 and normal subjects: A longitudinal study. Angle Orthodont. v.67, n.1, p.55-66, 1997.

27. BISHARA, S.E.; ZIAJA, R.R. Functional appliances: a review. Amer. J. Orthod. Dentofac. Orthop., v.95, n.3, p.250-8, 1989. 
28. BOECLER, P. R. et. al. Skeletal changes associated with extraoral therapy: na evaluation of 200 consecutivelly treated cases. Angle Orthod., v.59, n.4, p.263-270, 1989.

29. BRANDÃO, A.M.B.; DOMÍNGUEZ-RODRIGUEZ, G.C.; CAPELOZZA FILHO,

L. Avaliação comparativa entre as características da má oclusão Classe II, divisão 1 obtidas pela cefalometria e análise facial subjetiva. Rev. Dental Press Ortod. Ortop. Fac., v.6, n.2, p.33-40, 2001.

30. BRANDT, H. C.; SHAPIRO, P. A.; KONICH, V. G. Experimental and postexperimental effects of posteriorly directed extraoral traction in adult Macaca fascicularis. Amer. J. Orthod. Dentofac. Orthop., v.75, n.3, p.30117, 1979.

31. BRODIE, A.G. Cephalometric appraisal of orthodontic results. Angle Orthodont., v.8, n.4, p.261-65, 1938.

32. BROWN, P. A. A cephalometric evaluation of high-pull molar headgear and facebow neck strap therapy. Amer. J. Orthod. Dentofac. Orthop., v.74, n.6, p.621-32, 1978.

33. BURKE, M.; JACOBSON, A. Vertical changes in high-angle Class II, division 1 patients treated with cervical or occipital pull headgear. Amer. J. Orthod. Dentofac. Orthop., v.102, n.6, p.501-8, 1992.

34. BUSCHANG, P.H. et al. Mathematical models of longitudinal mandibular growth for children with normal and untreated Class II, division 1 malocclusion. Europ. J. Orthodont., v.10, n.3, p.227-34, 1988.

35. CALDWELL, S.F.; HYMAS, A.; TIMM, T.A. Maxillary traction splint: a cephalometric evaluation. Amer. J. Orthodont., v.85, n.5, p.376-84, 1984.

36. CARTER, N.E. Dentofacial changes in untreated Class II Division 1 subjects. Brit. J. Orthod., v.14, n.4, p.225-34, 1987. 
37. CELLIER, F. apud Nelson B.G. What does extraoral anchorage accomplish? Amer. J. Orthod. Dentofac. Orthop., v.38, n.6, p.422-34, 1952.

38. CHACONAS, S. J.; CAPUTO, A. A.; DAVIS, J. C. The effects of orthopedic forces an the craniofacial complex utilizing cervical and headgear appliances. Amer. J. Orthod. Dentofac. Orthop., v.69, n.5, p.527-39, 1976.

39. COUSINS, A.J.P.; CLARK, W.J. P., apud FERGUSON, J.W. p.48. Extra-oral traction - theoretical considerations and the development of a removable appliance technique. Transactions of the British Society for the study of orthodontics, p.37-44, 1965.

40. CRAIG, C.E. The skeletal patterns characteristic of class I and class II, division I malocclusions in norma lateralis. Angle Ortodont., v.21, n.1, p.44-56, 1951.

41. DAHLBERG, G. Statistical methods for medical and biological students. New York: Interscience; 1940.

42. DE CASTRO, N. The challenge of Class II, division 1 malocclusion. Amer. J. Orthodont., v.46, n.11, p.829-33, 1960.

43. DIBBETS, J.M.H. Morphological associations between the Angle classes. Europ. J. Orthod.,, v.18, p.111-118, 1996.

44. DRELICH, R.C. A cephalometric study of untreated class II, division 1 malocclusion. Angle Orthodont., v.18, n.3-4,, p.70-5, 1948.

45. ELDER, J. R.; TUENGE, R. H. Cephalometric and histologic changes produced by extraoral high-pull traction to the maxilla in Macaca mulatta. Amer. J. Orthod. Dentofac. Orthop., v.66, n.6, p.599-617, 1974. 
46. EPSTEIN, W. N. Analysis of changes in molar relationships by means of extra-oral anchorage (Head-cap) in treatment of malocclusion. Res. Illin., v.18, n.3, p.63-9, 1948.

47. FARRAR, J.N. Orthodontics: an historical review of its and evolution. Saint Louis. Mosby, p.885, 1886.

48. FERGUSON, J.W. A new method of attaching headgear to upper removable appliances. Brit. J. Orthodont., v.10, n.1, p.48-9, 1983.

49. FIROUZ, M.; ZERNIK, J.; NANDA, R. Dental and orthopedic effects of high-pull headgear in treatment of Class II, division 1 malocclusion. Amer. J. Orthod. Dentofac. Orthop., v.102, n.3, p.429-38, 1992.

50. FISCHER, B. Treatment of Class II, division 1 (Angle). Variation and the "individuality hypothesis". Angle Orthodont., n.20, p.116-34, 1950.

51. FISK, G.V. The morfology and physiology of distoclusion. Amer. J. Orthodont., v.39, p.3-12, 1953.

52. FONSECA, R. C. Análise Cefalométrica - Diagnóstico e Planejamento Ortodôntico. São Paulo: Editora Santos; 2001.

53. FOTIS, V. et al. Vertical control as an important ingredient in the treatment of severe sagital discrepancies. Amer. J. Orthodont., v.86, n.3, p.224-32, 1989.

54. FREITAS, M.R. et. al. Prevalência das más oclusões em pacientes inscritos para tratamento ortodôntico na Faculdade de Odontologia de Bauru. Rev. Fac. Odont. Bauru, v.10, n.3, p.164-169, 2002.

55. GHAFARI, J.; SHOFER, F. S.; JACOBSON-HUNT, U.; MARKOWITZ, D. L.; LASTER, L. L. Headgear versus function regulator in the early treatment of Class II, division 1 malocclusion: a randomized clinical trial. Amer. J. Orthod. Dentofac. Orthop., v.113, n.1, p.51-61, 1998. 
56. GILMORE, W.A. Morphology of the adult mandible in Class II, division 1 malocclusion and in excellent oclusion. Angle Orthodont., v.20, n.3, p.13746, 1950.

57. GURGEL, J.A.; ALMEIDA, R.R.; PINZAN, A. Avaliação comparativa das alterações esqueléticas maxilomandibulares entre jovens do sexo masculino, com má oclusão de Classe II, 1a divisão, não tratados e com oclusão normal. Rev. Dental Press Ortod. Ortop. Fac., v.5, n.2, p.20-28, 2000.

58. HELLMAN, M. Studies on the etiology of Angle`s Class II malocclusal manifestations. Int. J. Orthodont., v.8, p.129-59, 1922.

59. HENRIQUES, J. F. C. et. al. A ancoragem extrabucal occipital (IHG) na correção da maloclusão de Classe II, divisão 1, associada ao aparelho fixo e à extração de quatro pré-molares. J Bras Ortodon Ortop Facial, v.5, n.29, p.7-16, 2000.

60. HENRIQUES, J. F. C. et. al. Controle da dimensão vertical com o aparelho removível conjugado à ancoragem extrabucal no tratamento da Classe II,1a. divisão. Rev. Clin. Ortodon. Dental Press, v.2, n.4, p.53-64, 2003.

61. HENRIQUES, J. F. C.; FREITAS, M. R.; HAYASAKI, S. M. Principais indicações e efeitos da ancoragem extrabucal occipital (I.H.G.) no tratamento de jovens com má oclusão de Classe II, 1a. divisão de Angle: apresentaçào de um caso clínico. Rev. Dental Press Ortod. Ortop. Fac., v.4, n.2, p.33-38, 1999.

62. HENRIQUES, J. F.C. et. al. Tratamento da má oclusão de Classe II, 1a. divisão em pacientes com padrão de crescimento vertical, utilizando a ancoragem extrabucal. Relato de dois casos clínicos. Rev. Dental Press Ortod. Ortop. Fac., v.5, n.4, p.53-61, 2000.

63. HENRIQUES, J.F.C. Estudo cefalométrico comparativo, de três tipos de ancoragem extrabucal, sobre as estruturas dentoesqueléticas, em 
pacientes com classe II, 1 divisão. [Tese (Livre Docência)]. Bauru: Faculdade de Odontologia de Bauru - Unversidade de São Paulo; 1993.

64. HENRIQUES, J.F.C. et al. Modified maxillary splint for class II, division 1 treatment. J. Clin. Orthodont., v.25, n.4, p.239-45, 1991.

65. HENRIQUES, J.F.C. et al. Utilização do aparelho removível conjugado à ancoragem extrabucal para a correção da má oclusão de Classe II, 1a divisão, com sobremordida profunda. Rev. Dental Press Ortod. Ortop. Fac., v.2, n.2, 12-18 1997.

66. HENRIQUES, J.F.C. et al. Estudo longitudinal das características da má oclusão de Classe II, 1a divisão sem tratamento, em jovens Brasileiros, Leucodermas, por um período médio de 3 anos. Rev. Dental Press Ortod. Ortop. Fac., v.3, n.3, p.52-66, 1998.

67. HENRIQUES, J.F.C.; FREITAS, M.R.; SANTOS PINTO, C.C.M. Correção de uma má oclusão de classe II, divisão 1, com protrusão maxilar, utilizando o arco facial conjugado a um aparelho removível (AEB conjugado). Ortodontia, v.24, n.3, p.14-18, 1991.

68. HENRY, R.G. , v., n., p., Apr. . A classification of Class II, division 1 malocclusion. Angle Orthodont., v.27, n.2, p.83-92, 1957.

69. HOUSTON, W.J.B. The analysis of errors in orthodontic measurements. Amer. J. Orthod. Dentofac. Orthop., v.83, n.5, p.382-90, 1983.

70. INTERLANDI, S. Apresentação de um caso clínico. Ortodontia, v.2, n.1, p.11-16, 1969.

71. JACOBS, T.; SAWAENGKIT, P. National Institute of Dental and Craniofacial Research Efficacy Trials of Bionator Class II Treatment: A Review. Angle Orthodont., v.72, n.6, p.571-5, 2002. 
72. JOFFE, L.; JACOBSON, A. The maxillary orthopedic splint. Amer. J. Orthodont., v.75, n.1, p.54-69, 1979.

73. KAMITSUJI, I. K. N. Estudo cefalométrico dos efeitos do uso do aparelho extrabucal tipo I.H.G., em pacientes portadores de má-oclusão de Classe II, divisão 1a. de "Angle" [Monografia]. São Paulo: Universidade Paulista; 1998.

74. KARLSEN, A.T. Craniofacial morphology in children with Angle Class II-1 malocclusion with and without deepbite. Angle Orthodont. v.64, n.6, p.43746, 1994.

75. KEAN, M.R. Some aspects of facial depth in Class II, division 1 malocclusion. Angle Orthodont., v.28, n.1, p.1-11, 1958.

76. KING, T.B. A cephalometric study of the positional relationship of the incisors and apical bases to each other in Class I and Class II, division 1. Amer. J. Orthodont., v.48, n.8, p.629-30, 1962.

77. KINGSLEY, N.W. Orthodontics: an historical review of its origin and evolution. Saint Louis, Mosby, p.492, 1875.

78. KLOCKE, A.; NANDA, R.S.; KAHL-NIEKE, B. Skeletal Class II patterns in the primary dentition. Amer. J. Orthodont. Dentofac. Orthop., v.121, n.6, p.596-601, 2002.

79. KLOEHN, S. J. A new approach to the analysis and treatment in mixed dentition. Amer. J. Orthod. Dentofac. Orthop., v.39, n.3, p.161-86, 1953.

80. KRAGT, G.; DUTERLOO, H. S.; ALGRA, A. M. Initial displacements and variations of eight human child skulls owing to high-pull headgear traction determined with laser holography. Amer. J. Orthod. Dentofac. Orthop., v.89, n.5, p.399-406, 1986. 
81. LUNDSTRÖM, A.F. A contribution to the discussion concerning the nature of distoclusion. Dent. Cosmos, v.27, n.10, p.956-69, 1925.

82. MAIA, A. et al. Estudo cefalométrico das características da má oclusão de Classe II/1, em brasileiros da região nordeste, em fase de dentadura mista (parte 1). Ortodontia, v.31, n.2, p.53-68, 1998.

83. MAJ, G.; LUZI, C.; LUCCHESE, P. A cephalometric appraisal of Class II and Class III malocclusions. Angle Orthodont., v.30, n.1, p.26-34, 1960.

84. MALTAGLIATI, L.A. Estudo comparativo das alterações dentoesqueléticas da má oclusão de Classe II, 1a divisão de Angle, nos jovens sem tratamento e nos submetidos a dois tipos de aparelho ortodôntico. [Dissertação (Mestrado)]. Bauru: Faculdade de Odontologia de Bauru, Universidade de São Paulo; 1997.

85. MARCONDES, A.R. Integration of certain variants as a determinant of facial morphology. Illinois: University of Illinois; 1955.

86. MARTIN, R.A. An analysis of normal cases and Class II, division 1 cases by cephalometric evaluation. Amer. J. Orthodont., v.44, n.2, p.147, 1958.

87. MARTINS, D.R. et. al. Atlas de desenvolvimento craniofacial. São Paulo: Santos; 1998.

88. MARTINS, J.C.R. Avaliação cefalométrica comparativa dos resultados da interceptação da má oclusão de Classe II, divisão 1a de Angle, efetuados com o aparelho extrabucal ou com o bionator. [Tese (Livre-docência)]. Araraquara: Faculdade de Odontologia de Araraquara, Universidade Estadual Paulista; 1997.

89. MCCALLIN, S.G. apud NELSON, P.T. p.45. Extra-oral traction in orthodontics. Dent. Practit. Rec., v.12, n.1, p.25-38, 1961. 
90. McNAMARA JÚNIOR, J.A. Components of Class II malocclusion in children 8-10 years of age. Angle Orthodont., v.51, n.3, p.177-202, 1981.

91. McNAMARA JÚNIOR, J.A. A method of cefalometric evaluation. Amer. J. Orthod. Dentofac. Orthop., v.86, n.6, p.449-69, 1984.

92. MELDRUN, R. J. Alterations in the upper facial growth of Macaca mulatta resulting from high-pull headgear. Amer. J. Orthod. Dentofac. Orthop., v.67, n.4, p.393-411, 1975.

93. MIDTGARG, J.; BJORK, G.; LINDER-ARONSON, S. Reproducibility of cephalometric landmarks and errors of measurements of cephalometric cranial distances. Angle Orthod., v.44, n.1, p.56-61, 1974.

94. MOYERS, R.E. et al. Differential diagnosis of Class II malocclusions. Part 1. Facial types associated with Class II malocclusions. Amer. J. Orthodont., v.78, n.5, p.477-94, 1980.

95. NAHÁS, A. C. R. Estudo cefalométrico das alterações dento-esqueléticas da má oclusão de Classe II, divisão 1, tratada com o aparelho de Herbst e com o aparelho extrabucal de tração occipital. [Doutorado]. Bauru: Faculdade de Odontologia de Bauru da Universidade de São Paulo; 2004.

96. NELSON, W.E.; HIGLEY, L.B. The length of mandibular basal bone in normal occlusion and Class I malocclusion compared to Class II, division 1 malocclusion. Amer. J. Orthodont., v.34, n.7, p.610-7, 1948.

97. NGAN, P.W.; BYCZEK, E.; SCHEICK, J. Longitudinal evaluation of growth changes in Class II division 1 subjects. Sem. Orthod., v.3, n.4, p.222-31, 1997.

98. NOUER, P. R. A.; RONDELLI, C. E. M.; WATANABE, P.; MIYAMURA, Z. Y.; TAVANO, O.; ARSATI, Y. B. O. L. Arco extrabucal com inserção palatina conjugado com placa expansora encapsulada: considerações biomecânicas 
tridimensionais. Rev. Dental Press Ortod. Ortop. Fac., v.9, n.2, p.05-20, 2004.

99. OPPENHEIM, A. Biologic orthodontic therapy and reality. Angle Orthodont, v.6, n.3, p.153-83, 1936.

100. PFEIFFER, J.P.; GROBÉTY, D. The Class II malocclusion: Differential diagnosis and clinical application of activators, extraoral traction, and fixed appliances. Amer. J. Orthodont., v.68, n.5, p.499-544, 1975.

101. PIRES, et. al. Estudo cefalométrico comparativo das alterações verticais ocorridas em pacientes submetidos ao uso do AEB ortopédico, considerando dois diferentes pontos de aplicação de força: anterior e posterior. J Bras Ortodon Ortop Facial, v.8, n.45, p.208-222, 2003.

102. PLINT, D.A. apud FERGUSON, J.W. A method of treating Class II, div. 1 cases without using the lower arch for anchorage or extraction. Transactions of the British Society for the study of orthodontics, p.49-55, 1961.

103. POULTON, D. R. Changes in class II malocclusions with and without occipital headgear therapy. Angle Orthod. v.29, n.4, p.234-250, 1959.

104. POULTON, D. R. A three-year survey of Class II malocclusions with and without headgear therapy. Amer. J. Orthod. Dentofac. Orthop., v.34, n.3, p.181-93, 1964.

105. POULTON, D. R. The influence of extraoral traction. Amer. J. Orthod. Dentofac. Orthop., v.53, n.1, p.8-18, 1967.

106. PROFFIT, W.R. Contemporary Orthodontics. 2 ed. St. Louis: Mosby Year Book; 1993. 
107. RENFROE, E.W. A study of the facial patterns associated with Class I, Class II, division 1, and Class II, division 2 malocclusions. Angle Orthodont., v.18, n.1-2, p.12-15, 1948.

108. RIEDEL, R.A. The relation of maxillary structures to cranium in malocclusion and in normal occlusion. Angle Orthodont., v.22, n.3, p.142-5, 1952.

109. RIGHELLIS, E. G. Treatment effects of Fränkel, Activator and Extraoral traction appliances. Angle Orthod., v.53, n.2, p.107-21, 1983.

110. ROCK, W.P. J. The use of extra-oral traction with removable appliances. Brit. Dent., v.168, n.10, p.403-7, 1990.

111. ROSENBLUM, R.E. Class II malocclusion: mandibular retrusion or maxillary protrusion. Angle Orthodont. v.65, n.1, p.49-62, 1995.

112. ROTHSTEIN, T.L. Facial morphology and growth from 10 to 14 years of age in children presenting Class II, division 1 malocclusion: A comparative roentgenographic cephalometric study. Amer. J. Orthodont. v.60, n.6, p.61920, 1971.

113. ROTHSTEIN, T.L.; YOON-TARLIE, C. Dental and facial skeletal characteristics and growth of males and females with Class II, division 1 malocclusion between the ages of 10 and 14 (revisited) - Part 1: characteristics of size, form and position. Amer. J. Orthodont. Dentofac. Orthop., v.117, n.3, p.320-32, 2000.

114. RYGH, P.; MOYERS, R. E. Sistemos de forças e respostas dos tecidos às forças em ortodontia e ortopedia facial. In: MOYERS, R. E. Ortodontia. Rio de Janeiro: Guanabara Koogan; 1991. p. 259-80.

115. SALZMANN, J.A. Criteria for extraction in orthodontic therapy related to dentofacial development. Amer. J. Orthodont. v.35, p.584-610, 1949. 
116. SANTOS, M.A.C. Caracterização cefalométrica da Classe II, 1a divisão, esquelética. Bauru: Universidade de São Paulo; 2003.

117. SANTOS PINTO, A. et al. O aparelho extra-bucal de Thurow modificado no tratamento da Classe II com mordida aberta: caso clínico. Rev. Dental Press Ortod. Ortop. Fac., v.6, n.1, p.57-62, 2001.

118. SARHAN, O.A.; HASHIM, H.A. Dento-skeletal components of ClassII malocclusions for children with normal and retruded mandibles. J. Clin. Pediat. Dent., v.18, n.2, p.99-103, 1994.

119. SASSOUNI, V. The Class II syndorme: differencial diagnosis and treatment. Angle Orthodont., v.40, p.325-41, 1970.

120. SCANAVINI, M. A. Contribuição ao estudo das modificações no padrão esquelético da face, distanciadas do ponto de aplicação da força extra-oral em ortodontia. Ortodontia, v.9, n.1, p.28-48, 1976.

121. SEÇKIN, O.; SURUCU, R. Treatment of class II, division 1 cases with a maxillary traction splint.: Quintessence; 1990.

122. SERVOSS, J.M. Classification of occlusion. J. Dent. Child. v.42, n.1, p.28-30, 1975.

123. SMITH, R. J.; BURSTONE, C. J. Mechanics of tooth movement. Amer. J. Orthod. Dentofac. Orthop., v.85, n.4, p.294-307, 1984.

124. THUROW, R.C. Craniomaxillary orthopedic correction with the en masse dental control. Amer. J. Orthodont., v.68, n.6, p.601-24, 1975.

125. ÜNER, O.; EROGLU, E.Y. Effects of a modified maxillary orthopaedic splint: a cephalometric evaluation. Europ. J. Orthodont., v.18, p.269-86, 1996. 
126. URSI, W.J.S. Alteração clínica da face em crescimento: uma comparação cefalométrica entre os aparelhos extrabucal cervical, Frankel (FR-2) e Herbst no tratamento das oclusões de Classe II, primeira divisão de Angle. Bauru: Faculdade de Odontologia de Bauru, Universidade de São Paulo; 1993.

127. URSI, W.J.S.; McNAMARA JUNIOR, J. Crescimento craniofacial em pacientes apresentando maloclusão de Classe II e oclusão normal entre os 10 anos e os 12 anos de idade. Rev. Dental Press Ortod. Ortop. Fac., v.2, n.5, p.49-59, 1997.

128. VALE, D.M.V. Avaliação cefalométrica das estruturas dentoesqueléticas em jovens portadores de Classe II, divisão 1, brasileiros, leucodermas e de origem mediterrânea. Bauru; 1985.

129. VIGORITO, J.W. Estudo comparativo de algumas características mandibulares em maloclusões de Classe I e Classe II, divisão 1, de Angle. Rev. Fac. Odont. USP, v.11, n.1, p.75-82, 1973.

130. VON DER HEYDT, K. E. An analysis of the clinical enity, maxillary protrusion, with relation to classification, diagnosis and treatment. Amer. J. Orthodont., v.37, p.842-57, 1951.

131. WATSON, W. G. A computerized appraisal of the high-pull face-bow. Amer. J. Orthod. Dentofac. Orthop., v.62, n.6, p.561-79, 1972.

132. WHEELER, T.T. et al. Effectiveness of early treatment of Class II malocclusion. Amer. J. Orthodont. Dentofac. Orthop., v.121, n.1, p.9-17, 2002.

133. WOODSIDE, D.G. Cefalometric roentgenography. In: CLARK, J.W., Clinical dentistry. New York, Harper \& Row, . 1980. 
134. YOSHIDA, N.; JOST-BRINKMANN, P. G.; YAMADA, Y. Initial tooth movement under extraoral force and considerations for controlled molar movement. Angle Orthod., v.65, n.3, p.199-208, 1995.

135. YOU, Z.H. et al. Dentoalveolar changes related to mandibular forward growth in untreated Class II persons. Amer. J. Orthodont. Dentofac. Orthop., v.120, n.6, p.598-607, 2001. 
Abstract 
ABSTRACT

\section{Comparative cephalometric study of alterations in the Angle Class II} division 1 malocclusion in young individuals treated with two types of headgear

This study conducted a cephalometric evaluation of the dental, skeletal and soft tissue alterations in young individuals with Class II division 1 malocclusion treated with the maxillary splint and high-pull headgear (HPH). The study groups were compared to a control group presenting the same malocclusion matched for gender, age and period of observation. A total of 150 lateral cephalograms of 75 young individuals were analyzed, which were divided into three groups with 25 individuals each. The individuals in group 1 were treated with the maxillary splint, presented an initial mean age of 10 years and were observed for 1 year and 4 months. Group 2 was treated with the highpull headgear $(\mathrm{HPH})$, had an initial mean age of 10 years and was followed for 1 year and 4 months. The subjects in group 3 were kept as controls, presented an initial mean age of 10 years and were observed for a mean period of 1 year and 4 months. All measurements were submitted to statistical analysis. The results demonstrated that interception of the Class II division 1 malocclusion in the study groups was significant, presenting specific effects inherent to each appliance investigated. The anterior maxillary displacement was significantly restricted in the study groups compared to the control group, especially for the group treated with $\mathrm{HPH}$. The mandible presented a statistically significant increase in effective growth (Co_Gn) in the group treated with the maxillary splint, yet its anterior displacement (SNB) did not present significant alterations. The maxillomandibular relationship was significantly improved in the study groups. The vertical components did not present statistically significant differences between groups. With regard to the dentoalveolar alterations in the maxillary arch, the group treated with the maxillary splint presented a significant restriction in buccal inclination of the maxillary incisors. Distal movement of the maxillary molars was significant for both study groups, being larger for the group treated with the $\mathrm{HPH}$, especially as to the crown movement (FHP_DISTAL6). Extrusion of the mandibular incisors was more restricted 
(1_GoMe) in the group treated with the maxillary splint, followed by the group treated with the $\mathrm{HPH}$, yet with non-statistically significant outcomes. Extrusion of the mandibular molars was also non-significant between groups. With regard to the soft tissue profile, the nasolabial angle was not changed by treatment, as well as the position of the lower lip. On the other hand, the upper lip presented more retrusion in the group treated with the maxillary splint, followed by the group treated with the $\mathrm{HPH}$, with statistically significant difference between the study groups and the control group. Therefore, it was concluded that both treatment protocols provided clinically relevant skeletal, dental and soft tissue alterations for correction of the Class II division 1 malocclusion. 
Apêndice 
APÊNCIDE 1 - Valores iniciais de todas as variáveis dos três grupos

\begin{tabular}{|c|c|c|c|c|c|c|c|c|c|c|}
\hline Pacientes & Grupo & Gênero & Idade I & Idade F & Tempo & SNA $\mathrm{i}$ & fhp-A $\mathrm{i}$ & $\mathrm{COA} \mathrm{i}$ & SNB i & CoGni \\
\hline Amanda $\mathrm{M}$, Caredo & AEB conj & $\mathrm{F}$ & 131 & 151 & 20 & 89,5 & 46,3 & 83,1 & 80,8 & 101,8 \\
\hline Ana $\mathrm{Cl}$ udia Andre & AEB conj & $\mathrm{F}$ & 109 & 118 & 9 & 78,8 & 44 & 77,4 & 77,2 & 104 \\
\hline Ana Paula Rodrigh & AEB conj & $\mathrm{F}$ & 113 & 131 & 18 & 86,8 & 48,4 & 77,1 & 79,7 & 92,2 \\
\hline Andre Luis Gimene & AEB conj & $\bar{M}$ & 117 & 130 & 13 & 84,3 & 46,7 & 81,2 & 77,9 & 101,4 \\
\hline Carlos E, Cordeir & AEB conj & M & 129 & 151 & 22 & 95,3 & 53,7 & 85,9 & 85,3 & 106 \\
\hline Cristina Jer"nimo & AEB conj & $\mathrm{F}$ & 112 & 123 & 11 & 86,4 & 45,2 & 80,3 & 77,3 & 93,5 \\
\hline Daniel A, Calze & AEB conj & $\bar{M}$ & 116 & 131 & 15 & 81,9 & 48,8 & 81,2 & 72,5 & 96,9 \\
\hline Daniel A, Furlane & AEB conj & M & 130 & 143 & 13 & 89,6 & 52,2 & 83,2 & 80,2 & 106,2 \\
\hline Glaucia Rodrigher & AEB conj & $\mathrm{F}$ & 87 & 111 & 24 & 92,2 & 46,6 & 74,1 & 82,8 & 89,8 \\
\hline Gustavo F, Bizarr & AEB conj & $\mathrm{M}$ & 110 & 127 & 17 & 86,1 & 49,1 & 81 & 80,5 & 102,9 \\
\hline Israel L, Mufalo & AEB conj & $\mathrm{M}$ & 108 & 117 & 9 & 89,9 & 51,3 & 81,7 & 82,1 & 98,2 \\
\hline Jorge A, Bosolim & AEB conj & M & 107 & 115 & 8 & 84,3 & 50,1 & 82,5 & 76,7 & 99,1 \\
\hline Juliana B, de God & AEB conj & $\mathrm{F}$ & 108 & 117 & 9 & 79,9 & 47,1 & 79,1 & 74,1 & 97,3 \\
\hline Leandro Holgado & AEB conj & $\bar{M}$ & 126 & 139 & 13 & 89,2 & 49,1 & 81,4 & 78,2 & 96,7 \\
\hline Leandro R, Ferrar & AEB conj & M & 117 & 153 & 36 & 86,7 & 47 & 75,5 & 78,7 & 97,2 \\
\hline Murilo de $\mathrm{O}$, Barr & AEB conj & M & 138 & 150 & 12 & 83,1 & 46,2 & 82,5 & 76,6 & 97,9 \\
\hline Nat lia & AEB conj & $\mathrm{F}$ & 106 & 119 & 13 & 84,4 & 47,3 & 76,7 & 77,7 & 96 \\
\hline Paula Bush & AEB conj & $\mathrm{F}$ & 120 & 135 & 15 & 86 & 45,4 & 76,7 & 78,3 & 98,2 \\
\hline Paula R, Secco & AEB conj & $\mathrm{F}$ & 108 & 117 & 9 & 81,2 & 45,3 & 73,7 & 71,9 & 88,9 \\
\hline Paulo de Tarso & AEB conj & M & 135 & 162 & 27 & 83,5 & 50,5 & 87,4 & 76,2 & 111,4 \\
\hline Priscila & AEB conj & $\mathrm{F}$ & 108 & 124 & 16 & 86,2 & 52,4 & 83,6 & 79,2 & 104,3 \\
\hline Rodrigo Magri & AEB conj & $\mathrm{M}$ & 144 & 164 & 20 & 81,1 & 51,5 & 85,6 & 76,2 & 104,1 \\
\hline Talita C, Bamichi & AEB conj & $\mathrm{F}$ & 128 & 143 & 15 & 87,1 & 44,3 & 80,4 & 81,3 & 99,1 \\
\hline Thiago Concer & AEB conj & $\mathrm{M}$ & 112 & 127 & 15 & 83,5 & 49 & 88,1 & 78,8 & 115,1 \\
\hline Vera L£cia Santan & AEB conj & $F$ & 94 & 138 & 44 & 81,3 & 45,4 & 73,8 & 74 & 89,6 \\
\hline Ang,lica G, Ribei & AEB IHG & $\mathrm{F}$ & 150 & 165 & 15 & 82,9 & 49,6 & 83,9 & 77,3 & 109 \\
\hline Atila Mariano & AEB IHG & $\bar{M}$ & 144 & 156 & 12 & 79,1 & 51 & 87 & 73,7 & 113,2 \\
\hline Bianca Silva & AEB IHG & $\mathrm{F}$ & 132 & 149 & 17 & 92,2 & 53,8 & 91 & 78,2 & 107,8 \\
\hline Caio Garcia & AEB IHG & $\mathrm{M}$ & 132 & 142 & 10 & 86,2 & 52,5 & 83,4 & 77,1 & 101,8 \\
\hline Carlos Carnevale & AEB IHG & M & 132 & 151 & 19 & 82,9 & 49,4 & 83,9 & 72,9 & 104,2 \\
\hline David Silva & AEB IHG & $\mathrm{M}$ & 120 & 145 & 25 & 79,7 & 46,6 & 77,2 & 74,2 & 101,7 \\
\hline D,bora Silva & AEB IHG & $\mathrm{F}$ & 127 & 142 & 15 & 84,3 & 48,5 & 80,2 & 71,4 & 94,1 \\
\hline Elizabeth Silva & AEB IHG & $\mathrm{F}$ & 133 & 146 & 13 & 81,1 & 49,7 & 83,5 & 72,2 & 99,9 \\
\hline Fernanda Santos & AEB IHG & $\mathrm{F}$ & 130 & 134 & 4 & 85,1 & 47,3 & 78,6 & 79,2 & 102,2 \\
\hline Fernando Leandro & AEB IHG & $\bar{M}$ & 156 & 168 & 12 & 80,5 & 51,5 & 86,1 & 73,9 & 110 \\
\hline Flavia Menes & AEB IHG & $\mathrm{F}$ & 120 & 143 & 23 & 80,1 & 46,9 & 80,8 & 75 & 100,4 \\
\hline Graziela Munhoz & AEB IHG & $\mathrm{F}$ & 101 & 119 & 18 & 86,9 & 46 & 77,9 & 78,7 & 90,2 \\
\hline Jonatas Cossonich & AEB IHG & M & 102 & 120 & 18 & 80,9 & 46,1 & 77,4 & 73,6 & 95,7 \\
\hline Jorge JEnior & AEB IHG & $\mathrm{M}$ & 122 & 138 & 16 & 83,7 & 49,7 & 82 & 77 & 108,2 \\
\hline Jowatas Cossonich & AEB IHG & M & 102 & 120 & 18 & 80,4 & 50,2 & 81,3 & 72,4 & 97,9 \\
\hline Lais Y, Zuciari & AEB IHG & $\mathrm{F}$ & 127 & 148 & 21 & 82,5 & 48,2 & 78 & 75,6 & 97,9 \\
\hline Leonardo Nogueira & AEB IHG & $\bar{M}$ & 120 & 144 & 24 & 81,7 & 49 & 80,7 & 75,9 & 99,9 \\
\hline Marco Garcia & AEB IHG & $\mathrm{M}$ & 132 & 156 & 24 & 77,9 & 46 & 84,9 & 72,3 & 105,6 \\
\hline Murilo Silva & AEB IHG & M & 150 & 161 & 11 & 80,1 & 50,2 & 85,3 & 75,4 & 102 \\
\hline Nayla Melhem & AEB IHG & $\mathrm{F}$ & 115 & 134 & 19 & 91,3 & 50,5 & 80,7 & 80,1 & 100,8 \\
\hline Patricia Pereira & AEB IHG & $\mathrm{F}$ & 120 & 132 & 12 & 81,5 & 44,3 & 75,7 & 75,3 & 93,2 \\
\hline Paula Soares & AEB IHG & $\mathrm{F}$ & 112 & 129 & 17 & 82,2 & 46,8 & 81,5 & 71,3 & 98 \\
\hline Samuel Goncalves & AEB IHG & M & 120 & 132 & 12 & 81,6 & 45,3 & 76,5 & 73,9 & 94,2 \\
\hline Thalita Ferreira & AEB IHG & $\mathrm{F}$ & 123 & 133 & 10 & 86,1 & 47,5 & 77,5 & 77,6 & 99,4 \\
\hline Willian G, M,Lope & AEB IHG & $\mathrm{M}$ & 132 & 144 & 12 & 86,2 & 52,4 & 84 & 79,1 & 103 \\
\hline
\end{tabular}


Apêndice 153

\begin{tabular}{|c|c|c|c|c|c|c|c|c|c|c|}
\hline Pacientes & Grupo & Gênero & Idade I & Idade F & Tempo & SNA i & fhp-A i & $\mathrm{CoA} \mathrm{i}$ & SNB i & CoGn i \\
\hline Alexandre G, Mend & Controle & $\mathrm{M}$ & 126 & 150 & 24 & 81,5 & 47,4 & 80,5 & 76,8 & 105,8 \\
\hline Carla F, Z, Soare & Controle & $\mathrm{F}$ & 120 & 133 & 13 & 87,6 & 49,1 & 80,8 & 81,3 & 100 \\
\hline Denis C, Fileti & Controle & $M$ & 140 & 155 & 15 & 85 & 48,4 & 81,2 & 78,6 & 100,4 \\
\hline Fabiana Buzalaf & Controle & $\mathrm{F}$ & 126 & 138 & 12 & 80,7 & 48,4 & 76,3 & 74,4 & 95,4 \\
\hline Flaviana Andrade & Controle & $\mathrm{F}$ & 113 & 136 & 23 & 85,6 & 48,5 & 80,2 & 81,8 & 106,5 \\
\hline Jos, A, de A,Card & Controle & M & 129 & 144 & 15 & 83 & 52,6 & 89,1 & 75,4 & 106 \\
\hline Lucas de $R, P$, Co & Controle & $\mathrm{M}$ & 127 & 144 & 17 & 79,2 & 46,4 & 77,1 & 75,3 & 97,2 \\
\hline Marcelo Ticianeli & Controle & $M$ & 128 & 140 & 12 & 79,9 & 49,7 & 83,9 & 76,9 & 103,8 \\
\hline Mirela Guareschi & Controle & $\mathrm{F}$ & 106 & 132 & 26 & 78,9 & 44,3 & 77,2 & 72,7 & 95,9 \\
\hline Nat lia B, Fonsat & Controle & $\mathrm{F}$ & 108 & 122 & 14 & 83,5 & 46,6 & 78,9 & 81,8 & 98,9 \\
\hline Plinio B Jr & Controle & $\mathrm{M}$ & 131 & 144 & 13 & 77,4 & 49,8 & 77,9 & 73,5 & 100,6 \\
\hline Rafael G, Sanches & Controle & $\mathrm{M}$ & 124 & 138 & 14 & 80,5 & 49,8 & 81,9 & 75,1 & 102 \\
\hline Rodrigo Andrade & Controle & $M$ & 126 & 138 & 12 & 82,7 & 54,4 & 89,3 & 76,4 & 104,6 \\
\hline Rodrigo Bueno & Controle & M & 115 & 129 & 14 & 79,5 & 45,5 & 77,9 & 76,2 & 99,4 \\
\hline Rog,rio G, Vilela & Controle & $\mathrm{M}$ & 120 & 134 & 14 & 80 & 51,6 & 84,3 & 72,6 & 98,2 \\
\hline Rosemeire Simonet & Controle & $F$ & 100 & 136 & 36 & 81,7 & 45,2 & 74,5 & 76,7 & 91,6 \\
\hline Thays Damaceno & Controle & $\mathrm{F}$ & 122 & 131 & 9 & 81 & 45,1 & 71,4 & 74,1 & 87,7 \\
\hline Thais Freire & Controle & $\mathrm{F}$ & 100 & 114 & 14 & 80,6 & 45,4 & 77,2 & 77,3 & 95,7 \\
\hline Thelma C, Cozza & Controle & $\mathrm{F}$ & 126 & 139 & 13 & 82,6 & 45,4 & 78,7 & 78,5 & 99,3 \\
\hline
\end{tabular}


Apêndice 154

\begin{tabular}{|c|c|c|c|c|c|c|c|c|c|c|}
\hline Pacientes & Grupo & ANB i & AFAI i & $\begin{array}{c}\text { SN,GoMe } \\
\text { i }\end{array}$ & $\begin{array}{c}\text { SNPP } \\
\mathrm{i}\end{array}$ & $\begin{array}{c}\text { Frank- } \\
\text { Plo i }\end{array}$ & $\begin{array}{c}\text { PP- } \\
\text { GoMe i }\end{array}$ & $\begin{array}{c}\text { FrankGoMe } \\
\mathrm{i}\end{array}$ & $\begin{array}{c}\text { ArGo,GoMe } \\
i\end{array}$ & $1, \mathrm{NA} \mathrm{i}$ \\
\hline Amanda M, Caredo & AEB conj & 8,6 & 59,3 & 31,5 & 2,2 & 3 & 29,3 & 26,4 & 47 & 26,7 \\
\hline Ana Cl udia Andre & AEB conj & 1,6 & 64,2 & 38,3 & 4,5 & 2,3 & 33,8 & 31,5 & 50,4 & 38,1 \\
\hline Ana Paula Rodrigh & AEB conj & 7,2 & 51 & 29,9 & 5,1 & 6,9 & 24,8 & 17,9 & 58,8 & 11,5 \\
\hline Andre Luis Gimene & AEB conj & 6,4 & 58,8 & 37 & 6,6 & 1,6 & 30,5 & 28,9 & 49,6 & 26,3 \\
\hline Carlos E, Cordeir & AEB conj & 10 & 66,3 & 37 & 1,3 & 3,7 & 35,7 & 32 & 38,5 & 23,7 \\
\hline Cristina Jer"nimo & AEB conj & 9,1 & 56,2 & 33,9 & 8,3 & $-1,7$ & 25,6 & 27,2 & 47,9 & 21,6 \\
\hline Daniel A, Calze & AEB conj & 9,4 & 59,2 & 39,8 & 10,1 & 0,5 & 29,7 & 29,2 & 49,4 & 27,9 \\
\hline Daniel A, Furlane & AEB conj & 9,4 & 68,1 & 39 & 1,8 & 8 & 37,2 & 29,2 & 46,8 & 27,7 \\
\hline Glaucia Rodrigher & AEB conj & 9,3 & 50,6 & 28,4 & 5,8 & $-1,2$ & 22,6 & 23,9 & 53,5 & 16,7 \\
\hline Gustavo F, Bizarr & AEB conj & 5,5 & 56,4 & 37 & 6,8 & 0,2 & 30,2 & 30 & 40,2 & 28,3 \\
\hline Israel L, Mufalo & AEB conj & 7,8 & 57,7 & 33 & 4,9 & 4 & 28,1 & 24,1 & 52,1 & 34,2 \\
\hline Jorge A, Bosolim & AEB conj & 7,5 & 60,4 & 35,9 & 8,7 & 2,6 & 27,2 & 24,5 & 47,7 & 21,6 \\
\hline Juliana B, de God & AEB conj & 5,8 & 61,3 & 42 & 6,1 & 3,3 & 35,9 & 32,6 & 41,8 & 29,7 \\
\hline Leandro Holgado & AEB conj & 11 & 61,2 & 33,7 & 6,6 & 0,7 & 27,1 & 26,4 & 55,9 & 17,6 \\
\hline Leandro R, Ferrar & AEB conj & 8 & 58,8 & 34,1 & 7,8 & 2 & 26,3 & 24,3 & 57,9 & 32,4 \\
\hline Murilo de O, Barr & AEB conj & 6,5 & 56,8 & 32,9 & 6,4 & $-0,3$ & 26,5 & 26,8 & 47,5 & 26,5 \\
\hline Nat lia & AEB conj & 6,8 & 55,2 & 36,9 & 8,1 & 3,1 & 28,8 & 25,7 & 48,6 & 22,4 \\
\hline Paula Bush & AEB conj & 7,6 & 61,8 & 44,9 & 6,4 & 3,2 & 38,5 & 35,2 & 41,1 & 24,5 \\
\hline Paula R, Secco & AEB conj & 9,3 & 60,8 & 41,2 & 2,9 & 9,8 & 38,3 & 28,5 & 49,1 & 23,4 \\
\hline Paulo de Tarso & AEB conj & 7,3 & 72,8 & 42,5 & 6,4 & 1,7 & 36,1 & 34,4 & 43,3 & 19,8 \\
\hline Priscila & AEB conj & 7 & 60 & 31,7 & 3 & 7 & 28,7 & 21,6 & 54,1 & 28,2 \\
\hline Rodrigo Magri & AEB conj & 4,9 & 52,5 & 30,5 & 13 & $-5,6$ & 17,5 & 23,2 & 50,6 & 29,9 \\
\hline Talita C, Bamichi & AEB conj & 5,8 & 53,6 & 31,8 & 7,2 & $-0,4$ & 24,6 & 25 & 50,7 & 25,2 \\
\hline Thiago Concer & AEB conj & 4,7 & 72,3 & 39,8 & 6,3 & 0,8 & 33,5 & 32,7 & 45 & 24,8 \\
\hline Vera L£cia Santan & AEB conj & 7,3 & 55,6 & 40,3 & 8,9 & 2,8 & 31,4 & 28,6 & 42,5 & 22,7 \\
\hline Ang,lica G, Ribei & AEB IHG & 5,6 & 68,2 & 40,6 & 6,5 & $-0,6$ & 34,1 & 34,6 & 49,6 & 20,5 \\
\hline Atila Mariano & AEB IHG & 5,4 & 72,9 & 44,6 & 8,4 & 2,1 & 36,2 & 34,1 & 39,7 & 33,1 \\
\hline Bianca Silva & AEB IHG & 14 & 71,9 & 42,4 & 5,3 & 6 & 37,1 & 31,1 & 37,4 & 21,3 \\
\hline Caio Garcia & AEB IHG & 9,1 & 62,9 & 39,2 & 6,5 & 5,5 & 32,7 & 27,2 & 39,4 & 10,2 \\
\hline Carlos Carnevale & AEB IHG & 10 & 67,1 & 37,8 & 6,7 & 2,2 & 31,1 & 28,9 & 55,5 & 17,5 \\
\hline David Silva & AEB IHG & 5,5 & 64,4 & 42,1 & 5 & 7,6 & 37,1 & 29,6 & 47 & 33 \\
\hline D,bora Silva & AEB IHG & 13 & 65,5 & 44,9 & 6,3 & 4,5 & 38,7 & 34,2 & 44,8 & 16,9 \\
\hline Elizabeth Silva & AEB IHG & 8,9 & 64,6 & 39,4 & 9,8 & 5,2 & 29,6 & 24,3 & 51 & 11 \\
\hline Fernanda Santos & AEB IHG & 5,9 & 62,7 & 37,2 & 3,6 & 3,2 & 33,6 & 30,4 & 47,6 & 18,4 \\
\hline Fernando Leandro & AEB IHG & 6,6 & 71,9 & 43,3 & 9,4 & 2,8 & 33,9 & 31,1 & 50,1 & 20,7 \\
\hline Flavia Menes & AEB IHG & 5,1 & 61,5 & 45,4 & 9,5 & 2 & 35,9 & 33,9 & 36,9 & 21,5 \\
\hline Graziela Munhoz & AEB IHG & 8,2 & 55,7 & 33,9 & 2,6 & 4,1 & 31,3 & 27,2 & 42,2 & 30,2 \\
\hline Jonatas Cossonich & AEB IHG & 7,3 & 62,4 & 43,7 & 4,7 & 4,6 & 39 & 34,4 & 44,4 & 16,3 \\
\hline Jorge J£nior & AEB IHG & 6,7 & 76,1 & 44,2 & $-2,1$ & 10,2 & 46,3 & 36,1 & 41,1 & 23,1 \\
\hline Jowatas Cossonich & AEB IHG & 8 & 65,8 & 47,5 & 8 & 5 & 39,5 & 34,5 & 41 & 16,5 \\
\hline Lais Y, Zuciari & AEB IHG & 6,9 & 60,1 & 45,3 & 12,1 & -1 & 33,2 & 34,2 & 42,5 & 22,8 \\
\hline Leonardo Nogueira & AEB IHG & 5,8 & 60,5 & 35,1 & 5,4 & 6 & 29,7 & 23,7 & 50,1 & 23,8 \\
\hline Marco Garcia & AEB IHG & 5,6 & 66,6 & 48,6 & 13,7 & $-0,7$ & 34,9 & 35,6 & 35,8 & 22,2 \\
\hline Murilo Silva & AEB IHG & 4,7 & 61,6 & 34,8 & 6,6 & 2,6 & 28,2 & 25,6 & 46,5 & 27,9 \\
\hline Nayla Melhem & AEB IHG & 11,2 & 62,9 & 37,8 & 4,9 & 2,2 & 32,9 & 30,7 & 47,4 & 12,8 \\
\hline Patricia Pereira & AEB IHG & 6,2 & 57,5 & 38,5 & 11,1 & $-4,2$ & 27,4 & 31,6 & 46,2 & 24,4 \\
\hline Paula Soares & AEB IHG & 10,9 & 64,3 & 49,2 & 12,3 & 0,8 & 36,9 & 36,1 & 47,1 & 19,1 \\
\hline Samuel Goncalves & AEB IHG & 7,7 & 63,6 & 38,7 & 4,8 & 0,4 & 33,9 & 33,6 & 48,4 & 30,2 \\
\hline Thalita Ferreira & AEB IHG & 8,5 & 67,5 & 41,4 & 2,5 & 5,9 & 39 & 33 & 44,8 & 23,6 \\
\hline Willian G, M,Lope & AEB IHG & 7,1 & 59,3 & 32,8 & 2,7 & 4,5 & 30,1 & 25,6 & 45,9 & 20,2 \\
\hline
\end{tabular}


Apêndice 155

\begin{tabular}{|c|c|c|c|c|c|c|c|c|c|c|}
\hline Pacientes & Grupo & ANB i & AFAl i & $\begin{array}{c}\mathrm{SN}, \mathrm{GoMe} \\
\mathrm{i}\end{array}$ & SNPP i & $\begin{array}{l}\text { Frank- } \\
\text { Plo i }\end{array}$ & $\begin{array}{c}\text { PP- } \\
\text { GoMe i }\end{array}$ & $\begin{array}{c}\text { FrankGoMe } \\
\mathrm{i} \\
\end{array}$ & $\begin{array}{c}\text { ArGo,GoMe } \\
\mathrm{i} \\
\end{array}$ & $1, \mathrm{NA} \mathrm{i}$ \\
\hline Alexandre G, Mend & Controle & 4,7 & 66,3 & 41,3 & 4,7 & 1,4 & 36,6 & 35,2 & 45,9 & 35,4 \\
\hline Carla F, Z, Soare & Controle & 6,3 & 59,8 & 29,7 & 4,8 & $-0,1$ & 24,9 & 25 & 55,7 & 19,5 \\
\hline Denis C, Fileti & Controle & 6,4 & 61 & 34,3 & 4,6 & 2,2 & 29,7 & 27,5 & 48,3 & 26,9 \\
\hline Diego B, Vides & Controle & 5,5 & 61,6 & 29,5 & 2,8 & 3,4 & 26,7 & 23,3 & 46,9 & 20,1 \\
\hline Fabiana Buzalaf & Controle & 6,4 & 56,7 & 36,2 & 7 & 7 & 29,2 & 22,3 & 51,8 & 16,1 \\
\hline Flaviana Andrade & Controle & 3,9 & 64,9 & 36,5 & 3,5 & 3,6 & 33 & 29,4 & 46,5 & 15,8 \\
\hline Giedre R, Ponce & Controle & 3,8 & 49,2 & 27,8 & 9,9 & $-0,4$ & 17,9 & 18,3 & 53,8 & 25,1 \\
\hline Jaime $\mathrm{C}, \mathrm{M}, \mathrm{J} £$ nio & Controle & 5,2 & 60,6 & 32,9 & 2,6 & 2,7 & 30,3 & 27,6 & 50,8 & 17,2 \\
\hline Jos, A, de A,Card & Controle & 7,6 & 57,9 & 32,3 & 10,3 & $-3,1$ & 22 & 25,1 & 48,4 & 7 \\
\hline Lucas de $\mathrm{R}, \mathrm{P}, \mathrm{Co}$ & Controle & 3,9 & 56,4 & 32,7 & 2,3 & 7,3 & 30,4 & 23,1 & 49,1 & 27,7 \\
\hline Marcelo Ticianeli & Controle & 3 & 63,1 & 33,8 & 6,3 & 2,4 & 27,5 & 25 & 47,4 & 33 \\
\hline Mirela Guareschi & Controle & 6,1 & 61,8 & 37,4 & 7,6 & 3,5 & 29,7 & 26,2 & 60,7 & 20,1 \\
\hline Nat lia B, Fonsat & Controle & 1,7 & 53,3 & 28,8 & 6,9 & $-1,3$ & 21,8 & 23,2 & 48,2 & 35,9 \\
\hline Nat lia R, Tonett & Controle & 9,1 & 61,8 & 34 & 8,1 & $-2,6$ & 25,8 & 28,4 & 47,9 & 21,9 \\
\hline Osvaldo Cruz & Controle & 6,9 & 57,2 & 32,2 & 6 & 3 & 26,2 & 23,2 & 52 & 30,6 \\
\hline Patricia B, Medin & Controle & 5,4 & 58,7 & 30,7 & 7,5 & $-2,2$ & 23,2 & 25,3 & 50,3 & 18,8 \\
\hline Plinio B Jr & Controle & 3,8 & 57,3 & 41,3 & 10 & 6,4 & 31,3 & 24,9 & 47,7 & 24,3 \\
\hline Rafael G, Sanches & Controle & 5,4 & 59,6 & 35 & 9,6 & 2,7 & 25,4 & 22,7 & 50,1 & 29,3 \\
\hline Rodrigo Andrade & Controle & 6,3 & 61,2 & 35,2 & 9,4 & 2,4 & 25,8 & 23,5 & 44,2 & 17,2 \\
\hline Rodrigo Bueno & Controle & 3,2 & 58,9 & 33,7 & 8,3 & 0,7 & 25,4 & 24,7 & 53,5 & 27,3 \\
\hline Rog,rio G, Vilela & Controle & 7,4 & 60,2 & 32,9 & 6,1 & 3,2 & 26,8 & 23,5 & 52,3 & 24,4 \\
\hline Rosemeire Simonet & Controle & 5 & 55 & 37,9 & 8,7 & 1,2 & 29,3 & 28,1 & 49,8 & 16,1 \\
\hline Thays Damaceno & Controle & 6,9 & 53,8 & 34,8 & 6,2 & 5,3 & 28,6 & 23,3 & 51,7 & 16,1 \\
\hline Thais Freire & Controle & 3,4 & 50,8 & 36,2 & 8,2 & 5,1 & 27,9 & 22,8 & 47,2 & 26 \\
\hline Thelma C, Cozza & Controle & 4,1 & 59,3 & 32,4 & 2,2 & 3 & 30,3 & 27,3 & 46,9 & 26,6 \\
\hline
\end{tabular}




\begin{tabular}{|c|c|c|c|c|c|c|c|c|c|c|}
\hline Pacientes & Grupo & IS-PP i & $\begin{array}{c}\text { fhp- } \\
\text { distalU6 } \\
\mathrm{i}\end{array}$ & $\begin{array}{c}\text { Fhp- } \\
\text { ápice } \\
\text { U6 i }\end{array}$ & $\begin{array}{l}\text { Ms- } \\
\text { PP i }\end{array}$ & $\begin{array}{c}\text { Mi- } \\
\text { GoMe } \\
i\end{array}$ & $\begin{array}{c}\text { II- } \\
\text { GoMe i }\end{array}$ & $\underset{\mathrm{i}}{\text { Nasolabial }}$ & Li-E i & LS-E i \\
\hline Amanda $\mathrm{M}$, Caredo & AEB conj & 23,7 & 8,7 & 20,4 & 19 & 26 & 33,1 & 119,6 & $-3,1$ & $-1,2$ \\
\hline Ana $\mathrm{Cl}$ udia Andre & AEB conj & 26,8 & 9 & 21,7 & 20,9 & 26,6 & 41,1 & 116,1 & $-1,4$ & $-0,9$ \\
\hline Ana Paula Rodrigh & AEB conj & 22,7 & 11,5 & 23,7 & 16,4 & 24,3 & 33,3 & 113,5 & $-0,4$ & 0,5 \\
\hline Andre Luis Gimene & AEB conj & 25,5 & 9 & 21,5 & 18 & 24,5 & 37,5 & 105 & 0,1 & $-0,2$ \\
\hline Carlos E, Cordeir & AEB conj & 26,2 & 17,9 & 28,7 & 20,5 & 28,9 & 41,3 & 108 & 5,3 & 3,4 \\
\hline Cristina Jer"nimo & AEB conj & 25,6 & 7,2 & 20,4 & 16,7 & 26,9 & 35,3 & 102 & 4,6 & 2,7 \\
\hline Daniel A, Calze & AEB conj & 25,5 & 11,3 & 23,5 & 20,4 & 24 & 35,6 & 100 & 0,5 & 1,4 \\
\hline Daniel A, Furlane & AEB conj & 28,7 & 14,7 & 24,3 & 21,6 & 28,2 & 38,6 & 103,1 & 2,2 & 0,9 \\
\hline Glaucia Rodrigher & AEB conj & 16,7 & 10,8 & 24,5 & 16,5 & 23,6 & 29,2 & 113,6 & 0,7 & 0 \\
\hline Gustavo F, Bizarr & AEB conj & 22,8 & 13,3 & 24,3 & 17,5 & 25 & 37,3 & 123,6 & 2,1 & $-1,9$ \\
\hline Israel L, Mufalo & AEB conj & 23,1 & 13 & 23,9 & 17,6 & 25,2 & 35,4 & 125,3 & 2,8 & 0,8 \\
\hline Jorge A, Bosolim & AEB conj & 23 & 9,3 & 20,9 & 18,5 & 26,6 & 34,3 & 118,1 & 1,2 & 1,5 \\
\hline Juliana B, de God & AEB conj & 27,5 & 8,4 & 20,2 & 20,7 & 21,5 & 37,9 & 102,1 & 3,8 & 1,8 \\
\hline Leandro Holgado & AEB conj & 26,7 & 9,9 & 22,3 & 19,9 & 26,7 & 37,3 & 140,8 & 3,2 & 3,5 \\
\hline Leandro R, Ferrar & AEB conj & 24 & 11,3 & 23,1 & 20,1 & 26,5 & 38,7 & 82,8 & 1,7 & 3,7 \\
\hline Murilo de O, Barr & AEB conj & 25 & 8,1 & 20,8 & 20,1 & 23,1 & 36,2 & 111,1 & $-1,5$ & 0,1 \\
\hline Nat lia & AEB conj & 22,9 & 11,6 & 23,4 & 17,8 & 23,4 & 32,5 & 126,4 & 0,2 & 1,1 \\
\hline Paula Bush & AEB conj & 27,1 & 12,3 & 23,7 & 20,7 & 25,2 & 39,9 & 125,8 & 3,7 & 3,9 \\
\hline Paula R, Secco & AEB conj & 25,7 & 10,8 & 20,7 & 18,7 & 24,3 & 36,5 & 117,6 & 2,2 & 2,7 \\
\hline Paulo de Tarso & AEB conj & 33,1 & 13,5 & 25,6 & 23,9 & 32,1 & 47 & 106,8 & 6,2 & 3,3 \\
\hline Priscila & AEB conj & 25,2 & 16,7 & 29 & 20,2 & 26,3 & 36,1 & 110,4 & 1,4 & 2,1 \\
\hline Rodrigo Magri & AEB conj & 21,4 & 13,6 & 24,8 & 20,5 & 24 & 36,9 & 110,1 & $-1,8$ & 0,7 \\
\hline Talita C, Bamichi & AEB conj & 22 & 8,1 & 20,4 & 18,7 & 23,9 & 33,1 & 126,2 & $-2,6$ & $-2,6$ \\
\hline Thiago Concer & AEB conj & 30,3 & 13,4 & 25,3 & 24,5 & 31,2 & 42,7 & 131,5 & $-0,4$ & $-1,5$ \\
\hline Vera LEcia Santan & AEB conj & 19,6 & 10,1 & 22 & 15,7 & 25,6 & 33,8 & 132,6 & $-1,9$ & $-0,7$ \\
\hline Ang,lica G, Ribei & AEB IHG & 27,6 & 15,4 & 27,3 & 22,3 & 29,9 & 42,1 & 101,8 & -1 & $-2,5$ \\
\hline Atila Mariano & AEB IHG & 31,4 & 15,4 & 25,5 & 25,5 & 29,3 & 43,9 & 115,7 & 3,3 & $-0,6$ \\
\hline Bianca Silva & AEB IHG & 30 & 17,9 & 29 & 21,5 & 32,9 & 43,6 & 91,6 & 4 & 5,2 \\
\hline Caio Garcia & AEB IHG & 28,3 & 16,6 & 27,8 & 20,3 & 25,7 & 37 & 104,1 & 2,1 & 0,7 \\
\hline Carlos Carnevale & AEB IHG & 29,1 & 7,9 & 20,6 & 20,4 & 28,6 & 41,2 & 115 & 2,4 & $-1,1$ \\
\hline David Silva & AEB IHG & 29 & 12,1 & 24,7 & 19,7 & 25,8 & 39,1 & 103,1 & 1,3 & 2,9 \\
\hline D,bora Silva & AEB IHG & 29,1 & 10,8 & 24 & 18,9 & 27,2 & 41,7 & 119,9 & 4,8 & 3,7 \\
\hline Elizabeth Silva & AEB IHG & 29,4 & 12,3 & 23,4 & 21,4 & 27,3 & 38 & 104,8 & 2,3 & $-0,4$ \\
\hline Fernanda Santos & AEB IHG & 28,6 & 14,2 & 24,7 & 20,1 & 27,1 & 38,7 & 100 & 2,7 & 1,3 \\
\hline Fernando Leandro & AEB IHG & 31,7 & 16,3 & 26,9 & 23,8 & 31,7 & 45,8 & 97,5 & 4,1 & 1,8 \\
\hline Flavia Menes & AEB IHG & 28,9 & 14,1 & 26,4 & 21,1 & 24,5 & 36,9 & 129,5 & 0,3 & $-2,6$ \\
\hline Graziela Munhoz & AEB IHG & 24,9 & 7,2 & 17,9 & 17,5 & 21,9 & 34,5 & 111,9 & 0,5 & 0,5 \\
\hline Jonatas Cossonich & AEB IHG & 27,8 & 9,2 & 20,7 & 17 & 25,4 & 37,5 & 96,8 & 5,5 & 4,3 \\
\hline Jorge JEnior & AEB IHG & 33,5 & 13,4 & 24,3 & 22,8 & 29,5 & 45 & 96,4 & 2,6 & 2,2 \\
\hline Jowatas Cossonich & AEB IHG & 29,3 & 11,5 & 24,2 & 19,7 & 25,8 & 38,7 & 93,4 & 5 & 3,4 \\
\hline Lais Y, Zuciari & AEB IHG & 25,9 & 12,9 & 24,9 & 21,7 & 23,6 & 38,6 & 105,3 & 3,7 & 1,5 \\
\hline Leonardo Nogueira & AEB IHG & 24,8 & 11 & 22 & 18,3 & 26,7 & 36,2 & 113,9 & 1,9 & 1,2 \\
\hline Marco Garcia & AEB IHG & 29,2 & 13,5 & 23,7 & 21,4 & 30,2 & 42,2 & 109,9 & 5,1 & 1,7 \\
\hline Murilo Silva & AEB IHG & 28,6 & 15,1 & 27,2 & 22,1 & 27,3 & 39,3 & 109,3 & 0,8 & 0,5 \\
\hline Nayla Melhem & AEB IHG & 28,2 & 13,5 & 24,8 & 19,4 & 26,5 & 39 & 110 & 2,2 & 0,8 \\
\hline Patricia Pereira & AEB IHG & 24,6 & 9,4 & 21,9 & 17,6 & 26,4 & 37,7 & 99,6 & $-0,5$ & $-0,1$ \\
\hline Paula Soares & AEB IHG & 27,8 & 10,5 & 21,6 & 19,1 & 27,8 & 40,4 & 109,5 & 6,4 & 4,1 \\
\hline Samuel Goncalves & AEB IHG & 25,9 & 6 & 19,9 & 21,7 & 24,1 & 37,5 & 113,5 & 4,1 & 1,4 \\
\hline Thalita Ferreira & AEB IHG & 26,6 & 11,2 & 22,2 & 20,1 & 27 & 39 & 121,5 & 1,6 & 0 \\
\hline Willian G, M,Lope & AEB IHG & 26 & 16,8 & 27,2 & 18,2 & 26,7 & 38,1 & 100 & 3,2 & 1,3 \\
\hline
\end{tabular}


Apêndice 157

\begin{tabular}{|c|c|c|c|c|c|c|c|c|c|c|}
\hline Pacientes & Grupo & IS-PP i & $\begin{array}{c}\text { fhp- } \\
\text { distalU6 } \\
\mathrm{i}\end{array}$ & $\begin{array}{l}\text { Fhp- } \\
\text { ápice } \\
\text { U6 i }\end{array}$ & $\begin{array}{l}\text { Ms- } \\
\text { PP i }\end{array}$ & $\begin{array}{c}\text { Mi- } \\
\text { GoMe } \\
i\end{array}$ & $\begin{array}{c}\text { II- } \\
\text { GoMe i }\end{array}$ & $\begin{array}{c}\text { Nasolabial } \\
\text { i }\end{array}$ & Li-E i & LS-E i \\
\hline Alexandre G, Mend & Controle & 26 & 11,2 & 23,6 & 18,8 & 29,5 & 42,8 & 103 & $-2,7$ & $-1,9$ \\
\hline Denis C, Fileti & Controle & 27 & 13,2 & 24,2 & 19,6 & 27,3 & 39,3 & 87,1 & 2,7 & $-0,1$ \\
\hline Diego B, Vides & Controle & 28 & 17,2 & 29,7 & 22,5 & 26,9 & 38,8 & 110,4 & $-2,1$ & $-1,1$ \\
\hline Fabiana Buzalaf & Controle & 25,5 & 15,4 & 25,5 & 16,7 & 26,9 & 34,7 & 120,2 & $-0,4$ & $-1,2$ \\
\hline Giedre R, Ponce & Controle & 20,8 & 14,5 & 24,3 & 16,6 & 24,8 & 31,3 & 108,9 & $-1,9$ & $-2,4$ \\
\hline Jaime $\mathrm{C}, \mathrm{M}, \mathrm{J} £$ nio & Controle & 26,6 & 8 & 19,7 & 18 & 26,6 & 35,5 & 116,7 & $-2,5$ & -2 \\
\hline Jos, A, de A,Card & Controle & 26,6 & 12,3 & 24,5 & 19,2 & 27,2 & 38,1 & 125,2 & $-0,9$ & $-2,8$ \\
\hline Lucas de R, P, Co & Controle & 26 & 13,2 & 23,8 & 19 & 23,2 & 32,7 & 106 & 0,6 & 0,3 \\
\hline Marcelo Ticianeli & Controle & 27,4 & 16,9 & 29,7 & 23,2 & 27 & 41 & 125,4 & 2,1 & 1,3 \\
\hline Patricia B, Medin & Controle & 27,1 & 12,5 & 24,4 & 19,6 & 27,2 & 36,9 & 113,3 & -4 & $-4,7$ \\
\hline Plinio B Jr & Controle & 24,9 & 16,1 & 24,9 & 17,9 & 24,8 & 37,4 & 123,8 & $-0,1$ & $-2,4$ \\
\hline Rafael G, Sanches & Controle & 25,5 & 13,9 & 24,8 & 19,6 & 27,9 & 36,8 & 123,5 & $-2,6$ & $-3,2$ \\
\hline Rodrigo Andrade & Controle & 28,8 & 15,1 & 24,4 & 18,9 & 28,2 & 37,6 & 119,1 & 3 & 1,6 \\
\hline Rodrigo Bueno & Controle & 25,7 & 8,9 & 20,1 & 20,1 & 26,8 & 36,7 & 119,2 & $-1,1$ & $-3,8$ \\
\hline Rog,rio G, Vilela & Controle & 27,2 & 16,3 & 26,7 & 19,8 & 28,2 & 38,1 & 123,9 & 4 & 2,6 \\
\hline Rosemeire Simonet & Controle & 21,5 & 8,9 & 20 & 17 & 24 & 33,6 & 119,1 & $-3,4$ & $-1,7$ \\
\hline Thays Damaceno & Controle & 24,6 & 13,6 & 25,6 & 19,2 & 24,4 & 33,4 & 121,3 & -4 & -5 \\
\hline Thais Freire & Controle & 21,9 & 13,3 & 24 & 15,7 & 22,8 & 32,1 & 104 & $-2,2$ & $-1,8$ \\
\hline Thelma C, Cozza & Controle & 25 & 8 & 19,7 & 17,2 & 26,3 & 38,4 & 120 & $-1,1$ & $-3,7$ \\
\hline
\end{tabular}


APÊNDICE 2 - Valores finais de todas as variáveis dos três grupos.

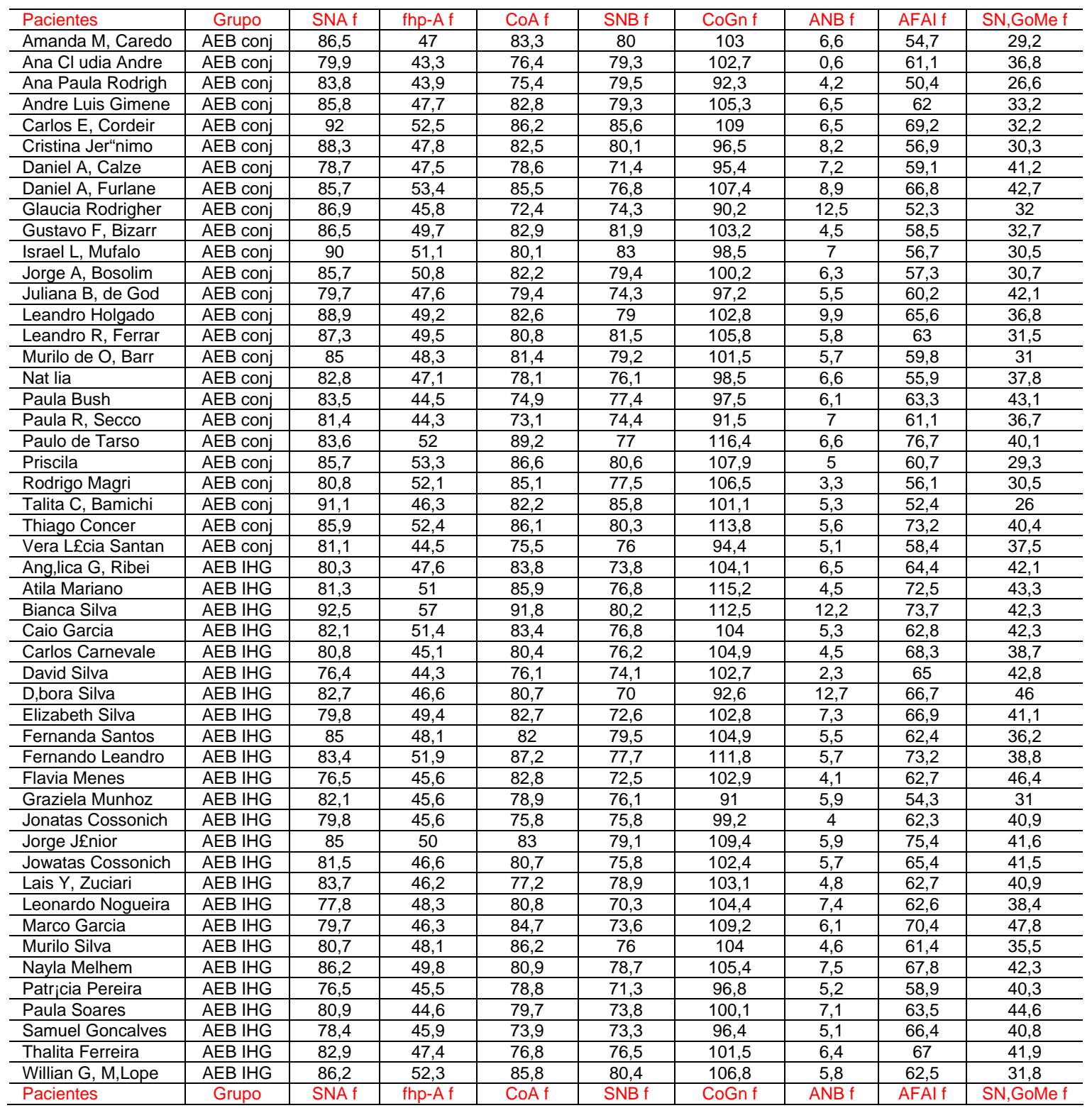


Apêndice 159

\begin{tabular}{|c|c|c|c|c|c|c|c|c|c|}
\hline Pacientes & Grupo & SNA f & fhp-A f & CoA f & SNB f & CoGn f & ANB $f$ & AFAl f & $\underset{f}{\text { SN, GoMe }}$ \\
\hline Alexandre G, Mend & Controle & 82 & 51,6 & 84,3 & 77,2 & 110,6 & 4,7 & 67,4 & 39,8 \\
\hline Carla F, Z, Soare & Controle & 88,5 & 51 & 82,8 & 82,2 & 101 & 6,3 & 58,7 & 27,1 \\
\hline Denis C, Fileti & Controle & 84,6 & 49,9 & 81,9 & 78 & 100,4 & 6,6 & 60 & 34,3 \\
\hline Diego B, Vides & Controle & 85,2 & 54,3 & 89,9 & 81,2 & 111,8 & 4 & 61,8 & 28 \\
\hline Fabiana Buzalaf & Controle & 78 & 49,1 & 79 & 73,8 & 98,4 & 4,2 & 55,7 & 36,1 \\
\hline Flaviana Andrade & Controle & 81,9 & 52,5 & 85,7 & 75,5 & 107,4 & 6,4 & 65,7 & 40,8 \\
\hline Giedre R, Ponce & Controle & 82,9 & 48,8 & 81,8 & 79,8 & 101,1 & 3 & 51,4 & 26,7 \\
\hline Jaime C, M, J£nio & Controle & 83,3 & 50,5 & 87,6 & 79,5 & 107,3 & 3,8 & 59,4 & 33 \\
\hline Jos, A, de A,Card & Controle & 83,3 & 53,1 & 91 & 76,9 & 109,4 & 6,4 & 59 & 31,3 \\
\hline Lucas de $\mathrm{R}, \mathrm{P}, \mathrm{Co}$ & Controle & 77,8 & 46,7 & 77,7 & 75,8 & 100,8 & 2 & 56,8 & 33,8 \\
\hline Marcelo Ticianeli & Controle & 83,3 & 53,4 & 88,2 & 76,3 & 106,5 & 7 & 64,7 & 35,3 \\
\hline Mirela Guareschi & Controle & 78,7 & 45,5 & 79,3 & 73,3 & 100,3 & 5,4 & 63,6 & 36,9 \\
\hline Nat lia B, Fonsat & Controle & 86,4 & 48,4 & 80,3 & 84,2 & 103,1 & 2,2 & 54,6 & 25 \\
\hline Nat lia R, Tonett & Controle & 88,9 & 50,1 & 85,3 & 81,3 & 105,8 & 7,6 & 64,3 & 31,4 \\
\hline Osvaldo Cruz & Controle & 75,9 & 44,8 & 85 & 70,5 & 101,7 & 5,4 & 58,5 & 31,4 \\
\hline Patricia B, Medin & Controle & 82,1 & 52,2 & 90,2 & 78,6 & 110 & 3,6 & 61,4 & 32,8 \\
\hline Plinio B Jr & Controle & 78 & 51,2 & 84 & 74,3 & 107,5 & 3,7 & 60 & 37,9 \\
\hline Rafael G, Sanches & Controle & 79,6 & 55,1 & 88,6 & 73,6 & 106,9 & 6,1 & 61 & 34,9 \\
\hline Rodrigo Andrade & Controle & 82,7 & 52,5 & 88,1 & 77,4 & 105,4 & 5,2 & 61,3 & 35 \\
\hline Rodrigo Bueno & Controle & 82,1 & 48,5 & 79,6 & 78,1 & 99 & 4 & 58,9 & 31,8 \\
\hline Rog,rio G, Vilela & Controle & 80,3 & 53,3 & 88,4 & 74,1 & 105 & 6,2 & 63,2 & 31 \\
\hline Rosemeire Simonet & Controle & 80,2 & 45,8 & 76,5 & 75,1 & 92,9 & 5,1 & 52,2 & 36,3 \\
\hline Thays Damaceno & Controle & 83,7 & 45,5 & 75,8 & 75,9 & 92,8 & 7,7 & 58,1 & 35,6 \\
\hline Thais Freire & Controle & 83,3 & 48,9 & 81,7 & 79,6 & 102,2 & 3,7 & 53,8 & 32,6 \\
\hline Thelma C, Cozza & Controle & 81 & 47,4 & 84 & 78 & 105,6 & 3 & 62 & 30,2 \\
\hline
\end{tabular}




\begin{tabular}{|c|c|c|c|c|c|c|c|c|c|}
\hline Pacientes & Grupo & SNPP f & $\begin{array}{l}\text { Frank- } \\
\text { Plo } f\end{array}$ & $\begin{array}{c}\text { PP- } \\
\text { GoMe f }\end{array}$ & $\begin{array}{c}\text { FrGoMe } \\
f\end{array}$ & $\begin{array}{l}\text { ArGo, } \\
\text { GoMe f }\end{array}$ & IS-PP f & $1, \mathrm{NA} \mathrm{f}$ & $\begin{array}{c}\text { fhp- } \\
\text { distalU6 } \\
f\end{array}$ \\
\hline Amanda M, Caredo & AEB conj & 6,8 & $-1,2$ & 22,3 & 23,5 & 51,7 & 22,4 & 11,6 & 9,6 \\
\hline Ana Cl udia Andre & AEB conj & 6,3 & 0,8 & 30,5 & 29,8 & 51,9 & 26,3 & 27,3 & 8 \\
\hline Ana Paula Rodrigh & AEB conj & 6,5 & 0,7 & 20,1 & 19,4 & 61,5 & 22,2 & 22,9 & 8 \\
\hline Andre Luis Gimene & AEB conj & 5,6 & -1 & 27,6 & 28,6 & 50,2 & 26,8 & 19,8 & 8 \\
\hline Carlos E, Cordeir & AEB conj & $-1,7$ & 5,1 & 33,9 & 28,8 & 38,6 & 28,1 & 25,4 & 14,1 \\
\hline Cristina Jer"nimo & AEB conj & 9,6 & $-5,3$ & 20,7 & 25,9 & 53,9 & 26 & 12,3 & 6,9 \\
\hline Daniel A, Calze & AEB conj & 14,5 & $-4,8$ & 26,6 & 31,4 & 46,1 & 26,2 & 14,3 & 5,7 \\
\hline Daniel A, Furlane & AEB conj & 8,8 & 5,4 & 34 & 28,6 & 46,8 & 26,7 & 15,1 & 11 \\
\hline Glaucia Rodrigher & AEB conj & 7,1 & 2,8 & 24,9 & 22,1 & 53,8 & 19,9 & 7,9 & 9 \\
\hline Gustavo F, Bizarr & AEB conj & 2,6 & $-0,4$ & 30,1 & 30,5 & 40,1 & 23,3 & 26,1 & 9,9 \\
\hline Israel L, Mufalo & AEB conj & 4,4 & 0,7 & 26,1 & 25,5 & 52,6 & 24,7 & 22,8 & 12,5 \\
\hline Jorge A, Bosolim & AEB conj & 9,3 & $-3,5$ & 21,5 & 24,9 & 54,8 & 20,2 & 27,9 & 9,9 \\
\hline Juliana B, de God & AEB conj & 6,8 & 3 & 35,3 & 32,3 & 37,8 & 25,6 & 29,8 & 7,8 \\
\hline Leandro Holgado & AEB conj & 7,4 & 0,8 & 29,5 & 28,6 & 51,9 & 28,7 & 12,3 & 9,7 \\
\hline Leandro R, Ferrar & AEB conj & 2,5 & 4,2 & 29 & 24,7 & 54,1 & 27,2 & 34,3 & 13,2 \\
\hline Murilo de O, Barr & AEB conj & 4,6 & 0,2 & 26,4 & 26,2 & 49,7 & 26,1 & 20,3 & 7,9 \\
\hline Nat lia & AEB conj & 12,8 & $-2,2$ & 25 & 27,2 & 47,5 & 23,7 & 10,9 & 8,4 \\
\hline Paula Bush & AEB conj & 4,4 & 2,8 & 38,7 & 35,9 & 44,2 & 27,9 & 15,7 & 7,1 \\
\hline Paula R, Secco & AEB conj & $-0,3$ & 10,3 & 37 & 26,7 & 55 & 25,7 & 16,4 & 8,4 \\
\hline Paulo de Tarso & AEB conj & 7,7 & 1,1 & 32,4 & 31,3 & 46,8 & 32,2 & 21,5 & 14,5 \\
\hline Priscila & AEB conj & 4,2 & 3,5 & 25,1 & 21,6 & 55,5 & 27,5 & 15,9 & 15,4 \\
\hline Rodrigo Magri & AEB conj & 9,8 & $-3,4$ & 20,7 & 24,2 & 51,8 & 23,7 & 22,3 & 13,2 \\
\hline Talita C, Bamichi & AEB conj & 3,9 & $-0,1$ & 22,1 & 22,2 & 51,6 & 21,2 & 20,3 & 10,4 \\
\hline Thiago Concer & AEB conj & 4,1 & 3,4 & 36,4 & 33 & 40,5 & 31,2 & 20,5 & 16,1 \\
\hline Vera L£cia Santan & AEB conj & 10 & $-1,8$ & 27,5 & 29,3 & 52,5 & 22,6 & 27,8 & 7,3 \\
\hline Ang,lica G, Ribei & AEB IHG & 8,9 & $-1,1$ & 33,1 & 34,2 & 50,2 & 26,9 & 22,5 & 11,4 \\
\hline Atila Mariano & AEB IHG & 5,3 & $-0,8$ & 38 & 38,8 & 39,1 & 30,1 & 27 & 12,7 \\
\hline Bianca Silva & AEB IHG & 5,6 & 3,3 & 36,7 & 33,4 & 44,3 & 30,8 & 19,6 & 16,6 \\
\hline Caio Garcia & AEB IHG & 6,8 & 5,4 & 35,5 & 30,1 & 38,8 & 28,2 & 21,7 & 12,7 \\
\hline Carlos Carnevale & AEB IHG & 6,9 & 0,9 & 31,9 & 31 & 52,3 & 29,7 & 19,9 & 6,5 \\
\hline David Silva & AEB IHG & 5,3 & 5,5 & 37,5 & 32 & 46,1 & 29,8 & 29,8 & 11,1 \\
\hline D,bora Silva & AEB IHG & 6,9 & 1,8 & 39,1 & 37,3 & 44,5 & 29,3 & 17,2 & 6,8 \\
\hline Elizabeth Silva & AEB IHG & 10,1 & 4,2 & 31 & 26,7 & 55,4 & 29,2 & 10,9 & 10,9 \\
\hline Fernanda Santos & AEB IHG & 2,2 & 4,9 & 34 & 29,2 & 49 & 28,5 & 20,1 & 14 \\
\hline Fernando Leandro & AEB IHG & 3,9 & 2,1 & 34,9 & 32,8 & 50,5 & 30,9 & 25 & 11,6 \\
\hline Flavia Menes & AEB IHG & 13,7 & $-2,5$ & 32,7 & 35,2 & 45,1 & 29,1 & 19,4 & 6,2 \\
\hline Graziela Munhoz & AEB IHG & 5,9 & 0,9 & 25 & 24,1 & 45,6 & 24,4 & 33 & 5,8 \\
\hline Jonatas Cossonich & AEB IHG & 7,4 & 3 & 33,5 & 30,5 & 44,4 & 28,4 & 18,3 & 10,1 \\
\hline Jorge JEnior & AEB IHG & $-1,5$ & 9,1 & 43,1 & 33,9 & 40,7 & 34,1 & 23,3 & 13,1 \\
\hline Jowatas Cossonich & AEB IHG & 8,2 & 2,7 & 33,3 & 30,6 & 45,7 & 29,3 & 19,4 & 8,9 \\
\hline Lais Y, Zuciari & AEB IHG & 8,9 & $-2,9$ & 31,9 & 34,8 & 47,7 & 26,7 & 24,4 & 11,1 \\
\hline Leonardo Nogueira & AEB IHG & 8 & 5,2 & 30,4 & 25,2 & 53,8 & 27,7 & 25 & 12,1 \\
\hline Marco Garcia & AEB IHG & 10,2 & $-1,3$ & 37,6 & 38,9 & 34,8 & 30,7 & 30,9 & 14,4 \\
\hline Murilo Silva & AEB IHG & 4,4 & 2,9 & 31,1 & 28,3 & 46 & 29,5 & 28,9 & 12 \\
\hline Nayla Melhem & AEB IHG & 6,4 & 0,4 & 35,9 & 35,4 & 46,6 & 30,2 & 15,2 & 10,7 \\
\hline Patricia Pereira & AEB IHG & 15,8 & $-3,7$ & 24,5 & 28,2 & 53,2 & 24,6 & 25,9 & 8,7 \\
\hline Paula Soares & AEB IHG & 11,5 & $-1,8$ & 33,1 & 34,9 & 48,3 & 28,6 & 19,6 & 8,8 \\
\hline Samuel Goncalves & AEB IHG & 5,4 & 5,3 & 35,4 & 30,1 & 49,7 & 28,5 & 28,2 & 7,2 \\
\hline Thalita Ferreira & AEB IHG & 4,3 & 5,5 & 37,6 & 32,1 & 45 & 27,7 & 16,3 & 10,5 \\
\hline Willian G, M,Lope & AEB IHG & 4,8 & 0,1 & 27 & 26,9 & 44,3 & 26,3 & 19,4 & 13 \\
\hline
\end{tabular}


Apêndice161

\begin{tabular}{|c|c|c|c|c|c|c|c|c|c|}
\hline Pacientes & Grupo & SNPP f & $\begin{array}{l}\text { Frank- } \\
\text { Plo f }\end{array}$ & $\begin{array}{c}\text { PP- } \\
\text { GoMe f }\end{array}$ & $\begin{array}{c}\text { FrGoMe } \\
f\end{array}$ & $\begin{array}{l}\text { ArGo, } \\
\text { GoMe f }\end{array}$ & IS-PP f & $1, N A f$ & $\begin{array}{c}\text { fhp- } \\
\text { distalU6 } \\
\mathrm{f}\end{array}$ \\
\hline Alexandre G, Mend & Controle & 5,4 & 3,4 & 34,4 & 31,1 & 46,4 & 26,8 & 36,6 & 15,8 \\
\hline Carla F, Z, Soare & Controle & 6,6 & $-1,2$ & 20,5 & 21,7 & 58,3 & 25,3 & 19,7 & 14,6 \\
\hline Denis C, Fileti & Controle & 3,9 & 2,5 & 30,4 & 27,9 & 47,1 & 26,4 & 28,2 & 16,1 \\
\hline Diego B, Vides & Controle & 4 & 3 & 23,9 & 20,9 & 51,4 & 27,8 & 19 & 19,2 \\
\hline Fabiana Buzalaf & Controle & 10,1 & 3,1 & 26 & 22,9 & 51,2 & 25,4 & 22,3 & 12,7 \\
\hline Flaviana Andrade & Controle & 6,1 & 6,8 & 34,7 & 27,9 & 49,3 & 30,6 & 19 & 15,5 \\
\hline Giedre R, Ponce & Controle & 8,8 & $-3,3$ & 17,9 & 21,2 & 53,6 & 22 & 28,8 & 13,8 \\
\hline Jaime $\mathrm{C}, \mathrm{M}, \mathrm{J}$ Enio & Controle & 7,1 & $-0,9$ & 25,9 & 26,8 & 46,6 & 27,5 & 23 & 12,3 \\
\hline Jos, A, de A,Card & Controle & 11 & $-3,7$ & 20,3 & 23,9 & 49,9 & 26,6 & 9,9 & 12,9 \\
\hline Lucas de $R, P$, Co & Controle & 5,2 & 3,9 & 28,6 & 24,7 & 50,6 & 26,2 & 27 & 14,1 \\
\hline Marcelo Ticianeli & Controle & 9 & 0,1 & 26,3 & 26,2 & 49,8 & 26,1 & 20,1 & 15,7 \\
\hline Mirela Guareschi & Controle & 8,2 & 2,8 & 28,7 & 25,9 & 60,8 & 30,2 & 22,6 & 10,4 \\
\hline Nat lia B, Fonsat & Controle & 5,1 & 2,8 & 19,9 & 17,1 & 49,5 & 23,8 & 32,5 & 18 \\
\hline Nat lia R, Tonett & Controle & 5,1 & 0,1 & 26,2 & 26,1 & 46,8 & 26,8 & 23,1 & 16,1 \\
\hline Osvaldo Cruz & Controle & 8,7 & 0,4 & 22,7 & 22,3 & 52,6 & 27,3 & 25,7 & 3,5 \\
\hline Patricia B, Medin & Controle & 7,5 & 0 & 25,4 & 25,4 & 50,3 & 26,9 & 22,7 & 15,7 \\
\hline Plinio B Jr & Controle & 9 & 5,7 & 28,9 & 23,2 & 48,7 & 26,5 & 19,5 & 18,1 \\
\hline Rafael G, Sanches & Controle & 13,2 & 0,9 & 21,7 & 20,8 & 52,5 & 26,4 & 23,9 & 15,3 \\
\hline Rodrigo Andrade & Controle & 10 & $-0,4$ & 25 & 25,5 & 47 & 27,8 & 19,2 & 13,1 \\
\hline Rodrigo Bueno & Controle & 5,6 & 1,5 & 26,2 & 24,7 & 51,3 & 26,6 & 27,2 & 11,5 \\
\hline Rog,rio G, Vilela & Controle & 6,4 & 1,7 & 24,6 & 22,8 & 54,3 & 28,2 & 27,8 & 15,7 \\
\hline Rosemeire Simonet & Controle & 9,5 & 1 & 26,9 & 25,9 & 52,2 & 22,5 & 28,6 & 10,3 \\
\hline Thays Damaceno & Controle & 5,6 & 4,7 & 30 & 25,3 & 55 & 26,2 & 18,6 & 11 \\
\hline Thais Freire & Controle & 5,2 & 6,3 & 27,3 & 21,1 & 50,5 & 24,3 & 22,3 & 15,8 \\
\hline Thelma C, Cozza & Controle & 4,9 & $-0,3$ & 25,3 & 25,7 & 51,3 & 26,4 & 27,2 & 8,5 \\
\hline
\end{tabular}




\begin{tabular}{|c|c|c|c|c|c|c|c|c|}
\hline Pacientes & Grupo & $\begin{array}{c}\text { Fhp- } \\
\text { ápice U6 f }\end{array}$ & $\begin{array}{c}\text { Ms-PP } \\
f\end{array}$ & $\begin{array}{c}\text { Mi- } \\
\text { GoMe f }\end{array}$ & II-GoMe f & $\begin{array}{c}\text { Nasolabial } \\
f\end{array}$ & Li-E f & Ls-E f \\
\hline Amanda M, Caredo & AEB conj & 21,7 & 20,3 & 24,2 & 33 & 112,8 & $-6,7$ & $-5,1$ \\
\hline Ana Cl udia Andre & AEB conj & 19,7 & 21,2 & 26 & 38,4 & 132,2 & $-2,6$ & -4 \\
\hline Ana Paula Rodrigh & AEB conj & 20,2 & 17,5 & 24,2 & 32 & 112,2 & 0,2 & $-0,4$ \\
\hline Andre Luis Gimene & AEB conj & 19,1 & 20,6 & 27,1 & 38,8 & 124,2 & 1,2 & $-3,2$ \\
\hline Carlos E, Cordeir & AEB conj & 26,4 & 22,5 & 28,5 & 40,8 & 123,6 & 3,9 & 1,5 \\
\hline Cristina Jer"nimo & AEB conj & 18,6 & 17,9 & 28,8 & 35,4 & 107,9 & 1,2 & $-0,7$ \\
\hline Daniel A, Calze & AEB conj & 19 & 20,5 & 24,5 & 36,5 & 108,4 & $-0,4$ & $-1,4$ \\
\hline Daniel A, Furlane & AEB conj & 22,1 & 21,4 & 26,8 & 39,7 & 129,8 & 3,6 & 3 \\
\hline Glaucia Rodrigher & AEB conj & 19,9 & 16,8 & 24 & 32,2 & 124,9 & $-2,5$ & $-3,2$ \\
\hline Gustavo F, Bizarr & AEB conj & 21,3 & 17,9 & 25,2 & 36,4 & 97,7 & $-0,6$ & $-1,3$ \\
\hline Israel L, Mufalo & AEB conj & 23,2 & 18,5 & 25,5 & 35,6 & 109,8 & $-0,9$ & $-1,6$ \\
\hline Jorge A, Bosolim & AEB conj & 21,8 & 19,6 & 26,1 & 34,2 & 110,7 & 0,2 & 0,6 \\
\hline Juliana B, de God & AEB conj & 19,5 & 19 & 23,7 & 37,8 & 109,3 & 4,3 & 1 \\
\hline Leandro Holgado & AEB conj & 21,3 & 22,3 & 28,5 & 40,5 & 137,3 & 3,6 & 3,1 \\
\hline Leandro R, Ferrar & AEB conj & 23,3 & 20,6 & 29,1 & 40,8 & 100,1 & 1,4 & 1,2 \\
\hline Murilo de O, Barr & AEB conj & 20,6 & 19,5 & 26,5 & 36,3 & 115,8 & 0 & $-2,4$ \\
\hline Nat lia & AEB conj & 19,5 & 19 & 25,3 & 33,6 & 136,9 & $-1,9$ & $-3,1$ \\
\hline Paula Bush & AEB conj & 18,8 & 19,2 & 26,8 & 39,9 & 110,6 & $-0,2$ & -1 \\
\hline Paula R, Secco & AEB conj & 18,8 & 17,9 & 25,5 & 37,7 & 127,3 & 2,1 & $-0,6$ \\
\hline Paulo de Tarso & AEB conj & 25,9 & 26,3 & 35,1 & 47,5 & 124,6 & 6,8 & 4 \\
\hline Priscila & AEB conj & 26,9 & 20,7 & 27,9 & 36,1 & 97,4 & 0,3 & $-0,7$ \\
\hline Rodrigo Magri & AEB conj & 24,2 & 20,9 & 25,7 & 37,3 & 121,2 & $-2,4$ & $-2,2$ \\
\hline Talita C, Bamichi & AEB conj & 21,4 & 18,2 & 25,4 & 33,6 & 117,5 & -4 & $-3,3$ \\
\hline Thiago Concer & AEB conj & 25,9 & 24,6 & 30,6 & 42,4 & 120,1 & 1,4 & $-0,5$ \\
\hline Vera L£cia Santan & AEB conj & 19,1 & 18 & 28,3 & 37,4 & 122,4 & 0,1 & $-1,3$ \\
\hline Ang,lica G, Ribei & AEB IHG & 23,6 & 21,5 & 27,9 & 40,2 & 100,3 & $-0,9$ & $-2,6$ \\
\hline Atila Mariano & AEB IHG & 24,2 & 24,1 & 27,7 & 44,1 & 112,8 & 1,8 & $-2,2$ \\
\hline Bianca Silva & AEB IHG & 28,4 & 22,1 & 33,3 & 46,4 & 94,3 & 5 & 3,7 \\
\hline Caio Garcia & AEB IHG & 26,1 & 19,2 & 25 & 37,6 & 111 & 1,6 & $-1,1$ \\
\hline Carlos Carnevale & AEB IHG & 18,2 & 22,2 & 29 & 42,1 & 118,4 & 1,1 & $-1,3$ \\
\hline David Silva & AEB IHG & 22,2 & 19,8 & 26,6 & 39,3 & 105,4 & 1,5 & 0,4 \\
\hline D,bora Silva & AEB IHG & 20,4 & 18,1 & 28 & 40 & 122,6 & 2,4 & 4,4 \\
\hline Elizabeth Silva & AEB IHG & 20,9 & 21,4 & 29,2 & 41,6 & 107,3 & 0 & $-3,3$ \\
\hline Fernanda Santos & AEB IHG & 24,1 & 19,3 & 29,1 & 39,7 & 96,2 & 2,4 & $-0,1$ \\
\hline Fernando Leandro & AEB IHG & 24 & 21,5 & 32,5 & 47,1 & 95,4 & 3,3 & $-0,4$ \\
\hline Flavia Menes & AEB IHG & 20,2 & 19,4 & 26,7 & 38,6 & 125,1 & 0 & $-3,6$ \\
\hline Graziela Munhoz & AEB IHG & 18,1 & 18,7 & 23,1 & 35,7 & 118,6 & 2,9 & 1,1 \\
\hline Jonatas Cossonich & AEB IHG & 21,8 & 19,1 & 27,8 & 38,5 & 105,7 & 6,6 & 2,1 \\
\hline Jorge J£nior & AEB IHG & 23,7 & 24,1 & 30,4 & 45,4 & 103 & 2,8 & $-0,8$ \\
\hline Jowatas Cossonich & AEB IHG & 19,9 & 19,9 & 28,2 & 39 & 88,2 & 6,3 & 0,8 \\
\hline Lais Y, Zuciari & AEB IHG & 19,9 & 20,2 & 27,6 & 38,9 & 102,3 & 1,5 & $-1,8$ \\
\hline Leonardo Nogueira & AEB IHG & 21,4 & 21,8 & 25,2 & 37,1 & 115 & 1,8 & 0,9 \\
\hline Marco Garcia & AEB IHG & 24,6 & 23,6 & 31,7 & 44,8 & 105,4 & 3,9 & $-1,1$ \\
\hline Murilo Silva & AEB IHG & 24,3 & 20,7 & 26,8 & 38,6 & 110,5 & 2,3 & 0,3 \\
\hline Nayla Melhem & AEB IHG & 24,7 & 20 & 28,9 & 40,7 & 110,2 & 1,2 & 1,6 \\
\hline Patricia Pereira & AEB IHG & 18,3 & 18,9 & 28,4 & 38,5 & 103 & $-0,5$ & $-2,5$ \\
\hline Paula Soares & AEB IHG & 16,1 & 18 & 30,9 & 41,8 & 111,9 & 3,9 & $-0,3$ \\
\hline Samuel Goncalves & AEB IHG & 18,6 & 21,5 & 26,4 & 37,6 & 115,9 & 1,1 & $-1,1$ \\
\hline Thalita Ferreira & AEB IHG & 22,2 & 19,2 & 26,9 & 40 & 114 & 0,4 & $-1,5$ \\
\hline Willian G, M,Lope & AEB IHG & 23,4 & 19,9 & 28,6 & 39,4 & 105,2 & 1,9 & 0,4 \\
\hline
\end{tabular}


Apêndice 163

\begin{tabular}{|c|c|c|c|c|c|c|c|c|}
\hline Pacientes & Grupo & $\begin{array}{c}\text { Fhp- } \\
\text { ápice U6 } \\
f\end{array}$ & Ms-PP f & $\begin{array}{c}\text { Mi- } \\
\text { GoMe f }\end{array}$ & $\underset{f}{\mathrm{II}-\mathrm{GoMe}}$ & $\begin{array}{c}\text { Nasolabial } \\
f\end{array}$ & Li-E f & LS-E f \\
\hline Alexandre G, Mend & Controle & 26,7 & 21,3 & 28 & 44,1 & 107,7 & $-3,7$ & $-3,7$ \\
\hline Carla F, Z, Soare & Controle & 26,6 & 18,6 & 30,3 & 37,5 & 128 & 1,2 & 0,4 \\
\hline Denis C, Fileti & Controle & 27,7 & 19,5 & 26,9 & 40,2 & 111,1 & 2,8 & $-1,2$ \\
\hline Diego B, Vides & Controle & 30,4 & 23,4 & 28 & 38,3 & 117,2 & $-2,3$ & $-2,4$ \\
\hline Fabiana Buzalaf & Controle & 21,2 & 18,8 & 25,2 & 35 & 125,2 & 1,1 & $-2,8$ \\
\hline Flaviana Andrade & Controle & 26,5 & 21,1 & 27,4 & 41,1 & 124,3 & 4,4 & 2,8 \\
\hline Giedre R, Ponce & Controle & 25,6 & 19,1 & 25 & 32,9 & 117,4 & $-4,2$ & $-3,8$ \\
\hline Jaime $\mathrm{C}, \mathrm{M}, \mathrm{J} £$ nio & Controle & 24,5 & 20,2 & 25,9 & 37,4 & 120,5 & $-1,4$ & $-2,2$ \\
\hline Jos, A, de A,Card & Controle & 24,5 & 20,6 & 28,3 & 38,7 & 117,7 & $-2,3$ & $-3,3$ \\
\hline Lucas de $R, P$, Co & Controle & 25 & 21,4 & 22,4 & 34,9 & 116,8 & 0,6 & 0,9 \\
\hline Marcelo Ticianeli & Controle & 26,9 & 21,5 & 30,8 & 41,6 & 121,8 & 2,7 & 0,7 \\
\hline Mirela Guareschi & Controle & 22 & 22 & 28,3 & 38,6 & 130,5 & 2,8 & $-1,8$ \\
\hline Nat lia B, Fonsat & Controle & 29 & 18,6 & 28 & 35,3 & 112,1 & 1,6 & 0,8 \\
\hline Nat lia R, Tonett & Controle & 26,7 & 24,4 & 28,5 & 39,1 & 111,7 & -1 & $-0,8$ \\
\hline Osvaldo Cruz & Controle & 15,1 & 18,6 & 27,3 & 37,5 & 127,2 & $-5,9$ & $-1,4$ \\
\hline Patricia B, Medin & Controle & 27,4 & 20,8 & 27,3 & 38,3 & 130 & $-1,9$ & $-4,4$ \\
\hline Plinio B Jr & Controle & 26,3 & 18,6 & 28,5 & 38,2 & 125,1 & $-1,9$ & $-3,3$ \\
\hline Rafael G, Sanches & Controle & 26,5 & 21 & 28,4 & 38,6 & 95,1 & $-3,6$ & $-3,2$ \\
\hline Rodrigo Andrade & Controle & 23,2 & 18,2 & 29 & 38,4 & 118,6 & 1,6 & 1,9 \\
\hline Rodrigo Bueno & Controle & 22,3 & 19,5 & 26,4 & 36,5 & 113,6 & $-1,6$ & $-2,9$ \\
\hline Rog,rio G, Vilela & Controle & 27,3 & 21,9 & 29,9 & 40,2 & 145,2 & $-1,4$ & $-1,1$ \\
\hline Rosemeire Simonet & Controle & 22,6 & 15,9 & 23,9 & 33,7 & 126,1 & $-2,2$ & $-1,4$ \\
\hline Thays Damaceno & Controle & 23,1 & 19,6 & 24,9 & 37 & 117,9 & $-3,3$ & $-4,2$ \\
\hline Thais Freire & Controle & 26,5 & 17 & 24,9 & 33,2 & 115 & $-3,1$ & $-2,3$ \\
\hline Thelma C, Cozza & Controle & 21,2 & 19,4 & 28,4 & 39,1 & 109,1 & 0,3 & $-1,8$ \\
\hline
\end{tabular}


APÊNDICE 3 - Diferença dos valores finais e iniciais para todas as variáveis para os três grupos.

\begin{tabular}{|c|c|c|c|c|c|c|c|c|c|}
\hline Pacientes & Grupo & SNA f-i & fhp-A f-i & CoA f-i & SNB f-i & CoGn f-i & ANB f-i & AFAI f-i & SN,GoMe f-i \\
\hline Amanda M, Caredo & AEB conj & -3 & 0,7 & 0,2 & $-0,8$ & 1,2 & -2 & $-4,6$ & $-2,3$ \\
\hline Ana Cl udia Andre & AEB conj & 1,1 & $-0,7$ & -1 & 2,1 & $-1,3$ & -1 & $-3,1$ & $-1,5$ \\
\hline Ana Paula Rodrigh & AEB conj & -3 & $-4,5$ & $-1,7$ & $-0,2$ & 0,1 & -3 & $-0,6$ & $-3,3$ \\
\hline Andre Luis Gimene & AEB conj & 1,5 & 1 & 1,6 & 1,4 & 3,9 & 0,1 & 3,2 & $-3,8$ \\
\hline Carlos E, Cordeir & AEB conj & $-3,3$ & $-1,2$ & 0,3 & 0,3 & 3 & $-3,5$ & 2,9 & $-4,8$ \\
\hline Cristina Jer"nimo & AEB conj & 1,9 & 2,6 & 2,2 & 2,8 & 3 & $-0,9$ & 0,7 & $-3,6$ \\
\hline Daniel A, Calze & AEB conj & $-3,2$ & $-1,3$ & $-2,6$ & $-1,1$ & $-1,5$ & $-2,2$ & $-0,1$ & 1,4 \\
\hline Daniel A, Furlane & AEB conj & $-3,9$ & 1,2 & 2,3 & $-3,4$ & 1,2 & $-0,5$ & $-1,3$ & 3,7 \\
\hline Glaucia Rodrigher & AEB conj & $-5,3$ & $-0,8$ & $-1,7$ & $-8,5$ & 0,4 & 3,2 & 1,7 & 3,6 \\
\hline Gustavo F, Bizarr & AEB conj & 0,4 & 0,6 & 1,9 & 1,4 & 0,3 & -1 & 2,1 & $-4,3$ \\
\hline Israel L, Mufalo & AEB conj & 0,1 & $-0,2$ & $-1,6$ & 0,9 & 0,3 & $-0,8$ & -1 & $-2,5$ \\
\hline Jorge A, Bosolim & AEB conj & 1,4 & 0,7 & $-0,3$ & 2,7 & 1,1 & $-1,2$ & $-3,1$ & $-5,2$ \\
\hline Juliana B, de God & AEB conj & $-0,2$ & 0,5 & 0,3 & 0,2 & $-0,1$ & $-0,3$ & $-1,1$ & 0,1 \\
\hline Leandro Holgado & AEB conj & $-0,3$ & 0,1 & 1,2 & 0,8 & 6,1 & $-1,1$ & 4,4 & 3,1 \\
\hline Leandro R, Ferrar & AEB conj & 0,6 & 2,5 & 5,3 & 2,8 & 8,6 & $-2,2$ & 4,2 & $-2,6$ \\
\hline Murilo de O, Barr & AEB conj & 1,9 & 2,1 & $-1,1$ & 2,6 & 3,6 & $-0,8$ & 3 & $-1,9$ \\
\hline Nat lia & AEB conj & $-1,6$ & $-0,2$ & 1,4 & $-1,6$ & 2,5 & $-0,2$ & 0,7 & 0,9 \\
\hline Paula Bush & AEB conj & $-2,5$ & $-0,9$ & $-1,8$ & $-0,9$ & $-0,7$ & $-1,5$ & 1,5 & $-1,8$ \\
\hline Paula R, Secco & AEB conj & 0,2 & -1 & $-0,6$ & 2,5 & 2,6 & $-2,3$ & 0,3 & $-4,5$ \\
\hline Paulo de Tarso & AEB conj & 0,1 & 1,5 & 1,8 & 0,8 & 5 & $-0,7$ & 3,9 & $-2,4$ \\
\hline Priscila & AEB conj & $-0,5$ & 0,9 & 3 & 1,4 & 3,6 & -2 & 0,7 & $-2,4$ \\
\hline Rodrigo Magri & AEB conj & $-0,3$ & 0,6 & $-0,5$ & 1,3 & 2,4 & $-1,6$ & 3,6 & 0 \\
\hline Talita C, Bamichi & AEB conj & 4 & 2 & 1,8 & 4,5 & 2 & $-0,5$ & $-1,2$ & $-5,8$ \\
\hline Thiago Concer & AEB conj & 2,4 & 3,4 & -2 & 1,5 & $-1,3$ & 0,9 & 0,9 & 0,6 \\
\hline Vera L£cia Santan & AEB conj & $-0,2$ & $-0,9$ & 1,7 & 2 & 4,8 & $-2,2$ & 2,8 & $-2,8$ \\
\hline Ang,lica G, Ribei & AEB IHG & $-2,6$ & -2 & $-0,1$ & $-3,5$ & $-4,9$ & 0,9 & $-3,8$ & 1,5 \\
\hline Atila Mariano & AEB IHG & 2,2 & 0 & $-1,1$ & 3,1 & 2 & $-0,9$ & $-0,4$ & $-1,3$ \\
\hline Bianca Silva & AEB IHG & 0,3 & 3,2 & 0,8 & 2 & 4,7 & $-1,8$ & 1,8 & $-0,1$ \\
\hline Caio Garcia & AEB IHG & $-4,1$ & $-1,1$ & 0 & $\begin{array}{l}-0,3 \\
\end{array}$ & 2,2 & $-3,8$ & $-0,1$ & 3,1 \\
\hline Carlos Carnevale & AEB IHG & $-2,1$ & $-4,3$ & $-3,5$ & 3,3 & 0,7 & $-5,5$ & 1,2 & 0,9 \\
\hline David Silva & AEB IHG & $-3,3$ & $-2,3$ & $-1,1$ & $-0,1$ & 1 & $-3,2$ & 0,6 & 0,7 \\
\hline D,bora Silva & AEB IHG & $-1,6$ & $-1,9$ & 0,5 & $-1,4$ & $-1,5$ & $-0,3$ & 1,2 & 1,1 \\
\hline Elizabeth Silva & AEB IHG & $-1,3$ & $-0,3$ & $-0,8$ & 0,4 & 2,9 & $-1,6$ & 2,3 & 1,7 \\
\hline Fernanda Santos & AEB IHG & $-0,1$ & 0,8 & 3,4 & 0,3 & 2,7 & $-0,4$ & $-0,3$ & -1 \\
\hline Fernando Leandro & AEB IHG & 2,9 & 0,4 & 1,1 & 3,8 & 1,8 & $-0,9$ & 1,3 & $-4,5$ \\
\hline Flavia Menes & AEB IHG & $-3,6$ & $-1,3$ & 2 & $-2,5$ & 2,5 & -1 & 1,2 & 1 \\
\hline Graziela Munhoz & AEB IHG & $-4,8$ & $-0,4$ & 1 & $-2,6$ & 0,8 & $-2,3$ & $-1,4$ & $-2,9$ \\
\hline Jonatas Cossonich & AEB IHG & $-1,1$ & $-0,5$ & $-1,6$ & 2,2 & 3,5 & $-3,3$ & $-0,1$ & $-2,8$ \\
\hline Jorge J£nior & AEB IHG & 1,3 & 0,3 & 1 & 2,1 & 1,2 & $-0,8$ & $-0,7$ & $-2,6$ \\
\hline Jowatas Cossonich & AEB IHG & 1,1 & $-3,6$ & $-0,6$ & 3,4 & 4,5 & $-2,3$ & $-0,4$ & -6 \\
\hline Lais Y, Zuciari & AEB IHG & 1,2 & -2 & $-0,8$ & 3,3 & 5,2 & $-2,1$ & 2,6 & $-4,4$ \\
\hline Leonardo Nogueira & AEB IHG & $-3,9$ & $-0,7$ & 0,1 & $-5,6$ & 4,5 & 1,6 & 2,1 & 3,3 \\
\hline Marco Garcia & AEB IHG & 1,8 & 0,3 & $-0,2$ & 1,3 & 3,6 & 0,5 & 3,8 & $-0,8$ \\
\hline Murilo Silva & AEB IHG & 0,6 & $-2,1$ & 0,9 & 0,6 & 2 & $-0,1$ & $-0,2$ & 0,7 \\
\hline Nayla Melhem & AEB IHG & $-5,1$ & $-0,7$ & 0,2 & $-1,4$ & 4,6 & $-3,7$ & 4,9 & 4,5 \\
\hline Patricia Pereira & AEB IHG & -5 & 1,2 & 3,1 & -4 & 3,6 & -1 & 1,4 & 1,8 \\
\hline Paula Soares & AEB IHG & $-1,3$ & $-2,2$ & $-1,8$ & 2,5 & 2,1 & $-3,8$ & $-0,8$ & $-4,6$ \\
\hline Samuel Goncalves & AEB IHG & $-3,2$ & 0,6 & $-2,6$ & $-0,6$ & 2,2 & $-2,6$ & 2,8 & 2,1 \\
\hline Thalita Ferreira & AEB IHG & $-3,2$ & $-0,1$ & $-0,7$ & $-1,1$ & 2,1 & $-2,1$ & $-0,5$ & 0,5 \\
\hline Willian G, M,Lope & AEB IHG & 0 & $-0,1$ & 1,8 & 1,3 & 3,8 & $-1,3$ & 3,2 & -1 \\
\hline
\end{tabular}


Apêndice 165

\begin{tabular}{|c|c|c|c|c|c|c|c|c|c|}
\hline Pacientes & Grupo & SNA f-i & fhp-A f-i & CoA f-i & SNB f-i & CoGn f-i & ANB $f-i$ & AFAl f-i & $\begin{array}{c}\text { SN, GoMe } \\
f-i\end{array}$ \\
\hline Alexandre G, Mend & Controle & 0,5 & 51,6 & 3,8 & 0,4 & 4,8 & 0 & 1,1 & $-1,5$ \\
\hline Carla F, Z, Soare & Controle & 0,9 & 51 & 2 & 0,9 & 1 & 0 & $-1,1$ & $-2,6$ \\
\hline Denis C, Fileti & Controle & $-0,4$ & 49,9 & 0,7 & $-0,6$ & 0 & 0,2 & -1 & 0 \\
\hline Diego B, Vides & Controle & $-1,8$ & 54,3 & 2,6 & $-0,3$ & 4,7 & $-1,5$ & 0,2 & $-1,5$ \\
\hline Fabiana Buzalaf & Controle & $-2,7$ & 49,1 & 2,7 & $-0,6$ & 3 & $-2,2$ & -1 & $-0,1$ \\
\hline Flaviana Andrade & Controle & $-3,7$ & 52,5 & 5,5 & $-6,3$ & 0,9 & 2,5 & 0,8 & 4,3 \\
\hline Giedre R, Ponce & Controle & $-0,1$ & 48,8 & 0,5 & 0,6 & 2 & $-0,8$ & 2,2 & $-1,1$ \\
\hline Jaime C, M, J£nio & Controle & $-2,5$ & 50,5 & 5 & $-1,1$ & 4,5 & $-1,4$ & $-1,2$ & 0,1 \\
\hline Jos, A, de A,Card & Controle & 0,3 & 53,1 & 1,9 & 1,5 & 3,4 & $-1,2$ & 1,1 & -1 \\
\hline Lucas de R, P, Co & Controle & $-1,4$ & 46,7 & 0,6 & 0,5 & 3,6 & $-1,9$ & 0,4 & 1,1 \\
\hline Marcelo Ticianeli & Controle & 3,4 & 53,4 & 4,3 & $-0,6$ & 2,7 & 4 & 1,6 & 1,5 \\
\hline Mirela Guareschi & Controle & $-0,2$ & 45,5 & 2,1 & 0,6 & 4,4 & $-0,7$ & 1,8 & $-0,5$ \\
\hline Nat lia B, Fonsat & Controle & 2,9 & 48,4 & 1,4 & 2,4 & 4,2 & 0,5 & 1,3 & $-3,8$ \\
\hline Nat lia R, Tonett & Controle & 2,4 & 50,1 & 3,6 & 3,9 & 7,4 & $-1,5$ & 2,5 & $-2,6$ \\
\hline Osvaldo Cruz & Controle & $-2,7$ & 44,8 & 1,1 & $-1,2$ & 5 & $-1,5$ & 1,3 & $-0,8$ \\
\hline Patricia B, Medin & Controle & $-2,7$ & 52,2 & $-0,5$ & $-0,8$ & 3,2 & $-1,8$ & 2,7 & 2,1 \\
\hline Plinio B Jr & Controle & 0,6 & 51,2 & 6,1 & 0,8 & 6,9 & $-0,1$ & 2,7 & $-3,4$ \\
\hline Rafael G, Sanches & Controle & $-0,9$ & 55,1 & 6,7 & $-1,5$ & 4,9 & 0,7 & 1,4 & $-0,1$ \\
\hline Rodrigo Andrade & Controle & 0 & 52,5 & $-1,2$ & 1 & 0,8 & $-1,1$ & 0,1 & $-0,2$ \\
\hline Rodrigo Bueno & Controle & 2,6 & 48,5 & 1,7 & 1,9 & $-0,4$ & 0,8 & 0 & $-1,9$ \\
\hline Rog,rio G, Vilela & Controle & 0,3 & 53,3 & 4,1 & 1,5 & 6,8 & $-1,2$ & 3 & $-1,9$ \\
\hline Rosemeire Simonet & Controle & $-1,5$ & 45,8 & 2 & $-1,6$ & 1,3 & 0,1 & $-2,8$ & $-1,6$ \\
\hline Thays C, Damaceno & Controle & 2,7 & 45,5 & 4,4 & 1,8 & 5,1 & 0,8 & 4,3 & 0,8 \\
\hline Thais Freire & Controle & 2,7 & 48,9 & 4,5 & 2,3 & 6,5 & 0,3 & 3 & $-3,6$ \\
\hline Thelma C, Cozza & Controle & $-1,6$ & 47,4 & 5,3 & $-0,5$ & 6,3 & $-1,1$ & 2,7 & $-2,2$ \\
\hline
\end{tabular}




\begin{tabular}{|c|c|c|c|c|c|c|c|c|c|}
\hline Pacientes & Grupo & $\begin{array}{c}\text { SNPP } \\
f-i\end{array}$ & $\begin{array}{l}\text { Frank- } \\
\text { Plo f-i }\end{array}$ & $\begin{array}{c}\text { PP- } \\
\text { GoMe f-i }\end{array}$ & $\underset{f-i}{\text { FrGoMe }}$ & $\begin{array}{c}\text { ArGo } \\
\text { GoMe f-i }\end{array}$ & 1,NA f-i & IS-PP f-i & $\begin{array}{c}\text { fhp- } \\
\text { distalU6 } \\
\mathrm{f}-\mathrm{i}\end{array}$ \\
\hline Amanda M, Caredo & AEB conj & 4,6 & $-4,2$ & -7 & $-2,9$ & 4,7 & $-15,1$ & $-1,3$ & 0,9 \\
\hline Ana $\mathrm{Cl}$ udia Andre & AEB conj & 1,8 & $-1,5$ & $-3,3$ & $-1,7$ & 1,5 & $-10,8$ & $-0,5$ & -1 \\
\hline Ana Paula Rodrigh & AEB conj & 1,4 & $-6,2$ & $-4,7$ & 1,5 & 2,7 & 11,4 & $-0,5$ & $-3,5$ \\
\hline Andre Luis Gimene & AEB conj & -1 & $-2,6$ & $-2,9$ & $-0,3$ & 0,6 & $-6,5$ & 1,3 & -1 \\
\hline Carlos E, Cordeir & AEB conj & -3 & 1,4 & $-1,8$ & $-3,2$ & 0,1 & 1,7 & 1,9 & $-3,8$ \\
\hline Cristina Jer"nimo & AEB conj & 1,3 & $-3,6$ & $-4,9$ & $-1,3$ & 6 & $-9,3$ & 0,4 & $-0,3$ \\
\hline Daniel A, Calze & AEB conj & 4,4 & $-5,3$ & $-3,1$ & 2,2 & $-3,3$ & $-13,6$ & 0,7 & $-5,6$ \\
\hline Daniel A, Furlane & AEB conj & 7 & $-2,6$ & $-3,2$ & $-0,6$ & 0 & $-12,6$ & -2 & $-3,7$ \\
\hline Glaucia Rodrigher & AEB conj & 1,3 & 4 & 2,3 & $-1,8$ & 0,3 & $-8,8$ & 3,2 & $-1,8$ \\
\hline Gustavo F, Bizarr & AEB conj & $-4,2$ & $-0,6$ & $-0,1$ & 0,5 & $-0,1$ & $-2,2$ & 0,5 & $-3,4$ \\
\hline Israel L, Mufalo & AEB conj & $-0,5$ & $-3,3$ & -2 & 1,4 & 0,5 & $-11,4$ & 1,6 & $-0,5$ \\
\hline Jorge A, Bosolim & AEB conj & 0,6 & $-6,1$ & $-5,7$ & 0,4 & 7,1 & 6,3 & $-2,8$ & 0,6 \\
\hline Juliana B, de God & AEB conj & 0,7 & $-0,3$ & $-0,6$ & $-0,3$ & -4 & 0,1 & $-1,9$ & $-0,6$ \\
\hline Leandro Holgado & AEB conj & 0,8 & 0,1 & 2,4 & 2,2 & -4 & $-5,3$ & 2 & $-0,2$ \\
\hline Leandro R, Ferrar & AEB conj & $-5,3$ & 2,2 & 2,7 & 0,4 & $-3,8$ & 1,9 & 3,2 & 1,9 \\
\hline Murilo de O, Barr & AEB conj & $-1,8$ & 0,5 & $-0,1$ & $-0,6$ & 2,2 & $-6,2$ & 1,1 & $-0,2$ \\
\hline Nat lia & AEB conj & 4,7 & $-5,3$ & $-3,8$ & 1,5 & $-1,1$ & $-11,5$ & 0,8 & $-3,2$ \\
\hline Paula Bush & AEB conj & -2 & $-0,4$ & 0,2 & 0,7 & 3,1 & $-8,8$ & 0,8 & $-5,2$ \\
\hline Paula R, Secco & AEB conj & $-3,2$ & 0,5 & $-1,3$ & $-1,8$ & 5,9 & -7 & 0 & $-2,4$ \\
\hline Paulo de Tarso & AEB conj & 1,3 & $-0,6$ & $-3,7$ & $-3,1$ & 3,5 & 1,7 & $-0,9$ & 1 \\
\hline Priscila & AEB conj & 1,2 & $-3,5$ & $-3,6$ & 0 & 1,4 & $-12,3$ & 2,3 & $-1,3$ \\
\hline Rodrigo Magri & AEB conj & $-3,2$ & 2,2 & 3,2 & 1 & 1,2 & $-7,6$ & 2,3 & $-0,4$ \\
\hline Talita C, Bamichi & AEB conj & $-3,3$ & 0,3 & $-2,5$ & $-2,8$ & 0,9 & $-4,9$ & $-0,8$ & 2,3 \\
\hline Thiago Concer & AEB conj & $-2,2$ & 2,6 & 2,9 & 0,3 & $-4,5$ & $-4,3$ & 0,9 & 2,7 \\
\hline Vera L£cia Santan & AEB conj & 1,1 & $-4,6$ & $-3,9$ & 0,7 & 10 & 5,1 & 3 & $-2,8$ \\
\hline Ang,lica G, Ribei & AEB IHG & 2,4 & $-0,5$ & -1 & $-0,4$ & 0,6 & 2 & $-0,7$ & -4 \\
\hline Atila Mariano & AEB IHG & $-3,1$ & $-2,9$ & 1,8 & 4,7 & $-0,6$ & $-6,1$ & $-1,3$ & $-2,7$ \\
\hline Bianca Silva & AEB IHG & 0,3 & $-2,7$ & $-0,4$ & 2,3 & 6,9 & $-1,7$ & 0,8 & $-1,3$ \\
\hline Caio Garcia & AEB IHG & 0,3 & $-0,1$ & 2,8 & 2,9 & $-0,6$ & 11,5 & $-0,1$ & $-3,9$ \\
\hline Carlos Carnevale & AEB IHG & 0,2 & $-1,3$ & 0,8 & 2,1 & $-3,2$ & 2,4 & 0,6 & $-1,4$ \\
\hline David Silva & AEB IHG & 0,3 & $-2,1$ & 0,4 & 2,4 & $-0,9$ & $-3,2$ & 0,8 & -1 \\
\hline D,bora Silva & AEB IHG & 0,6 & $-2,7$ & 0,4 & 3,1 & $-0,3$ & 0,3 & 0,2 & -4 \\
\hline Elizabeth Silva & AEB IHG & 0,3 & -1 & 1,4 & 2,4 & 4,4 & $-0,1$ & $-0,2$ & $-1,4$ \\
\hline Fernanda Santos & AEB IHG & $-1,4$ & 1,7 & 0,4 & $-1,2$ & 1,4 & 1,7 & $-0,1$ & $-0,2$ \\
\hline Fernando Leandro & AEB IHG & $-5,5$ & $-0,7$ & 1 & 1,7 & 0,4 & 4,3 & $-0,8$ & $-4,7$ \\
\hline Flavia Menes & AEB IHG & 4,2 & $-4,5$ & $-3,2$ & 1,3 & 8,2 & $-2,1$ & 0,2 & $-7,9$ \\
\hline Graziela Munhoz & AEB IHG & 3,3 & $-3,2$ & $-6,3$ & $-3,1$ & 3,4 & 2,8 & $-0,5$ & $-1,4$ \\
\hline Jonatas Cossonich & AEB IHG & 2,7 & $-1,6$ & $-5,5$ & $-3,9$ & 0 & 2 & 0,6 & 0,9 \\
\hline Jorge J£nior & AEB IHG & 0,6 & $-1,1$ & $-3,2$ & $-2,2$ & $-0,4$ & 0,2 & 0,6 & $-0,3$ \\
\hline Jowatas Cossonich & AEB IHG & 0,2 & $-2,3$ & $-6,2$ & $-3,9$ & 4,7 & 2,9 & 0 & $-2,6$ \\
\hline Lais Y, Zuciari & AEB IHG & $-3,2$ & $-1,9$ & $-1,3$ & 0,6 & 5,2 & 1,6 & 0,8 & $-1,8$ \\
\hline Leonardo Nogueira & AEB IHG & 2,6 & $-0,8$ & 0,7 & 1,5 & 3,7 & 1,2 & 2,9 & 1,1 \\
\hline Marco Garcia & AEB IHG & $-3,5$ & $-0,6$ & 2,7 & 3,3 & -1 & 8,7 & 1,5 & 0,9 \\
\hline Murilo Silva & AEB IHG & $-2,2$ & 0,3 & 2,9 & 2,7 & $-0,5$ & 1 & 0,9 & $-3,1$ \\
\hline Nayla Melhem & AEB IHG & 1,5 & $-1,8$ & 3 & 4,7 & $-0,8$ & 2,4 & 2 & $-2,8$ \\
\hline Patricia Pereira & AEB IHG & 4,7 & 0,5 & $-2,9$ & $-3,4$ & 7 & 1,5 & 0 & $-0,7$ \\
\hline Paula Soares & AEB IHG & $-0,8$ & $-2,6$ & $-3,8$ & $-1,2$ & 1,2 & 0,5 & 0,8 & $-1,7$ \\
\hline Samuel Goncalves & AEB IHG & 0,6 & 4,9 & 1,5 & $-3,5$ & 1,3 & -2 & 2,6 & 1,2 \\
\hline Thalita Ferreira & AEB IHG & 1,8 & $-0,4$ & $-1,4$ & $-0,9$ & 0,2 & $-7,3$ & 1,1 & $-0,7$ \\
\hline Willian G, M,Lope & AEB IHG & 2,1 & $-4,4$ & $-3,1$ & 1,3 & $-1,6$ & $-0,8$ & 0,3 & $-3,8$ \\
\hline
\end{tabular}


Apêndice 167

\begin{tabular}{|c|c|c|c|c|c|c|c|c|c|}
\hline Pacientes & Grupo & SNPP f-i & $\begin{array}{l}\text { Frank- } \\
\text { Plo f-i }\end{array}$ & $\begin{array}{c}\text { PP- } \\
\text { GoMe f-i }\end{array}$ & $\begin{array}{l}\text { FrGoMe } \\
\mathrm{f}-\mathrm{i}\end{array}$ & $\begin{array}{c}\text { ArGo } \\
\text { GoMe f-i }\end{array}$ & $1, N A$ f-i & IS-PP f-i & $\begin{array}{c}\text { fhp- } \\
\text { distalU6 } \\
\mathrm{f}-\mathrm{i}\end{array}$ \\
\hline Alexandre G, Mend & Controle & 0,7 & 2 & $-2,2$ & $-4,1$ & 0,5 & 36,6 & 0,8 & 15,8 \\
\hline Carla F, Z, Soare & Controle & 1,8 & $-1,1$ & $-4,4$ & $-3,3$ & 2,6 & 19,7 & $-0,4$ & 14,6 \\
\hline Denis C, Fileti & Controle & $-0,7$ & 0,3 & 0,7 & 0,4 & $-1,2$ & 28,2 & $-0,6$ & 16,1 \\
\hline Diego B, Vides & Controle & 1,2 & $-0,4$ & $-2,8$ & $-2,4$ & 4,5 & 19 & $-0,2$ & 19,2 \\
\hline Fabiana Buzalaf & Controle & 3,1 & $-3,9$ & $-3,2$ & 0,6 & $-0,6$ & 22,3 & $-0,1$ & 12,7 \\
\hline Flaviana Andrade & Controle & 2,6 & 3,2 & 1,7 & $-1,5$ & 2,8 & 19 & 1,3 & 15,5 \\
\hline Giedre R, Ponce & Controle & $-1,1$ & $-2,9$ & 0 & 2,9 & $-0,2$ & 28,8 & 1,2 & 13,8 \\
\hline Jaime C, M, J£nio & Controle & 4,5 & $-3,6$ & $-4,4$ & $-0,8$ & $-4,2$ & 23 & 0,9 & 12,3 \\
\hline Jos, A, de A,Card & Controle & 0,7 & $-0,6$ & $-1,7$ & $-1,2$ & 1,5 & 9,9 & 0 & 12,9 \\
\hline Lucas de R, P, Co & Controle & 2,9 & $-3,4$ & $-1,8$ & 1,6 & 1,5 & 27 & 0,2 & 14,1 \\
\hline Marcelo Ticianeli & Controle & 2,7 & $-2,3$ & $-1,2$ & 1,2 & 2,4 & 20,1 & $-1,3$ & 15,7 \\
\hline Mirela Guareschi & Controle & 0,6 & $-0,7$ & -1 & $-0,3$ & 0,1 & 22,6 & 1,9 & 10,4 \\
\hline Nat lia B, Fonsat & Controle & $-1,8$ & 4,1 & $-1,9$ & $-6,1$ & 1,3 & 32,5 & 1,7 & 18 \\
\hline Nat lia R, Tonett & Controle & -3 & 2,7 & 0,4 & $-2,3$ & $-1,1$ & 23,1 & 0,8 & 16,1 \\
\hline Osvaldo Cruz & Controle & 2,7 & $-2,6$ & $-3,5$ & $-0,9$ & 0,6 & 25,7 & 0,8 & 3,5 \\
\hline Patricia B, Medin & Controle & 0 & 2,2 & 2,2 & 0,1 & 0 & 22,7 & $-0,2$ & 15,7 \\
\hline Plinio B Jr & Controle & -1 & $-0,7$ & $-2,4$ & $-1,7$ & 1 & 19,5 & 1,6 & 18,1 \\
\hline Rafael G, Sanches & Controle & 3,6 & $-1,8$ & $-3,7$ & $-1,9$ & 2,4 & 23,9 & 0,9 & 15,3 \\
\hline Rodrigo Andrade & Controle & 0,6 & $-2,8$ & $-0,8$ & 2 & 2,8 & 19,2 & -1 & 13,1 \\
\hline Rodrigo Bueno & Controle & $-2,7$ & 0,8 & 0,8 & 0 & $-2,2$ & 27,2 & 0,9 & 11,5 \\
\hline Rog,rio G, Vilela & Controle & 0,3 & $-1,5$ & $-2,2$ & $-0,7$ & 2 & 27,8 & 1 & 15,7 \\
\hline Rosemeire Simonet & Controle & 0,8 & $-0,2$ & $-2,4$ & $-2,2$ & 2,4 & 28,6 & 1 & 10,3 \\
\hline Thays C, Damaceno & Controle & $-0,6$ & $-0,6$ & 1,4 & 2 & 3,3 & 18,6 & 1,6 & 11 \\
\hline Thais Freire & Controle & -3 & 1,2 & $-0,6$ & $-1,7$ & 3,3 & 22,3 & 2,4 & 15,8 \\
\hline Thelma C, Cozza & Controle & 2,7 & $-3,3$ & -5 & $-1,6$ & 4,4 & 27,2 & 1,4 & 8,5 \\
\hline
\end{tabular}




\begin{tabular}{|c|c|c|c|c|c|c|c|c|}
\hline Pacientes & Grupo & $\begin{array}{c}\text { Fhp- ápice } \\
\text { U6 f-i }\end{array}$ & $\begin{array}{c}\text { Ms-PP } \\
f-i\end{array}$ & $\begin{array}{c}\text { Mi- } \\
\text { GoMef- i }\end{array}$ & $\begin{array}{c}\text { II-GoMe } \\
f-i\end{array}$ & $\begin{array}{c}\text { Nasolabi } \\
\text { al } f-i\end{array}$ & Li-E f-i & Ls-E f-i \\
\hline Amanda M, Caredo & AEB conj & 1,3 & 1,3 & $-1,8$ & $-0,1$ & $-6,8$ & $-3,6$ & $-3,9$ \\
\hline Ana $\mathrm{Cl}$ udia Andre & AEB conj & -2 & 0,3 & $-0,6$ & $-2,7$ & 16,1 & $-1,2$ & $-3,1$ \\
\hline Ana Paula Rodrigh & AEB conj & $-3,5$ & 1,1 & $-0,1$ & $-1,3$ & $-1,3$ & 0,6 & $-0,9$ \\
\hline Andre Luis Gimene & AEB conj & $-2,4$ & 2,6 & 2,6 & 1,3 & 19,2 & 1,1 & -3 \\
\hline Carlos E, Cordeir & AEB conj & $-2,3$ & 2 & $-0,4$ & $-0,5$ & 15,6 & $-1,4$ & $-1,9$ \\
\hline Cristina Jer"nimo & AEB conj & $-1,8$ & 1,2 & 1,9 & 0,1 & 5,9 & $-3,4$ & $-3,4$ \\
\hline Daniel A, Calze & AEB conj & $-4,5$ & 0,1 & 0,5 & 0,9 & 8,4 & $-0,9$ & $-2,8$ \\
\hline Daniel A, Furlane & AEB conj & $-2,2$ & $-0,2$ & $-1,4$ & 1,1 & 26,7 & 1,4 & 2,1 \\
\hline Glaucia Rodrigher & AEB conj & $-4,6$ & 0,3 & 0,4 & 3 & 11,3 & $-3,2$ & $-3,2$ \\
\hline Gustavo F, Bizarr & AEB conj & -3 & 0,4 & 0,2 & $-0,9$ & $-25,9$ & $-2,7$ & 0,6 \\
\hline Israel L, Mufalo & AEB conj & $-0,7$ & 0,9 & 0,3 & 0,2 & $-15,5$ & $-3,7$ & $-2,4$ \\
\hline Jorge A, Bosolim & AEB conj & 0,9 & 1,1 & $-0,5$ & $-0,1$ & $-7,4$ & -1 & $-0,9$ \\
\hline Juliana B, de God & AEB conj & $-0,7$ & $-1,7$ & 2,2 & $-0,1$ & 7,2 & 0,5 & $-0,8$ \\
\hline Leandro Holgado & AEB conj & -1 & 2,4 & 1,8 & 3,2 & $-3,5$ & 0,4 & $-0,4$ \\
\hline Leandro R, Ferrar & AEB conj & 0,2 & 0,5 & 2,6 & 2,1 & 17,3 & $-0,3$ & $-2,5$ \\
\hline Murilo de O, Barr & AEB conj & $-0,2$ & $-0,6$ & 3,4 & 0,1 & 4,7 & 1,5 & $-2,5$ \\
\hline Nat lia & AEB conj & $-3,9$ & 1,2 & 1,9 & 1,1 & 10,5 & $-2,1$ & $-4,2$ \\
\hline Paula Bush & AEB conj & $-4,9$ & $-1,5$ & 1,6 & 0 & $-15,2$ & $-3,9$ & $-4,9$ \\
\hline Paula R, Secco & AEB conj & $-1,9$ & $-0,8$ & 1,2 & 1,2 & 9,7 & $-0,1$ & $-3,3$ \\
\hline Paulo de Tarso & AEB conj & 0,3 & 2,4 & 3 & 0,5 & 17,8 & 0,6 & 0,7 \\
\hline Priscila & AEB conj & $-2,1$ & 0,5 & 1,6 & 0 & -13 & $-1,1$ & $-2,8$ \\
\hline Rodrigo Magri & AEB conj & $-0,6$ & 0,4 & 1,7 & 0,4 & 11,1 & $-0,6$ & $-2,9$ \\
\hline Talita C, Bamichi & AEB conj & 1 & $-0,5$ & 1,5 & 0,5 & $-8,7$ & $-1,4$ & $-0,7$ \\
\hline Thiago Concer & AEB conj & 0,6 & 0,1 & $-0,6$ & $-0,3$ & $-11,4$ & 1,8 & 1 \\
\hline Vera L£cia Santan & AEB conj & $-2,9$ & 2,3 & 2,7 & 3,6 & $-10,2$ & 2 & $-0,6$ \\
\hline Ang,lica G, Ribei & AEB IHG & $-3,7$ & $-0,8$ & -2 & $-1,9$ & $-1,5$ & 0,1 & $-0,1$ \\
\hline Atila Mariano & AEB IHG & $-1,3$ & $-1,4$ & $-1,6$ & 0,2 & $-2,9$ & $-1,5$ & $-1,6$ \\
\hline Bianca Silva & AEB IHG & $-0,6$ & 0,6 & 0,4 & 2,8 & 2,7 & 1 & $-1,5$ \\
\hline Caio Garcia & AEB IHG & $-1,7$ & $-1,1$ & $-0,7$ & 0,6 & 6,9 & $-0,5$ & $-1,8$ \\
\hline Carlos Carnevale & AEB IHG & $-2,4$ & 1,8 & 0,4 & 0,9 & 3,4 & $-1,3$ & $-0,2$ \\
\hline David Silva & AEB IHG & $-2,5$ & 0,1 & 0,8 & 0,2 & 2,3 & 0,2 & $-2,5$ \\
\hline D,bora Silva & AEB IHG & $-3,6$ & $-0,8$ & 0,8 & $-1,7$ & 2,7 & $-2,4$ & 0,7 \\
\hline Elizabeth Silva & AEB IHG & $-2,5$ & 0 & 1,9 & 3,6 & 2,5 & $-2,3$ & $-2,9$ \\
\hline Fernanda Santos & AEB IHG & $-0,6$ & $-0,8$ & 2 & 1 & $-3,8$ & $-0,3$ & $-1,4$ \\
\hline Fernando Leandro & AEB IHG & $-2,9$ & $-2,3$ & 0,8 & 1,3 & $-2,1$ & $-0,8$ & $-2,2$ \\
\hline Flavia Menes & AEB IHG & $-6,2$ & $-1,7$ & 2,2 & 1,7 & $-4,4$ & $-0,3$ & -1 \\
\hline Graziela Munhoz & AEB IHG & 0,2 & 1,2 & 1,2 & 1,2 & 6,7 & 2,4 & 0,6 \\
\hline Jonatas Cossonich & AEB IHG & 1,1 & 2,1 & 2,4 & 1 & 8,9 & 1,1 & $-2,2$ \\
\hline Jorge J£nior & AEB IHG & $-0,6$ & 1,3 & 0,9 & 0,4 & 6,6 & 0,2 & -3 \\
\hline Jowatas Cossonich & AEB IHG & $-4,3$ & 0,2 & 2,4 & 0,3 & $-5,2$ & 1,3 & $-2,6$ \\
\hline Lais Y, Zuciari & AEB IHG & -5 & $-1,5$ & 4 & 0,3 & -3 & $-2,2$ & $-3,3$ \\
\hline Leonardo Nogueira & AEB IHG & $-0,6$ & 3,5 & $-1,5$ & 0,9 & 1,1 & $-0,1$ & $-0,3$ \\
\hline Marco Garcia & AEB IHG & 0,9 & 2,2 & 1,5 & 2,6 & $-4,5$ & $-1,2$ & $-2,8$ \\
\hline Murilo Silva & AEB IHG & $-2,9$ & $-1,4$ & $-0,5$ & $-0,7$ & 1,2 & 1,5 & $-0,2$ \\
\hline Nayla Melhem & AEB IHG & $-0,1$ & 0,6 & 2,4 & 1,7 & 0,2 & -1 & 0,8 \\
\hline Patricia Pereira & AEB IHG & $-3,6$ & 1,3 & 2 & 0,8 & 3,4 & 0 & $-2,4$ \\
\hline Paula Soares & AEB IHG & $-5,5$ & $-1,1$ & 3,1 & 1,4 & 2,4 & $-2,5$ & $-4,4$ \\
\hline Samuel Goncalves & AEB IHG & $-1,3$ & $-0,2$ & 2,3 & 0,1 & 2,4 & -3 & $-2,5$ \\
\hline Thalita Ferreira & AEB IHG & 0 & $-0,9$ & $-0,1$ & 1 & $-7,5$ & $-1,2$ & $-1,5$ \\
\hline Willian G, M,Lope & AEB IHG & $-3,8$ & 1,7 & 1,9 & 1,3 & 5,2 & $-1,3$ & $-0,9$ \\
\hline
\end{tabular}


Apêndice 169

\begin{tabular}{|c|c|c|c|c|c|c|c|c|}
\hline Pacientes & Grupo & $\begin{array}{c}\text { Fhp- } \\
\text { ápice U6 } \\
\text { f-i }\end{array}$ & $\begin{array}{c}\text { Ms-PP f- } \\
\text { i }\end{array}$ & $\begin{array}{c}\text { Mi- } \\
\text { GoMef- i }\end{array}$ & $\begin{array}{c}\text { II-GoMe } \\
f-i\end{array}$ & $\begin{array}{c}\text { Nasolabial } \\
f-i\end{array}$ & Li-E f-i & Ls-E f-i \\
\hline Alexandre G, Mend & Controle & 3,1 & 2,5 & $-1,5$ & 1,3 & 107,7 & -1 & $-1,8$ \\
\hline Carla F, Z, Soare & Controle & 1,9 & 0,9 & 0,7 & 0 & 128 & $-0,3$ & $-1,4$ \\
\hline Denis C, Fileti & Controle & 3,5 & $-0,1$ & $-0,4$ & 0,9 & 111,1 & 0,1 & $-1,1$ \\
\hline Diego B, Vides & Controle & 0,7 & 0,9 & 1,1 & $-0,5$ & 117,2 & $-0,2$ & $-1,3$ \\
\hline Fabiana Buzalaf & Controle & $-4,3$ & 2,1 & $-1,7$ & 0,3 & 125,2 & 1,5 & $-1,6$ \\
\hline Flaviana Andrade & Controle & $-1,4$ & $-2,6$ & 1,1 & 4 & 124,3 & 0,7 & 1,9 \\
\hline Giedre R, Ponce & Controle & 1,3 & 2,5 & 0,2 & 1,6 & 117,4 & $-2,3$ & $-1,4$ \\
\hline Jaime C, M, J£nio & Controle & 4,8 & 2,2 & $-0,7$ & 1,9 & 120,5 & 1,1 & $-0,2$ \\
\hline Jos, A, de A,Card & Controle & 0 & 1,4 & 1,1 & 0,6 & 117,7 & $-1,4$ & $-0,5$ \\
\hline Lucas de R, P, Co & Controle & 1,2 & 2,4 & $-0,8$ & 2,2 & 116,8 & 0 & 0,6 \\
\hline Marcelo Ticianeli & Controle & $-2,8$ & $-1,7$ & 3,8 & 0,6 & 121,8 & 0,6 & $-0,6$ \\
\hline Mirela Guareschi & Controle & 2,7 & 2,2 & 0,9 & 0,4 & 130,5 & 0,9 & $-0,8$ \\
\hline Nat lia B, Fonsat & Controle & 3,5 & $-0,2$ & 2,4 & $-0,7$ & 112,1 & 0,6 & 1 \\
\hline Nat lia R, Tonett & Controle & 1 & 2,6 & $-0,1$ & 2,7 & 111,7 & $-1,2$ & $-0,9$ \\
\hline Osvaldo Cruz & Controle & $-4,4$ & 1,4 & 1,8 & 1,4 & 127,2 & 2,3 & $-0,9$ \\
\hline Patricia B, Medin & Controle & 3 & 1,2 & 0,1 & 1,4 & 130 & 2,1 & 0,3 \\
\hline Plinio B Jr & Controle & 1,4 & 0,7 & 3,7 & 0,8 & 125,1 & $-1,8$ & $-0,9$ \\
\hline Rafael G, Sanches & Controle & 1,7 & 1,4 & 0,5 & 1,8 & 95,1 & -1 & 0 \\
\hline Rodrigo Andrade & Controle & $-1,2$ & $-0,7$ & 0,8 & 0,8 & 118,6 & $-1,4$ & 0,3 \\
\hline Rodrigo Bueno & Controle & 2,2 & $-0,6$ & $-0,4$ & $-0,2$ & 113,6 & $-0,5$ & 0,9 \\
\hline Rog,rio G, Vilela & Controle & 0,6 & 2,1 & 1,7 & 2,1 & 145,2 & $-5,4$ & $-3,7$ \\
\hline Rosemeire Simonet & Controle & 2,6 & $-1,1$ & $-0,1$ & 0,1 & 126,1 & 1,2 & 0,3 \\
\hline Thays C, Damaceno & Controle & $-2,5$ & 0,4 & 0,5 & 3,6 & 117,9 & 0,7 & 0,8 \\
\hline Tha;s Freire & Controle & 2,5 & 1,3 & 2,1 & 1,1 & 115 & $-0,9$ & $-0,5$ \\
\hline Thelma C, Cozza & Controle & 1,5 & 2,2 & 2,1 & 0,7 & 109,1 & 1,4 & 1,9 \\
\hline
\end{tabular}




\begin{tabular}{|c|c|c|c|c|c|c|c|c|}
\hline Pacientes & Grupo & $\begin{array}{c}\text { IS-PP f- } \\
\text { i }\end{array}$ & $\begin{array}{c}\text { II-GoMe } \\
f-i\end{array}$ & CoA f-i & CoGn f-i & AFAI f-i & Li-E f-i & Ls-E f-i \\
\hline Amanda M, Caredo & AEB conj & $-1,3$ & $-0,1$ & 0,2 & 1,2 & $-4,6$ & $-3,6$ & $-3,9$ \\
\hline Ana $\mathrm{Cl}$ udia Andre & AEB conj & $-0,5$ & $-2,7$ & -1 & $-1,3$ & $-3,1$ & $-1,2$ & $-3,1$ \\
\hline Ana Paula Rodrigh & AEB conj & $-0,5$ & $-1,3$ & $-1,7$ & 0,1 & $-0,6$ & 0,6 & $-0,9$ \\
\hline Andre Luis Gimene & AEB conj & 1,3 & 1,3 & 1,6 & 3,9 & 3,2 & 1,1 & -3 \\
\hline Carlos E, Cordeir & AEB conj & 1,9 & $-0,5$ & 0,3 & 3 & 2,9 & $-1,4$ & $-1,9$ \\
\hline Cristina Jer"nimo & AEB conj & 0,4 & 0,1 & 2,2 & 3 & 0,7 & $-3,4$ & $-3,4$ \\
\hline Daniel A, Calze & AEB conj & 0,7 & 0,9 & $-2,6$ & $-1,5$ & $-0,1$ & $-0,9$ & $-2,8$ \\
\hline Daniel A, Furlane & AEB conj & -2 & 1,1 & 2,3 & 1,2 & $-1,3$ & 1,4 & 2,1 \\
\hline Glaucia Rodrigher & AEB conj & 3,2 & 3 & $-1,7$ & 0,4 & 1,7 & $-3,2$ & $-3,2$ \\
\hline Gustavo F, Bizarr & AEB conj & 0,5 & $-0,9$ & 1,9 & 0,3 & 2,1 & $-2,7$ & 0,6 \\
\hline Israel L, Mufalo & AEB conj & 1,6 & 0,2 & $-1,6$ & 0,3 & -1 & $-3,7$ & $-2,4$ \\
\hline Jorge A, Bosolim & AEB conj & $-2,8$ & $-0,1$ & $-0,3$ & 1,1 & $-3,1$ & -1 & $-0,9$ \\
\hline Juliana B, de God & AEB conj & $-1,9$ & $-0,1$ & 0,3 & $-0,1$ & $-1,1$ & 0,5 & $-0,8$ \\
\hline Leandro Holgado & AEB conj & 2 & 3,2 & 1,2 & 6,1 & 4,4 & 0,4 & $-0,4$ \\
\hline Leandro R, Ferrar & AEB conj & 3,2 & 2,1 & 5,3 & 8,6 & 4,2 & $-0,3$ & $-2,5$ \\
\hline Murilo de O, Barr & AEB conj & 1,1 & 0,1 & $-1,1$ & 3,6 & 3 & 1,5 & $-2,5$ \\
\hline Nat lia & AEB conj & 0,8 & 1,1 & 1,4 & 2,5 & 0,7 & $-2,1$ & $-4,2$ \\
\hline Paula Bush & AEB conj & 0,8 & 0 & $-1,8$ & $-0,7$ & 1,5 & $-3,9$ & $-4,9$ \\
\hline Paula R, Secco & AEB conj & 0 & 1,2 & $-0,6$ & 2,6 & 0,3 & $-0,1$ & $-3,3$ \\
\hline Paulo de Tarso & AEB conj & $-0,9$ & 0,5 & 1,8 & 5 & 3,9 & 0,6 & 0,7 \\
\hline Priscila & AEB conj & 2,3 & 0 & 3 & 3,6 & 0,7 & $-1,1$ & $-2,8$ \\
\hline Rodrigo Magri & AEB conj & 2,3 & 0,4 & $-0,5$ & 2,4 & 3,6 & $-0,6$ & $-2,9$ \\
\hline Talita C, Bamichi & AEB conj & $-0,8$ & 0,5 & 1,8 & 2 & $-1,2$ & $-1,4$ & $-0,7$ \\
\hline Thiago Concer & AEB conj & 0,9 & $-0,3$ & -2 & $-1,3$ & 0,9 & 1,8 & 1 \\
\hline Vera L£cia Santan & AEB conj & 3 & 3,6 & 1,7 & 4,8 & 2,8 & 2 & $-0,6$ \\
\hline Ang,lica G, Ribei & AEB IHG & $-0,7$ & $-1,9$ & $-0,1$ & $-4,9$ & $-3,8$ & 0,1 & $-0,1$ \\
\hline Atila Mariano & AEB IHG & $-1,3$ & 0,2 & $-1,1$ & 2 & $-0,4$ & $-1,5$ & $-1,6$ \\
\hline Bianca Silva & AEB IHG & 0,8 & 2,8 & 0,8 & 4,7 & 1,8 & 1 & $-1,5$ \\
\hline Caio Garcia & AEB IHG & $-0,1$ & 0,6 & 0 & 2,2 & $-0,1$ & $-0,5$ & $-1,8$ \\
\hline Carlos Carnevale & AEB IHG & 0,6 & 0,9 & $-3,5$ & 0,7 & 1,2 & $-1,3$ & $-0,2$ \\
\hline David Silva & AEB IHG & 0,8 & 0,2 & $-1,1$ & 1 & 0,6 & 0,2 & $-2,5$ \\
\hline D,bora Silva & AEB IHG & 0,2 & $-1,7$ & 0,5 & $-1,5$ & 1,2 & $-2,4$ & 0,7 \\
\hline Elizabeth Silva & AEB IHG & $-0,2$ & 3,6 & $-0,8$ & 2,9 & 2,3 & $-2,3$ & $-2,9$ \\
\hline Fernanda Santos & AEB IHG & $-0,1$ & 1 & 3,4 & 2,7 & $-0,3$ & $-0,3$ & $-1,4$ \\
\hline Fernando Leandro & AEB IHG & $-0,8$ & 1,3 & 1,1 & 1,8 & 1,3 & $-0,8$ & $-2,2$ \\
\hline Flavia Menes & AEB IHG & 0,2 & 1,7 & 2 & 2,5 & 1,2 & $-0,3$ & -1 \\
\hline Graziela Munhoz & AEB IHG & $-0,5$ & 1,2 & 1 & 0,8 & $-1,4$ & 2,4 & 0,6 \\
\hline Jonatas Cossonich & AEB IHG & 0,6 & 1 & $-1,6$ & 3,5 & $-0,1$ & 1,1 & $-2,2$ \\
\hline Jorge J£nior & AEB IHG & 0,6 & 0,4 & 1 & 1,2 & $-0,7$ & 0,2 & -3 \\
\hline Jowatas Cossonich & AEB IHG & 0 & 0,3 & $-0,6$ & 4,5 & $-0,4$ & 1,3 & $-2,6$ \\
\hline Lais Y, Zuciari & AEB IHG & 0,8 & 0,3 & $-0,8$ & 5,2 & 2,6 & $-2,2$ & $-3,3$ \\
\hline Leonardo Nogueira & AEB IHG & 2,9 & 0,9 & 0,1 & 4,5 & 2,1 & $-0,1$ & $-0,3$ \\
\hline Marco Garcia & AEB IHG & 1,5 & 2,6 & $-0,2$ & 3,6 & 3,8 & $-1,2$ & $-2,8$ \\
\hline Murilo Silva & AEB IHG & 0,9 & $-0,7$ & 0,9 & 2 & $-0,2$ & 1,5 & $-0,2$ \\
\hline Nayla Melhem & AEB IHG & 2 & 1,7 & 0,2 & 4,6 & 4,9 & -1 & 0,8 \\
\hline Patricia Pereira & AEB IHG & 0 & 0,8 & 3,1 & 3,6 & 1,4 & 0 & $-2,4$ \\
\hline Paula Soares & AEB IHG & 0,8 & 1,4 & $-1,8$ & 2,1 & $-0,8$ & $-2,5$ & $-4,4$ \\
\hline Samuel Goncalves & AEB IHG & 2,6 & 0,1 & $-2,6$ & 2,2 & 2,8 & -3 & $-2,5$ \\
\hline Thalita Ferreira & AEB IHG & 1,1 & 1 & $-0,7$ & 2,1 & $-0,5$ & $-1,2$ & $-1,5$ \\
\hline Willian G, M,Lope & AEB IHG & 0,3 & 1,3 & 1,8 & 3,8 & 3,2 & $-1,3$ & $-0,9$ \\
\hline
\end{tabular}


Apêndice 171

\begin{tabular}{|c|c|c|c|c|c|c|c|c|}
\hline Pacientes & Grupo & IS-PP f-i & $\begin{array}{c}\text { II-GoMe } \\
f-i\end{array}$ & CoA f-i & CoGn f-i & AFAl f-i & Li-E f-i & Ls-E f-i \\
\hline Alexandre G, Mend & Controle & 0,8 & 1,3 & 3,8 & 4,8 & 1,1 & -1 & $-1,8$ \\
\hline Carla F, Z, Soare & Controle & $-0,4$ & 0 & 2 & 1 & $-1,1$ & $-0,3$ & $-1,4$ \\
\hline Denis C, Fileti & Controle & $-0,6$ & 0,9 & 0,7 & 0 & -1 & 0,1 & $-1,1$ \\
\hline Diego B, Vides & Controle & $-0,2$ & $-0,5$ & 2,6 & 4,7 & 0,2 & $-0,2$ & $-1,3$ \\
\hline Fabiana Buzalaf & Controle & $-0,1$ & 0,3 & 2,7 & 3 & -1 & 1,5 & $-1,6$ \\
\hline Flaviana Andrade & Controle & 1,3 & 4 & 5,5 & 0,9 & 0,8 & 0,7 & 1,9 \\
\hline Giedre R, Ponce & Controle & 1,2 & 1,6 & 0,5 & 2 & 2,2 & $-2,3$ & $-1,4$ \\
\hline Jaime C, M, J£nio & Controle & 0,9 & 1,9 & 5 & 4,5 & $-1,2$ & 1,1 & $-0,2$ \\
\hline Jos, A, de A,Card & Controle & 0 & 0,6 & 1,9 & 3,4 & 1,1 & $-1,4$ & $-0,5$ \\
\hline Lucas de R, P, Co & Controle & 0,2 & 2,2 & 0,6 & 3,6 & 0,4 & 0 & 0,6 \\
\hline Marcelo Ticianeli & Controle & $-1,3$ & 0,6 & 4,3 & 2,7 & 1,6 & 0,6 & $-0,6$ \\
\hline Mirela Guareschi & Controle & 1,9 & 0,4 & 2,1 & 4,4 & 1,8 & 0,9 & $-0,8$ \\
\hline Nat lia B, Fonsat & Controle & 1,7 & $-0,7$ & 1,4 & 4,2 & 1,3 & 0,6 & 1 \\
\hline Nat lia R, Tonett & Controle & 0,8 & 2,7 & 3,6 & 7,4 & 2,5 & $-1,2$ & $-0,9$ \\
\hline Osvaldo Cruz & Controle & 0,8 & 1,4 & 1,1 & 5 & 1,3 & 2,3 & $-0,9$ \\
\hline Patricia B, Medin & Controle & $-0,2$ & 1,4 & $-0,5$ & 3,2 & 2,7 & 2,1 & 0,3 \\
\hline Plinio B Jr & Controle & 1,6 & 0,8 & 6,1 & 6,9 & 2,7 & $-1,8$ & $-0,9$ \\
\hline Rafael G, Sanches & Controle & 0,9 & 1,8 & 6,7 & 4,9 & 1,4 & -1 & 0 \\
\hline Rodrigo Andrade & Controle & -1 & 0,8 & $-1,2$ & 0,8 & 0,1 & $-1,4$ & 0,3 \\
\hline Rodrigo Bueno & Controle & 0,9 & $-0,2$ & 1,7 & $-0,4$ & 0 & $-0,5$ & 0,9 \\
\hline Rog,rio G, Vilela & Controle & 1 & 2,1 & 4,1 & 6,8 & 3 & $-5,4$ & $-3,7$ \\
\hline Rosemeire Simonet & Controle & 1 & 0,1 & 2 & 1,3 & $-2,8$ & 1,2 & 0,3 \\
\hline Thays C, Damaceno & Controle & 1,6 & 3,6 & 4,4 & 5,1 & 4,3 & 0,7 & 0,8 \\
\hline Thais Freire & Controle & 2,4 & 1,1 & 4,5 & 6,5 & 3 & $-0,9$ & $-0,5$ \\
\hline Thelma C, Cozza & Controle & 1,4 & 0,7 & 5,3 & 6,3 & 2,7 & 1,4 & 1,9 \\
\hline
\end{tabular}


APÊNDICE 4 - Análise de variância (ANOVA) para os três grupos das variáveis finais, e teste de Tukey.

\begin{tabular}{|c|c|c|c|c|c|}
\hline \multirow{2}{*}{$\begin{array}{c}\text { Grandezas } \\
\text { Cefalométricas }\end{array}$} & \multicolumn{3}{|c|}{$\begin{array}{l}\text { Médias das medidas } \\
\text { finais }\end{array}$} & \multirow{2}{*}{$\begin{array}{l}\text { Análise de } \\
\text { Variância } \\
\text { P }\end{array}$} & \multirow[t]{2}{*}{ Significância } \\
\hline & $\begin{array}{c}\text { Grupo } \\
1\end{array}$ & $\begin{array}{c}\text { Grupo } \\
2\end{array}$ & $\begin{array}{c}\text { Grupo } \\
3\end{array}$ & & \\
\hline \multicolumn{6}{|c|}{ Componentes maxilares } \\
\hline SNA & 85,06 & 81,68 & 82,15 & 0,002 & SIG** \\
\hline FHP-A & 48,46 & 48,01 & 50,00 & 0,058 & N/SIG \\
\hline Co-A & 80,93 & 81,60 & 83,87 & 0,050 & N/SIG \\
\hline \multicolumn{6}{|c|}{ Componentes mandibulares } \\
\hline SNB & 78,79 & 75,59 & 77,20 & 0,003 & SIG** \\
\hline Co-Gn & 101,54 & 103,52 & 103,72 & 0,348 & N/SIG \\
\hline \multicolumn{6}{|c|}{ Relação maxilomandibulares } \\
\hline ANB & 6,26 & 6,08 & 4,93 & 0,052 & N/SIG \\
\hline \multicolumn{6}{|c|}{ Componentes verticais } \\
\hline AFAl & 60,45 & 65,56 & 59,74 & 0,000 & SIG** \\
\hline SN.GoMe & 34,43 & 40,77 & 33,16 & 0,000 & SIG** \\
\hline SN.PP & 6,31 & 7,01 & 7,25 & 0,576 & N/SIG \\
\hline FRANK.Plo & 0,84 & 1,96 & 1,64 & 0,444 & N/SIG \\
\hline PP.GoMe & 28,13 & 33,75 & 25,90 & 0,000 & SIG** \\
\hline FRANK.GoMe & 27,28 & 31,78 & 24,28 & 0,000 & SIG** \\
\hline ArGo.GoMe & 49,63 & 46,44 & 51,08 & 0,004 & SIG** \\
\hline \multicolumn{6}{|c|}{ Componentes dentoalveolares superiores } \\
\hline 1.NA & 20,06 & 22,44 & 23,77 & 0,083 & N/SIG \\
\hline 1-PP & 25,44 & 28,76 & 26,42 & 0,000 & SIG** \\
\hline FHP-DISTAL $\underline{6}$ & 10,08 & 10,67 & 13,82 & 0,000 & SIG** \\
\hline FHP-ÁPICE 6 & 21,52 & 21,97 & 24,99 & 0,000 & $\mathrm{SIG}^{\star \star}$ \\
\hline 6-PP & 20,04 & 20,57 & 20,40 & 0,553 & N/SIG \\
\hline \multicolumn{6}{|c|}{ Componentes dentoalveolares inferiores } \\
\hline$\overline{6}$-GoMe & 26,77 & 28,24 & 27,28 & 0,080 & N/SIG \\
\hline$\overline{1}$-GoMe & 37,35 & 40,50 & 37,81 & 0,001 & SIG** \\
\hline \multicolumn{6}{|c|}{ Componentes tegumentares } \\
\hline ANL & 117,38 & 107,90 & 119,39 & 0,000 & SIG** \\
\hline Li-E & 0,32 & 2,17 & $-0,82$ & 0,000 & SIG** \\
\hline LS-E & $-0,86$ & $-0,32$ & $-1,62$ & 0,091 & N/SIG \\
\hline
\end{tabular}

N/SIG: não significante

SIG*: significante $(p<0,05)$

SIG**: significante $(p<0,01)$ 


\begin{tabular}{|c|c|c|c|c|}
\hline \multirow{2}{*}{$\begin{array}{c}\text { Grandezas } \\
\text { Cefalométricas }\end{array}$} & \multicolumn{2}{|c|}{$\begin{array}{c}\text { Médias das } \\
\text { medidas finais }\end{array}$} & \multirow{2}{*}{$\begin{array}{c}\text { Tuckey } \\
\text { P }\end{array}$} & \multirow[t]{2}{*}{ Significância } \\
\hline & $\begin{array}{c}\text { Grupo } \\
1\end{array}$ & $\begin{array}{c}\text { Grupo } \\
2\end{array}$ & & \\
\hline \multicolumn{5}{|c|}{ Componentes maxilares } \\
\hline SNA & 85,06 & 81,68 & 0,003 & SIG** \\
\hline \multicolumn{5}{|c|}{ Componentes mandibulares } \\
\hline SNB & 78,79 & 75,59 & 0,002 & SIG** \\
\hline \multicolumn{5}{|c|}{ Componentes verticais } \\
\hline AFAl & 60,45 & 65,56 & 0,002 & SIG** \\
\hline SN.GoMe & 34,43 & 40,77 & 0,000 & SIG** \\
\hline PP.GoMe & 28,13 & 33,75 & 0,000 & SIG** \\
\hline FRANK.GoMe & 27,28 & 31,78 & 0,000 & SIG** \\
\hline ArGo.GoMe & 49,63 & 46,44 & 0,058 & N/SIG \\
\hline \multicolumn{5}{|c|}{ Componentes dentoalveolares superiores } \\
\hline FHP-DISTAL 6 & 10,08 & 10,67 & 0,768 & N/SIG \\
\hline FHP-ÁPICE 6 & 21,52 & 21,97 & 0,852 & N/SIG \\
\hline 1-PP & 25,44 & 28,76 & 0,000 & SIG** \\
\hline \multicolumn{5}{|c|}{ Componentes dentoalveolares inferiores } \\
\hline$\overline{1-G o M e ~}$ & 37,35 & 40,50 & 0,002 & SIG** \\
\hline \multicolumn{5}{|c|}{ Componentes tegumentares } \\
\hline ANL & 117,38 & 107,90 & 0,004 & SIG** \\
\hline LI-E & 0,32 & 2,17 & 0,029 & SIG* $^{\star}$ \\
\hline
\end{tabular}

N/SIG: não significante

SIG*: significante $(p<0,05)$

SIG**: significante $(p<0,01)$ 


\begin{tabular}{|c|c|c|c|c|}
\hline \multirow{2}{*}{$\begin{array}{c}\text { Grandezas } \\
\text { Cefalométricas }\end{array}$} & \multicolumn{2}{|c|}{$\begin{array}{c}\text { Médias das } \\
\text { medidas finais }\end{array}$} & \multirow{2}{*}{\begin{tabular}{|c|} 
Tuckey \\
P
\end{tabular}} & \multirow[t]{2}{*}{ Significância } \\
\hline & $\begin{array}{c}\text { Grupo } \\
1\end{array}$ & $\begin{array}{c}\text { Grupo } \\
3\end{array}$ & & \\
\hline \multicolumn{5}{|c|}{ Componentes maxilares } \\
\hline SNA & 85,06 & 82,15 & 0,011 & SIG* \\
\hline \multicolumn{5}{|c|}{ Componentes mandibulares } \\
\hline SNB & 78,79 & 77,20 & 0,196 & N/SIG \\
\hline \multicolumn{5}{|c|}{ Componentes verticais } \\
\hline AFAI & 60,45 & 59,74 & 0,876 & N/SIG \\
\hline SN.GoMe & 34,43 & 33,16 & 0,563 & N/SIG \\
\hline PP.GoMe & 28,13 & 25,90 & 0,221 & $\mathrm{~N} / \mathrm{SIG}$ \\
\hline FRANK.GoMe & 27,28 & 24,28 & 0,014 & $\mathrm{SIG}^{\star}$ \\
\hline ArGo.GoMe & 49,63 & 51,08 & 0,546 & N/SIG \\
\hline \multicolumn{5}{|c|}{ Componentes dentoalveolares superiores } \\
\hline FHP-DISTAL 6 & 10,08 & 13,82 & 0,000 & SIG** \\
\hline FHP-ÁPICE 6 & 21,52 & 24,99 & 0,000 & $\mathrm{SIG}^{\star \star}$ \\
\hline 1-PP & 25,44 & 26,42 & 0,330 & N/SIG \\
\hline \multicolumn{5}{|c|}{ Componentes dentoalveolares inferiores } \\
\hline$\overline{1}$-GoMe & 37,35 & 37,81 & 0,858 & N/SIG \\
\hline \multicolumn{5}{|c|}{ Componentes tegumentares } \\
\hline ANL & 117,38 & 119,39 & 0,760 & N/SIG \\
\hline LI-E & 0,32 & $-0,82$ & 0,240 & $\mathrm{~N} / \mathrm{SIG}$ \\
\hline
\end{tabular}

N/SIG: não significante

SIG*: significante $(p<0,05)$

SIG**: significante $(p<0,01)$ 


\begin{tabular}{|c|c|c|c|c|}
\hline \multirow{2}{*}{$\begin{array}{c}\text { Grandezas } \\
\text { Cefalométricas }\end{array}$} & \multicolumn{2}{|c|}{$\begin{array}{c}\text { Médias das } \\
\text { medidas finais }\end{array}$} & \multirow{2}{*}{\begin{tabular}{c|} 
Tuckey \\
$P$
\end{tabular}} & \multirow[t]{2}{*}{ Significância } \\
\hline & $\begin{array}{c}\text { Grupo } \\
2\end{array}$ & $\begin{array}{c}\text { Grupo } \\
3\end{array}$ & & \\
\hline \multicolumn{5}{|c|}{ Componentes maxilares } \\
\hline SNA & 81,68 & 82,15 & 0,886 & N/SIG \\
\hline \multicolumn{5}{|c|}{ Componentes mandibulares } \\
\hline SNB & 75,59 & 77,20 & 0,183 & $\mathrm{~N} / \mathrm{SIG}$ \\
\hline \multicolumn{5}{|c|}{ Componentes verticais } \\
\hline AFAl & 65,56 & 59,74 & 0,001 & SIG** \\
\hline SN.GoMe & 40,77 & 33,16 & 0,000 & SIG** \\
\hline PP.GoMe & 33,75 & 25,90 & 0,000 & SIG** \\
\hline FRANK.GoMe & 31,78 & 24,28 & 0,000 & SIG** \\
\hline ArGo.GoMe & 46,44 & 51,08 & 0,003 & SIG** \\
\hline \multicolumn{5}{|c|}{ Componentes dentoalveolares superiores } \\
\hline FHP-DISTAL $\underline{6}$ & 10,67 & 13,82 & 0,001 & SIG** \\
\hline FHP-ÁPICE 6 & 21,97 & 24,99 & 0,001 & SIG** \\
\hline 1-PP & 28,76 & 26,42 & 0,003 & SIG** \\
\hline \multicolumn{5}{|c|}{ Componentes dentoalveolares inferiores } \\
\hline 1-GoMe & 40,50 & 37,81 & 0,008 & SIG** \\
\hline \multicolumn{5}{|c|}{ Componentes tegumentares } \\
\hline ANL & 107,90 & 119,39 & 0,000 & SIG** \\
\hline LI-E & 2,17 & $-0,82$ & 0,000 & SIG** \\
\hline
\end{tabular}

N/SIG: não significante

SIG*: significante $(p<0,05)$

SIG**: significante $(p<0,01)$ 